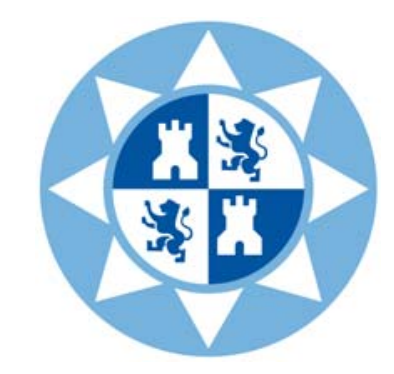

Universidad Politécnica de Cartagena Departamento de Ingeniería de los Alimentos y del Equipamiento Agrícola

\title{
Pomegranate (Punica granatum L.) response to different deficit irrigation conditions
}

Alejandro Galindo Egea 


\section{Pomegranate (Punica granatum L.) response to different deficit irrigation conditions}

\section{Alejandro Galindo Egea}

Agricultural Engineer

Supervisors: Alfonso Moriana Elvira

Arturo Torrecillas Melendreras

Thesis for the degree of Doctor (International Mention)

from the Polithecnic University of Cartagena 


\section{Doctoral Thesis Category}

This doctoral thesis corresponds to a compendium of publications category selected to qualify for Doctor (International Mention) degree from Polithecnic University of Cartagena.

To this end, the selected papers are indicated below:

- Rodríguez, P., Mellisho, C.D., Conejero, W., Ortuño, M.F., Cruz, Z.N., Galindo, A., Torrecillas, A. 2012. Plant water relations of leaves of pomegranate trees under different irrigation conditions. Environmental and Experimental Botany 77: 19-24.

- Galindo, A., Rodríguez, P., Collado-González, J., Cruz, Z.N., Torrecillas, E., Ondoño, S., Corell, M., Moriana, A., Torrecillas, A. 2014. Rainfall intensifies fruit peel cracking in water stressed pomegranate trees. Agricultural and Forest Meteorology 194: 29-35

- Galindo, A., Rodríguez, P., Mellisho, C.D., Torrecillas, E., Moriana, A., Cruz, Z.N., Conejero, W., Moreno, F., Torrecillas, A. 2013. Assessment of discretely measured indicators and maximum daily trunk shrinkage for detecting water stress in pomegranate trees. Agricultural and Forest Meteorology 180: 58-65.

- Mellisho, C.D., Egea, I., Galindo, A., Conejero, W., Rodríguez, P., Rodríguez, J., Romojaro, F., Torrecillas, A. 2012. Pomegranate (Punica granatum L.) fruit response to different deficit irrigation conditions. Agricultural Water Management 114: 30-36.

- Mena, P., Galindo, A., Collado-González, J., Ondoño, S., GarcíaViguera, C., Ferreres, F., Torrecillas, A., Gil-Izquierdo, A. 2013. Sustained deficit irrigation affects the colour and phytochemical characteristics of pomegranate juice. Journal of the Science of Food and Agriculture 93: 1922-1927.

- Galindo, A., Calín-Sánchez, A., Collado-González, J., Ondoño, S., Hernández, F., Torrecillas, A., Carbonell-Barrachina, A. 2014. Phytochemical and quality attributes of pomegranate fruits for juice consumption as affected by ripening stage and deficit irrigation. Journal of the Science of Food and Agriculture 94: 2259-2265. 
Eng. Alejandro Galindo Egea was funded by a grant of the FPU Fellowship Program from the Spanish government

This research was supported by projects Estrategias de manejo del riego deficitario para optimizar la calidad y saludabilidad del melocotón extratemprano y la granada (CICYT, AGL2010-19201-C04-01AGR), Nuevos criterios de riego deficitario en granado. Evaluación de la calidad y funcionalidad de productos hidrosostenibles y aceptación en el mercado nacional e internacional (CICYT, AGL2013-45922-C2-2-R) and Acciones para el fortalecimiento y consolidación de un grupo de investigación de excelencia en el INCA-UNAH (Cuba) sobre optimización del uso del agua en agricultura (AECID, D/016779/08, D/023231/09, D/030431/10, A1/035430/11). 


\section{Pomegranate (Punica granatum L.) response to different deficit irrigation conditions}

Thesis presented by Eng. Alejandro Galindo Egea to qualify for Doctor (International Mention) degree from Polithecnic University of Cartagena

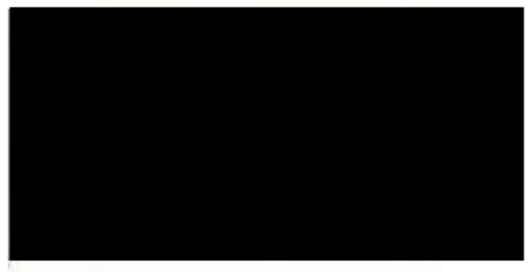

Alejandro Galindo Egea

Supervisors
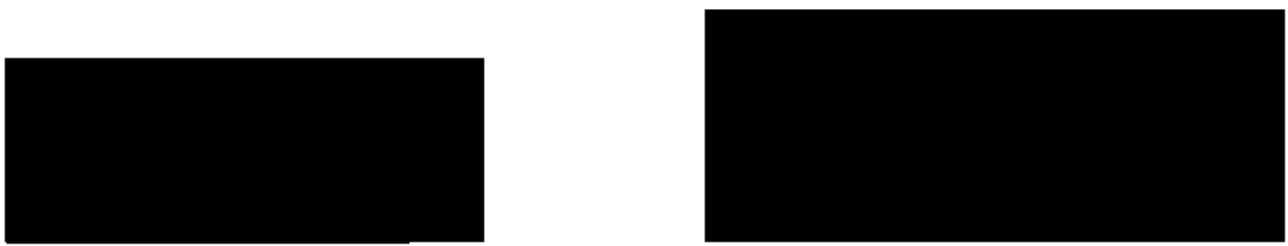

Alfonso Moriana Elvira

Arturo Torrecillas Melendreras Associate Profesor at US Research Professor at CSIC 


\section{CONFORMIDAD DE DEPÓSITO DE TESIS DOCTORAL POR LA COMISIÓN ACADÉMICA DEL PROGRAMA}

D. Francisco Artés Hernández, Presidente de la Comisión Académica del Programa Técnicas Avanzadas de Investigación y Desarrollo Agrario y Alimentario.

\section{INFORMA:}

Que la Tesis Doctoral titulada, "Pomegranate (Punica granatum L.) response to different deficit irrigation conditions", ha sido realizada, dentro del mencionado programa de doctorado, por D. Alejandro Galindo Egea, bajo la dirección y supervisión de los Drs. Alfonso Moriana Elvira y Arturo Torrecillas Melendreras.

En reunión de la Comisión Académica de fecha 16/02/2015, visto que en la misma se acreditan los indicios de calidad correspondientes y la autorización del Director de la misma, se acordó dar la conformidad, con la finalidad de que sea autorizado su depósito por la Comisión de Doctorado.

La Rama de conocimiento por la que esta tesis ha sido desarrollada es Ingeniería y Arquitectura

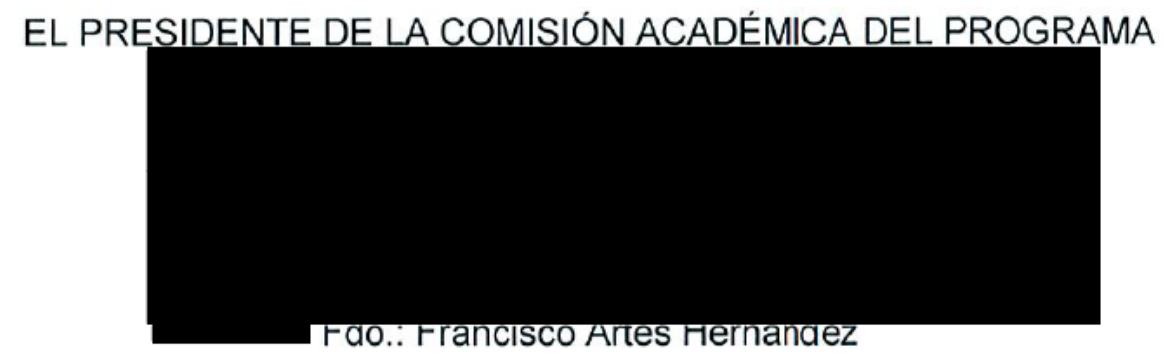

COMISIÓN DE DOCTORADO 


\section{Alejandro Galindo Egea}

Vistos los informes favorables de los Directores de Tesis y el $\mathrm{V}^{\circ} \mathrm{B}^{\circ}$ de la Comisión Académica para la presentación de la Tesis Doctoral titulada: "Pomegranate (Punica granatum L.) response to different deficit irrigation conditions" en la modalidad de "compendio de publicaciones" solicitada por D. Alejandro Galindo Egea, la Comisión de Doctorado de la Universidad Politécnica de Cartagena, en reunión celebrada el 27 de febrero de 2015, considerando lo dispuesto en el artículo 33 del Reglamento de Estudios Oficiales de Máster y Doctorado de la UPCT, aprobado en Consejo de Gobierno el 13 de abril de 2011 y modificado el 11 de julio de 2012,

\section{ACUERDA}

Autorizar la presentación de la Tesis Doctoral a D. Alejandro Galindo Egea en la modalidad de compendio de publicaciones.

Contra el presente acuerdo, que no agota la vía administrativa, podrá formular recurso de alzada ante el Sr. Rector-Magnífico de la Universidad Politécnica de Cartagena, en el plazo de un mes a partir de la notificación de la presente.

Cartagena, 27 de febrero de 2015

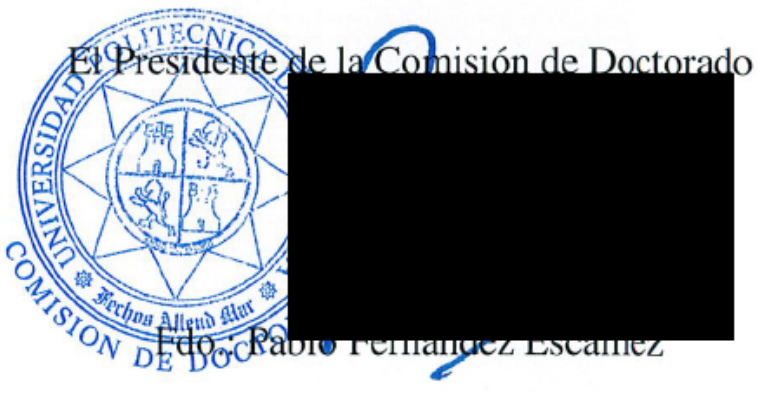




\section{Table of contents}

Page

1. Abbreviations and symbols

2. Scientific production during the predoctoral period

3. Abstract and Resumen

4. Introduction and objectives

5. Background

6. Publications

6.1. Plant water relations of leaves of pomegranate trees under different irrigation conditions

51

6.2. Rainfall intensifies fruit peel cracking in water stressed pomegranate trees

58

6.3. Assessment of discretely measured indicators and maximum daily trunk shrinkage for detecting water stress in pomegranate trees

6.4. Pomegranate (Punica granatum L.) fruit response to different deficit irrigation conditions

75

6.5. Sustained deficit irrigation affects the colour and phytochemical characteristics of pomegranate 83 juice

6.6. Phytochemical and quality attributes of pomegranate fruits for juice consumption as affected by ripening stage and deficit irrigation

7. Conclusions

8. Appendix 
1. Abbreviations and symbols 


\section{Abbreviations}

\begin{tabular}{|c|c|}
\hline CA & Citric acid \\
\hline $\mathrm{cv}$ & Cultivar \\
\hline DOY & Day of the year \\
\hline ED & Equatorial diameter \\
\hline ET & Evapotranspiration \\
\hline ETo & Crop reference evapotranspiration \\
\hline FW & Average fruit weight \\
\hline LVDT & Linear variable displacement transducer \\
\hline MA & Malic acid \\
\hline MC & Moisture content \\
\hline MDS & Maximum daily trunk shrinkage \\
\hline MI & Maturity index \\
\hline NF & Number of fruits \\
\hline PC & Peel content \\
\hline PG & Pomegranate \\
\hline PV & Pressure-Volume \\
\hline RWC & Relative water content \\
\hline SI & Signal intensity \\
\hline TA & Titratable acidity \\
\hline
\end{tabular}


TAC

TEAC

TF

TPC

TSS

\section{Symbols}

$a^{*}$

$\mathrm{ABTS}^{+}$

$b^{\star}$

$C^{*}$

g।

gleaf

glmd

$H^{\circ}$

$\mathrm{K}_{\mathrm{c}}$

$L^{*}$

$\mathrm{P}_{\mathrm{n}}$

$\mathrm{R}_{\mathrm{s}}$
Total anthocyanin content

Trolox equivalent antioxidant capacity

Total fruit yield

Total phenolic compounds

Total soluble solids
Red-greenness

Trolox equivalent antioxidant activity

Blue-yellowness

Chromaticity or chroma

Leaf conductance

Midday leaf conductance

Midday leaf conductance

Hue angle

Crop coefficient

Lightness

Net photosynthesis

Solar radiation 


\begin{tabular}{|c|c|}
\hline $\mathrm{RWC}_{\mathrm{a}}$ & Relative apoplastic water content \\
\hline $\mathrm{RWC}_{\mathrm{o}}$ & Relative water content at full content \\
\hline $\mathrm{RWC}_{\mathrm{tlp}}$ & Relative water content at the turgor loss point \\
\hline$T_{m}$ & Daily mean air temperature \\
\hline $\mathrm{VPD}_{\mathrm{m}}$ & Mean daily air vapour pressure deficit \\
\hline$\epsilon$ & $\begin{array}{l}\text { Leaf bulk modulus of elasticity of leaf tissue at } 100 \% \\
\text { relative water content }\end{array}$ \\
\hline$\Psi_{\text {fruit }}$ & Midday fruit water potential \\
\hline$\Psi_{1}$ & Leaf water potential \\
\hline$\Psi_{\text {leaf }}$ & Midday leaf water potential \\
\hline$\Psi_{\mathrm{md}}$ & Midday leaf water potential \\
\hline$\Psi_{\text {os }}$ & Leaf osmotic potential at full turgor \\
\hline$\Psi_{\mathrm{p} \text { arils }}$ & Midday fruit juice turgor potential \\
\hline$\Psi_{\mathrm{p} \text { leaf }}$ & Midday leaf turgor potential \\
\hline$\Psi_{\text {p peel }}$ & Fruit peel turgor potential \\
\hline$\Psi_{\mathrm{pd}}$ & Predawn leaf water potential \\
\hline$\Psi_{\mathrm{pmd}}$ & Midday leaf turgor potential \\
\hline$\Psi_{\mathrm{ppd}}$ & Predawn leaf turgor potential \\
\hline$\Psi_{\text {stem }}$ & Midday stem water potential \\
\hline$\Psi_{\text {stlp }}$ & Leaf osmotic potential at the turgor loss point \\
\hline
\end{tabular}


$\Psi_{\text {tlp }}$

$\Psi_{\pi}$ arils

$\Psi_{\text {T leaf }}$

$\Psi_{\pi \text { peel }}$

Leaf water potential at the turgor loss point

Fruit juice osmotic potential

Midday leaf osmotic potential

Fruit peel osmotic potential 


\section{Scientific production during the predoctoral period}




\subsection{Directly related with the PhD thesis}

\subsubsection{Papers in $\mathrm{SCl}$ journals}

Mellisho, C.D., Egea, I., Galindo, A., Conejero, W., Rodríguez, P., Rodríguez, J., Romojaro, F., Torrecillas, A. 2012. Pomegranate (Punica granatum L.) fruit response to different deficit irrigation conditions. Agricultural Water Management 114: 30-36.

Rodríguez, P., Mellisho, C.D., Conejero, W., Ortuño, M.F., Cruz, Z.N., Galindo, A., Torrecillas, A. 2012. Plant water relations of leaves of pomegranate trees under different irrigation conditions. Environmental and Experimental Botany 77: 19-24.

Mena, P., Galindo, A., Collado-González, J., Ondoño, S., García-Viguera, C., Ferreres, F., Torrecillas, A., Gil-Izquierdo, A. 2013. Sustained deficit irrigation affects the colour and phytochemical characteristics of pomegranate juice. Journal of the Science of Food and Agriculture 93: 1922-1927.

Galindo, A., Rodríguez, P., Mellisho, C.D., Torrecillas, E., Moriana, A., Cruz, Z.N., Conejero, W., Moreno, F., Torrecillas, A. 2013. Assessment of discretely measured indicators and maximum daily trunk shrinkage for detecting water stress in pomegranate trees. Agricultural and Forest Meteorology 180: 58-65.

Galindo, A., Rodríguez, P., Collado-González, J., Cruz, Z.N., Torrecillas, E., Ondoño, S., Corell, M., Moriana, A., Torrecillas, A. 2014. Rainfall intensifies fruit peel cracking in water stressed pomegranate trees. Agricultural and Forest Meteorology 194: 29-35

Galindo, A., Calín-Sánchez, A., Collado-González, J., Ondoño, S., Hernández, F., Torrecillas, A., Carbonell-Barrachina, A. 2014. Phytochemical and quality attributes of pomegranate fruits for juice consumption as affected by ripening stage and deficit irrigation. Journal of the Science of Food and Agriculture 94: 2259-2265.

Peña, M.E., Artés-Hernández, F., Aguayo, E., Martínez-Hernández, G.B., Galindo, A., Artés, F., Gómez, P.A. 2013. Effect of sustained deficit irrigation on physicochemical properties, bioactive compounds and postharvest life of pomegranate fruit (cv. 'Mollar de Elche'). Postharvest Biology and Technology. 86: 171-180.

Peña, M.E., Gómez, P.A., Artés, F., Aguayo, E., Martínez-Hernández, G.B., Otón, M., Galindo, A., Artés-Hernández, F. 2014. Quality changes of fresh-cut pomegranate arils during shelf life as affected by deficit irrigation and postharvest vapour treatments. Journal of the Science of Food and Agriculture (DOI: 10.1002/jsfa.6954). 


\subsubsection{Relevant participation at international congresses}

Rodríguez, P., Rodríguez, J., Cruz, Z. N., Dell'Amico, J. M., Jerez, E., Mellisho, C.D., Domínguez, C., Galindo, A., Conejero, W., Ortuño, M.F., Torrecillas, A. 2010. Respuestas del granado al déficit hídrico en la última fase de crecimiento de los frutos. XVII Congreso Científico Internacional del Instituto Nacional de Ciencias Agrícolas. San José de Las Lajas, La Habana (Cuba). p. 137.

Galindo, A., Cruz, Z.N., Mellisho, C.D., Rodríguez, P., Conejero, W., Ortuño, M.F., Torrecillas, A. 2011. Mecanismos de resistencia a la sequía en Punica granatum. II International Simposium on the Pomegranate. Madrid. p. 59.

Artés-Hernández., F, Aguayo, E., Artés, F., Galindo, A., Gómez, P.A. 2011. Postharvest quality of whole and fresh-cut pomegranates cultivated under deficit irrigation system. II International Conference on Quality Management of Fresh Cut Produce Convenience Food for a Tasteful Life. Torino (Italia)

Artés-Hernández., F, Aguayo, E., Artés, F., Galindo, A., Gómez, P.A. 2011. Evolución de los Polifenoles, la capacidad antioxidante y el color durante la conservación de granada cultivada bajo riego deficitario controlado. II International Simposium on the Pomegranate. Madrid.

Peña, M.E., Artés-Hernández, F., Galindo, A., Aguayo, E., Falagán, N., Artés, F., Gómez, P.A. 2012. Vitamin C, antioxidant activity and phenolics compounds of fresh-cut pomegranates cultivated under deficit irrigation strategy. VII International Postharvest Symposium. Kuala Lumpur (Malasia)

Peña, M.E., Artés-Hernández, F., Aguayo, E., Castillejo, N., Artés, F., Galindo, A., Gómez, P.A. 2012. Evolución de la calidad físico-química de granada mínimamente procesada en fresco cultivada bajo estrés hídrico y tratado con UV-C. Congreso Iberoamericano de Ciencias y Técnicas del Frío. Madrid

Mellisho, C.D., Egea, I., Galindo, A., Conejero, W., Rodriguez, P., Rodríguez, J., Romojaro, F., Torrecillas, A. 2012. Pomegranate (Punica granatum L.) fruit response to different deficit irrigation conditions. XI Simposio Hispano-Portugués de Relaciones Hídricas en las Plantas. Sevilla. p. 136.

Moreno, F., Moriana, A., Correll, M., Girón, I., Galindo, A., Torrecillas, A. 2013. Uso de sensores para el registro continuo del estado hídrico de árboles frutales y su aplicación en la programación del riego. Conferencia invitada al IV Seminario Internacional del Uso Racional del Agua (IV USRA). Universidad Sur Colombiana en Neiva (Colombia). 30 octubre - 2 noviembre 2013. 
Peña, M.E., Artés-Hernández, F., Aguayo, E., Artés, F., Galindo, A., Gómez, P.A. 2013. Production and physicochemical characterization of pomegranate grown under regulated deficit irrigation. VII Congreso Ibérico de Agroingeniería y Ciencias Hortícolas. Madrid

Galindo, A., Rodríguez, P., Ondoño, S., Collado-González, J., Moriana, A., Cruz, Z.N., Moreno, F., Torrecillas, A. 2014. Plant water status indicators for detecting water stress in pomegranate trees. En: Actas del III Workshop en Investigación Agroalimentaria. Editores: ArtésHernández, F., Egea-Cortines, M., Palop-Gómez, A., Bañón-Arias, S., Bielza, P. Editorial: Universidad Politécnica de Cartagena. ISBN: 97884-697-1358-7. Cartagena, Murcia, España. 163- 166.

\subsubsection{Relevant participation at national congresses}

Peña, M.E., Artés-Hernández, F., Aguayo, E., Artés, F., Galindo, A., Gómez, P.A. 2011. Evolución postcosecha del metabolismo y compuestos bioactivos de granada cultivada bajo estrés hídrico. VI Congreso Nacional de Ciencia y Tecnología de los Alimentos. Universidad Politécnica de Valencia (UPV). Valencia

Peña, M.E, Artés-Hernández, F. Aguayo, E. Artés, F., Galindo, A., Gómez, P.A. 2012. Evolución de la calidad físico-química y compuestos bioactivos de granada mínimamente procesada en fresco cultivada bajo estrés hídrico y tratada con UV-C. I Workshop en Investigación Agroalimentaria WiA12. Cartagena

Galindo, A. 2012. Respuesta del granado al riego deficitario. I Workshop en Investigación Agroalimentaria WiA12. Cartagena

Torrecillas, A. Moreno, F., Gil-Izquierdo, A., Girón, I.F., Galindo, A., Collado-González, J., Pérez-López, D., Moriana, A., Corell, M., Carbonell-Barrachina, A. Hernández, F. 2012. Optimización de la producción en frutales mediterráneos. VII Foro INIA. Adaptación a cambio climático en la producción frutícola de hueso y pepita. Lérida

Peña, M.E., Artés-Hernández, F., Aguayo, E., Artés, F., Galindo, A., Gómez, P.A. 2013. Efecto de la conservación frigorífica bajo atmosfera modificada en la calidad de granada mínimamente procesada en fresco y en sus principales compuestos bioactivos. II Workshop en Investigación Agroalimentaria - WiA13. Cartagena

Torrecillas, A., Moreno, F., Gil-Izquierdo, A., Carbonell-Barrachina, A.A., Moriana, A., Pérez-López, D., Corell, M., Hernández, F., Girón, I.F., Galindo, A., Collado-González, J. 2013. Optimización de la producción de frutales mediterráneos. XI Foro INIA. Adaptación al cambio climático en la producción de frutos cítricos y subtropicales. Valencia 


\subsection{Other related publications}

\subsubsection{Papers in $\mathrm{SCl}$ journals}

Conejero, W., Mellisho, C.D., Ortuño, M.F., Galindo, A., Pérez-Sarmiento, F., Torrecillas, A. 2011. Establishing maximum daily trunk shrinkage and midday stem water potential reference equations for irrigation scheduling of early maturing peach trees. Irrigation Science 29: 299309.

Cruz, Z.N., Rodríguez, P., Galindo, A., Torrecillas, E., Ondoño, S., Mellisho, C.D., Torrecillas, A. 2012. Leaf mechanisms for drought resistance in Zizyphus jujuba trees. Plant Science 197: 77-83.

Collado-González, J., Cruz, Z.N., Rodríguez, P., Galindo, A., Díaz-Baños, F.G., García de la Torre, J., Ferreres, F., Medina, S., Torrecillas, A., Gil-Izquierdo, A. 2013. Effect of water deficit and domestic storage on the procyanidin content, size and aggregation process in pear-jujube (Z. jujuba) fruits. Journal of Agricultural and Food Chemistry 61: 6187-6197.

Corell, M., Girón, I.F., Galindo, A., Torrecillas, A., Torres-Sánchez, PérezPastor, A., Moreno, F. Moriana, A. 2014. Using band dendrometers in irrigation scheduling. Influence of the location inside the tree and comparison with point dendrometer. Agricultural Water Management 142: $29-37$.

Collado-González, J., Cruz, Z.N., Medina, S., Mellisho, C.D., Rodríguez, P., Galindo, A., Egea, I., Romojaro, F., Ferreres, F., Torrecillas, A., Gil-Izquierdo, A. 2014. Effects of water deficit during maturation on amino acids and jujube fruit eating quality. Macedonian Journal of Chemistry and Chemical Engineering 33: 105-119.

Girón, I.F., Corell, M., Galindo, A., Torrecillas, E., Morales, D., Dell'Amico, J., Torrecillas, A., Moreno, F. Moriana, A. 2015. Changes in the physiological response between leaves and fruits during a moderate water stress in table olive trees. Agricultural Water Management 148: 280-286.

\subsubsection{Chapters in books}

Jiménez, A., Torrecillas, A., Sevilla, F., Ortuño, M.F., Conejero, W., Ferreres, F., Medina, S., Galindo, A., Gil-Izquierdo, A. 2012. Limeinduced iron chlorosis in citrus: diagnosis through physiological and metabolic evidences. In: Advances in Citrus Nutrition. (Srivastava, A.K., Ed.). Springer Dordrecht, Heidelberg, New York, London. P. 321331. ISBN 978-94-007-4170-6, ISBN 978-94-007-4171-3 (eBook), DOI 10.1007/978-94-007-4171-3 


\subsubsection{Relevant participation at international congresses}

Mellisho, C.D., Conejero, W., Ortuño, M.F., Moriana, A., Galindo, A., Moreno, F., Torrecillas, A. 2010. New tools for regulated deficit irrigation scheduling in early maturing peach trees. $X$ Simposium Hispano Portugués de Relaciones Hídricas en las Plantas. Cartagena (España). p. 67-70.

Galindo, A., Mellisho, C.D., Conejero, W., Ortuño, M.F., Cruz, Z.N., Rodríguez, P., Torrecillas, A. 2010. Maximum daily trunk shrinkage and stem water potential baselines for irrigation scheduling of early maturing peach trees. $X$ Simposium Hispano Portugués de Relaciones Hídricas en las Plantas. Cartagena (España). p. 71-74.

Rodríguez, P., Mellisho, C.D., Rodríguez, J., Cruz, Z.N., Galindo, A., Torrecillas, A. 2012. Mechanisms for drought resistance in early maturing cvar Flordastar peach trees. XVIII Congreso Científico Internacional del Instituto Nacional de Ciencias Agrícolas. San José de las Lajas, La Habana (Cuba). Poster.

Cruz, Z.N., Rodríguez, P., Galindo, A., Torrecillas, E., Ondoño, S., Mellisho, C.D., Torrecillas, A. 2012. Leaf mechanisms for drought resistance in Ziziphus jujuba trees. XVIII Congreso Científico Internacional del Instituto Nacional de Ciencias Agrícolas. San José de las Lajas, La Habana (Cuba). Poster.

Navarro-Rico, J., Artés-Hernández, F., Gómez, P.A., Otón, M., Galindo, A., Cruz, Z.N., Torrecillas, A., Artés, F. 2013. Quality changes of Chinese jujube from deficit irrigation stored in controlled atmosphere. XI International Controlled \& Modified Atmosphere Research Conference. Trani (Italia). Poster.

Cruz, Z.N., Rodríguez, P., Galindo, A., Pérez-López, D., ColladoGonzález, J., Ondoño, S.-, Moreno, F., Moriana, A., Torrecillas, A. 2014. Jujube fruit water relations during fruit maturation stage under different irrigation conditions. XII Portuguese-Spanish Symposium on Plant Water Relations. Water to Feed the World. Book of Abstract. Évora (Portugal). 30 September - 3 October 2014. p.16. 


\section{Abstract and Resumen}




\section{Abstract}

The purpose of the present thesis was to analyse several physiological and agronomical aspects of the response of pomegranate (Punica granatum) to different irrigation conditions. For this, it was studied i) the leaf and fruit resistance mechanisms developed in response to water stress and recovery, ii) the comparison of different plant water status indicators and iii) the ripening and different deficit irrigation conditions on physical and chemical characteristics of pomegranate fruits.

Pomegranate plants confront water stress by developing stress avoidance and stress tolerance mechanisms. From the time of deficit irrigation began to be applied, leaf conductance decreased in order to control water loss via transpiration and to avoid leaf turgor loss (stress avoidance mechanism). Close to the end of the stress period, when maximum stress levels had developed, active osmotic adjustment was triggered, contributing to the maintenance of leaf turgor (stress tolerance mechanism). Other drought tolerance characteristics commonly seen in xeromorphic plants were also observed, such as high relative apoplastic water content $(42-58 \%)$, which would contribute to the retention of water at low leaf water potentials.

During the end of fruit growth and ripening phases pomegranate fruit was clearly sensitive to water deficit and water could enter the fruits via the phloem rather than via the xylem. Despite this, plants under much more severe water stress levels than those reported in the literature were able to maintain leaf turgor. However, fruit turgor was lost at all water deficit levels studied, which induced a reduced expansion of fruits. When rainfall affected previously water stressed pomegranate plants an asymmetric increase in fruit turgor pressure took place, because aril turgor increased to a much greater extent than peel turgor, the pressure of the arils on the peel favouring cracking.

Maximum daily trunk shrinkage (MDS) was identified to be the most suitable plant-based indicator for irrigation scheduling in adult 
pomegranate trees, because its signal:noise ratio was higher than that for $\Psi_{\text {stem }}$ and $g_{1}$. MDS increased in response to water stress, but when the $\Psi_{\text {stem }}$ fell below -1.67 MPa, the MDS values decreased. For non-limiting water conditions, MDS could be predicted from mean daily air temperature $\left(T_{m}\right)$ through exponential equations fitted to pooled data across several seasons. First-order equations were also obtained by pooling data across several seasons to predict MDS from crop reference evapotranspiration (ETo), mean daily air vapour pressure deficit $\left(V P D_{m}\right), T_{m}$ and solar radiation $\left(R_{s}\right)$, but these should be used only within a certain range of values (ETo, 2.1-7.4 mm; VPD ${ }_{m}, 0.64-2.96 \mathrm{kPa} ; \mathrm{T}_{\mathrm{m}}, 12.1-28.3{ }^{\circ} \mathrm{C}$; Rs, 119.4-331.3 $\mathrm{Wm}^{-2}$ ). Hence, automated MDS measurements have the potential to be used in irrigation scheduling of pomegranate, and these values can be normalized to non-limiting water conditions by locally derived empirical relationships with meteorological variables.

During ripening the peel of pomegranate fruits changes to show higher luminosity and greater red saturation. Also, the colour of the arils changes to a more perceptible red colour as a consequence of the increasing total anthocyanin content. However, neither the intense red colour of the arils nor their total phenolic compounds content was correlated with the juice antioxidant capacity. Fruits from sustained deficit irrigation plants showed a decrease in fruit growth, leading to a lower final fruit size and lower total yield, and some physical and chemical changes which reflected earlier ripening. In contrast, a more pronounced water stress during the second half of the fruit growth phase was more critical for fruit size than for the chemical characteristics of the fruit, probably because under this situation carbon assimilation should be allocated to the synthesis of primary metabolites, which did not exceeded the amount used for fruit growth to the detriment of the synthesis of carbon-based secondary metabolites.

Pomegranate juices from trees grown under moderate and severe induced by sustained deficit irrigation were of lower quality and less rich in 
bioactive compounds than those from trees grown without water stress. From a nutritional point of view, this means that a reduction in irrigation can provide a dramatic decrease in levels of phenolic compounds, especially anthocyanins and punicalagins, and hence a lower visual attraction of the resulting fruit juice owing to its weak red colour.

Sustained deficit irrigation (33\% ETo) fruits exhibited similar bioactive quality than full irrigated fruits, but a darker and more intense garnet colour and a clear advance in the optimal harvest time by about 78 days. Late-pomegranate fruits were rich in phytochemicals and could be of great interest to the juice industry. Knowledge of these trends is important, especially to improve pomegranate juice quality and to contribute to the sustainability of pomegranate culture with respect to water, fertiliser and energy saving. 


\section{Resumen}

El presente trabajo de tesis se centra en el estudio de algunos aspectos agronómicos y fisiológicos de la respuesta del granado (Punica granatum) a diferentes condiciones de riego. A este fin se abordaron i) los mecanuismos desarrollados a nivel de fruto y hoja para afrontar situaciones de déficit hídrico, ii) la comparación de distintos indicadores del déficit hídrico y iii) el estudio del efecto de las condiciones de riego deficitario y la maduración sobre las características físicas y químicas de la granada.

El granado desarrolla mecanismos de tolerancia y evitación del estrés para afrontar situaciones de déficit hídrico. Desde el injicio del estrés se produce una significativa regulación estomática a fin de regular las pérdidas dee agua vía transpiración y evitar la pérdida de la turgencia celular (mecanismo de evitación del estrés). Cuando el estrés aumenta hasta niveles muy considerables tiene lugar la realización de ajuste osmótico a nivel foliar (mecanismo de tolerancia al estrés). Los altos niveles de agua apoplástica (42-58 \%) podrían contribuir a la retención de agua a bajos potenciales hídricos, constituyendo otro mecanismo frecuente en plantas xeromórficas.

Si bien el granado es capaz de resistir niveles de estrés hídrico mucho mayores que los indicados en la mayoría de artículos científicos, la granada es altamente sensible al déficit hídrico durante los periodos de final del crecimiento del fruto y la maduración, y el agua entra en el fruto vía floema más bien que vía xilema, pudiendo perder la turgencia en un amplio rango de niveles de estrés. Cuando tras un periodo de déficit hídrico acontecen lluvias considerables, se produce un incremento asimétrico de la turgencia, ya que la de los arilos aumenta en mucho mayor medida que la de la piel, por lo que la presión de los arilos favorece el agrietado de los frutos.

La máxima contracción diaria del tronco (MDS) es el indicador más adecuado para ser utilizado en la programación del riego en granados 
adultos, al presentar una relación señal:ruido mucho mayor que la encontrada en otros indicadores como el $\Psi_{\text {stem }}$ y la $g_{\text {I. }}$. A niveles de $\Psi_{\text {stem }}$ inferiores a $-1.67 \mathrm{MPa}$ los valores de la MDS en lugar de aumentar disminuyen. En condiciones no limitantes de agua en el suelo, los valores de la MDS pueden predecirse utilizando la temperatura media diaria $\left(T_{m}\right)$ por medio de ecuaciones exponenciales elaboradas con datos de varios años de cultivo. Ecuaciones de primer grado resulatan adecuadas para predecir la MDS utilizando datos la evapotranspiración del cultivo de referencia (ETo), los valores medios diarios del déficit de presión de vapor $\left(V_{P} D_{m}\right), T_{m}$ y radiación solar $\left(R_{s}\right)$, aunque estas deberían ser utilizadas sólo dentro de un cierto rango de valores (ETo, 2.1-7.4 mm; VPD $\mathrm{m}_{\text {, }}$ 0.64$2.96 \mathrm{kPa} ; \mathrm{T}_{\mathrm{m}}, 12.1-28.3{ }^{\circ} \mathrm{C}$; Rs, 119.4-331.3 $\mathrm{Wm}^{-2}$ ). Por tanto, la medidas automatizadas de la MDS son potencialmente utilizables para el riego de la granada, pudiéndose normalizar los valores obtenidos mediante el uso de relaciones empíricas con variables meteorológicas obtenidas a nivel local.

Durante el periodo de maduración, la piel de las granadas evoluciona hacia una mayor saturación del color rojo y una mayor luminosidad. Paralelamente, los arilos también evolucionan a un color rojo mucho más perceptible como consecuencia de la acumulación de antocianos. Resulta esencial subrayar que ni la intensidad de color rojo ni el nivel de fenoles totales se relaciona con la capacidad antioxidante. Los frutos obtenidos con riego deficitario son de menor tamaño, aunque más maduros como demuestran algunos cambios físicos y químicos. Si durante el final del crecimiento del fruto acontecen niveles considerables de déficit hídrico, el tamaño del fruto resulta más afectado que sus características químicas, posiblemente porque bajo estas circunstancias la asimilación de carbono se destina en su totalidad a la síntesis de metabolitos primarios en detrimento de la síntesis de metabolitos secundarios no nitrogenados.

El zumo de granada procedente de árboles regados deficitariamente durante toda la estación son de menor calidad que el procedente de 
árboles bien regados, debido a un color menos rojizo y menor contenido en sustancias bioactivas, fundamentalmente antocianos y punicalaginas. Además, el riego deficitario sostenido durante toda la estación permite un adelanto de la maduración de unos 7-8 días. Las granadas tardías son muy ricas en sustancias bioactivas, pudiendo ser de alto valor para la industria, ya que su uso permitiría la mejora de la calidad del zumo. 
4. Introduction and objectives 
Spanish Mediterranean agrosystems are characterized by the aridity of the climate and the persistent shortage and low quality of the available water resources. Moreover, recent years have seen growing competition for the water that is available due to the expansion of industrial activity, the spread of new urban, tourist and recreational areas and the indispensable environment preservation measures. Collins et al. (2009) indicated that during the last thirty years drought periods have hit $17 \%$ of European territory, affecting $11 \%$ of the population, and have caused losses of $€ 100$ billion.

Consequently, the fact that Mediterranean agrosystems must face up to the need to cope with water scarcity cannot be questioned because any policy of continuous expansion of the supply is unsustainable (Pereira et al., 2002). In this sense, fruit culture in arid and semiarid areas must be directed towards the use of less water-demanding and more stressresistant plant materials which, together with deficit irrigation, will allow significant water savings and the profitable production of fruits.

Pomegranate (Punica granatum L.) despite being grown commercially in many regions of the world, including countries of the Mediterranean Basin (Stover and Mercure, 2007; Holland, et al., 2009) and being one of the oldest known edible fruits (Blumenfeld et al., 2000), it has frequently been considered a minor crop. Nonetheless, this is beginning to change and there is a growing interest in the consumption of pomegranate for their organoleptic characteristics and their perceived health benefits (Sumner et al., 2005; Lansky and Newman, 2007).

This crop is considered to be drought-resistant because it supports heat and can thrives well in arid and semiarid areas, even under desert conditions (Aseri et al., 2008). Nevertheless, no information exists neither on the mechanisms developed by pomegranate trees to confront drought at leaf level nor at fruit level. These aspects are of paramount importance because of to reach optimal growth, yield and fruit quality for commercial production the crop requires optimum plant water status (Prasad et al., 2003; Shaliendra and Narendra, 2005; Sulochanamma et al., 2005; Levin, 
2006). Moreover, one of the foremost physiological disorders is the cracking of ripe fruit (Blumenfeld et al., 2000; Holland et al., 2009), which has a severe economic impact on pomegranate fruit value, seems to be related to fruit water status (Prasad et al., 2003).

Studies on the pomegranate response to irrigation, crop water requirements and irrigation scheduling are very scarce in plants under field conditions. In this sense, Intrigliolo et al. (2011a,b, 2013) suggested preliminary irrigation recommendations for pomegranate trees and Bhantana and Lazarovitch (2010) measured the evapotranspiration (ET), crop coefficients $(\mathrm{Kc})$ and growth in two young pomegranate tree cultivars grown in lysimeters to varying electrical conductivity of the irrigation water. Their results indicated that salinity had a significant effect on both daily ET and total ET and that the calculated value of $\mathrm{Kc}$ is applicable for irrigation scheduling in young pomegranate orchards using irrigation water with various salinities.

Because plants are in the middle of the soil-plant-atmosphere continuum, the use of plant-based water status indicators has become very popular for planning precise irrigation. Since plant water status controls many physiological processes and crop productivity, this information can be highly useful in irrigation scheduling (Fernández and Cuevas, 2010; Ortuño et al., 2010). Measurements of trunk diameter fluctuations using LVDT (linear variable differential transducer) sensors provide continuous and automated recording of maximum daily trunk shrinkage (MDS), which has been shown to be suitable for the development of automated irrigation scheduling in fruit trees (Conejero et al., 2007; Ortuño et al., 2009a,b; Moriana et al., 2010). Absolute water stress indicator values recorded without considering the evaporative demand might be meaningless. For this reason, it is better to use the concept of signal intensity (SI) for irrigation scheduling, normalizing an indicator's absolute values with respect to values under non limiting soil water conditions (Naor and Cohen, 2003; Goldhamer and Fereres, 2001; Ortuño et al., 2005, 2006). Under operational irrigation scheduling, plant 
water status indicators for non-limiting conditions, needed for SI calculation, could be derived from previously established relationships with meteorological variables.

Intrigliolo et al. (2011b) suggested (i) differences in pomegranate water status could be detected earlier for midday stem water potential ( $\left.\Psi_{\text {stem}}\right)$ than for MDS, (ii) a significant, but relatively low, correlation between MDS and crop reference evapotranspiration (ETo), whereas the relationships between MDS and air temperature and air vapour pressure deficit were even weaker, and (iii) the best fit between MDS and $\Psi_{\text {stem }}$ was obtained with a linear regression, which changed with fruit growth pattern or fruit removal. This behavior was different from that of other fruit trees. For example, (i) MDS has been frequently found more sensitive than the other indicators in detecting plant water stress (Ortuño et al., 2010), (ii) some authors have shown that it is possible to predict adequately MDS reference values in crop trees with daily meteorological variables (Moreno et al., 2006; Ortuño et al., 2009a; Conejero et al., 2011), and (iii) Ortuño et al. (2010) indicated that in several fruit tree species under drought stress the decrease in $\Psi_{\text {stem }}$ is associated with an increase in MDS, but this pattern changes at values below a $\Psi_{\text {stem }}$ threshold and any further reduction in $\Psi_{\text {stem }}$ is associated with a decrease in MDS values.

Fruit trees are highly sensitive to drought stress at particular phenological stages, such as fruit growth (Berman and DeJong, 1997; Xiloyannis et al., 2005), which in pomegranate trees occurs mainly during July and August (Melgarejo et al., 1997; Intrigliolo et al., 2011a,b). In citrus plants, Domingo et al. (1996) showed that deficit irrigation during linear fruit growth induces a reduction in yield due to smaller fruit size at harvest. In contrast, although water deficit during the final stage of rapid fruit growth in stone fruit trees produces a decrease in final fruit size, beneficial aspects include increased total fruit soluble solids levels and earlier fruit ripening (Crisosto et al., 1994; Torrecillas et al., 2000; Besset et al., 2001). 
According to Borochov-Neori et al. (2009), pomegranate consumer satisfaction and producer profitability require that the fruit excel in two aspects-health-related quality (antioxidative capacity) and fruit attractiveness (mainly colour and the taste of the arils and their juice). In this sense, the level of chemical and antioxidant compounds in pomegranate juice has been studied during fruit development and maturation (Gil et al., 1996; Kulkarni and Aradhya, 2005), in different environmental and cultivation conditions (Gil et al., 1995; Holland et al., 2009), and between cultivars (Melgarejo et al., 2000; Tzulker et al., 2007; Ozgen et al., 2008; Borochov-Neori et al., 2009). However, and in spite of the paramount importance of increasing water shortage in the most suitable regions for pomegranate growth hardly any reports exist on the effect of irrigation management on pomegranate fruit yield and quality. An exception is the work of Sonawane and Desai (1989), who indicated that by applying different irrigation regimes it is possible to control the desired time of fruit yield in pomegranates, while other authors have showed that irrigation has a positive effect on vegetative growth, yield and fruit weight (Prasad et al., 2003; Shaliendra and Narendra, 2005; Sulochanamma et al., 2005).

For these reasons, the overall objective of the present study aimed deep in the knowledge of the pomegranate (Punica granatum) response to different irrigation conditions. For this goal, the following partial objectives were addressed:

- To investigate plant water relations in adult pomegranate trees under field conditions, in order to establish the stress avoidance and stress tolerance mechanisms developed in response to water stress and recovery.

- To increase the knowledge of the relationship between leaf and fruit water relations under different water deficit levels during the end of fruit growth and ripening phases in order to stablish the causes and mechanisms of fruit peel cracking. 
- To stablish, the sensitivity of MDS in comparison with other discretely measured indicators of plant water status in response to water deficit and recovery.

- To study the feasibility of obtaining reference equations for tree water status indicators in trees under non-limiting water conditions and their intra and inter-seasonal constancy was also investigated.

- To examine effect of different deficit irrigation conditions on the physical and chemical characteristics of pomegranate fruits. 


\section{References}

Aseri, G.K., Jain, N., Panwar, J., Rao, A.V., Meghwal, P.R., 2008. Biofertilizers improve plant growth, fruit yield, nutrition, metabolism and rhizosphere enzyme activi- ties of Pomegranate (Punica granatum L.) in Indian Thar Desert. Sci. Hortic. 117, 130-135.

Berman, M.E., DeJong, T.M., 1997. Crop load and water stress on daily stem growth in peach (Prunus persica). Tree Physiology 17, 467-472.

Besset, J., Génard, M., Girard, T., Serra, V., Bussi, C., 2001. Effect of water stress applied during the final stage of rapid growth of peach trees (cv. Big-Top). Sci. Hortic. 91, 289-303.

Bhantana, P., Lazarovitch, N., 2010. Evapotranspiration crop coefficient and growth of two young pomegranate (Punica granatum L.) varieties under salt stress. Agric. Water Manage. 97, 715-722.

Blumenfeld, A., Shaya, F., Hillel, R., 2000. Cultivation of pomegranate. In: Options Méditerranées. CIHEAM http://ressources.ciheam.org/om/pdf/ a42/00600264.pdf

Borochov-Neori, H., Judeinstein, S., Tripler, E., Harari, M., Greenberg, A., Shomer, I., Holland, D., 2009. Seasonal and cultivar variations in antioxidant and sensory quality of pomegranate (Punica granatum L.) fruit. Journal of Food Composition and Analysis 22, 189-195.

Collins, R., Kristensen, P., Thyssen, N., 2009. Water Resources Across Europe-Confronting Water Scarcity and Drought. European Environment Agency, Copenhagen, 57pp.

Conejero, W., Alarcón, J.J., García-Orellana, Y., Nicolás, E., Torrecillas, A., 2007. Evaluation of sapflowand trunk diameter sensors used for irrigation scheduling in early maturing peach trees. Tree Physiol. 27, 1753-1759. 
Conejero, W., Mellisho, C.D., Ortuño, M.F., Galindo, A., Pérez-Sarmiento, F., Torrecillas, A., 2011. Establishing maximum daily trunk shrinkage and midday stem water potential reference equations for irrigation scheduling of early maturing peach trees. Irrig. Sci. 29, 299-309.

Crisosto, C.H., Johnson, R.S., Luza, J.G., Crisosto, S.M., 1994. Irrigation regimes affect fruit soluble solids concentration and rate of water loss of 'O'Henry' peaches. HortScience 29, 1169-1171.

Domingo, R., Ruiz-Sánchez, M.C., Sánchez-Blanco, M.J., Torrecillas, A., 1996. Water relations, growth and yield of Fino lemon trees under regulated deficit irrigation. Irrig. Sci. 16, 115-123.

Fernández, J.E., Cuevas, M.V., 2010. Irrigation scheduling from stem diameter variations: a review. Agric. For. Meteorol. 150, 135-151.

Gil, M.I., Cherif, J., Ayed, N., Artés, F., Tomás-Barberán, F.A., 1995. Influence of cultivar, maturity stage and geographical location on the juice pigmentation of Tunisian pomegranates. Zeitschrift Fur Lebensmittel-Untersuchung Und-Forschung 201, 361-364.

Gil, M.I., Sánchez, R., Marín, J., Artés, F., 1996. Quality changes in pomegranate during ripening and cold storage. Zeitschrift Fur Lebensmittel-Untersuchung Und-Forschung 202, 481-485.

Goldhamer, D.A., Fereres, E., 2001. Irrigation scheduling protocols using continu- ously recorded trunk diameter measurements. Irrig. Sci. 20, $115-125$.

Holland, D., Hatib, K., Bar-Yàakov, I., 2009. Pomegranate: botany, horticulture, breeding. Hortic. Rev. 35, 127-191.

Intrigliolo, D.S., Bonet, L., Nortes, P.A., Puerto, H., Nicolás, E., Bartual, J., 2013. Pomegranate tres performance under sustained and regulated deficit irrigation. Irrig. Sci. 31, 959-970. 
Intrigliolo, D.S., Nicolás, E., Bonet, L., Ferrer, P., Alarcón, J.J., Bartual, J., 2011a. Water relations of field grown pomegranate trees (Punica granatum) under different drip irrigation regimes. Agric. Water Manage. 98, 691-696.

Intrigliolo, D.S., Puerto, H., Bonet, L., Alarcón, J.J., Nicolás, E., Bartual, J., 2011b. Usefulness of trunk diameter variations as a continuous water stress indicators of pomegranate (Punica granatum) trees. Agric. Water Manage. 98, 1462-1468.

Kulkarni, A.P., Aradhya, S.M., 2005. Chemical changes and antioxidant activ- ity in pomegranate arils during fruit development. Food Chem. 93, 319-324.

Lansky, E.P., Newman, R.A., 2007. Punica granatum (pomegranate) and its potential for prevention and treatment of inflammation and cancer. Journal of Ethnopharmacology 109, 177-206.

Levin, G.M., 2006. In: Bare, B.L. (Ed.), Pomegranate roads: a soviet botanist's exile from Eden, vol. 1. Floreat Press, Forestville, pp. 5-183.

Melgarejo, P., Martínez-Valero, R., Guillamón, J.M., Miró, M., Amorós, A., 1997. Phenological stages of the pomegranate tree (Punica granatum L.). Annals of Applied Biology 130, 135-140.

Melgarejo, P., Salazar, D.M., Artés, F., 2000. Organics acids and sugar composition of harvested pomegranate fruits. European Food Research and Technology 211, 185-190.

Moreno, F., Conejero, W., Martín-Palomo, M.J., Girón, I.F., Torrecillas, A., 2006. Maximum daily trunk shrinkage reference values for irrigation scheduling in olive trees. Agric. Water Manage. 84, 290-294.

Moriana, A., Girón, I.F., Martín-Palomo, M.J., Conejero, W., Ortuño, M.F., Torrecillas, A., Moreno, F. 2010. New approach for olive trees 
irrigation scheduling using trunk diameter sensors. Agric. Water Manag. 97, 1822-1828.

Naor, A., Cohen, S., 2003. Sensitivity and variability of maximum trunk shrinkage midday stem water potential, and transpiration rate in response to withholding irrigation from field grown apple trees. HortScience. 38, 547-551.

Ortuño, M.F., Alarcón, J,J., Nicolás, E., Torrecillas, A. 2005. Sap flow and trunk diameter fluctuations of young lemon trees under water stress and rewatering. Environ. Exp. Bot. 54: 155-162.

Ortuño, M.F., Brito, J.J., García-Orellana, Y., Conejero, W., Torrecillas, A., 2009a. Maximum daily trunk shrinkage and stem water potential baselines for irrigation scheduling of lemon trees. Irrig. Sci. 27, 121127.

Ortuño, M.F., Conejero, W., Moreno, F., Moriana, A., Intrigliolo, D.S., Biel, C., Mellisho, C.D., Pérez-Pastor, A., Domingo, R., Ruiz-Sánchez, M.C., Casadeus, J., Bonany, J., Torrecillas, A. 2010. Could trunk diameter sensors be used in Woody crops for irrigation scheduling? A review of current knowledge and future perspectives. Agric. Water Manage. 97, 1-11.

Ortuño, M.F., García-Orellana, Y., Conejero, W., Pérez-Sarmiento, F., Torrecillas, A. 2009b. Assessment of maximum daily trunk shrinkage signal intensity threshold values for deficit irrigation in lemon trees. Agric. Water Manage. 96, 80-86.

Ortuño, M.F., García-Orellana, Y., Conejero, W., Ruiz-Sánchez, M.C., Alarcón, J.J., Torrecillas, A. 2006. Stem and leaf water potentials, gas exchange, sap flow, and trunk diameter fluctuations for detecting water stress in lemon trees. Trees - Struct. Funct. 20, 1-8. 
Ozgen, M., Durgaç, C., Serçe, S., Kaya, C., 2008. Chemical and antioxidant properties of pomegranate cultivars grown in the Mediterranean region of Turkey. Food Chem. 111, 703-706.

Pereira, L.S., Cordery, I., lacovides, I., 2002. Coping with Water Scarcity. Technical Documents in Hydrology, vol. 58. UNESCO, Paris.

Prasad, R.N., Bankar, G.J., Vashishtha, B.B., 2003. Effect of drip irrigation on growth, yield and quality of pomegranate in arid region. Indian $\mathrm{J}$. Hortic. 60, 140-142.

Shaliendra, A., Narendra, A., 2005. The effect of trickle irrigation on growth, yield and quality of pomegranate (Punica granatum) cv. Ganesh in Chhattisgarh region. Mysore J. Agr. Sci. 39, 175-181.

Sonawane, P.C., Desai, U.T., 1989. Performance of staggered cropping in pomegranate. Journal of Maharashtra Agricultural Universities 14, 341-342.

Stover, E., Mercure, E.W., 2007. The Pomegranate: a new look at the fruit of paradise. HortScience 42, 1088-1092.

Sulochanamma, B.N., Yellamanda Reddy, T., Subbi Reddy, G., 2005. Effect of basin and drip irrigation on growth, yield and water use efficiency in pomegranate cv Gennesh. Acta Hortic. 696, 277-279

Sumner, M.D., Elliott-Eller, M., Weidner, G., Daubenmier, J.J., Chew, M.H., Marlin, R., Raisin, C.J., Ornish, D., 2005. Effect of pomegranate juice consumption on mycocardial perfusion in patient with coronary heart disease. Am. J. Cardiol. 96, 810-814.

Torrecillas, a., Domingo, R., Galego, R., Ruiz-Sánchez, M.C., 2000. Apricot tree response to withholding irrigation at different phenological periods. Sci. Hortic.-Amsterdam. 85, 201-215 
Tzulker, R., Glazer, I., Bar-Ilan, I., Holland, D., Aviram, M., Amir, R., 2007. Antioxidant activity, polyphenol content, and related compounds in different fruit juices and homogenates prepared from 29 different pomegranate accessions. Journal of Agricultural and Food Chemistry 55, 9559-9570.

Xiloyannis, C., Massai, R., Dichio, B., 2005. L'acqua e la tecnica dell'irrigazione. In: Fideghelli, C., Sansavini, S. (Eds.), II Pesco. Edagricole, Bologna, pp. 145-171. 
5. Background 


\subsection{Origin, taxonomy and morphology}

Pomegranate (Punica granatum L.) (Figure 5.1) belongs to the family Punicaceae, which only has the Punica genus, and is one of the earliest domesticated plant species (Neolitic era) and its fruit is one of the oldest known edible fruits (Font Quer, 1959; Levin, 2006; Still, 2006; Melgarejo, 2010). The fruit was mentioned in the Bible as one of the seven kinds which Israel was blessed with (Blumenfeld et al., 2000). The generic name Punica refers to Pheonicia (Carthage), probably because the Phoenicians or the Carthaginians brought this crop to southern Europe, and granatum, full of grains, in allusion to the multiple seeds that the fruit contains. Moreover, pomegranate follows the Latin name of the fruit Malum granatum, which means granny apple (Holland et al. 2009).

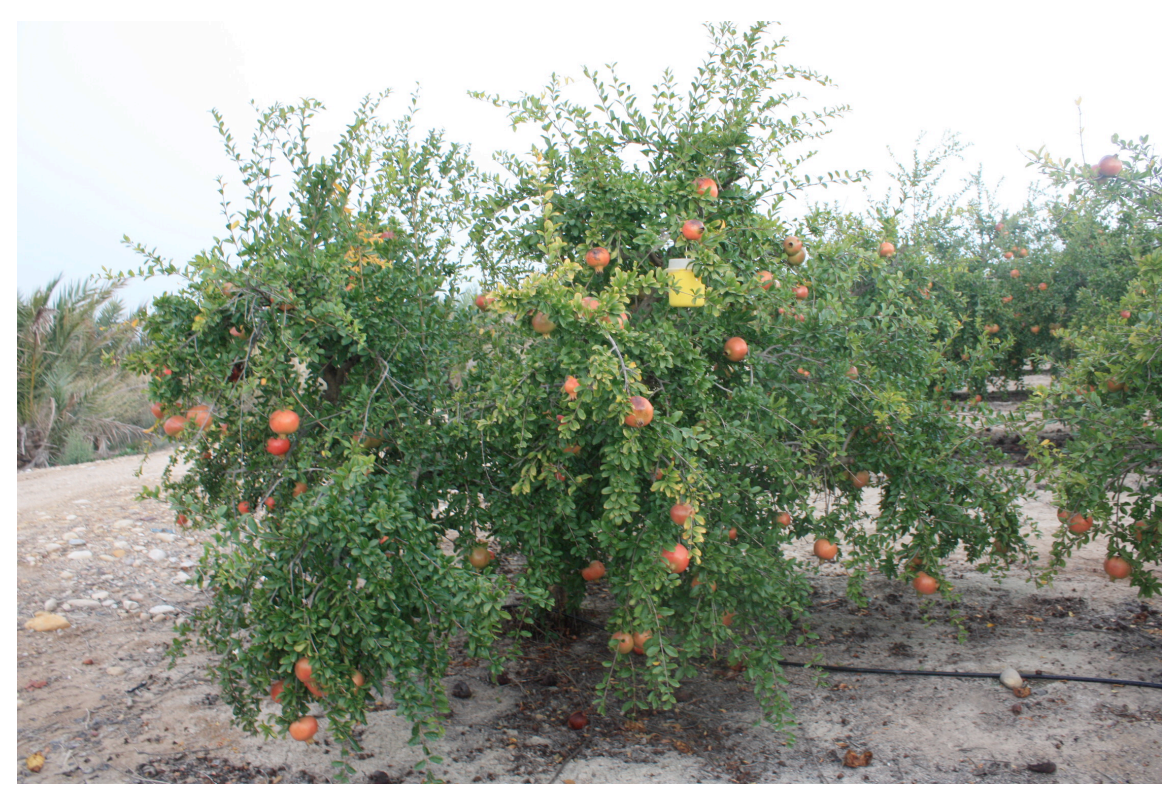

Figure 5.1. Pomegranate (Punica granatum L. cv Mollar de Elche) tree

P. granatum is believed to be a native to the southern Caspian belt (Iran) and northern Turkey (Janick, 2007). According to Melgarejo (2010) some authors also included $P$. nana, a species with non-edible fruits, in 
the genus Punica. In contrast, others (Zukvskij, 1950; Guarino et al., 1990) indicate that $P$. protopunica, an endemic of the Socotra Island (Yemen), is the ancestral of the genus (Shilkina, 1973) and the only congeneric relative of $P$. granatum species at present cultivated (Levin, 2006). Pomegranates were subsequent introduced throughout the rest of Asia to the Mediterranean to North Africa and to Europe. Spanish sailors brought them to the New World and the Spanish Jesuit missionaries introduced them into Mexico and California (Goor and Liberman, 1956; Morton, 1987). At present, pomegranate is cultivated throughout the world in tropical and subtropical areas in many different microclimatic zones, the optimal growth conditions being Mediterranean-like climates (Holland et al., 2009).

Domesticated pomegranate is a small tree that grows up to $5 \mathrm{~m}$, tending to develop multiple trunks and have a bushy appearance. To establish new trees the use of rootstocks with pomegranate is not a common practice. In order to ensure adequate uniformity and successful establishment of the trees, planting potted nursery trees is the preferred practice. Pomegranate is a deciduous tree, but there are several evergreen cultivars in India (Sharma and Dhilom, 2002; Singh et al., 2006). The tree is much-branched, more or less spiny and the bark colour depends on the cultivar, darkening and tending to split as the tree matures. The leaves have an oblanceolate shape with an obtuse apex an acuminate base, which are green when they mature and tend to have a reddish colour when young. Leaves are also characterized by short petioles and for being smooth and hairless (Holland et al., 2009).

Flowering occurs mainly in April-May and may continue until the end of summer (Figure 5.2). Flowers can appear solitary, in pairs, or in clusters. Melgarejo et al. (1997) describing the phenological stages of the Mollar de Elche pomegranate tree, indicated that flower buds appear among the leaves on shoots, being greenish at first, but becoming red after a few days. The sepals are visible and close together. When buds increase in size, becoming pear-shaped, the differences between male 
and hermaphrodite flowers becomes apparent both in the shape and colour of the calyx. Later, the sepals open to show the folded red petals inside, and toward the end of this stage, petals unfold and the pistil anthers become visible. Pomegranate flowers develop into one or two types of flowers: hermaphrodite flowers (vase shaped) and male flowers (bell shaped), the male flowers being infertile due to a poorly developed or no pistil and atrophied ovaries containing few ovules. When the calyx opens totally the petals are purple and seem to be inserted between every two sepals, giving the impression of alternating petals and sepals. The anthers of the stamen change to deep yellow when pollen is ripe.
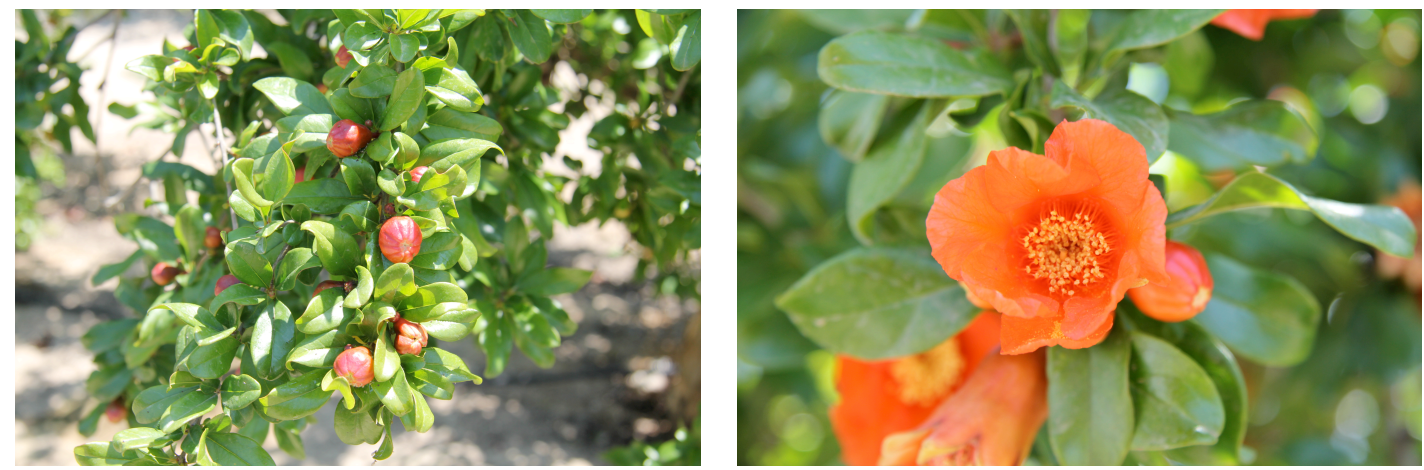

Figure 5.2. Pomegranate flower buds (left) and open flower (right).

When fertilization takes place the ovary grows rapidly and the colour turns from greenish brown to green. Pomegranate fruits are complex in structure, showing a persistent calyx at the top of fruit, which is maintained until maturity and acts as a distinctive feature of these fruits. The fruit is technically a leathery-skinned and fleshy berry. The multi-ovule chambers (locules) are separated by membranous walls (septum) and fleshy mesocarp (Holland et al., 2009). The locules are filled with many seeds (arils) which comprise the edible portion of the fruit. The arils contain a juicy edible layer that develops entirely from the outer epidermal cells of the seed, which elongate to a very large extent in a radial direction 
(Fahan, 1976). The sap of these cells develops a turgor pressure that preserves the characteristic external shape of the same (Holland et al., 2009). The husk is composed of two parts: the pericarp, which provides a cuticle layer and fibrous mat; and the mesocarp (also known as the albedo), which is the spongy tissue and inner fruit wall to which the arils are attached (Stover and Mercure, 2007).

During fruit ripening fleshy seeds change from white to pinkish-red or red and the peel of the fruit changes from green to greenish yellow, and finally to brownish-yellow with reddish patches. The colour of the edible juice can vary from white to deep red, depending on the variety. There is no correlation between the outer skin colour of the rind and the colour of the arils. Fruits ripen 5 to 8 months after fruit set and the peel colour does not indicate the ripening degree of the fruit because it attains its final colour long before the arils are fully ripened (Holland et al., 2009).
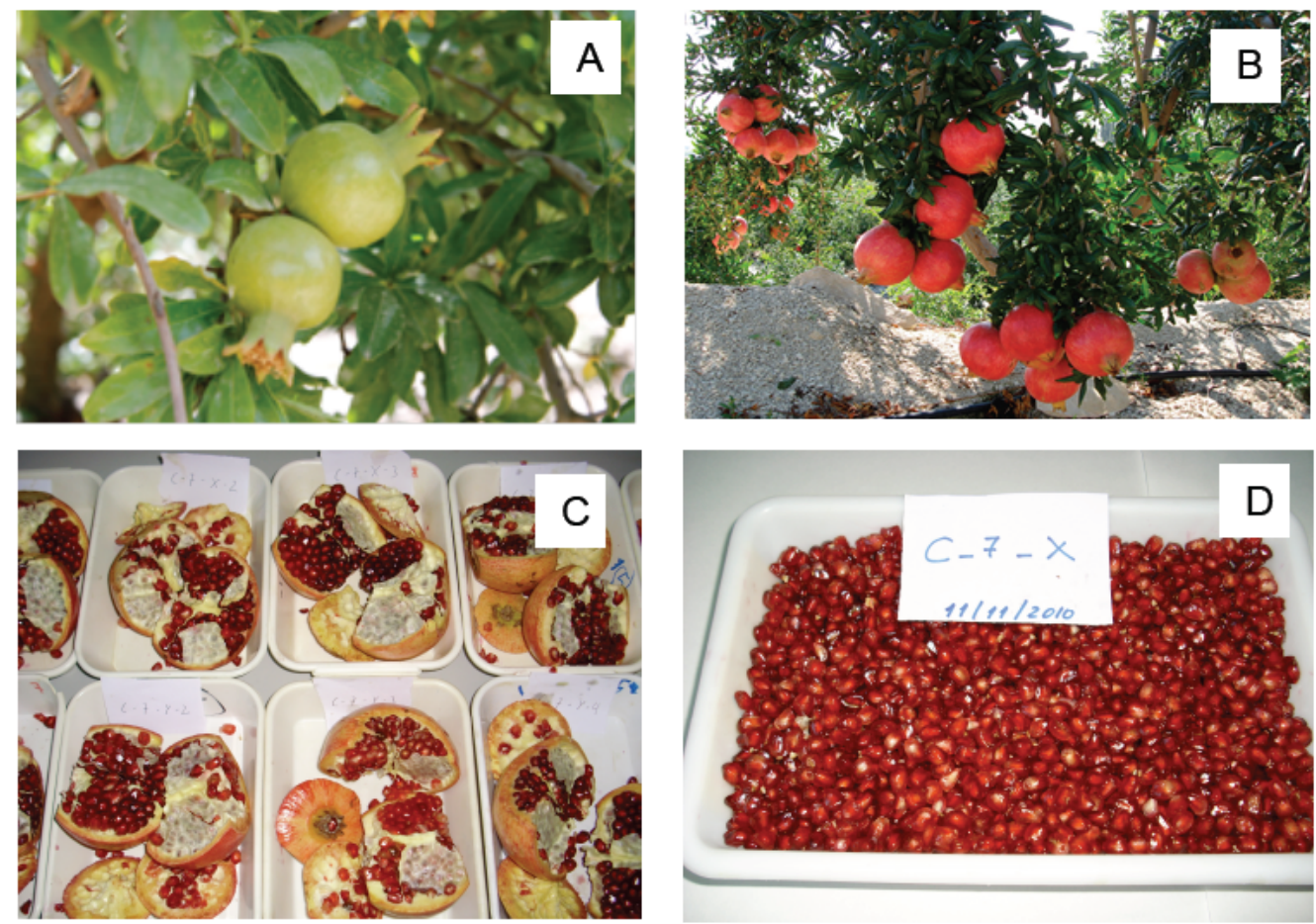

Figure 5.3. Pomegranate fruits (cv Mollar) (A and B), locules separated by septum (C) and arils (D) 


\subsection{Spanish cultivars}

Pomegranate cultivars have been reported in many places all over the world. It is probable that some of these cultivars acquired different names in different countries but are the same basic genotype, due to the spread of pomegranate throughout different regions and continents. Frequently, cultivar selections reflect different fruit characteristics that may be favoured by different cultures. For example, in India most people dislike acidic fruit, while people from western European countries prefer sweetsour cultivars, such as Wonderful. In general, fruits from sour and soursweet cultivars have a higher citric acid content than malic acid content, while fruits from sweet cultivar have similar contents (Mena et al., 2011; Carbonell-Barrachina et al., 2012).

In Spain, two groups of cultivars (Mollar and Valenciana) have been cultivated traditionally (Figures 5.1, 5.2 and 5.4), even though there are other interesting cultivars, such as Albar de Blanca, Agridulce de Ojós, Borde de Albatera, Borde de Ojós, Casta del reino, Piñón tierno de Ojós, etc. (Melgarejo et al., 2010; Martínez et al., 2012).
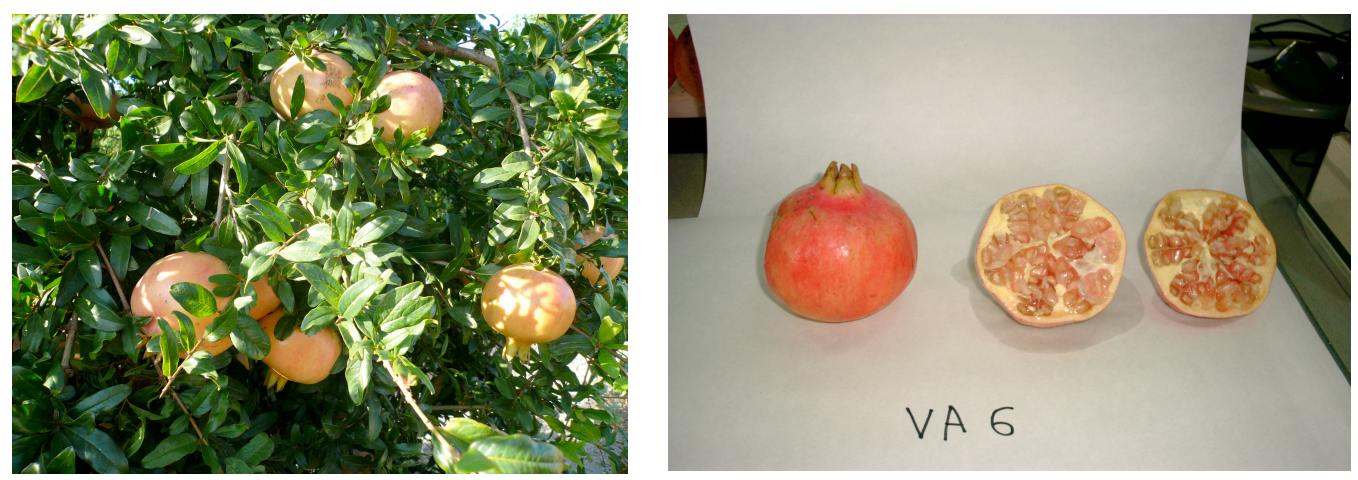

Figure 5.4. Pomegranate fruits (cv Valenciana)

The Mollar group, the most important and most widely cultivated, is marketed in Spain and in other European Union countries, and its fruits are harvested from end-September to mid-November (Figure 5.1). 
Valenciana fruits mature earlier (from early-August to mid-September) but are characterized for having lower quality and size than those of the Mollar group (Figures 5.3 and 5.4). Piñón tierno de Ojós is an interesting cultivar for its large fruits of a sour-sweet taste. However, Borde of Albatera, with its sour taste, has a woody portion of $\approx 13 \%$ (Hernández, et al., 1999). In addition to the Spanish cultivars there is increasing interest on the past of Spanish growers in foreign cultivars such as Wonderful, which, in spite of having a yield that is usually from medium to low, is one of the most widely cultivated cultivars in the world. It has an attractive intense red color and a sour or sour-sweet taste, depending on the harvest time (Melgarejo et al., 2010).

\subsection{Pruning and thinning}

In some places growers prefer the multiple trunk method as way of growing pomegranates. In contrast, and in order to facilitate certain cultivation practices (pruning, thinning, spaying, fruit harvesting, etc.), there is a growing trend to prefer only one trunk. The single trunk (30-50 $\mathrm{cm}$ ) is split into 3-4 main branches, and the tree is trained frequently to a vase shape to a height below $4 \mathrm{~m}$ in order to reduce the expense of manual treatments and increase the effectiveness of spraying. Nevertheless, some growers do not like this vase shape because the tree may be overexposed to sunlight increasing the incidence of fruit sunburn.

In general pomegranates are pruned in the winter and some care is also taken in the summer. In the winter the height of the trees is brought back to the desired height, while broken, bent and interfering branches are removed. In order to keep the interior of the tree open during growing season, summer pruning is carried out according to needs (Blumenfeld et al., 2000). New branches on trunks are removed by hand while suckers are sprayed by chemicals. 
An important problem in pomegranate production in the first years of production is the tendency of young branches to bend, which facilitates fruit contact with ground and disrupts the tree structure. This problem can be avoided by supporting the branches.

Thinning is an expensive cultural practice, which consists of reducing fruit load at an immature stage and thus allowing the remaining fruits to develop to the required market size. This practice is conducted in early June and can be repeated at the end of June, preventing fruit from touching, because the point of contact favours conditions for the development of pests. The correct distribution of fruits on the branches is considered to be $20-25 \mathrm{~cm}$ distance between fruits. Melgarejo et al. (2010) suggested that fruit thinning for attaining a desirable fruit size eliminates approximately $10 \%$ of the total pomegranate production.

\subsection{Pomegranate irrigation}

Pomegranate is considered to be a drought-resistant crop because it supports heat and can thrives well in arid and semiarid areas, even under desert conditions (Aseri et al., 2008). For this, and from a commercial point of view, pomegranate is a very interesting fruit plant species due to its adaptation to a wide range of climates and soil conditions, and commercial orchards of pomegranate trees are now grown in many regions of the world, including the Mediterranean Basin (Stover and Mercure, 2007; Holland et al., 2009).

In arid and semiarid conditions, to reach optimal growth, yield and fruit quality for commercial production the crop requires regular irrigation throughout the dry season (Prasad et al., 2003; Shaliendra and Narendra, 2005; Sulochanamma et al., 2005; Levin, 2006; Holland et al., 2009). However, few studies have been conducted into the effect of irrigation levels and irrigation management in adult pomegranate plants under field conditions. Intrigliolo et al. (2011 and 2013) suggested preliminary 
irrigation recommendations for pomegranate trees considering regulated deficit irrigation with water restrictions during flowering and fruit set as the most convenient strategy to cope with water scarcity or high water prices. Blumenfeld et al. (2000) suggested a total water amount of around 600 $\mathrm{mm}$ per season in Israel, in addition to the expected $450 \mathrm{~mm}$ of rainfall. Also, as a general guide for pomegranate irrigation, these authors proposed starting with $1.5 \mathrm{~mm}_{\text {day }}{ }^{-1}$ in the spring, rising to $5 \mathrm{~mm} \mathrm{day}^{-1}$ in the summer days close to harvesting and very little postharvest irrigation. Holland et al. (2009) indicated that the total amount of water for pomegranate irrigation for the entire season should be 500 to $600 \mathrm{~mm}$, depending on the type of soil and the weather conditions and that irrigation has to be applied daily during the irrigation period. Melgarejo et al. (2010) suggested that the seasonal irrigation requirements for pomegranate are $527 \mathrm{~mm}$.

Bhantana and Lazarovitch (2010) measured the evapotranspiration $(\mathrm{ET})$, crop coefficients $(\mathrm{Kc})$ and growth in two young pomegranate tree cultivars grown in lysimeters with irrigation water of varying electrical conductivity. Their results indicated that salinity had a significant effect on both daily ET and total ET and that the calculated value of $\mathrm{Kc}$ is applicable for irrigation scheduling in young pomegranate orchards using irrigation water with various salinities. Moreover, Ashraf and Majeed (2006) proposed pomegranate Kc values and water requirements for different agro-climatic zones in Balochistan.

Information on pomegranate fertigation is very scarce. Blumenfeld et al. (2000) indicated that no fertigation experiments had been made in Israel and that the amounts of fertilizers used were based on general knowledge for other plants, suggesting around 200-300 kg N ha-1 with about the same amount of $\mathrm{K}_{2} \mathrm{O}$. In Spain, growers apply around $150 \mathrm{~kg} \mathrm{~N}$ $\mathrm{ha}^{-1}, 70 \mathrm{~kg} \mathrm{P}_{2} \mathrm{O}_{5} \mathrm{ha}^{-1}$ and $150 \mathrm{~kg} \mathrm{~K}_{2} \mathrm{O} \mathrm{ha}{ }^{-1}$. 


\subsection{Pomegranate fruit composition}

Despite the fact that pomegranate has frequently been considered a minor crop and is deemed either a small tree or a large shrub, its fruits are large berries with an edible part that has been extensively used in medicine by many traditional cultures due to its health-promoting benefits in the treatment or reduction in the risk of chronic disorders such as cancer, atherosclerosis, diabetes, blood pressure and other diseases (Langley, 2000; Michel et al., 2005; Katz et al., 2007; Lansky and Newman, 2007; Holland et al., 2009). Pomegranate's anti-inflammatory action, due to the high content of tannins, is important in inflammatory processes during the creation of the atheroma plaque, and could therefore mediate or prevent pathological processes in the cardiovascular system such as heart attacks (Andreu-Sevilla et al., 2008). Pomegranate juice seems to prevent the oxidation of LDL (Low Density Lipoprotein) in bloodstream vessels; this fact is important in creating the atheroma and the subsequent action of related inflammatory effects. Also, pomegranate rind extract has antibacterial, anti-inflammatory and anti-allergic activities and could be considered a nutraceutical product (Panichayupakaranant et al., 2010).

According to Borochov-Neori et al. (2009), consumer satisfaction and producer profitability require that the pomegranate fruit excel in two aspects: health-related quality (antioxidative capacity) and fruit attractiveness (mainly colour and the taste of the arils and their juice). Although there is no correlation between the peel colour and aril colour, the colour of pomegranates affects market acceptance and, as is usual in stone fruits, consumers prefer pomegranate fruits with a red color peel (Opara et al., 2009). In this sense, recent studies showed that the external color of pomegranate is correlated with the number of days from the beginning of its development (Manera et al., 2013). During ripening the values of $L^{*}, b^{*}$ and $H^{\circ}$ values decrease while the values of $a^{*}$ and $C^{*}$ values increased (Manera et al., 2012). 
The increase in the $a^{*}$ values of the arils during ripening is directly related with the increased biosynthesis and accumulation of anthocyanin pigments, which are responsible for the intense pink-red color of ripe pomegranate fruits. The most abundant anthocyanin in sour cultivars are cyanidin 3,5-diglucoside, followed by cyanidin 3-glucoside and delphinidin 3,5-diglucoside, whereas in sweet cultivars the most abundant is cyanidin 3-glucoside, while delphinidin 3,5-diglucoside and pelargonidin 3glucoside are found in lower concentrations (Hernández et al., 1999; Kulkarni and Arandhya, 2005).

Arils and seeds are the edible part of pomegranate fruit, representing $55 \%$ of the whole fruit, and their composition changes as fruit ripens on the tree. This change is mainly characterized by an increase in the sugar content and a decrease in total acidity (TA) in arils (Kulkani and Aradhya, 2005). Hence, the ratio TSS/TA, referred to as maturity index (MI), is commonly used to define the taste of pomegranate fruit during development (Hernandez et al., 1999). MI values for pomegranate fruits range from 5 to 7 for sour cultivars, from 17 to 24 for sour-sweet cultivars and from 31 to 98 for sweet cultivars (Martínez et al., 2006). Fructose and glucose are the major sugars (Melgarejo et al., 2000; Ozgen et al., 2008). Sucrose is not present in all cultivars and its content may only reach trace level, especially in sour-sweet fruits (Melgarejo et al., 2000). Citric, malic and oxalic acids are considered as the major organic acids in pomegranates, while tartaric, succinic and quinic acids are found in minor quantities. The acid composition in the arils changes as a function of the cultivar and they are a key part of the sour-sweet balance of pomegranate fruits (Legua et al., 2000). The bioelement levels in pomegranate arils follow the order $\mathrm{K}>\mathrm{Ca}>\mathrm{Mg}>\mathrm{Na}>\mathrm{Fe}>\mathrm{Zn}>\mathrm{Cu}>$ $\mathrm{Mn}$, making $\mathrm{K}$ and $\mathrm{Fe}$ the predominant macro and microelements, respectively (Mirdehghan and Rahemi, 2007; Fawole and Opara, 2013).

Although the exact values of the antioxidant capacity depends on many factors, including cultivar, fruit maturity index, environmental conditions, plant water status, etc. pomegranates have a very high content 
of phenolic compound, which are the bioactive compounds with the highest antioxidant activity. For this, the number of studies on the beneficial properties of pomegranate is steadily increasing. The main compounds responsible for the antioxidant capacity of pomegranate fruit are punicalagins, anthocyanins and ellagic acid. However, punicalagins played a more important role in the antioxidant capacity than anthocyanins (Gil et al., 2000; Tzulker et al., 2007). This antioxidant activity decreases to minimum values during fruit development and increases after that to reach the highest levels when fruit is commercially mature (Kulkarni and Aradhya, 2005). Seeram et al. (2008) concluded that the antioxidant capacity in beverages rich in polyphenols followed the order: pomegranate juice $>$ red wine $>$ grape juice $>$ blueberry juice $>$ blackberry juice $=$ cranberry juice $>$ orange juice $=$ iced tea beverages $=$ apple juice .

\subsection{Fruit physiological disorders}

One of the foremost physiological disorders, and which has a severe economic impact on pomegranate fruit value, is the cracking of ripe fruit (Blumenfeld et al., 2000; Holland et al., 2009). Such defects seem to be directly related to fruit water status, because regular irrigation can decrease the damage (Prasad et al., 2003) and cracking is a problem in areas where fruit maturation overlaps the rainy season (Figure 5.5). Moreover, the conviction exists among growers that rain falling on mature pomegranate fruits following the end of the dry season can induce rapid fruit cracking (Holland et al., 2009), although no scientific evidence has been proposed for the mechanisms developed. Nevertheless, regardless of environmental conditions, some aspects of pomegranate fruit splitting could be genetically controlled (Hepaksoy et al., 2000) and, pomegranate fruit cracking can be considered as the last stage of normal fruit developmental process for spreading its seeds. 

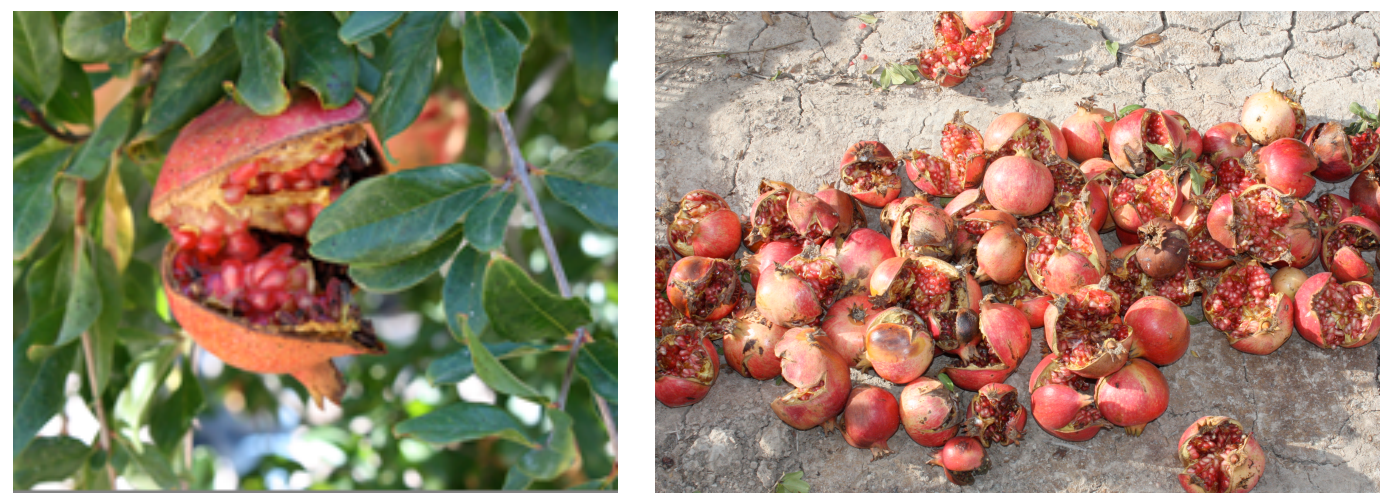

Figure 5.5. Pomegranate peel cracking

Another physiopathy is sunburn of fruit rind, which reduces its value and happens only at a certain physiological stage of fruit development (Figure 5.6). The cause of this physiological disorder is the combined action of high solar radiation, low humidity and high temperatures (Holland et al., 2009). For this reason, cultivars which have a willowy canopy are not affected by this disorder and, early cultivars which are less exposed to solar radiation are less susceptible than late cultivars to sunburn. Shading can reduce sunburn incidence while the application of kaolin not only reduces sunburn incidence (Melgarejo et al., 2004) but also increases pomegranate fruit colour (Yazici and Kaynak, 2006).

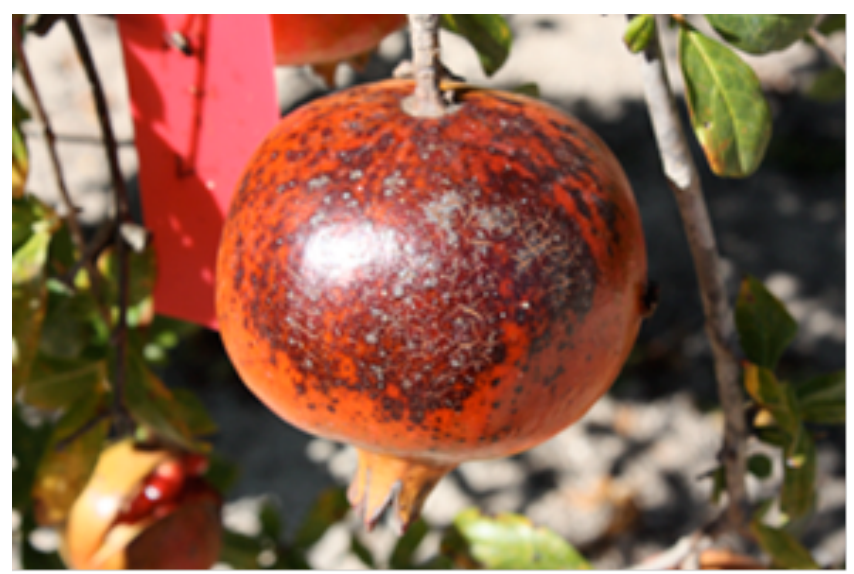

Figure 5.6. Sunburn on pomegranate fruit rind 


\section{References}

Andreu-Sevilla, A. J., Signes-Pastor, A. J., Carbonell-Barrachina, A. A. 200). La granada y su zumo. Producción, composición y propiedades beneficiosas para la salud. Alim. Equi. Tecnol. 234: 36-39.

Aseri, G.K., Jain, N., Panwar, J., Rao, A.V., Meghwal, P.R. 2008. Biofertilizers improve plant growth, fruit yield, nutrition, metabolism and rhizosphere enzyme activi-ties of pomegranate (Punica granatum L.) in Indian Thar desert. Sci. Hortic.-Amsterdam 117: 130-135.

Ashraf, M., Majeed, A. 2006. Water requirements of major crops for different agro-climatic zones of Balochistan. The World Conservation Union (IUCN) Pakistan, Water Programme. Balochistan Programme Office. vii+139 pp.

Bhantana, P., Lazarovitch, N. 2010. Evapotranspiration crop coefficient and growth of two young pomegranate (Punica granatum L.) varieties under salt stress. Agric. Water Manage. 97: 715-722.

Blumenfeld, A., Shaya, F., Hillel, R. 2000. Cultivation of Pomegranate. CIHEAM: Options Méditerranéennes. http://ressources.ciheam.org/om/pdf/a42/00600264.pdf

Borochov-Neori, H., Judeinstein, S., Tripler, E., Harari, M., Greenberg, A., Shomer, I., Holland, D. 2009. Seasonal and cultivar variations in antioxidant and sensory quality of pomegranate (Punica granatum L.) fruit. J. Food Compos. Anal. 22: 189-195.

Carbonell-Barrachina, A.A., Calín-Sánchez, A., Bagatar, B., Hernandez, F., Legua, P., Martínez-Font, R., Melgarejo, P. 2012. Potential of Spanish sour-sweet pomegranates (cultivar C25) for juice industry. Food Sci. Technol. Int. 18: 129-138.

Fahan, A. 1976. The leaf, the flower, the seed. In: Plant Anatomy. Hakkibutz Hameuhad Publi., Jerusalem, p. 171-172, 321-394, 419430. 
Fawole, O. A., Opara, U. L. 2013. Changes in physical properties, chemical and elemental composition and antioxidant capacity of pomegranate (cv. Ruby) fruit at five maturity stages. Sci. HorticAmsterdam 150: 37-46.

Font Quer, P. 1959. Plantas medicinales. El Dioscórides renovado. Labor. Barcelona $\left(5^{\text {th }}\right.$ ed). $1033 \mathrm{pp}$.

Gil, M.I., Tomas-Barberán, F.A., Hess-Pierce, B., Holcroft, D.M., Kader, A.A. 2000. Antioxidant activity of pomegranate juice and its relationship with phenolic composition and processing. J. Agric. Food Chem. 48: 4581-4589.

Goor, A., Liberman, J. 1956. The pomegranate. J. Astmon (ed.). State of Israel, Ministry of Agriculture, Agr. Publ. Section, Tel-Aviv. p. 5-57.

Guarino, L., Miller, T., Baazara, M., Obadi, N. 1990. Socotra: The island of Bliss revisited. Diversity 6: 28-31.

Hepaksoy, S., Aksoy, U., Can, H.Z., Ui, M.A. 2000. Determination of relationship between fruit cracking and some physiological responses, leaf characteristics nand nutritional sataus of some pomegranate varieties. Options Méditerranéennes 42: 87-92.

Hernández, F., Melgarejo, P., Tomás-Barberán, F. A., Artés, F. 1999. Evolution of juice anthocyanins during ripening of new selected pomegranate (Punica granatum) clones. Eur. Food Res. Technol. 210: 39-42.

Holland, D., Hatib, K., Bar-Yàakov, I. 2009. Pomegranate: botany, horticulture, breed-ing. Hortic. Rev. 35: 127-191.

Intrigliolo, D.S., Bonet, L., Nortes, P.A., Puerto, H., Nicolás, E., Bartual, J. 2013. Pomegranate trees performance under sustained and regulated deficit irrigation. Irrig. Sci. 31: 959-970.

Intrigliolo, D.S., Nicolás, E., Bonet, L., Ferrer, P., Alarcón, J.J., Bartual, J. 2011. Water relations of field grown Pomegranate trees (Punica 
granatum) under different drip irrigation regimes. Agric. Water Manage. 98: 691-696.

Janick, J. 2007. Fruits of the Bibles. HortScience 42: 1072-1076.

Katz, S.R., Newman, R.A., Lansky, E.P. 2007. Punica granatum: heuristic treatment for diabetes mellitus. J. Med. Food 10: 213-217.

Kulkarni, A.P., Aradhya, S.M. 2005. Chemical changes and antioxidant activity in pomegranate arils during fruit development. Food Chem. 93: 319-324.

Langley, P. 2000. Why a pomegranate? BMJ 321: 1153-1154.

Lansky, E.P., Newman, R.A. 2007. Punica granatum (pomegranate) and its potential for prevention and treatment of inflammation and cancer. J. Ethnopharmacol. 109: 177-206.

Legua, P., Melgarejo, P., Martinez, M., Hernandez, F. 2000. Evolution of sugars and organic acid content in three pomegranate cultivars (Punica granatum L.). Options Méditerranéennes 42: 99-104.

Levin, 2006. Pomegranate: A botanical perspective. In: N.P. Seeram, R.N. Schulman, D. Heber (eds.), Pomegranates: ancient roots to modern medicine. CRC Press Taylor and Francis Group, Boca Ratón, FI. p. 199-210.

Levin, G.M. 2006. Pomegranate roads: a Soviet botanist's exile from Eden. B.L. Baer (ed.). Floreat Press, Forestville, CA. p. 15-183.

Manera, F.J., Legua, P., Melgarejo, P., Brotons, J.M., Hernández, F., Martínez, J.J. 2013. Determination of a colour index for fruit of pomegranate varietal group "Mollar de Elche". Sci. Hortic.-Amsterdam $150,360-364$.

Manera, F.J., Martínez, J.J., Martínez, R., Conesa, A., Hernández, F., Legua, P., Melgarejo, P., Porras, I. 2012. The evolution of pomegranate fruits colour. Opt. Pura Apl. 43: 153-159. 
Martínez, J.J., Hernández, F., Abdelmajid, H., Legua, P., Martínez, R., El Amine, A., Melgarejo, P. 2012. Physico-chemical characterization of six pomegranate cultivars from Morocco: Processing and fresh market aptitudes. Sci. Hortic.-Amsterdam 140: 100-106.

Martínez, J.J., Melgarejo, P., Hernández, F., Salazar, D.M., Martínez, R. 2006. Seed characterisation of five new pomegranate (Punica granatum L.) varieties. Sci. Hortic.-Amsterdam 110: 241-246.

Melgarejo, P., Hernández, F., Legua, P. 2010. El Granado, su problemática y usos. I Jornadas Nacionales sobre el Granado. Elche p. 7-27.

Melgarejo, P., Martínez, J.J., Hernández, F., Martínez, F.R., Barrows, P., Erez, A. 2004. Kaolin treatment to reduce pomegranate sunburn. Sci. Hortic.-Amsterdam 100: 349-353.

Melgarejo, P., Martínez-Valero, R., Guillamón, J.M., Miró, M., Amorós, A. 1997. Phenological stages of the pomegranate tree (Punica granatum L.). Ann. Appl. Biol. 130: 135-140.

Melgarejo, P., Salazar, D.M., Artés, F. 2000. Organic acids and sugars composition of harvested pomegranate fruits. Eur. Food Res. Technol. 211: 185-190.

Mena, P., García-Viguera, C., Navarro-Rico, J., Moreno, D. A., Bartual, J., Saura, D., Martí, N. 2011. Phytochemical characterisation for industrial use of pomegranate (Punica granatum L.) cultivars grown in Spain. J. Sci. Food Agr. 91: 1893-1906.

Michel, D.S., Melanie, E.R.N., Gerdi, W., Jennifer, J.D., Mailine, H.C., Ruth, M., Caren, J., Raisin, R.N., Dean, O. 2005. Effect of pomegranate juice consumption on mycocardial perfusion in patient with coronary heart disease. Am. J. Cardiol. 96: 810-814. 
Mirdehghan, S. H., Rahemi, M. 2007. Seasonal changes of mineral nutrients and phenolics in pomegranate (Punica granatum L.) fruit. Sci. Hortic.-Amsterdam 111: 120-127.

Morton, J. 1987. Fruits of warm climates. Miami, FL

Morton, J. 1987. Pomegranate. Fruits of Warm Climates. Julia F. Morton. Miami, FL, 352-355 pp.

Opara, L.U., Al-Ani, M.R., Al-Shuaib, Y.S. 2009. Physico-chemical properties, vitamin C content, and antimicrobial properties of pomegranate fruit (Punica granatum L.). Food Bioprocess Tech. 2: 315-321.

Ozgen, M., Durgac, C., Serce, S., Kaya, C. 2008. Chemical and antioxidant properties of pomegranate cultivars grown in the Mediterranean region of Turkey. Food Chem. 111: 703-706.

Panichayupakaranant, P., Tewtrakul, S. Yuenyongsawad, S. 2010. Antibacterial, anti-inflammatory and anti-allergic activities of standardized pomegranate rind extract. Food Chem. 123: 400-403.

Prasad, R.N., Bankar, G.J., Vashishtha, B.B. 2003. Effect of drip irrigation on growth, yield and quality of pomegranate in arid region. Indian $\mathrm{J}$. Hort. 60: 140-142.

Seeram, N.P., Aviram, M., Zhang, Y., Henning, S.M., Feng, L., Dreher, M., Heber, D. 2008. Comparison of antioxidant potency of commonly consumed polyphenol rich beverages in the United States. J. Agric. Food Chem. 56: 1415-1422.

Shaliendra, A., Narendra, A. 2005. The effect of trickle irrigation on growth, yield and quality of pomegranate (Punica granatum) cv. Ganesh in Chhattisgarh region. Mysore J. Agric. Sci. 39: 175-181.

Sharma, K.K., Dhilom, W.S. 2002. Evaluation of evergreen varieties of pomegranate under Punjab conditions. Agr. Sci. Digest 22: 42-44. 
Shilikina, I.A. 1973. On the xylem anatomy of the genus Punica L. Bot. Z. 58: $1628-1630$.

Singh, D.B., Samadia, D.K., Kingsly, A.R.P. 2006. Conservation, characterization and evaluation of pomegranate germplasm under arid ecosystem of India. In: ISHS Int. Symp. Pomegranate and Minor Mediterranean Fruits. Abstract contributed papers. Adana. Turkey. p. 15.

Still, D.W. 2006. Pomegranates: A botanical perspective, In: N.P. Seeram, R.N. Schulman, and D. Heber (eds.). Pomegranates: Ancient roots to modern medicine. CRC Press, Boca Raton, FL. p. 199-209.

Stover, E., Mercure, E.W., 2007. The Pomegranate: a new look at the fruit of paradise. HortScience 42: 1088-1092.

Sulochanamma, B.N., Yellamanda, Reddy, T., Subbi Reddy, G., 2005. Effect of basin and drip irrigation on growth, yield and water use efficiency in pomegranate cv Gennesh. Acta Hortic. 696: 277-279.

Tzulker, R., Glazer, I., Bar-llan, I., Holland, D., Aviram, M., Amir, R. 2007. Antioxidant activity, polyphenol content and related compounds in different fruit juices and homogenates prepared from 29 different pomegranate accessions. J. Agric. Food Chem. 55: 9559-9570.

Yazici, K., Kaynak, L. 2006. Effect of kaolin and ahadding treatments on sunburn on fruit of Hicaznar cuktivar of pomegranate (Punica granatum L. CV. Hicaznar). In: $1^{\text {st }}$ Int. Symp. Pomegranate and Minor Mediterranean Fruits. Abstracts contributed papers. Adana, Turkey. p. 39.

Zukovskij, P.M. 1950. Punica. In: Cultivated plants and their wild relatives. State Publ. House Sovietic Science, Moscow. p. 60-61. 
6. Publications 
Environmental and Experimental Botany 77 (2012) 19-24

Contents lists available at SciVerse ScienceDirect

Environmental and Experimental Botany

journal homepage: www.elsevier.com/locate/envexpbot

Plant water relations of leaves of pomegranate trees under different irrigation conditions

P. Rodríguez ${ }^{a}$, C.D. Mellisho ${ }^{b}$, W. Conejero ${ }^{b}$, Z.N. Cruz $^{a}$, M.F. Ortuño ${ }^{b}$, A. Galindo ${ }^{b}$, A. Torrecillas $^{\text {b,c, }, *}$

apto. Fisiología y Bioquirnica, instituto Nacional de Ciencias Agricotas (INCA), Crra. de Tapaste, km 3.5, San josé de Las Lajas (La Habana), Cuba

b Dpto. Riego, Centro de Edafologiay Biología Aplicada del Segura (CSIC), P.O. Box 164. E-30100 Espinardo (Murcia), Spain
cUnidad Asociada al CSIC de Horticultura Sostenible en Zonas Aridas (UPCT-CERAS), Paseo Alfonso XIII S/n, E-30203 Cartagena (Murcia), Spain

\section{Methodology}

See page 53.

\section{Results}

The results indicated that pomegranate plants confront water stress by developing stress avoidance and stress tolerance mechanisms. From the time of deficit irrigation (T1) and water withholding (T2) began to be applied, leaf conductance decreased in order to control water loss via transpiration and to avoid leaf turgor loss (stress avoidance mechanism). Close to the end of the stress period, when maximum stress levels had developed, active osmotic adjustment was triggered, contributing to the maintenance of leaf turgor (stress tolerance mechanism). Other drought tolerance characteristics commonly seen in xeromorphic plants were also observed, such as high relative apoplastic water content $(42-58 \%)$, which would contribute to the retention of water at low leaf water potentials.

\section{Conclusions}

Pomegranate plants confront water stress by developing stress avoidance and stress tolerance mechanisms. These mechanisms were seen to be complementary and take place gradually. From the beginning of deficit irrigation (T1) and water withholding (T2) leaf conductance decreased in order to control water loss via transpiration and avoid leaf turgor loss (stress avoidance mechanism). When, close to the end of the stress period, maximum stress levels were developed, active osmotic adjustment was triggered, which could have contributed to the maintenance of leaf turgor (stress tolerance mechanism). Furthermore, other drought tolerance characteristics were observed in pomegranate including high relative apoplastic water content. 


\title{
Plant water relations of leaves of pomegranate trees under different irrigation conditions
}

\author{
P. Rodríguez ${ }^{a}$, C.D. Mellisho ${ }^{b}$, W. Conejero ${ }^{b}$, Z.N. Cruz ${ }^{a}$, M.F. Ortuño ${ }^{b}$, A. Galindo ${ }^{b}$, A. Torrecillas ${ }^{b}, c, *$ \\ a Dpto. Fisiología y Bioquímica, Instituto Nacional de Ciencias Agrícolas (INCA). Ctra. de Tapaste, km 3.5, San José de Las Lajas (La Habana), Cuba \\ ${ }^{b}$ Dpto. Riego, Centro de Edafología y Biología Aplicada del Segura (CSIC), P.O. Box 164, E-30100 Espinardo (Murcia), Spain \\ ' Unidad Asociada al CSIC de Horticultura Sostenible en Zonas Áridas (UPCT-CEBAS), Paseo Alfonso XIII s/n, E-30203 Cartagena (Murcia), Spain
}

A R T I C L E I N F O

\section{Article history:}

Received 2 November 2010

Received in revised form 24 August 2011

Accepted 27 August 2011

\section{Keywords:}

Elastic adjustment

Gas exchange

Osmotic adjustment

Punica granatum

Water relations

Water stress

\begin{abstract}
A B S T R A C T
Adult pomegranate trees (Punica granatum (L.) cv. Mollar de Elche) were submitted to three irrigation treatments. Control (T0) plants were drip irrigated in order to guarantee non-limiting soil water conditions, T1 plants (deficit irrigation) were drip irrigated according to the criteria commonly used by the growers in the area and T2 plants were subjected to water withholding and recovery periods of 34 and 6 days, respectively, during the summer of 2009. The results indicated that pomegranate plants confront water stress by developing stress avoidance and stress tolerance mechanisms. From the time of deficit irrigation (T1) and water withholding (T2) began to be applied, leaf conductance decreased in order to control water loss via transpiration and to avoid leaf turgor loss (stress avoidance mechanism). Close to the end of the stress period, when maximum stress levels had developed, active osmotic adjustment was triggered, contributing to the maintenance of leaf turgor (stress tolerance mechanism). Other drought tolerance characteristics commonly seen in xeromorphic plants were also observed, such as high relative apoplastic water content (42-58\%), which would contribute to the retention of water at low leaf water potentials.
\end{abstract}

(c) 2011 Elsevier B.V. All rights reserved.

\section{Introduction}

Spanish Mediterranean agrosystems are characterized by the aridity of the climate and the persistent shortage and low quality of the available water resources. Moreover, recent years have seen growing competition for the water that is available due to the expansion of industrial activity, the spread of new urban, tourist and recreational areas and the indispensable environment preservation measures. Collins et al. (2009) indicated that during the last thirty years drought periods have hit $17 \%$ of European territory, affecting $11 \%$ of the population, and have caused losses of $€ 100$ billion.

Consequently, the fact that Mediterranean agrosystems must face up to the need to cope with water scarcity cannot be questioned because any policy of continuous expansion of the supply is unsustainable (Pereira et al., 2002). In this sense, fruit culture in arid and semiarid areas must be directed towards the use of less water-demanding and more stress-resistant plant materials which, together with deficit irrigation, will allow significant water savings and the profitable production of high quality fruits.

* Corresponding author. Current address: P.O. Box 164, E-30100 Espinardo (Murcia), Spain. Tel.: +34968 396330; fax: +34968 396213 .

E-mail address: atorreci@cebas.csic.es (A. Torrecillas).
Pomegranate (Punica granatum L.), which is believed to be native to the southern Caspian belt (Iran) and Northeast Turkey (Janick, 2007), belongs to the family Punicaceae and is a very interesting fruit plant species from a commercial point of view due to its adaptation to a wide range of climates and soil conditions. Commercial orchards of pomegranate trees are now grown in many regions of the world, including the Mediterranean Basin countries (Stover and Mercure, 2007; Holland et al., 2009). However, pomegranate has frequently been considered a minor crop, although the growing interest in the consumption of its fruits due to their organoleptic characteristics and their perceived health benefits is beginning to change the way it is regarded. Indeed pomegranate has a high content of vitamins, minerals and antioxidants, and shows phytochemical and pharmacological activity in the treatment and prevention of cancer, atherosclerosis and other diseases (Michel et al., 2005; Ephraim and Robert, 2007).

Woody crops that can confront drought develop morphological and/or physiological mechanisms that enable them to avoid or postpone desiccation, or simply because they can tolerate desiccation (Savê et al., 1995; Torrecillas et al., 1996). The problem of assessing to what extent gas exchange and growth can resume and productivity may be maintained once water stress is relieved, is particularly relevant for perennial crops cultivated in arid and semiarid regions. Pomegranate is considered to be a drought-resistant crop because it supports heat and can thrives well in arid and 
semiarid areas, even under desert conditions (Aseri et al., 2008). However, in arid and semiarid conditions, to reach optimal growth, yield and fruit quality for commercial production the crop requires regular irrigation throughout the dry season (Prasad et al., 2003; Shaliendra and Narendra, 2005; Sulochanamma et al., 2005; Levin, 2006; Holland et al., 2009).

Despite the growing importance of pomegranate and the ever more frequent water shortages experienced in the most suitable regions for its growth, to the best of our knowledge, no information exists on the mechanisms developed by pomegranate trees to confront drought. For these reasons, the present study was undertaken to investigate plant water relations in adult pomegranate trees under field conditions, in order to establish the stress avoidance and stress tolerance mechanisms developed in response to water stress and recovery. The extent of elastic and osmotic adjustments, turgor maintenance, leaf conductance, leaf water potential at the turgor loss point, relative water content at the turgor loss point and relative apoplastic water content were measured.

\section{Materials and methods}

\subsection{Experimental conditions, plant material and treatments}

The experiment was carried out during the summer of 2009 at a farm located $22 \mathrm{~km} \mathrm{SE}$ of the city of Murcia (Spain) $\left(37^{\circ} 57^{\prime} \mathrm{N}\right.$, $\left.0^{\circ} 56^{\prime} \mathrm{W}\right)$. The soil is a Xeric torriorthent with silt loam texture. Analytical data showed a high lime content (46\% calcium carbonate), very low organic matter content $(0.92 \%)$, low cationic exchange capacity ( 7.93 mequiv. $100 \mathrm{~g}^{-1}$ ), and low available potassium and phosphorus levels. The irrigation water had an electrical conductivity of between 1.7 and $2.2 \mathrm{dS} / \mathrm{m}$ and a $\mathrm{Cl}^{-}$concentration ranging from 36 to $48 \mathrm{mgl}^{-1}$. The climate of the area is typically Mediterranean, with mild winters, low annual rainfall, and hot dry summers. During the experimental period, average daily maximum and minimum air temperatures were 33 and $21^{\circ} \mathrm{C}$, respectively, mean daily air vapour pressure deficit $\left(V^{2} D_{m}\right)$ (Allen et al., 1998) ranged from 1.12 to $3.11 \mathrm{kPa}$, and reference crop evapotranspiration (ETo, Allen et al., 1998) was $223 \mathrm{~mm}$. No rainfall was recorded during the experimental period.

The plant material consisted of 10-year old pomegranate trees (P. granatum (L.) cv. Mollar de Elche). Tree spacing followed a $3 \mathrm{~m} \times 5 \mathrm{~m}$ pattern. Pest control and fertilization practices were those usually used by the growers, and no weeds were allowed to develop within the orchard.

Three irrigation treatments were considered, in which irrigation was carried out daily and during the night using a drip irrigation system with one lateral pipe per tree row. The irrigation in treatment T1 was performed according to the criteria commonly used by the growers in the area, using two emitters (each delivering $41 \mathrm{~h}^{-1}$ ) per plant. In order to guarantee non-limiting soil water conditions, control plants (treatment T0) were irrigated using six emitters (each delivering $41 \mathrm{~h}^{-1}$ ) per plant. In treatment T2 irrigation was withheld for 34 days (from day of the year (DOY) 209 to 243 ). The recovery of $T 2$ plants was ensured by re-irrigation at the levels used in T0 for 6 days (DOY 244-250).

\subsection{Measurements}

Leaf water potential $\left(\Psi_{1}\right)$ was determined on the south facing side and the middle third of the trees, in two fully developed leaves per tree of each replicate, using a pressure chamber (model 3005 , Soil Moisture Equipment Co., Santa Barbara, CA, USA), as recommended by Turner (1988). Midday ( $12 \mathrm{~h}$ solar time) stem water potential ( $\left.\psi_{\text {stem }}\right)$ was measured in a similar number and type of leaves as used for $\Psi_{1}$, enclosing leaves in a small black plastic bag covered with aluminium foil for at least $2 \mathrm{~h}$ before measurements in the pressure chamber (Fulton et al., 2001; Shackel, 2011).

Leaf conductance $\left(g_{1}\right)$ in attached leaves was measured with a steady-state porometer (LI-1600, LICOR Inc., Lincon, USA) on the abaxial surface of the leaves and in a similar number and type of leaves as used for the $\psi_{1}$ measurements.

After measuring predawn $\left(\psi_{\mathrm{pd}}\right)$ and midday $\left(\psi_{\mathrm{md}}\right)$ leaf water potentials, the leaves were frozen in liquid nitrogen and the osmotic potential was measured after thawing the samples and expressing sap, using a vapour pressure osmometer (Wescor 5500, Logan, USA). Predawn ( $\left.\Psi_{\text {ppd }}\right)$ and midday ( $\left.\Psi_{\text {pmd }}\right)$ leaf turgor potentials were derived as the difference between osmotic and water potentials. To estimate predawn leaf osmotic potential at full turgor $\left(\Psi_{\mathrm{os}}\right)$, excised leaves were sealed in plastic bags immediately after excision and subjected to a rehydration treatment by dipping their petioles in distilled water for $24 \mathrm{~h}$ at $4^{\circ} \mathrm{C}$. Rehydrated leaves were frozen in liquid nitrogen before measuring the osmotic potential in an osmometer as indicated above (Sánchez-Blanco et al., 2002; Torrecillas et al., 2003; Gimeno et al., 2009).

Estimates of $\Psi_{\mathrm{os}}$, leaf water potential at the turgor loss point $\left(\Psi_{\text {tlp }}\right)$, leaf bulk modulus of elasticity $(\epsilon)$, relative water content at the turgor loss point $\left(\mathrm{RWC}_{\mathrm{tlp}}\right)$ and relative apoplastic water content $\left(\mathrm{RWC}_{\mathrm{a}}\right.$ ) were obtained from pressure-volume (PV) analyses of leaves (Tyree and Hammel, 1972; Tyree and Richter, 1981, 1982; Savê et al., 1993). At the end of the stress period, leaves were excised at predawn and resaturated as indicated for $\psi_{\mathrm{os}}$. The resaturated leaves were weighed using an analytical balance $( \pm 0.1 \mathrm{mg}$ precision), placed into the pressure chamber (lined with damp filter paper) and slowly pressurized $\left(0.025 \mathrm{MPa} \mathrm{s}^{-1}\right)$ until the balance pressure was reached (when the leaf sap appeared through the cut petiole protruding from the chamber). Once depressurized, the leaf was allowed to transpire outside the pressure chamber on the laboratory bench at room temperature $\left(22 \pm 2^{\circ} \mathrm{C}\right)$. Leaves were repeatedly weighed and their balance pressures determined over the full range of the pressure gauge (Kikuta and Richter, 1986). Data for initial saturated weight, intermediate fresh weight (corresponding to values for $\Psi_{1}$ ), and final dry weight (at $80^{\circ} \mathrm{C}$ for $48 \mathrm{~h}$ ) were used to calculate the relative water content (RWC) (Barrs and Weatherley, 1962).

The curves were drawn using a type II transformation (Tyree and Richter, 1982). The reciprocal of water potential $\left(\psi_{1}\right)$ was plotted against RWC, the resultant relationships displaying both linear and non-linear regions. Extrapolation on the straight portion of the curve obtained for a value of $\mathrm{RWC}=1$ gave the reciprocal of the $\Psi_{\mathrm{os}}$ and extrapolation to the abscissa gave $\mathrm{RWC}_{\mathrm{a}}$. $\Psi_{\text {tlp }}$ and $\mathrm{RWC}_{\mathrm{tlp}}$ were estimated as the intersection between the linear and curvilinear portions of the PV curve. The leaf bulk modulus of elasticity $(\epsilon)$ of leaf tissue at $100 \%$ RWC $\left(\mathrm{RWC}_{\mathrm{o}}\right.$ ) was estimated according to Patakas and Noitsakis (1999) as $\epsilon$ $(\mathrm{MPa})=\left(\Psi_{\text {os }}-\Psi_{\text {stlp }}\right)\left(100-\mathrm{RWC}_{\mathrm{a}}\right) /\left(100-\mathrm{RWC}_{\text {tlp }}\right)$, where $\Psi_{\text {stlp }}$ is the osmotic potential at the turgor loss point and $\Psi_{\text {os }}$ values correspond to those obtained from the analysis of the PV curves.

\subsection{Statistical design and analysis}

The design of the experiment was completely randomized with four replications, each replication consisting of three adjacent tree rows, each with eleven trees. Measurements were taken on the inner tree of the central row of each replicate, which were very similar in appearance (leaf area, trunk cross sectional area, height, ground shaded area, etc.), while the other trees served as border trees. Data were analyzed using software (SPSS, 2002). Analysis of variance was performed and means values were compared by Duncan's multiple range test. All means were compared at the 0.05 level of significance. Values for each replicate were averaged before the mean and the standard error of each treatment were calculated. 

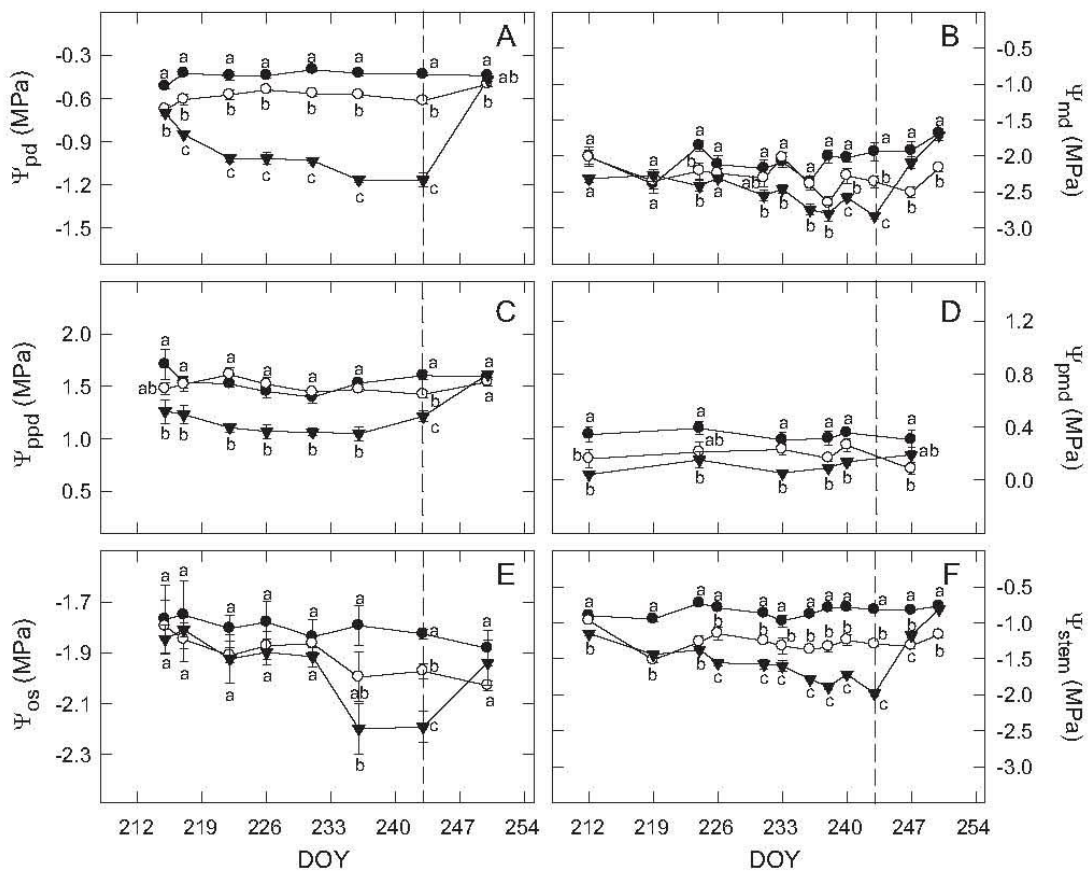

Fig. 1. Predawn $\left(\Psi_{\mathrm{pd}}, \mathrm{A}\right)$ and midday $\left(\Psi_{\mathrm{md}}, \mathrm{B}\right)$ leaf water potential, predawn $\left(\Psi_{\mathrm{ppd}}, \mathrm{C}\right)$ and midday $\left(\Psi_{\mathrm{pmd}}, \mathrm{D}\right)$ leaf turgor potential, predawn leaf osmotic potential at full turgor $\left(\Psi_{\mathrm{os}}, \mathrm{E}\right)$ and midday stem water potential $\left(\Psi_{\text {stern }}, \mathrm{F}\right)$ values (mean $\pm \mathrm{SE}$, not shown when smaller than symbols, $n=4$ ) for pomegranate plants in T0 (closed circles), T1 (open circles) and T2 (closed triangles) treatments during the experimental period. Different letters on data points at each date indicate significant differences according to Duncan's multiple range test $(P \leq 0.05)$. Vertical dashed line indicates the end of the water stress period.

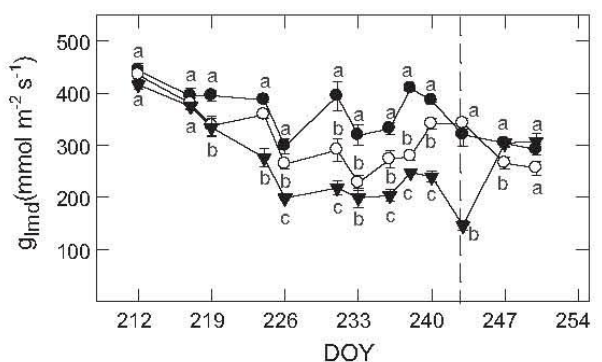

Fig. 2. Midday leaf conductance (gimd) values (mean \pm SE, not shown when smaller than symbols, $n=4$ ) for pomegranate plants in $\mathrm{T} 0$, T1 and $\mathrm{T} 2$ treatments during the experimental period. Symbols as in Fig. 1

\section{Results}

The $\Psi_{\mathrm{pd}}$ values showed significant differences between treatments during the stress period, the $\Psi_{\mathrm{pd}}$ values in $\mathrm{T} 0$ and $\mathrm{T} 2$ plants being significantly higher and lower, respectively, than those in the T1 treatment (Fig. 1A). The $\Psi_{\mathrm{pd}}$ values of T0 and T1 plants were constant during the experimental period, whereas $\Psi_{\mathrm{pd}} \mathrm{val}-$ ues in T2 plants showed a slightly tendency to decrease during the stress period, reaching minimum values at the end of this period and showing similar values to those in T0 plants when irrigation was resumed (Fig. 1A).

$\Psi_{\text {md }}$ values in T0 plants were fairly constant throughout the experimental period (Fig. 1B), while in T1 and T2 plants they were significantly lower than in T0 plants from DOY 238 and 231, respectively, to the last day of the drought period (DOY 243). When irrigation in T2 plants was resumed, $\Psi_{\mathrm{md}}$ values recovered rapidly, reaching similar values to those observed in T0 plants (Fig. 1B).

The $\Psi_{\text {os }}$ values of T0 plants were almost constant during the experimental period (Fig. 1E). No differences between treatments were observed from the beginning of the experimental period to DOY 236, when $\Psi_{\text {os }}$ values in T2 plants decreased to reach lower values than T0 plants (Fig. 1E). These values remained low in T2 until the end of the stress period, and then recovered with rewatering. The difference in $\Psi_{\text {os }}$ values between T0 and T1 plants was only significant at the end of the stress period, when they showed intermediate values between $\mathrm{T} 0$ and $\mathrm{T} 2$ values.

T0 plants showed constant $\Psi_{\text {stem }}$ values during the experimental period (Fig. 1F). Also, the $\Psi_{\text {stem values in all the three treatments }}$ were higher than the corresponding $\Psi_{\text {md }}$ values throughout the experimental period (Fig. 1B). The $\Psi_{\text {stem }}$ values of T1 plants were seen to have decreased by DOY 219 , remaining almost near constant and lower than the corresponding values in T0 plants from DOY 224 onwards. In contrast, $\Psi_{\text {stem }}$ values for T2 plants gradually decreased, reaching minimum values at the end of the stress period and recovering when irrigation was resumed (Fig. 1F).

$\Psi_{\text {ppd }}$ and $\Psi_{\text {pmd }}$ values in the three treatments were always above zero, indicating the maintenance of turgor during the experimental period (Fig. 1C and D). No differences between T0 and T1 were found in $\Psi_{\mathrm{ppd}}$ values, except at the end of stress period. Conversely, $\Psi_{\mathrm{ppd}}$ values in T2 plants were lower than in the other treatments from the beginning of the experiment and rapidly recovered after rewatering. The differences between treatments as regards $\Psi_{\text {pmd }}$ values were significant at almost all measurement times, with T0 plants showing the highest $\Psi_{\text {pmd }}$ values and T2 plants the lowest (Fig. 1D).

A gradual decrease in midday leaf conductance $\left(g_{\text {Imd }}\right)$ as a result of water stress was noted in T2 plants, which reached minimum 
Table 1

Effect of water stress on leaf osmotic potential at turgor loss point $\left(\Psi_{\text {tp }}\right)$, relative water content at turgor loss point $\left(\mathrm{RWC}_{\mathrm{tlp}}\right)$, relative apoplastic water content $\left(\mathrm{RWC}_{\mathrm{a}}\right)$ and leaf bulk modulus of elasticity $(\epsilon)$ of pomegranate plants in T0, T1 and T2 treatments at the end of the stress period. Means with the same letter across each row do not differ significantly according to Duncan's multiple range test $(P \leq 0.05)$.

\begin{tabular}{lrrr}
\hline Parameters & \multicolumn{1}{l}{ T0 } & \multicolumn{1}{c}{ T1 } & \multicolumn{1}{c}{ T2 } \\
\hline$\Psi_{\text {tlp }}(\mathrm{MPa})$ & $-2.50 \mathrm{a}$ & $-3.20 \mathrm{a}$ & $-3.63 \mathrm{a}$ \\
$\in(\mathrm{MPa})$ & $2.49 \mathrm{a}$ & $3.27 \mathrm{a}$ & $2.69 \mathrm{a}$ \\
$\mathrm{RWC}_{\text {tlp }}(\%)$ & $82.97 \mathrm{a}$ & $84.17 \mathrm{a}$ & $84.89 \mathrm{a}$ \\
RWC $_{\mathrm{a}}(\%)$ & $41.53 \mathrm{a}$ & $57.84 \mathrm{a}$ & $53.77 \mathrm{a}$ \\
\hline
\end{tabular}

values ( $146 \mathrm{mmol} \mathrm{m}^{-2} \mathrm{~s}^{-1}$ ) at the end of the stress period before recovering when irrigation was recommenced (Figs. 1B, F and 2). The $g_{\text {Imd }}$ values of $\mathrm{T} 1$ plants were intermediate between $\mathrm{T} 0$ and $\mathrm{T} 2$ values during the stress period (Fig. 2).

During the stress period, $\Psi_{1}$ values on the five measuring dates showed a similar diurnal pattern, reaching maximum values at predawn, decreasing very quickly early in the morning, regardless of the treatment, and attaining minimum values at around 08:00-10:00 h (Fig. 3). These minima remained almost constant to around $14: 00 \mathrm{~h}$, after which they recovered sharply (Fig. 3). At the end of the recovery period (DOY 250 ), the daily $\psi_{1}$ pattern was characterized by a gradual decrease, reaching minimum values at around $14: 00 \mathrm{~h}$ and then recovering rapidly in the afternoon. Differences between the $\Psi_{1}$ values of the three treatments gradually increased from DOY 217 to 243 (end of the stress period) when $\psi_{1}$ values were maximal in $\mathrm{T} 0$ and minimal in T2 plants throughout the day. At the end pf the recovery period (DOY 250 ), $\Psi_{1}$ values in T2 plants were similar to those in T0 plants, while in T1 plants, which continued under deficit irrigation, $\Psi_{1}$ values were lower than those in T0 and T2 plants from predawn to $14: 00 \mathrm{~h}$ (Fig. 3).

The circadian rhythm of $g_{1}$ values in T0 plants was characterized by maximum values at around 08:00-10:00 h on DOY 217, 236 , 243 and 250 as a consequence of stomata opening at sunrise and a second peak at around 13:00-16:00 h (Fig. 3). However, on DOY 226 and $231 g_{1}$ values were seen to fall slightly after the first peak. $\mathrm{T} 1$ and T2 plants did not showed a second $g_{1}$ peak, except on DOY 243, while T2 plants showed a tendency to shorten the duration of maximum stomatal opening as stress progressed. At the end of the recovery period (DOY 250), gl values in T2 plants were similar to those of T0 plants (Fig. 3)

On the last day of the stress period (DOY 243), no significant differences in $\Psi_{\text {tlp }}, \epsilon, \mathrm{RWC}_{\mathrm{a}}$ (which ranged from 42 to $58 \%$ ) or $\mathrm{RWC}_{\text {tlp }}$ values were observed between treatments (Table 1 ).

\section{Discussion}

Taking into account that $\Psi_{\text {pd }}$ values depend mainly on soil moisture levels (Elfving and Zhang, 1972; Sellin, 1996), the fact that $\Psi_{\text {pd }}$ values in T0 plants were high and nearly constant throughout the experimental period (Fig. 1A) indicated that the water supplied was sufficient. The differences observed in the plant water status of T0 and T1 plants (Figs. 1-3) suggested that the irrigation criteria used by the growers in the area (T1 treatment) did not satisfy pomegranate water requirements. For this reason, the T1 plants in our experimental conditions can be considered as being under deficit irrigation.

The rate of development of water stress in T2 plants was relatively low because the $\Psi_{\mathrm{pd}}$ values decreased by only around $0.02 \mathrm{MPa} \mathrm{d}^{-1}$ (Fig. 1A) (Hale and Orcutt, 1987). The existence of differences between $\Psi_{\text {pd }}$ and $\Psi_{\text {md }}$ values in T1 and T2 plants (Fig. 1A and B) suggested that under water stress the capacity of the conducting system to transport water was sufficient to allow some rehydration of leaves from noon onwards. The quick recovery of $\Psi_{\text {pd }}, \Psi_{\text {md }}$ and $\Psi_{\text {stem }}$ values in T2 when plants were rewatered
(Fig. 1A, B and F) has also been observed in other crops subjected to severe water stress (Torrecillas et al., 1995, 1996; Ruiz-Sánchez et al., 1997; Ortuño et al., 2006).

The decrease in $\psi_{\text {os }}$ values in T1 and T2 plants as a result of water stress ( 0.22 and $0.45 \mathrm{MPa}$, respectively) pointed to an active accumulation of osmotic solutes and, therefore, active osmotic adjustment in mature leaves of the pomegranate plants (Fig. 1E). These results agree with those observed in other woody crops such as peach (Steinberg et al., 1989; Arndt et al., 2000), apricot (Torrecillas et al., 1999), cherry (Ranney et al., 1991) and apple (Wang et al., 1995). In this sense, it has been shown that the ability to develop osmoregulation varies as a function of species and cultivar (Lakso, 1990; Torrecillas et al., 1996; Silva et al., 2009). Moreover, Arndt et al. (2000) indicated that active osmotic adjustment only occurs when water stress develops progressively, as in our experimental conditions, underlining the importance of field studies in which water stress is developed gradually over a prolonged period. The fact that $\psi_{\text {os }}$ values in T2 plants increased during the recovery period (Fig. 1E) may be related to the effect of a slight depletion of vacuolar solutes as a result of water stress (Ruiz-Sánchez et al., 1997).

The fact that leaf turgor was maintained in $\mathrm{T} 1$ and $\mathrm{T} 2$ plants before active osmotic adjustment occurred (Fig. 1C-E) suggests that the stomata regulation in $\mathrm{T} 1$ and $\mathrm{T} 2$ plants - characterized by a decrease in $g_{\text {Imd }}$ values, the absence of a second relative peak in $g_{1}$ values in its circadian rhythm and the tendency to shorten the duration of maximum stomatal opening as stress progressed (T2) (Figs. 2 and 3) - plays an active task in controlling leaf water status (Fig. 1). The decrease in stomatal conductance of woody crops leaves in response to drought stress has been reported as a primary response to water deficit, together with improved water use efficiency (Rieger and Duemmel, 1992; Girona et al., 1993).

The fast recovery of $g_{1 m d}$ values in T2 plants when irrigation was resumed could be due to the fact that, at the level of water stress reached on DOY 243, stomatal aperture is controlled directly only by a hydroactive mechanism (Torrecillas et al., 1995). A more severe water stress would probably have been necessary to trigger hormonal changes in leaves, such as an increase in abscisic acid and/or decrease in cytokinins, mechanisms that could have delayed stomatal aperture after rehydration (Mansfield, 1987; Davies and Zhang, 1991; Ruiz-Sánchez et al., 1997).

Although $\Psi_{\text {os }}$ has been seen to affect $\Psi_{\text {tlp }}$ (Sánchez-Blanco et al., 1991 ; Torrecillas et al., 1996) a different pattern in $\Psi_{\text {os }}$ and $\Psi_{\text {tlp }}$ was observed for pomegranate plants in our experimental conditions (Fig. 1E and Table 1), suggesting that the degree of active osmotic adjustment reached was not sufficient to modify the $\psi_{\text {tlp }}$ values.

Pomegranate plants did not develop elastic adjustment $(\epsilon$ decrease) as a result of water stress (Table 1). Moreover, the fact that $\mathrm{RWC}_{\mathrm{tlp}}$ values were similar in the three treatments (Table 1) confirmed that the $\epsilon$ controlled the $\mathrm{RWC}_{\mathrm{tlp}}$ values (Savê et al., 1995). In species which show osmoregulation, the maintenance of cell wall rigidity may be a prerequisite for maintaining cell tissue integrity upon rehydration following a period of stress (Clifford et al., 1998; Álvarez et al., 2009).

The $\mathrm{RWC}_{\mathrm{a}}$ values in pomegranate plants, which ranged from 42 to $58 \%$ (Table 1), were similar to those found for grapes (51-63\%) (Rodrigues et al., 1993) and to the lower limit of the range found for Pinus ponderosa (57-81\%) (Hardegree, 1989). However, pomegranate $\mathrm{RWC}_{\mathrm{a}}$ values were high compared with other tree species, such as Eucalyptus globulus (14-27\%) (Correia et al., 1989) and Quercus alba (26-31\%) (Parker and Pallardi, 1987). High RWC values is a common characteristic in xeromorphic plants (Cutler et al., 1977), being a consequence of thicker cell walls or differences in cell wall structure (Hellkvist et al., 1974), which could contribute to the retention of water at low leaf water potentials (Torrecillas et al., 1996). 

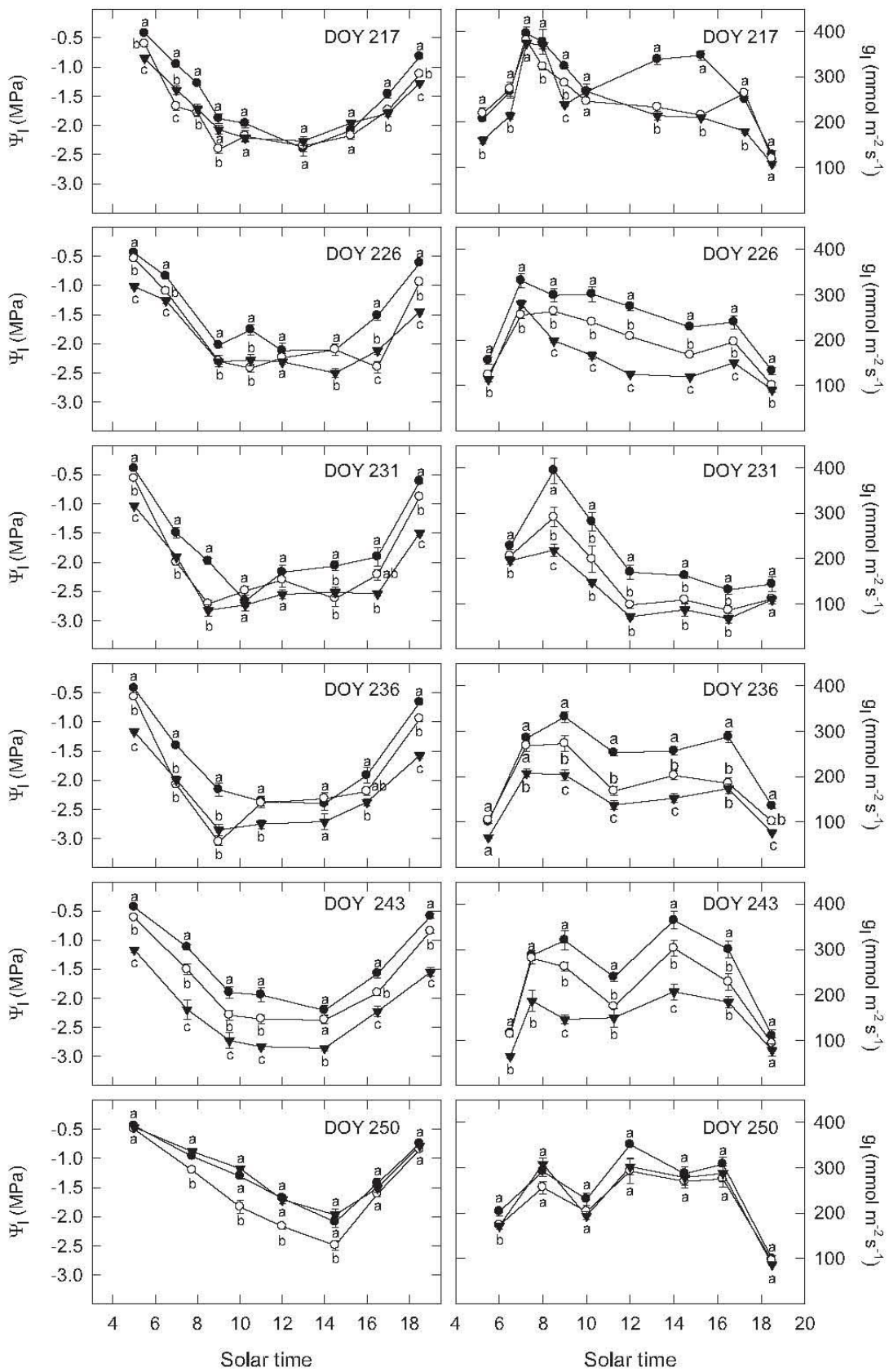

Fig. 3. Diurnal course of leaf water potential $\left(\Psi_{1}\right)$ and leaf conductance $\left(g_{1}\right)$ values (mean \pm SE, not shown when smaller than symbols, $n=4$ ) for pomegranate plants in T0, T1 and T2 treatments at five different times during the stress period (DOY 217, 226,231, 236 and 243) and at the end of the recovery period (DOY 250 ). Symbols as in Fig. 1.

The above results indicate that pomegranate plants confront water stress by developing stress avoidance and stress tolerance mechanisms. These mechanisms were seen to be complementary and take place gradually. From the beginning of deficit irrigation (T1) and water withholding (T2) leaf conductance decreased in order to control water loss via transpiration and avoid leaf turgor loss (stress avoidance mechanism). When, close to the end of the stress period, maximum stress levels were developed, active osmotic adjustment was triggered, which could have contributed to the maintenance of leaf turgor (stress tolerance mechanism). Furthermore, other drought tolerance characteristics were observed in pomegranate including high relative apoplastic water content.

\section{Acknowledgements}

This research was supported by Agencia Española de Cooperaciốn Internacional para el Desarrollo (AECID) (D/016779/08) and Ministerio de Ciencia e Innovaciôn (MICINN) (CICYT/FEDER 
AGL2010-19201-C04-01AGR) grants to the authors. C.D. Mellisho was research fellowship from MICINN (FPI). The authors also knowledge MICINN for the Ramón y Cajal contract of Dr. M.F. Ortuño.

\section{References}

Allen, R.G., Pereira, R.S., Raes, D., Smith, M., 1998. Crop EvapotranspirationGuidelines for Computing Crop Water Requirements. Irrigation and Drainage. FAO, Roma, p. 56.

Álvarez, S., Navarro, A., Bañón, S., Sánchez-Blanco, M.J., 2009. Regulated deficit irrigation in potted Dianthus plants: effects of severe and moderate water stress on growth and physiological res ponses. Sci. Hortic. 122, 579-585.

Amdt, S.K., Wanek, W., Clifford, S.C., Popp, M., 2000. Contrasting adaptations to drought stress in field-grown Ziziphus mauritania and Prunus persica trees: water relations, osmotic adjustment and carbon isotope composition. Aust J. Plan Physiol. 27, 985-996.

Aseri, G.K., Jain, N., Panwar, J., Rao, A.V., Meghwal, P.R., 2008. Biofertilizers improve plant growth, fruit yield, nutrition, metabolism and rhizosphere enzyme activities of Pomegranate (Punica granatum L.) in Indian Thar Desert. Sci. Hortic. 117, $130-135$.

Barrs, H.D., Weatherley, P.E., 1962. A re-examination of the relative turgidity technique for estimating water deficits in leaves. Aust. J. Biol. Sci. 15, 413-428.

Clifford, S.C., Arndt, S.K., Corlett, J.E., Joshi, S., Sankhla, N., Popp, M., Jones, H.G., 1998. The role of solute accumulation, osmotic adjustment and changes in cell wall elasticity in drought tolerance in Ziziphus mauritiana (Lamk). J. Exp. Bot. 49 967-977.

Collins, R., Kristensen, P., Thyssen, N., 2009. Water Resources Across Europe - Confronting Water Scarcity and Drought. European Environment Agency. Copenhagen, $57 \mathrm{pp}$.

Correia, M.J., Torres, F., Pereira, J.S., 1989. Water and nutrient supply regimes and the water relations of juvenile leaves of Eucalyptus globulus. Tree Physiol. 5 459-471.

Cutler, J.M., Rains, D.W., Loomis, R.S., 1977. The importance of cell size in the water relations of plants. Physiol. Plant. 40, 255-260.

Davies, W.J., Zhang, J., 1991. Root signals and regulation of growth and development of plants in drying soils. Ann. Rev. Plant Physiol. Plant Mol. Biol. 42, 55-76.

Elfving, D.C., Hall, A.E., Kaufmann, M.R., 1972. Interpreting leaf water potential mea-

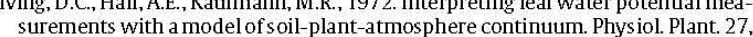
161-168.

Ephraim, P.L., Robert, A.N., 2007. Punica granatum (Pomegranate) and its potential for prevention and treatment of inflammation and cancer. J. Ethanopharmacol. $109,177-206$.

Fulton, A., Buchner, R., Olson, B., Schwankl, L., Giles, C., Bertagnia, N., Walton, J., Shackel, K, 2001. Rapid equilibration of leaf and stem water potential under field conditions in almond, walnuts and prunes. HortTechnology 11, 609-615.

Gimeno, V., Syvertsen, J.P., Nieves, M., Simón, I., Martínez, V., García-Sánchez, V., 2009. Additional nitrogen fertilization affects salt tolerance of lemon trees on different rootstocks. Sci. Hortic. 121, 298-305.

Girona, J., Mata, M., Goldhamer, D.A., Johnson, R.S., Dejong, T.M., 1993. Patterns of soil and tree water status and leaf functioning during regulated deficit irrigation scheduling in peach. J. Am. Soc. Hortic. Sci. 118, 580-586.

Hale, M.G., Orcutt, D.M., 1987. The Physiology of Plants Under Stress. Wiley, New York.

York.
Hardegree, S.P., 1989. Discrepancies between water potential isotherm measurements on Pinus ponderosa seedling shoots: xylem hysteresis and apoplasmic potentials. Plant Cell Environ. 12,57-62

Hellkvist, J., Richards, G.P., Jarvis, P.G., 1974. Vertical gradients of water potential and tissuewater relations in Sitka spruce trees measured with the pressure chamber. J. Appl. Ecol. 11, 637-667.

Holland, D., Hatib, K., Bar-Yàakov, I., 2009. Pomegranate: botany, horticulture, breeding. Hortic. Rev. 35, 127-191.

Janick, J., 2007. Fruits of the Bibles. HortScience 42, 1072-1076.

Kikuta, S.B., Richter, H., 1986. Graphical evaluation and partitioning of turgor responses to drought in leaves of durum wheat Planta $168,36-42$.

Lakso, A.N., 1990. Interactions of physiology with multiple environmental stresses in horticultural crops. HortScience 25, 1365-1369.

Levin, G.M., 2006. In: Bare, B.L. (Ed.), Pomegranate Roads: A Soviet Botanist's Exile from Eden, vol. 1. Floreat Press, Forestville, pp. 5-183.

Mansfield, T.A., 1987. Hormones as regulators of water balance. In: Davies, W.J. (Ed.) Plant Hormones and their Role in Plant Growth and Development. Martinus Nijhoff Publishers, Dordrecht, pp. 411-430.

Michel, D.S., Melanie, E.R.N., Gerdi, W., Jennifer, J.D., Mailine, H.C., Ruth, M., Caren, J., Raisin, R.N., Dean, O., 2005. Effect of pomegranate juice consumption on mycocardial perfusion in patient with coronary heart disease. Am. J. Cardiol. $96,810-814$

Ortuño, M.F., García-Orellana, Y., Conejero, W., Ruiz-Sánchez, M.C., Alarcón,J.J., Torrecillas, A., 2006. Stem and leaf water potentials, gas exchange, sap flow and trunk diameter fluctuations for detecting water stress in lemon trees. Trees 20 $1-8$.
Parker, W.C., Pallardi, S.G., 1987. The influence of resaturation method and tissue type on pressure-volume analysis of Quercus alba L, seedlings. J. Exp. Bot. 38 535-549.

Patakas, A., Noitsakis, B., 1999. Mechanisms involved in diurnal changes of osmotic potential in grapevines under drought conditions. J. Plant Physiol. 154 767-774.

Pereira, L.S., Cordery, I., Iacovides, I., 2002. Coping with Water Scarcity. Technical Documents in Hydrology, vol. 58. UNESCO, Paris

Prasad, R.N., Bankar, G.J., Vashishtha, B.B., 2003. Effect of drip irrigation on growth, yield and quality of pomegranate in arid region. Indian J. Hortic. 60, 140-142.

Ranney, T.G., Bassuk, N.L., Whitlow, T.H., 1991. Os motic adjustment and solute constituents in leaves and roots of water stressed cherry (Prunus) trees. J. Am. Soc. Hortic. Sci. 116, 684-688.

Rieger, M., Duemmel, M.J., 1992. Comparison of drought resistance among Prunus species from divergent habitats. Tree Physiol. 11, 369-380.

Rodrigues, M.L., Chaves, M.M., Wendler, R., Davis, M.M., Quick, W.P., Leegood, R.C. Stitt, M., Pereira, J.S., 1993. Osmotic adjustment in water stressed grapevine leaves in relation to carbon assimilation. Aust. J. Plant Physiol. 20,309-321.

Ruiz-Sánchez, M.C., Domingo, R., Savé, R., Biel, C., Torrecillas, A., 1997. Effects of water stress and rewatering on leaf water relations of lemon plants. Biol. Plant $39,623-631$

Sánchez-Blanco, M.J., Bolarín, M.C., Alarcôn,JJ.., Torrecillas, A., 1991. Salinity effects on water relations in Lycopersicon esculentum and its wild salt-tolerant relative species L. pennellii. Physiol. Plant. 83, 269-274.

Sánchez-Blanco, M.J. Rodríguez, P. Morales, M.A. Ortuño, M.F. Torrecillas, A., 2002 Comparative growth and water relations of Cistus albidus and Cistus monspelienComparative growth and water relations of Cistus albidus and Cistus m
sis plants during water deficit and recovery. Plant Sci. 162,107-113.

Savé, R., Biel, C., Domingo, R., Ruiz-Sánchez, M.C., Torrecillas, A., 1995. Some physiological and morphological characteristics of citrus plants for drought resistance Plant Sci. 110, 167-172.

Savé, R., Peñuelas, J., Marfá, O., Serrano, L., 1993. Changes in leaf osmotic and elastic properties and canopy architecture of strawberries under mild water stress. HortScience 28, 925-927.

Sellin, A., 1996. Base water potential of Picea abies as a characteristic of the soil water status. Plant Soil 184, 273-280.

Shackel, K., 2011. A plant-based approach to deficit Irrigation in trees and vines. HortScience 46, 173-177.

Shaliendra, A., Narendra, A., 2005. The effect of trickle irrigation on growth, yield and quality of pomegranate (Punica granatum) cv. Ganesh in Chhattisgarh region. Mysore J. Agr. Sci. 39, 175-181.

Silva, F.C.E., Shvaleva, A., Broetto, F., Ortuño, M.F., Rodrigues, M.L., Almeida, M.H Chaves, M.M., Pereira, J.S., 2009. Acclimation to short-term low temperatures in two Eucalyptus globulus clones with contras ting drought res istance. Tree Physiol. $29,77-86$.

SPPS Inc., 2002. SPSS Professional Statistics. Business Intelligence Division, v. 12 Chicago.

Steinberg, S.L., Miller Jr., J.C., McFarland, M.J., 1989. Dry matter partitioning and vegetative growth of young peach trees underwater stress. Aust. J. Plant Physiol. $17,23-36$.

Stover,E., Mercure,E.W., 2007. The pomegranate: a new look at the fruit of paradise HortScience 42, 1088-1092.

Sulochanamma, B.N., Yellamanda Reddy, T., Subbi Reddy, G., 2005. Effect of basin and drip irrigation on growth, yield and water use efficiency in pomegranate $\mathrm{cv}$. Gennesh. Acta Hortic. 696, 277-279.

Torrecillas, A., Alarcón, J.J., Domingo, R., Planes, J., Sánchez-Blanco, M.J., 1996. Strategies for drought resistance in leaves of two almond cultivars. Plant Sci. 118, gies for $135-143$.

Torrecillas, A., Galego, R., Pérez- Pastor, A., Ruiz-Sánchez, M.C., 1999. Gas exchange and water relations of young apricots plants under drought conditions. J. Agric Sci. $132,445-452$

Torrecillas, A., Guillaume, C., Alarcón, J.J., Ruiz-Sánchez, M.C., 1995. Water relations of two tomato species under water stress and recovery. Plant Sci. 105 169-176.

Torrecillas, A., Rodríguez, P., Sánchez-Blanco, M.J., 2003. Comparison of growth, leaf water relations and gas exchange of Cistus albidus and C. monspeliensis plants irrigated with water of different $\mathrm{NaCl}$ salinity levels. Sci. Hortic. 97, 353-368.

Turner, N.C., 1988. Measurement of plant water status by the pressure chamber technique. Irrig. Sci. 9, 289-308.

Tyree, M.T., Hammel, H.T., 1972. The measurement of the turgor pressure and the water relations of plants by the pressure-bomb technique. J. Exp. Bot. 23 , the water

Tyree, M.T., Richter, H., 1981. Alternative methods of analysing water potential isotherms: some cautions and clarifications, 1 . The impact of non-ideality and of some experimental errors. J. Exp. Bot. 32,643-653.

Tyree, M.T., Richter, H., 1982. Alternative methods of analysing water potentia isotherms: some cautions and clarifications, II. Curvilinearity in water potential isotherms. Can. J. Bot. 60,911-916.

Wang, Z., Quebedeaux, B., Stutte, G.W., 1995. Osmotic adjustment: effect of water stress on carbohydrates in leaves, stems and roots of apple. Aust. J. Plant Physiol $22,747-754$. 
Agricultural and Forest Meteorology 194 (2014) 29-35

Contents lists available at ScienceDirect

Agricultural and Forest Meteorology

journal homepage: www.elsevier.com/locate/agrformet

Rainfall intensifies fruit peel cracking in water stressed pomegranate trees

A. Galindo ${ }^{a}$, P. Rodríguez ${ }^{\text {b }}$ J. Collado-González ${ }^{\mathrm{a}}$, Z.N. Cruz ${ }^{\mathrm{b}}$, E. Torrecillas ${ }^{\mathrm{c}}$, S. Ondoño ${ }^{\mathrm{c}}$, M. Corell ${ }^{\mathrm{d}}$, A. Moriana ${ }^{\mathrm{d}}$, A. Torrecillas $\mathrm{s}^{\mathrm{a}, *}$

- Dpto. Riego, Centro de Edafologia y Biología Aplicada del Segura (CSIC), P.O. Box 164, E-30100 Espinardo, Murcia, Spain

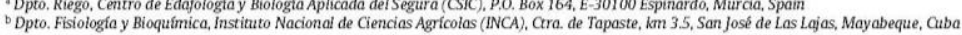

¿Dpto. Conservación de Suelos y Agua, Centro de Edafología y Biología Aplicada del Segura (CSIC), P.O. Box 164, E-30100 Espinardo, Murcia, Spai

¿Escuela Técnica Superior de Ingeniería Agronómica. Universidad de Sevilla, Carretera de Utrera, km 1, E-41013 Sevilla, Spain

\section{Methodology}

See page 60.

\section{Results}

The results indicated that during the end of fruit growth and ripening phases pomegranate fruit was clearly sensitive to water deficit. During these phenological periods water could enter the fruits via the phloem rather than via the xylem. Despite this, some treatment plants reached much more severe water stress levels than those reported in the literature, although leaf turgor was maintained. However, in all treatments fruit turgor was lost as a consequence of water stress, which induced a reduced expansion of fruits. When rainfall affected previously water stressed pomegranate plants an asymmetric increase in fruit turgor pressure took place, because aril turgor increased to a much greater extent than peel turgor, the pressure of the arils on the peel favouring cracking.

\section{Conclusions}

The observations suggest that pomegranate fruit during the end of fruit growth and ripening period was sensitive to water deficit. During these phenological periods water could enter the fruits via the phloem rather than via the xylem. Although leaf turgor was maintained during the very severe water stress, fruit turgor was lost, inducing the reduced expansion of fruits. When rainfall affected previously water stressed pomegranate plants an asymmetric increase in fruit turgor pressure took place, because aril turgor increased to a much greater extent than peel turgor. This increase in aril pressure would put pressure on the peel and make it susceptible to cracking. 


\title{
Rainfall intensifies fruit peel cracking in water stressed pomegranate trees
}

\author{
A. Galindo a , P. Rodríguez ${ }^{b}$, J. Collado-González ${ }^{a}$, Z.N. Cruz ${ }^{\text {, }}$, E. Torrecillas ${ }^{c}$, S. Ondoño ${ }^{c}$, \\ M. Corell ${ }^{\mathrm{d}}$, A. Moriana ${ }^{\mathrm{d}}$, A. Torrecillas ${ }^{\mathrm{a}, *}$ \\ a Dpto. Riego, Centro de Edafología y Biología Aplicada del Segura (CSIC), P.O. Box 164, E-30100 Espinardo, Murcia, Spain \\ ${ }^{b}$ Dpto. Fisiología y Bioquímica, Instituto Nacional de Ciencias Agrícolas (INCA), Ctra. de Tapaste, km 3.5. San José de Las Lajas, Mayabeque, Cuba \\ cDpto. Conservación de Suelos y Agua, Centro de Edafología y Biología Aplicada del Segura (CSIC), P.O. Box 164, E-30100 Espinardo, Murcia, Spain \\ d Escuela Técnica Superior de Ingeniería Agronómica. Universidad de Sevilla, Carretera de Utrera, km 1, E-41013 Sevilla, Spain
}

\section{A R T I C L E I N F O}

Article history:

Received 2 December 2013

Received in revised form 3 March 2014

Accepted 9 March 2014

\section{Keywords:}

Fruit water potential

Fruit water relations

Plant water relations

Punica granatum

Water stress

\begin{abstract}
A B S T R A C T
The purpose of the present study was to study the relationship between the leaf and fruit water relations of pomegranate plants at different water deficit levels during the end of the fruit growth and ripening phases. Moreover, special attention was paid to analysing whether the effect that rainfall has on peel cracking of pomegranate fruits growing in water deficit conditions is associated with changes in turgor within the fruit. For this, field-grown adult pomegranate trees (Punica granatum L.) cv. Mollar de Elche were subjected to five irrigation treatments. During the growing season, control plants (treatment T0) were irrigated above crop water requirements. During the experimental period (DOY 247-283), T1, T2, T3, and T4 treatments were irrigated as T0 except for 6 (DOY 277-283), 15 (DOY268-283), 25 (DOY258-283) and 36 (DOY247-283) days before harvest (DOY 283), respectively, when irrigation was withheld. Rain fell on DOY $270(3.5 \mathrm{~mm})$, DOY $271(84 \mathrm{~mm})$ and DOY $272(0.9 \mathrm{~mm})$, totalling $88.4 \mathrm{~mm}$. During the experiment, total ETo was $162 \mathrm{~mm}$, and the total amount of water received was $128,110,86,49$ and $0 \mathrm{~mm}$ for T0, T1, T2, T3 and T4, respectively, without considering precipitation. The results indicated that during the end of fruit growth and ripening phases pomegranate fruit was clearly sensitive to water deficit. During these phenological periods water could enter the fruits via the phloem rather than via the xylem. Despite this, T3 and T4 plants reached much more severe water stress levels than those reported in the literature, although leaf turgor was maintained. However, in all treatments fruit turgor was lost as a consequence of water stress, which induced a reduced expansion of fruits. When rainfall affected previously water stressed pomegranate plants an asymmetric increase in fruit turgor pressure took place, because aril turgor increased to a much greater extent than peel turgor, the pressure of the arils on the peel favouring cracking
\end{abstract}

(c) 2014 Elsevier B.V. All rights reserved.

\section{Introduction}

Pomegranate (Punica granatum L.) and P. protopunica are the two species that make up the Punicaceae family. P. protopunica, which is considered as the ancestrer of the genus (Shilikina, 1973), is generally accepted as being endemic of the Socotra Island (Yemen) and $P$. granatum, one of the earliest domesticated plant species, is believed to be a native to the southern Caspian belt (Iran) and northern Turkey (Janick, 2007).

\footnotetext{
* Corresponding author. Tel.: +34968 396330; fax: +34 968396213.

E-mail address: atorreci@cebas.csic.es (A. Torrecillas).
}

P. granatum has been regarded as a minor crop for a long time. However, the way pomegranate fruit is regarded has begun to change due to the crop's adaptation to a wide range of climates and soil conditions and increasing interest in of its fruits due to their organoleptic characteristics and perceived health benefits (Michel et al., 2005; Ephraim and Robert, 2007; Lansky and Newman, 2007).

Pomegranate fruits are complex in structure, showing a persistent calyx at the top of fruit, which is maintained until maturity and acts as a distinctive feature of these fruits. The fruit is technically a leathery-skinned and fleshy berry. The multi-ovule chambers (locules) are separated by membranous walls (septum) and fleshy mesocarp (Holland et al., 2009). The locules are filled with many seeds (arils) which comprise the edible portion of the fruit. The arils contain a juicy edible layer that develops entirely from the outer 
epidermal cells of the seed, which elongate to a very large extent in a radial direction (Fahan, 1976). The sap of these cells develops a turgor pressure that preserves the characteristic external shape of these cells (Holland et al., 2009). The husk comprises of two parts: the pericarp, which provides a cuticle layer and fibrous mat; and the mesocarp (also known as the albedo), which is the spongy tissue and inner fruit wall to which the arils are attached (Stover and Mercure, 2007).

Pomegranates are grown in very different climatic areas, but are frequent in areas predisposed to water scarcity (Holland et al., 2009). Studies on the water relations of pomegranate plants have mostly focused on the vegetative part of the plant, which possesses the drought tolerance characteristics that are common in xeromorphic plants, such as high leaf relative apoplastic water content and the ability to confront water stress by developing complementary stress avoidance and stress tolerance mechanisms (Rodríguez et al., 2012). For these reasons, this drought-hardy crop supports heat and thrives well in arid and semiarid areas, and even under desert conditions (Sarkhosh et al., 2006; Aseri et al., 2008). However, to the best of our knowledge, no information exists on pomegranate fruit water relations. In this sense, it is of paramount importance that one of the foremost physiological disorders, which has a severe economic impact on pomegranate fruit value, is the cracking of ripe fruit (Blumenfeld et al., 2000; Holland et al., 2009). Such defects seem to be directly related to fruit water status, because regular irrigation can decrease the damage (Prasad et al., 2003). Moreover, the conviction exists among growers that rain falling on mature pomegranate fruits following the end of the dry season can induce rapid fruit cracking (Holland et al., 2009), although no scientific evidence has been proposed for the mechanisms developed. For these reasons, the aim of the experiments described was to increase our understanding of the relationship between leaf and fruit water relations in pomegranate plants under different water deficit levels during the end of fruit growth and ripening phases. Moreover, special attention was paid to analysing whether the peel cracking caused by rainfall under water deficit conditions is associated with changes in turgor within the fruit.

\section{Materials and methods}

\subsection{Plant material, experimental conditions and treatments}

The experiment was carried out in 2012 in a farm located near the city of Alhama de Murcia (Spain) $\left(37^{\circ} 47^{\prime} \mathrm{N}, 1^{\circ} 25^{\prime} \mathrm{W}\right)$. The soil of the orchard is a moderately saline $\left(5.9 \mathrm{dS} \mathrm{m}^{-1}\right)$ Hyposalic Calciorthid, with a silt loam texture, moderate lime content ( $20 \%$ calcium carbonate), very low organic matter content (1.1\%), low cationic exchange capacity $\left(9.32\right.$ mequiv $\left.100 \mathrm{~g}^{-1}\right)$, and low available potassium and high available phosphorus levels.

The plant material consisted of own rooted adult pomegranate trees $(P$. granatum L.) cv. Mollar de Elche. Tree spacing followed a $3 \mathrm{~m} \times 5 \mathrm{~m}$ pattern. The irrigation water used had an electrical conductivity of between 0.9 and $1.3 \mathrm{dS} \mathrm{m}^{-1}$. The $\mathrm{Cl}^{-}$concentration in the irrigation water ranged from 67 to $78 \mathrm{mg} \mathrm{l}^{-1}$ during the experimental period. Pest control and fertilization practices were those usually used by local growers, and no weeds were allowed to develop within the orchard.

During the growing season, control plants (treatment T0) were irrigated above crop water requirements in order to ensure nonlimiting soil water conditions. Irrigation was performed daily during the night using a drip-irrigation system with a lateral pipe parallel to each tree row and 3 emitters per tree, each delivering $41 \mathrm{~h}^{-1}$. In-line water meters were used to measure the water supplied to each experimental unit. T1, T2, T3, and T4 treatments were irrigated as T0 except for 6 (DOY 277-283), 15 (DOY 268-283),
25 (DOY 258-283) and 36 (DOY 247-283) days before harvest (DOY 283), respectively, when irrigation was withheld. During the experimental period (DOY 247-283), total ETo (crop reference evapotranspiration) was $162 \mathrm{~mm}$, and the total amount of water received by each treatment was $128,110,86,49$ and $0 \mathrm{~mm}$ for T0, T1, T2, T3 and T4 treatments, respectively, without considering precipitation (basically the $84 \mathrm{~mm}$ that fell on DOY 271)

\subsection{Measurements}

Micrometeorological data, namely air relative humidity, air temperature, solar radiation, rainfall and wind speed $2 \mathrm{~m}$ above the soil surface, were collected by an automatic weather station located near the experimental site. Mean daily air vapour pressure deficit (VPD ${ }_{m}$ ) was calculated according to Allen et al. (1998), and daily crop reference evapotranspiration (ETo) was calculated using the Penman-Monteith equation (Allen et al., 1998).

The water relations of the leaves and fruits were measured at midday ( $12 \mathrm{~h}$ solar time). Fruits and fully expanded leaves from the south-facing side and middle third of the tree of four trees per treatment were selected for measurements. Midday leaf conductance $\left(g_{\text {leaf }}\right)$ was measured with a porometer (Delta T AP4, Delta-T Devices, Cambridge, UK) on the abaxial surface of two leaves per tree. Midday fruit water potential ( $\left.\psi_{\text {fruit }}\right)$, midday leaf water potential ( $\left.\Psi_{\text {leaf }}\right)$, and midday stem water potential $\left(\Psi_{\text {stem }}\right)$ were measured in two fruits or two leaves similar to those used for $g_{\text {leaf }}$ using a pressure chamber (PMS 600-EXP, PMS Instruments Company, Albany, USA) (McFadyen et al., 1996; Gelly et al. 2004; Dell'Amico et al., 2012). Leaves for $\psi_{\text {stem }}$ measurements were enclosed in a small black plastic bag covered with aluminium foil for at least $2 \mathrm{~h}$ before the measurements were made.

Midday leaf ( $\left.\Psi_{\pi \text { leaf }}\right)$, fruit juice ( $\left.\Psi_{\pi \text { arils }}\right)$ and fruit peel $\left(\Psi_{\pi \text { peel }}\right)$ osmotic potentials were determined in the same leaves and fruits as used for $\Psi_{\text {leaf }}$ and $\psi_{\text {fruit }}$ measurements. Leaves and fruits (peel and aril juice) were covered with aluminium foil and immediately frozen in liquid nitrogen and stored at $-80^{\circ} \mathrm{C}$. The osmotic potential was measured after thawing the samples and expressing the sap, using a vapour pressure osmometer (Wescor 5600, Logan, USA). Estimated midday leaf ( $\Psi_{\mathrm{p} \text { leaf }}$ ), fruit juice ( $\Psi_{\mathrm{p} \text { arils }}$ ) and fruit peel $\left(\Psi_{\text {p peel }}\right)$ turgor potentials were derived as the difference between osmotic and water potentials (Kaufmann, 1970; Milad and Shackel, 1992; Mills et al., 1997; Yamada et al., 2004).

Pomegranate fruits were harvested on 10 October (DOY 283) The mean weight of marketable and peel-cracked fruit was determined according to the weight and number of fruits per box in randomly selected boxes per replicate ( $2-4$ boxes).

\subsection{Statistical design and analysis}

The design of the experiments was completely randomized with four replications, each replication consisting of three adjacent rows, each with thirteen trees. Measurements were taken on the innermost tree of the central row of each replicate, which were very similar in appearance (leaf area, trunk cross sectional area, height ground shaded area, etc.), while the other trees served as border trees. Data were analysed using SPSS software (SPPS, 2002). Analyses of variance were performed and mean values were compared by an $\mathrm{LSD}_{0.05}$ test. Values for each replicate were averaged before the mean and the standard error of each treatment were calculated.

\section{Results}

During the experimental period, average daily maximum and minimum air temperatures were 28.0 and $14.8^{\circ} \mathrm{C}$, respectively. $\mathrm{VPD}_{\mathrm{m}}$ ranged from 0.33 to $1.87 \mathrm{kPa}$, and accumulated ETo was 


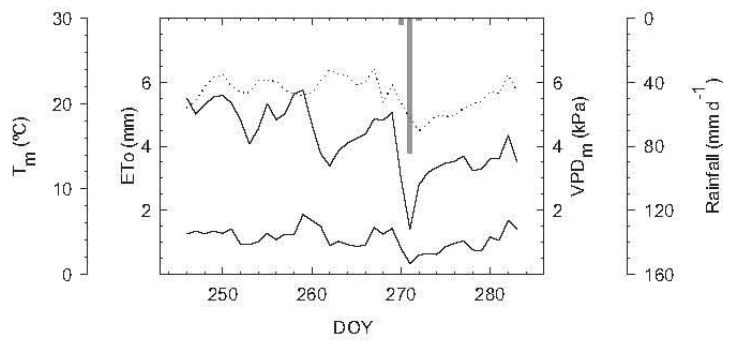

Fig. 1. Daily crop reference evapotranspiration (ETo, solid thick line), daily mean air temperature ( $T_{\mathrm{m}}$, dotted line), mean daily air vapour pressure deficit $\left(\mathrm{VPD}_{\mathrm{m}}\right)$ (solid thin line) and daily rainfall (vertical bars) during the experimental period.

$162 \mathrm{~mm}$ (Fig. 1). Total rainfall was $88.4 \mathrm{~mm}$ : DOY $270(3.5 \mathrm{~mm})$, DOY $271(84 \mathrm{~mm})$ and DOY $272(0.9 \mathrm{~mm})$ (Fig. 1).

The $g_{\text {leaf }}, \Psi_{\text {leaf }}, \Psi_{\text {stem }}$ and $\Psi_{\text {fruit }}$ values in T0 plants were relatively high and almost constant throughout the experimental period, and none was modified by the rainfall effect (Fig. 2). However, the $g_{\text {leaf }}, \Psi_{\text {leaf }}, \Psi_{\text {stem }}$ and $\Psi_{\text {fruit }}$ values in T3 and T4 plants gradually decreased from the beginning of their water withholding periods, the minimum values reached increasing after rainfall (Fig. 2). Despite the fact that in T2 rainfall occurred only three days after the water withholding period started (DOY 268), the gleaf $\Psi_{\text {stem }}$ and $\Psi_{\text {fruit }}$ values in these plants gradually decreased, while $\Psi_{\text {leaf }}$ values did not change between DOY 268 and 276 (Fig. 2). Moreover, $g_{\text {leaf }}, \Psi_{\text {leaf }}, \Psi_{\text {stem }}$ and $\Psi_{\text {fruit }}$ values in T1 plants gradually decreased throughout the experimental period (Fig. 2).

Minimum $g_{\text {leaf }}, \Psi_{\text {leaf }}, \Psi_{\text {stem }}$ and $\Psi_{\text {fruit }}$ values in T1 and T2 plants: 279 and $269 \mathrm{mmol} \mathrm{m}^{-2} \mathrm{~s}^{-1}$ (gleaf) $),-3.60$ and $-3.79 \mathrm{MPa}$ $\left(\Psi_{\text {leaf }}\right),-2.90$ and $-3.20 \mathrm{MPa}\left(\Psi_{\text {stem }}\right)$ and -3.27 and $-3.49 \mathrm{MPa}$ $\left(\psi_{\text {fruit }}\right)$, respectively, were reached on DOY 283 (Fig. 2). Minimum $g_{\text {leaf }}, \Psi_{\text {leaf }}, \Psi_{\text {stem }}$ and $\Psi_{\text {fruit }}$ values in T3 plants were reached on DOY 280, 268, 263 and 268 , respectively: of $187 \mathrm{mmol} \mathrm{m}^{-2} \mathrm{~s}^{-1}$ $\left(g_{\text {leaf }}\right),-4.21 \mathrm{MPa}\left(\Psi_{\text {leaf }}\right),-3.64 \mathrm{MPa}\left(\Psi_{\text {stem }}\right)$ and $-4.07 \mathrm{MPa}\left(\Psi_{\text {fruit }}\right)$ (Fig. 2). In T4 plants minimum $g_{\text {leaf }}, \Psi_{\text {leaf }}, \Psi_{\text {stem }}$ and $\Psi_{\text {fruit }}$ values were reached on DOY 268,260, 256 and 256, respectively, when these values were $90 \mathrm{mmol} \mathrm{m}^{-2} \mathrm{~s}^{-1}\left(g_{\text {leaf }}\right),-4.00 \mathrm{MPa}\left(\Psi_{\text {leaf }}\right)$, $-3.52 \mathrm{MPa}\left(\Psi_{\text {stem }}\right)$ and $-3.71 \mathrm{MPa}\left(\Psi_{\text {fruit }}\right)$ (Fig. 2$)$.

$\Psi_{\text {fruit }}$ values in the control (T0) and water stressed (T1, T2,T3 and T4) plants were always higher than the corresponding $\Psi_{\text {leaf }}$ values (Fig. $2 \mathrm{~B}$ and D), for which reason $\Delta \Psi\left(\Psi_{\text {leaf }}-\Psi_{\text {fruit }}\right)$ values in the five treatments were negative throughout the experimental period (Fig. 3). Significant differences between treatments were found on all the measurement days except the first day of the measurement period (DOY 246). Moreover, the $\Delta \Psi$ values were lower in water stressed plants than in T0 plants (Fig. 3).

Significant differences between treatments in $\Psi_{\pi}$ leaf values were scarce, even though $\Psi_{\pi \text { leaf }}$ values showed to a certain tendency to decrease in plants under water deficit (Fig. 4A). In this sense, $\Psi_{\pi \text { leaf }}$ Values in T4 plants were significantly lower than those in T0 plants on DOY 256 and 268, while in T3 plants the $\Psi_{\pi \text { leaf }}$ values were significantly lower than those of T0 and T4 plants on DOY 268 and $\Psi_{\pi \text { leaf }}$ values in T2 plants were significantly lower than those in the other treatments plants on DOY 283 (Fig. 4A).

$\Psi_{\pi \text { peel }}$ and $\Psi_{\pi}$ arils values in the different irrigation treatments were clearly higher than those of $\Psi_{\pi \text { leaf }}$ (Fig. 4A-C). $\Psi_{\pi}$ peel values in water stressed plants (T1, T2, T3 and T4) fell from the beginning of the corresponding water withholding periods and presented significant differences with respect to the values in TO plants (Fig. 4B). The $\Psi_{\pi \text { peel }}$ values in T3 and T4 plants increased after rainfall (Fig. 4B). The $\Psi_{\pi}$ arils values in all five treatments were nearly constant and very similar, because the only significant difference between treatments was evident at the end of the experiment
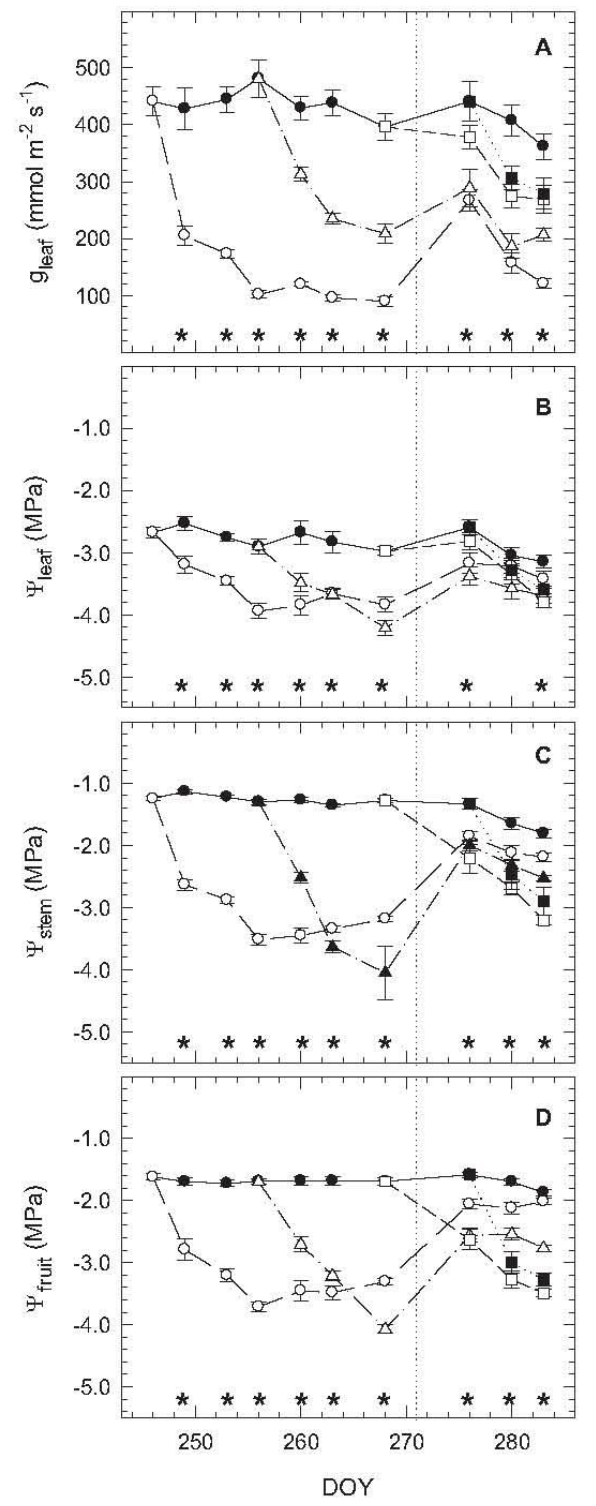

Fig. 2. Leaf conductance $\left(g_{\text {leaf }}, A\right)$, leaf water potential $\left(\Psi_{\text {leaf }}, B\right)$, stem water potential $\left(\Psi_{\text {stem }}, \mathrm{C}\right)$ and fruit water potential $\left(\Psi_{\text {fruit }}, \mathrm{D}\right)$ values (mean \pm SE, not shown when smaller than symbols, $n=4$ ) at midday for pomegranate plants in T0 (closed circles and solid line), T1 (closed squares and dotted line), T2 (open squares and short dash line), T3 (open triangles and dash dot line) and T4 (open circles and long short dash line), T3 (open triangles and dash dot line) and T4 (open circles and long
dash line) treatments during the experimental period. Vertical dashed line indicates the DOY 271 ( $84 \mathrm{~mm}$ of rainfall). Asterisks indicate significant differences between treatments according to $\mathrm{LSD}_{0,05}$ test.

(DOY 280 and 283) due to a decrease of $\Psi_{\pi \text { arils }}$ values in T0 plants (Fig. 4C).

Estimated $\Psi_{\text {p leaf }}$ values in the different treatments were nearly constant throughout the measurement period (Fig. 4D). Also, it is important to underline the fact that $\Psi_{\text {pleaf }}$ values in T1, $\mathrm{T} 2, \mathrm{~T} 3$ and T4 plants were significantly lower than those in T0 plants but always above zero (Fig. 4D). The peel and aril estimated turgor $\left(\Psi_{\text {p peel }}\right.$ and $\left.\Psi_{\text {parils }}\right)$ values remained practically unchanged in T0 plants during the experimental period, with the 


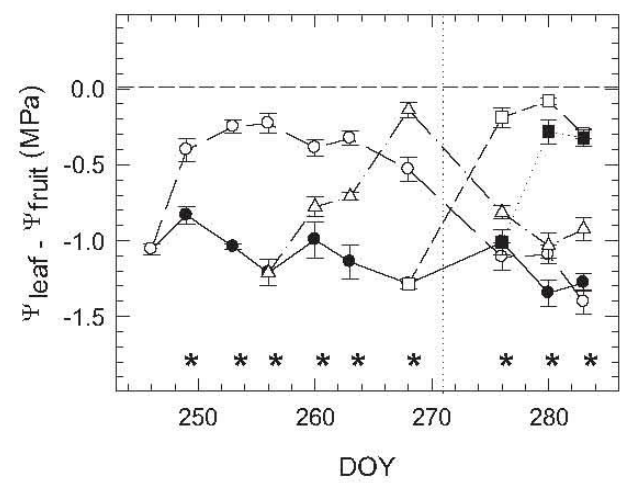

Fig. 3. Differences between midday leaf water potential $\left(\Psi_{\text {leaf }}\right)$ and midday fruit water potential $\left(\Psi_{\text {frut }}\right)$ values (mean \pm SE, not shown when smaller than symbols, $n=4$ ) for pomegranate plants in T0 (closed circles and solid line), T1 (closed squares and dotted line), T2 (open squares and short dash line), T3 (open triangles and dash dot line) and T4 (open circles and long dash line) treatments during the experimental period. Vertical dashed line indicates the DOY 271 ( $84 \mathrm{~mm}$ of rainfall). Asterisks indicate significant differences between treatments according to LSD0.05 test.

particular characteristic that the estimated turgor ( $\left.\Psi_{\text {parils }}\right)$ was higher and increased slightly at the end of the measurement period (Fig. 4F). The estimated $\Psi_{\mathrm{p} \text { peel }}$ and $\Psi_{\mathrm{p} \text { arils }}$ values in T1, T2, T3 and T4 plants achieved negative values as a consequence of the water stress (Figs. 4E and F). In T3 and T4 plants, rainfall resulted in a 1.1 -fold and 1.8 -fold average increase in the estimated $\Psi_{\text {p peel }}$ and $\Psi$ parils values, respectively, between the measurement before rainfall (DOY 268) and the measurement after rainfall (DOY 276)(Fig. 4E and F). It is also important to point out that after rainfall $\Psi_{\mathrm{p} \text { peel }}$ values in T3 and T4 plants, while remains above zero, were very low, whereas $\Psi_{\mathrm{p} \text { arils }}$ values were higher (Fig. 4E and F).

The $\Psi_{\text {fruit }}$ values in T0, T1, T2, T3 and T4 plants showed significant first-order correlations with $\Psi_{\text {leaf }}$ and $\Psi_{\text {stem. }}$. These equations
Table 1

Effect of irrigation treatments on total pomegranate fruit yield (TY, $\mathrm{kg} \mathrm{tree}^{-1}$ ), marketable pomegranate fruit yield (MY, $\mathrm{kg}^{\text {tree }}{ }^{-1}$ ), pomegranate fruit affected by peel craking (CY, kg tree ${ }^{-1}$ and \% respect to TY (in brackets)) and average marketable fruit weight (FW, g). Means within a column that do not have a common letter are significantly different by $\operatorname{LD}_{0.05}$ test.

\begin{tabular}{lllcc}
\hline Treatment & TY & MY & CY & FW \\
\hline T0 & $64.4 \mathrm{ab}$ & $56.8 \mathrm{a}$ & $7.6 \mathrm{c}(13.4)$ & $293 \mathrm{a}$ \\
T1 & $70.2 \mathrm{a}$ & $55.5 \mathrm{a}$ & $14.7 \mathrm{cb}(20.9)$ & $258 \mathrm{ab}$ \\
T2 & $55.0 \mathrm{~b}$ & $35.2 \mathrm{~b}$ & $19.8 \mathrm{~b}(28.2)$ & $252 \mathrm{~b}$ \\
T3 & $59.5 \mathrm{ab}$ & $28.9 \mathrm{~b}$ & $30.5 \mathrm{a}(51.2)$ & $249 \mathrm{~b}$ \\
T4 & $49.8 \mathrm{~b}$ & $17.8 \mathrm{~b}$ & $31.9 \mathrm{a}(64.1)$ & $253 \mathrm{~b}$ \\
\hline
\end{tabular}

indicated that the best predictor for $\Psi_{\text {fruit }}$ values was $\Psi_{\text {stem }}$ because the relation between both variables showed the highest coefficient of determination (Fig. 5).

The effect of a reduction in $\Psi_{\text {fruit }}$ on $\Psi_{\pi \text { peel }}, \Psi_{\pi \text { arils }}, \Psi_{\text {p peel }}$ and $\Psi_{\text {parils }}$ values is shown in Fig. $6 . \Psi_{\pi \text { peel }}$ values decreased linearly with the decrease in $\Psi_{\text {fruit }}$ values (Fig. 6A), whereas the $\Psi_{\pi \text { arils }}$ values did not change significantly with $\Psi_{\text {fruit }}$ (Fig. 6B). In both the arils and the peel, estimated turgor pressure ( $\Psi_{\text {p peel }}$ and $\left.\Psi_{\text {parils }}\right)$ also decreased linearly with a decrease in $\psi_{\text {fruit }}$. For a given change in $\Psi_{\text {fnuit }}$ values, the decrease in turgor pressure in the arils ( $\Psi_{\text {p arils }}$ ) was greater than in the peel $\left(\Psi_{\text {p peel }}\right)$. However, $\Psi_{\text {p peel }}$ reached the turgor loss point (values below zero) at higher $\Psi_{\text {fruit }}$ values $(-2.25 \mathrm{MPa})$ than $\psi_{\mathrm{p}}$ arils $(-2.69 \mathrm{MPa})$ (Fig. $6 \mathrm{C}$ and D).

The irrigation treatments produced a significant effect in the quantity and quality of the yield (Table 1). Total pomegranate yield was reduced significantly for the water restriction effect (Table 1). $\mathrm{T} 1$ plants showed higher yield than T2 and T4 plants but similar to T0 and T3 plants. Marketable fruit yield was similar in T2, T3 and T4 treatments but significantly lower than in T0 and T1 treatments, which were similar between them (Table 1). Harvested pomegranate fruits affected by peel cracking were significantly higher in treatment plants with longer water withholding periods (T3 and T4) and lower in T0 plants, whereas T2 plants showed intermediate values and similar to T1 plants, which at the same time

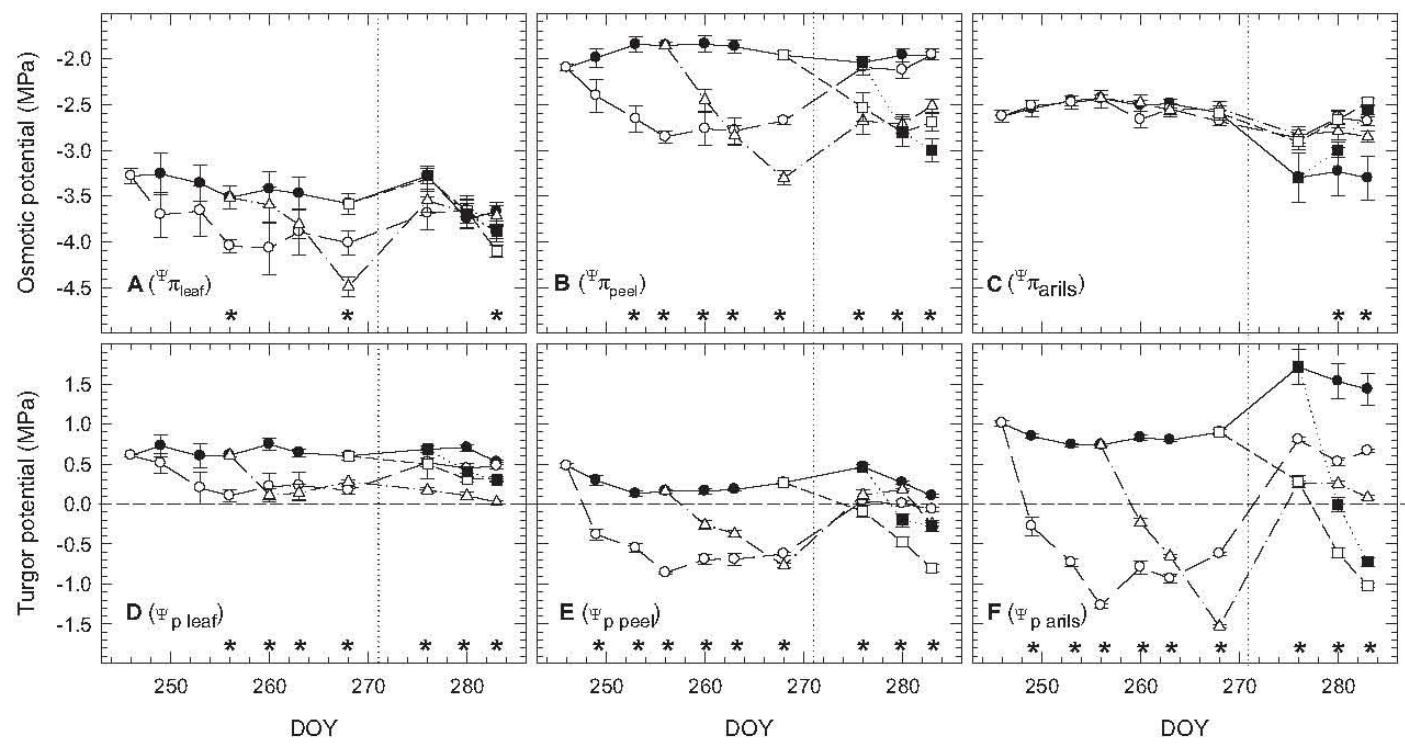

Fig. 4. Midday leaf osmotic potential $\left(\Psi_{\pi \text { leaf }}, \mathrm{A}\right)$, midday peel osmotic potential $\left(\Psi_{\pi \text { peel }}, \mathrm{B}\right)$, midday arils osmotic potential $\left(\Psi_{\pi \text { arlls }}, \mathrm{C}\right)$, midday leaf turgor potential $\left(\Psi_{\text {pleaf }}\right.$, D), midday peel turgor potential ( $\Psi_{\text {p peel }}$, E) and midday arils turgor potential ( $\Psi_{\mathrm{p} \text { arlls }}, \mathrm{F}$ ) values (mean $\pm \mathrm{SE}$, not shown when smaller than symbols, $\left.n=4\right)$ for pomegranate plants in T0 (closed circles and solid line), T1 (closed squares and dotted line), T2 (open squares and short dash line), T3 (open triangles and dash dot line) and T4 (open circles and long dash line) treatments during the experimental period. Vertical dashed line indicates the DOY 271 ( 84 mm of rainfall). Asterisks indicate significant differences between treatments according to LSD0.05 test. 


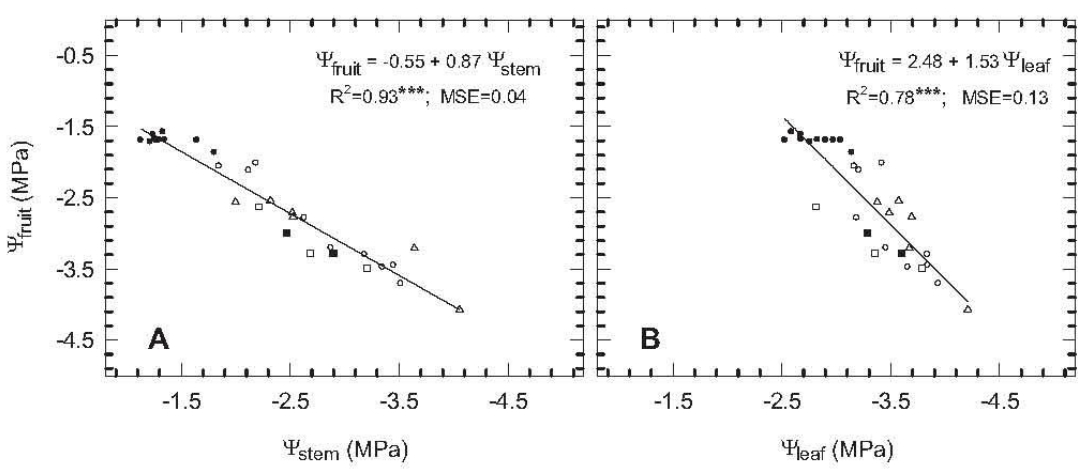

Fig. 5. Relationships for pomegranate plants under T0 (closed circles), T1 (closed squares), T2 (open squares), T3 (open triangles) and T4 (open circles) conditions between midday fruit water potential $\left(\Psi_{\text {fruit }}\right)$ and midday stem water potential $\left(\Psi_{\mathrm{stem}}, \mathrm{A}\right)$ and midday leaf water potential $\left(\Psi_{\text {leaf }}\right.$ B) using all data pooled. Each data point is the mean of four values.

were statistically similar to T0 plants (Table 1 ). Moreover, fruits from T2, T3 and T4 plants showed a significantly lower fruit size than fruits from T0 plants (Table 1). T1 fruits showed an intermediate response with no significant differences respect to T0 and T2, T3 and T4 (Table 1).

\section{Discussion}

The fact that $g_{\text {leaf }}, \Psi_{\text {leaf }}, \Psi_{\text {stem }}$ and $\Psi_{\text {fruit }}$ values in T0 plants were relatively high and almost constant throughout the experimental period and the fact that these values were not modified by the important rainfall that occurred on DOY 271 (Figs. 1 and 2) suggested that the irrigation applied to this treatment was sufficient to avoid any water deficit during the measurement period.

Although the lengths of the water withholding periods applied in the different treatment were clearly different, the minimum $g_{\text {leaf }}$ $\Psi_{\text {leaf }}, \Psi_{\text {stem }}$ and $\Psi_{\text {fruit }}$ values for each treatment (maximum stress values) grouped the treatments into two groups. On the one hand T3 and T4, in which plants reached very low $\Psi_{\text {leaf }}, \Psi_{\text {stem }}$ and $\Psi_{\text {fruit }}$ values and showed a substantial degree of stomatal regulation (Fig. 2) and on the other hand, T1 and T2, in which the $\Psi_{\text {leaf }}, \Psi_{\text {stem }}$ and $\Psi_{\text {fruit }}$ values were not so low as T3 and T4 plants and stomatal regulation was more moderate (Fig. 2). Moreover, taking into consideration previous papers (Mellisho et al., 2012; Rodríguez et al., 2012; Mena et al., 2013) the group T3 and T4 plants represented a very severe water deficit while the group consisting of $\mathrm{T} 1$ and $\mathrm{T} 2$ plants represented a more moderate but still severe water deficit situation.

The absence of movement of water from fruit to leaves, which are the main sites of transpiration, resulted in $\Psi_{\text {fruit }}$ values remaining above $\Psi_{\text {leaf }}$ values throughout the measurement period (Mills et al., 1997) (Figs. 2B and D and 3). This behaviour has also been observed in other crops, such as apple (Lang, 1990; Mills et al., 1997; Ward and Marini, 1999), Asian pear (Behboudian et al., 1994).
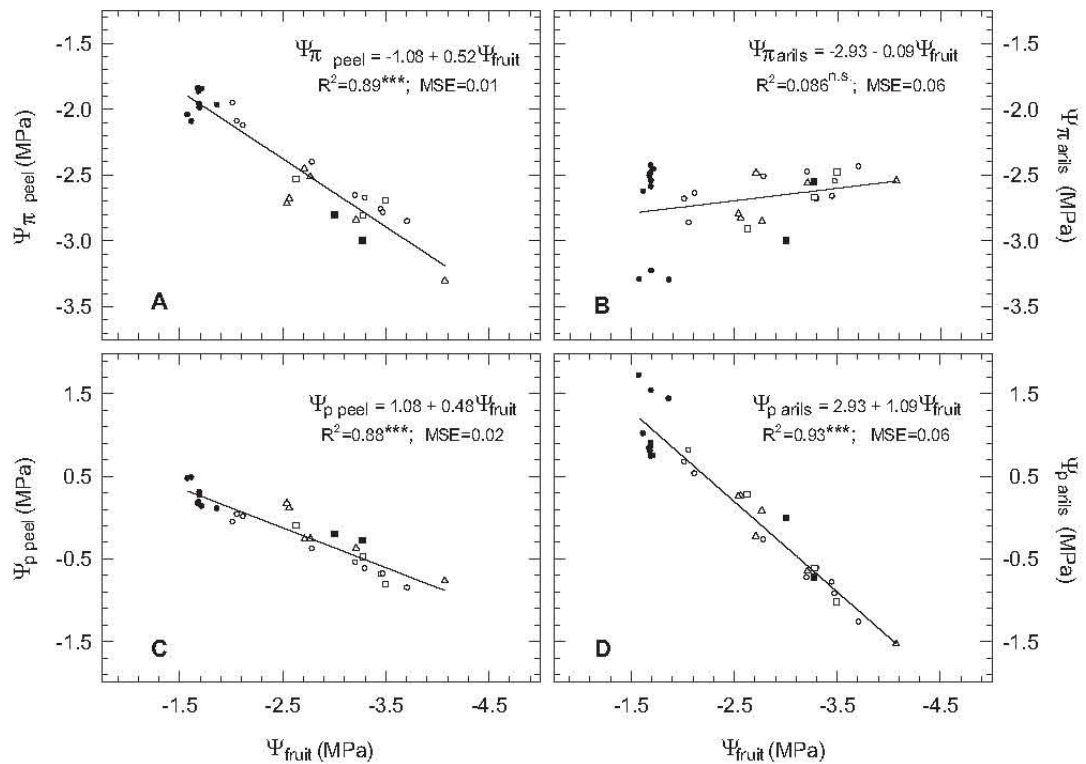

Fig. 6. Relationships for pomegranate plants under T0 (closed circles), T1 (closed squares), $\mathrm{T} 2$ (open squares), T3 (open triangles) and T4 (open circles) conditions between midday fruit water potential $\left(\Psi_{\text {fruit }}\right)$ and midday peel osmotic potential $\left(\Psi_{\pi \text { peel }}, \mathrm{A}\right)$, midday arils osmotic potential $\left(\Psi_{\pi}\right.$ arils,, , midday peel turgor potential $\left(\Psi_{\text {p peel }}, \mathrm{C}\right)$ and midday arils turgor potential $\left(\Psi_{\mathrm{p} \text { arlls }}, \mathrm{D}\right)$ using all data pooled. Each data point is the mean of four values. 
avocado (Blanke and Whiley, 1995), citrus (Syvertsen and Albrigo, 1980), cotton (Trolinder et al., 1993; Inglese et al., 1994), platyopuntias (Nobel and de la Barrera, 2000) and tomato (Ho et al., 1987). Whatever the case, from the energetic point of view, water cannot flow from leaves to the fruits, since the xylem is not the provider of water for fruits (Nobel et al., 1994; Nobel and de la Barrera, 2000). Consequently, during the experimental period, water might have entered the pomegranate fruits via the phloem rather via the xylem. In fully irrigated prunes other authors have suggested that the relative importance of xylem and phloem in the water flow to the fruit may be reversible (Matthews and Shackel, 2005). Greenspan et al. $(1994,1996)$ suggested that the bulk vascular water flow changes from xylem in pre-veraison to phloem in post-veraison in fully irrigated grape berry. Also, Dell'Amico et al. (2012) showed that water flow in olive fruit during pit hardening in fully irrigated conditions is via both xylem and phloem.

Although both T3 and T4 plants suffered much more severe water stress levels than has been described in the literature (Intrigliolo et al., 2011a,b; Rodríguez et al., 2012; Galindo et al., 2013), leaf turgor was maintained (Fig. 4D). Rodríguez et al. (2012) indicated that pomegranate plants confront water stress mainly by developing complementary stress avoidance and stress tolerance mechanisms. From the beginning of the water deficit treatments, leaf conductance decreased in order to limit water loss via transpiration and avoid leaf turgor loss (stress avoidance mechanism) (Figs. 2A and 4D). When important water stress levels had been reached active osmotic adjustment was triggered, which could have contributed to the maintenance of leaf turgor (stress tolerance mechanism) (Fig. 4D).

The fact that $\Psi_{\text {stem }}$ acted as a better $\Psi_{\text {fruit }}$ predictor than $\Psi_{\text {leat }}$ (Fig. 5) agrees with the results obtained in peach by Gelly et al. (2004), who also found that $\Psi_{\text {fruit }}$ measurements showed considerable consistency, and were more stable than other water potential assessments such as $\Psi_{\text {stem }}$ and predawn leaf water potential.

The estimate of turgor potential in different fruit positions can be made assuming that the $\Psi_{\text {fruit }}$ is very similar throughout the fruit (Milad and Shackel, 1992; Yamada et al., 2004). The fact that water deficit did not affect $\Psi_{\pi}$ arils values while $\Psi_{\pi}$ peel values significantly decreased in water deficit conditions (Fig. $4 \mathrm{~B}$ and C) may be related with the idea that changes in pomegranate fruit water status have a greater effect on water relations of the fruit peel than of the arils, which being located within the fruit, are to certain extent isolated by the coating cuticle. This idea agrees with the fact that pomegranate peel turgor loss was reached at higher $\Psi_{\text {fruit }}$ values than in arils (Fig. 6C and D), confirming the higher sensitivity of pomegranate peel to water stress.

The fact that T1 plants showed similar total and marketable fruit yield and average marketable fruit weight to T0 plants(Table 1) may be explained by the observation that $\mathrm{T} 1$ fruits lost turgor only for a very short period of time (less than 6 days) (Fig. $4 \mathrm{E}$ and F). The decrease in the marketable yield and size in T2, T3 and T4 fruits compared with T0 fruits (Table 1) can be attributed to the fact that in T2, T3 and T4 treatments fruit turgor was lost as a consequence of water stress (Fig. 4E and F), and expansive cell growth requires the presence of cell turgor because a direct relation between turgor and growth has been found in most of cases (Serpe and Matthews, 2000: Matthews and Shackel, 2005). The reduction in fruit expansion due to water stress may be completely recovered by a phase of accelerated growth following the relief of stress (Cleland, 1971). The fact that T3 and T4 fruit size did not recover even though fruit turgor recovered following rainfall could be due to the fact that 12 days was not sufficient time for fruit to attach a similar size to T0 fruits.

Some authors have indicated that under water stress peel mechanical properties change, the peel extensibility tending to decline (Matthews et al., 1987; Aloni et al., 1999) and becoming thicker and stiffer (Lawlor and Leach, 1985). These changes could explain the susceptibility of the T2, T3 and T4 pomegranate fruits to cracking. However, another and probably complementary mechanism should be taken into consideration. When rainfall affected previously water stressed pomegranate plants (T3 and T4) there was an asymmetric increase in fruit turgor pressure because $\psi_{\mathrm{p}}$ arils values increased to a much greater extent than $\Psi_{\text {p peel }}$ values (Fig. $4 \mathrm{E}$ and F), so that the pressure of the arils on peel could favour cracking.

In conclusion, our observations suggest that pomegranate fruit during the end of fruit growth and ripening period was sensitive to water deficit. During these phenological periods water could enter the fruits via the phloem rather than via the xylem. Although leaf turgor was maintained during the very severe water stress, fruit turgor was lost, inducing the reduced expansion of fruits. When rainfall affected previously water stressed pomegranate plants an asymmetric increase in fruit turgor pressure took place, because aril turgor increased to a much greater extent than peel turgor. This increase in aril pressure would put pressure on the peel and make it susceptible to cracking.

\section{Acknowledgements}

This research was supported by Agencia Española de Cooperaciôn Internacional para el Desarrollo (AECID) (A1/035430/11) and Ministerio de Ciencia e Innovaciốn (MICINN) (CICYT/FEDER AGL2010-19201-C04-01AGR) grants to the authors. AG and JCG were funded by a FPU and a FPI grant from the Spanish government, respectively.

\section{References}

Allen, R.G., Pereira, R.S., Raes, D., Smith, M., 1998. Crop evapotranspirationguidelines for computing crop water requirements. FAO Irrigation and Drainage Paper No 56, Rome, Italy, pp. 15-27.

Aloni, B., Karni, L., Moreshet, S., Yao, C., Stanghellini, C., 1999. Cuticular cracking in bell pepper fruit: II. Effects of fruit water relations and fruit expansion. J. Hort. Sci. Biotech. 74, 1-5.

Aseri, G.K., Jain, N., Panwar, J., Rao, A.V., Meghwal, P.R., 2008. Biofertilizers improve plant growth, fruit yield, nutrition, metabolism and rhizosphere enzyme activities of pomegranate (Punica gromatum L) in Indian Thar Desert. Sci. Hort. 117, $130-135$

Behboudian, M.H., Lawes, G.S., Griffths, K.M., 1994. The influence of water deficit on water relations, photosynthesis and fruit growth in Asian pear (Pyrus serotino Rehd.) Sci. Hort 60,89-99.

Blanke, M.M. Whiley. A.W. 1995. Bioenergetics, respiration costand water relations of developing avocado fruit. J. Plant Physiol. 145, 87-92.

Blumenfeld, A., Shaya, F., Hillel, R., 2000. Cultivation of Pomegranate CIHEAM: Options Méditerranées. http://ressources.ciheam.org/om/pdf/a42/ 00600264.pdf

Cleland, R.E., 1971. Cell wall extension. Annu. Rev. Plant Physiol. 22, 197-222.

Dell'Amico, J., Moriana, A., Corell, M., Girón, I.F., Morales, D., Torrecillas, A., Moreno, F., 2012. Low wáter stress conditions in table olive tres (Olea europea L.) during pit hardening produced a different response of fruit and leaf water relations Agric. Water Manage. 114, 11-17.

Ephraim, P.L., Robert, A.N., 2007. Punica granatum (Pomegranate) and its potentia for prevention and treatment of inflammation and cancer. J. Ethanopharmacol. 109, 177-206.

Fahan, A., 1976. The leaf, the flower, the seed. In: Plant Anatomy. Hakkibutz Hameuhad Publi., Jerusalem, pp. 171-172, 321-394, 419-430

Galindo A Rodríguez P. Mellisho, C.D. Torrecillas, E. Moriana, A. Cruz Z N., Conejero, W., Moreno, F., Torrecillas, A., 2013. Assessment of discretely measured indicators and maximum daily trunk shrinkage for detecting water stress in pomegranate trees. Agric. For. Meteorol. 180,58-65

Gelly, M., Marsal, J., Mata, M., Arbonés, A., Rufat, J., Girona, J., 2004. Fruit wate potential: a comparative study with other wáter potential parameters. Acta Hort. 646, 35-40.

Greenspan, M.D., Schultz, H.R., Matthews, M.A., 1996. Field evaluation of water transport in grape during water deficits. Physiol. Plant 97,55-62.

Greenspan, M.D., Shackel, K.A., Matthews, M.A., 1994. Developmental changes in the diurnal water budget of the grape berry exposed to water deficits. Plant Cell Environ. 17, 811-820.

Ho, L.C., Grange, R.I., Picken, A.J., 1987. An analysis of the accumulation of water and dry matter in tomato fruit. Plant Cell Environ. 10,157-162.

Holland, D.,Hatib, K. Bar-Yàakov, I.,2009. Pomegranate: botany, horticulture, breed ing. Hortic. Rev. 35, 127-191. 
Inglese, P., Israel, A.A., Nobel, P.S., 1994. Growth and $\mathrm{CO}_{2}$ uptake for cladodes and fruit of the Crassulacean acid metabolism species Opuntia ficus-indica during fruit development. Physiol. Plant. 91, 708-714.

Intrigliolo, D.S., Nicolás, E., Bonet, L., Ferrer, P., Alarcôn,J.J., Bartual, J., 2011a. Water relations of field grown pomegranate trees (Punica granatum) under different drip irrigation regimes. Agric. Water Manage. 98, 691-696.

Intrigliolo, D.S., Puerto, H., Bonet, L., Alarcón, J.J., Nicolás, E., Bartual, J., 2011b. Usefulness of trunk diameter variations as a continuous water stress indicators of pomegranate (Punica granatum) trees. Agric. Water Manage. 98, 1462-1468.

Janick, J., 2007. Fruits of the Bibles. HortScience 42, 1072-1076.

Kaufmann, M.R., 1970. Water potential components in growing citrus fruits. Plant Physiol. 46, 145-149.

Lang, A., 1990. Xylem, phloem and transpiration flows in developing apple fruits. J. Exp. Bot. 41, 645-651.

Lansky, E.P., Newman, R.A., 2007. Review: Punica granatum (pomegranate) and its potential for prevention and treatment of inflammation and cancer. J. Ethnopharm. 109, 177-206.

Lawlor, D.W., Leach, J.E., 1985. Leaf growth and water deficits: biochemistry in relation to biophysics. In: Baker, N.R., Davies, W.J., Ong, C.K. (Eds.), Control of Leaf Growth. Soc. Expt. Biol. Seminar Ser. 27, Cambridge Univ. Press, Cambridge, pp. Growth. Soc

Matthews, M.A., Cheng, G., Weinbaum, S.A., 1987. Changes in water potential and dermal extensibility during grape berry development. J. Amer. Soc. Hort. Sci.
$112,314-319$ $112,314-319$

Matthews, M.A., Shackel, K.A., 2005. Growth and water transport in fleshy fruit. In: Holbrook, N.M., Zwieniecki, M.A. (Eds.), Vascular Transport in Plants. Elsevier, Boston, pp. 181-197.

McFadyen, LM., Hutton, R.J., Barlow, E.W.R., 1996. Effects of crop load on fruitwater relations and fruit growth in peach. J. Hort. Sci. 71, 469-480

Mellisho, C.D., Egea, I., Galindo, A., Conejero, W., Rodríguez, P., Rodríguez, J., Romojaro, F., Torrecillas, A., 2012. Pomegranate (Punica granatum L.) fruit res ponse to different deficit irrigation conditions. Agric. Water Manage. 114, 30-36.

Mena, P., Galindo, A., Collado-González, J., Ondoño, S., García-Viguera, C., Ferreres, F., Torrecillas, A., Gil-Izquierdo, A., 2013. Sustained deficit irrigation affects the colour and phytochemical characteristics of pomegranate juice. J. Sci. Food Agric. 93, 1922-1927.

Michel, D.S., Melanie, E.R.N., Gerdi, W., Jennifer, J.D., Mailine, H.C., Ruth, M., Caren, J., Raisin, R.N., Dean, 0., 2005. Effect of pomegranate juice consumption on mycocardial perfusion in patient with coronary heart disease. Am. J. Cardiol. $96,810-814$.

Milad, R.E., Shackel, K.A., 1992. Water relations of fruit end cracking in French prune (Prunus domestica L. cv. French). J. Am. Soc. Hort. Sci. 117, 824-828.

Mills, T.M., Behboudian, M.H., Clothier, B.E., 1997. The diumal and seasonal water relations, and composition, of 'Braeburn' apple fruit under reduced plant water status. Plant Sci. 126, 145-154.

Nobel, P.S., Andrade, J.L, Wang, N., North, G.B., 1994. Water potential for developing cladodes and fruits of a succulent plant, including xylem-versus-floem implications for water movement J. Exp. Bot. 45, 1801-1807.

Nobel, P.S., de la Barrera, E., 2000. Carbon and water balances for young fruits of platyopuntias. Physiol. Plant. 109, 160-166.

Prasad, R.N., Bankar, G.J., Vashishtha, B.B., 2003. Effect of drip irrigation on growth, yield and quality of pomegranate in arid region. Indian J. Hortic 60, 140142

Rodríguez, P., Mellisho, C.D., Conejero, W., Cruz, Z.N., Ortuño, M.F., Galindo, A., Torrecillas, A., 2012. Plant water relations of leaves of pomegranate trees under different irrigation conditions. Environ. Exp. Bot. 77, 19-24.

Sarkhosh, A. Zamani, Z., Fatahi, R., Ebadi, A., 2006. RAPD markers reveal polymorphism among some Iranian pomegranate (Punica granatum L.) genotypes. Sci.

Serpe, M.D., Matthews, M.A., 2000. Turgor and cell wall yielding in dicot leaf growth in response to changes in relative humidity. Aust. J. Plant Physiol. 27, 1131-1140. Shilikina, I.A., 1973. On the xylem anatomy of the genus Punica L. Bot Z. 58 , $1628-1630$.

SPSS Inc., 2002. SPSS Professional Statistics. Business Intelligence Division, v. 12,

Chicago.
Stover, E., Mercure,E.W., 2007. The pomegranate: a new look at the fruit of paradise. HortSci 42, 1088-1092.

Syvertsen, J.P., Albrigo, L.G., 1980. Seasonal and diurnal Citrus leaf and fruit water relations. Bot. Gaz. 141, 440-446.

Trolinder, N.L., McMichael, B.L., Upchurch, D.R., 1993. Water relations of cotton flower petals and fruit. Plant Cell Environ. 16, 755-760.

Yamada, H., Takechi, K., Hoshi, A., Amano, S., 2004. Comparison of water relations in watercored and non-watercored apples induced by fruit temperature treatment. Sci. Hort. 99, 309-318

Ward, D Marini, RP. 1999. Growthand development of young apple fruits following applications of ethephon plus carbaryl for thinning. HortScience 34, 1057-1059. 
Agricultural and Forest Meteorology 180 (2013) $58-65$

Contents lists available at SciVerse Science Direct

Agricultural and Forest Meteorology

\section{Methods}

See pages 68 and 69.

\section{Results}

Maximum daily trunk shrinkage (MDS) was identified to be the most suitable plant-based indicator for irrigation scheduling in adult pomegranate trees, because its signal:noise ((T1/T0):coefficient of variation) ratio was higher than that for $\Psi_{\text {stem }}$ ((T1/T0):coefficient of variation) and $g_{।}$ ((T0/T1):coefficient of variation). MDS increased in response to water stress, but when the $\Psi_{\text {stem }}$ fell below -1.67 MPa, the MDS values decreased. For non-limiting water conditions, MDS could be predicted from mean daily air temperature $\left(T_{m}\right)$ through exponential equations fitted to pooled data across several seasons. First-order equations were also obtained by pooling data across several seasons to predict MDS from crop reference evapotranspiration (ETo), mean daily air vapour pressure deficit $\left(\mathrm{VPD}_{\mathrm{m}}\right), \mathrm{Tm}$ and solar radiation $\left(\mathrm{R}_{\mathrm{s}}\right)$, but these should be used only within a certain range of values (ETo, 2.1-7.4 mm; VPD $0.64-2.96 \mathrm{kPa} ; \mathrm{T}_{\mathrm{m}}, 12.1-28.3 \stackrel{\circ}{\circ} \mathrm{C} ; \mathrm{R}_{\mathrm{s}}, 119.4-331.3 \mathrm{Wm}^{-2}$ ). Hence, automated MDS measurements have the potential to be used in irrigation scheduling of pomegranate, and these values can be normalized to non-limiting water conditions by locally derived empirical relationships with meteorological variables.

\section{Conclusions}

MDS is a reliable plant-based water stress indicator in adult pomegranate trees. In addition, the fact that LVDT sensors used in the experiment did not have to be repositioned, together with other operational advantages over discretely measured indicators, such as the low labour costs involved and the possibility of connection to remotely operated irrigation controllers, confirm that MDS is a suitable plant-based indicator for precise irrigation scheduling practices. Moreover, MDS exponential reference equations can be obtained by pooling data across several seasons for Tm. MDS first-order reference equations can be also obtained by pooling data across several seasons for ETo, VPDm, Tm and Rs. So, automated MDS measurements can be normalized to non-limiting water conditions by locally derived empirical relationships with meteorological variables. 


\title{
Assessment of discretely measured indicators and maximum daily trunk shrinkage for detecting water stress in pomegranate trees
}

\author{
A. Galindo ${ }^{a}$, P. Rodríguez ${ }^{b}$, C.D. Mellisho ${ }^{a}$, E. Torrecillas ${ }^{c}$, A. Moriana ${ }^{d}$, Z.N. Cruz ${ }^{b}$, \\ W. Conejero ${ }^{a}$, F. Moreno ${ }^{\mathrm{e}}$, A. Torrecillas ${ }^{\mathrm{a}, *}$ \\ ${ }^{a}$ Dpto. Riego. Centro de Edafología y Biología Aplicada del Segura (CSIC), P.O. Box 164, E-30100 Espinardo, Murcia, Spain \\ ${ }^{b}$ Dpto. Fisiología y Bioquímica, Instituto Nacional de Ciencias Agrícolas (INCA). Ctra. de Tapaste, km 3.5, San José de Las Lajas, Mayabeque, Cuba \\ cDpto. Conservación de Suelos y Agua, Centro de Edafología y Biología Aplicada del Segura (CSIC), P.O. Box 164, E-30100 Espinardo, Murcia, Spain

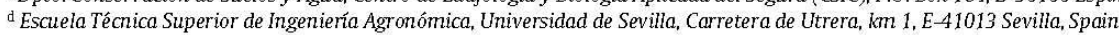 \\ ${ }^{2}$ Instituto de Recursos Naturales y Agrobiología (CSIC), P.O. Box 1052, E-41080 Sevilla, Spain
}

\section{A R T I C L E I N F O}

\section{Article history:}

Received 29 October 2012

Received in revised form 9 May 2013

Accepted 13 May 2013

\section{Keywords:}

Plant water relations

Punica granatum

Trunk diameter fluctuations

Water stress

\begin{abstract}
A B S T R A C T
Measurements obtained by the continuous monitoring of trunk diameter fluctuations were compared with discrete measurements of midday stem water potential $\left(\Psi_{\text {stem }}\right)$ and midday leaf conductance $\left(g_{1}\right)$ in adult pomegranate trees (Punica granatum L. cv. Mollar de Elche). Control plants (T0) were irrigated daily above their crop water requirements in order to attain non-limiting soil water conditions in 2009 and 2010, while T1 plants were subjected to water stress by depriving them of irrigation water for 34 days in 2010, after which time irrigation was restored and plant recovery was studied for 7 days. T1 plants showed a substantial degree of water stress, which developed slowly. Maximum daily trunk shrinkage (MDS) was identified to be the most suitable plant-based indicator for irrigation scheduling in adult pomegranate trees, because its signal:noise ((T1/T0):coefficient of variation) ratio was higher than that for $\Psi_{\text {stem }}$ ((T1/T0):coefficient of variation) and $g_{1}$ ((T0/T1):coefficient of variation). MDS increased in response to water stress, but when the $\Psi_{\text {stem }}$ fell below $-1.67 \mathrm{MPa}$, the MDS values decreased. For non-limiting water conditions, MDS could be predicted from mean daily air temperature $\left(T_{\mathrm{m}}\right)$ through exponential equations fitted to pooled data across several seasons. First-order equations were also obtained by pooling data across several seasons to predict MDS from crop reference evapotranspiration (ETo), mean daily air vapour pressure deficit $\left(\operatorname{VPD}_{\mathrm{m}}\right), T_{\mathrm{m}}$ and solar radiation $\left(R_{\mathrm{s}}\right)$, but these should be used only within a certain range of values (ETo, $2.1-7.4 \mathrm{~mm} ; \mathrm{VPD}_{\mathrm{m}}, 0.64-2.96 \mathrm{kPa} ; T_{\mathrm{m}}, 12.1-28.3^{\circ} \mathrm{C} ; R_{\mathrm{s}}$, 119.4-331.3 $\mathrm{Wm}^{-2}$ ). Hence, automated MDS measurements have the potential to be used in irrigation scheduling of pomegranate, and these values can be normalized to non-limiting water conditions by locally derived empirical relationships with meteorological variables.
\end{abstract}

(C) 2013 Elsevier B.V. All rights reserved.

\section{Introduction}

Pomegranate (Punica granatum L.) is one of the oldest known edible fruits, being among the seven kinds of fruit mentioned in the Bible (Blumenfeld et al., 2000). However, despite being grown commercially in many regions of the world, including countries of the Mediterranean Basin (Stover and Mercure, 2007; Holland et al., 2009), it has frequently been considered a minor crop. This is beginning to change and there is a growing interest in the consumption of pomegranate for their organoleptic characteristics and their perceived health benefits (Sumner et al., 2005; Lansky and Newman, 2007). Moreover, pomegranate is a very interesting fruit

\footnotetext{
* Corresponding author. Tel.: +34968 396330; fax: +34 968396213.

E-mail address: atorreci@cebas.csic.es (A. Torrecillas).
}

tree species because it has drought tolerance characteristics common in xeromorphic plants, such as high relative leaf apoplastic water content, and it is able to confront water stress by developing complementary stress avoidance and stress tolerance mechanisms (Rodríguez et al., 2012). For these reasons, this drought-hardy crop thrives well in arid and semiarid areas, even under desert conditions (Sarkhosh et al., 2006). However, to reach optimal growth, yield and fruit quality in arid and semiarid conditions, pomegranate trees require regular irrigation, particularly during the dry season (Holland et al., 2009; Prasad et al., 2003; Shaliendra and Narendra, 2005; Sulochanamma et al., 2005).

Frequent situations of imbalance between water supply and demand occur in Mediterranean agrosystems, which are facing increasing pressure to reduce water use. Indeed, there is a constant need to improve water use efficiency, and among the tools that growers can use to achieve this goal are more precise irrigation 
scheduling procedures that will protect water resources and their integrity for their future use (Naor and Cohen, 2003; Katerji et al. 2008).

Bhantana and Lazarovitch (2010) measured the evapotranspiration (ET), crop coefficients $\left(K_{\mathrm{c}}\right)$ and growth in two young pomegranate tree cultivars grown in lysimeters to varying electrical conductivity of the irrigation water. Their results indicated that salinity had a significant effect on both daily ET and total ET and that the calculated value of $K_{\mathrm{c}}$ is applicable for irrigation scheduling in young pomegranate orchards using irrigation water with various salinities. Intrigliolo et al. (2011a) suggested tentative preliminary irrigation recommendations for pomegranate trees. However, to the best of our knowledge, no specific studies have been conducted on irrigation scheduling in adult pomegranate plants under field conditions.

The use of plant-based water status indicators has become very popular for planning precise irrigation, because plant water status may be the ideal method for predicting crop performance under a given irrigation scheduling regime. Since plant water status controls many physiological processes and crop productivity, this information can be highly useful in irrigation scheduling (Fernández and Cuevas, 2010; Ortuño et al., 2010). Measurement of trunk diameter fluctuations (TDF) using LVDT (linear variable differential transducer) sensors provide continuous and automated recording of maximum daily trunk shrinkage (MDS), which has been shown to be suitable for the development of automated irrigation scheduling in fruit trees (Conejero et al., 2007; Ortuño et al., 2009a; Moriana et al., 2010).

Because plants are in the middle of the soil-plant-atmosphere continuum, plant water status is the result of soil water availability and evaporative demand. Therefore, absolute water stress indicator values recorded without considering the evaporative demand might be meaningless. For this reason, it is better to use the concept of signal intensity (SI) for irrigation scheduling, normalizing an indicator's absolute values with respect to values under nonlimiting soil water conditions (Naor and Cohen, 2003; Goldhamer and Fereres, 2001; Ortuño et al., 2005,2006). The SI for water stress indicators is a dimensionless variable, where values above unity indicate water stress levels, while SI values of unity indicate the absence of irrigation-related stress (Goldhamer and Fereres, 2004) Under operational irrigation scheduling, plant water status indicators for non-limiting conditions, needed for SI calculation, could be derived from previously established relationships with meteorological variables.

Intrigliolo et al. (2011b) suggested (i) differences in pomegranate water status could be detected earlier for mid day stem water potential ( $\left.\Psi_{\text {stem }}\right)$ than for MDS, (ii) a significant, but relatively low, correlation between MDS and crop reference evapotranspiration (ETo) $($ MDS $(\mu \mathrm{m})=23.0$ ETo $(\mathrm{mm})+8.8$ $\left.r^{2}=0.44^{* * * *}\right)$, whereas the relationships between MDS and air temperature and air vapour pressure deficit were even weaker, and iii) the best fit between MDS and $\psi_{\text {stem }}$ was obtained with a linear regression, which changed with fruit growth pattern or fruit removal. This behaviour was different from that of other fruit trees. For example, (i) MDS has been frequently found more sensitive than the other indicators in detecting plant water stress (Ortuño et al., 2010), (ii) some authors have shown that it is possible to predict adequately MDS reference values in crop trees with daily meteorological variables (Moreno et al., 2006; Ortuño et al., 2009b; Conejero et al., 2011), and (iii) Ortuño et al. (2010 indicated that in several fruit tree species under drought stress the decrease in $\psi_{\text {stem }}$ is associated with an increase in MDS, but this pattern changes at values below a $\Psi_{\text {stem }}$ threshold and any further reduction in $\psi_{\text {stem }}$ is associated with a decrease in MDS values.

The research presented here tested the hypothesis that the pomegranate MDS in response to changes in plant water status or meteorological variables can be predicted. In this study, the sensitivity of MDS in comparison with other discretely measured indicators of plant water status in response to a cycle of water deprivation and recovery was studied. In addition, the feasibility of obtaining reference equations for tree water status indicators in trees under non-limiting water conditions and their intra and inter-seasonal constancy was also investigated.

\section{Materials and methods}

\subsection{Plant material, experimental conditions and treatments}

Two different but complementary experiments were performed. The goal of the first experiment (2009) was to compare the sensitivity of MDS and discretely measured indicators of pomegranate tree water status in response to a cycle of water deprivation and recovery. The intra-season constancy of the relationships between MDS and meteorological variables was also investigated. The second experiment (2010) was performed to study the inter-season constancy of the obtained MDSrelationships under non-limiting soil water conditions.

\subsection{Experiment 1(2009)}

The experiment was carried out in 2009 on a farm located near the city of Murcia (Spain) $\left(37^{\circ} 57^{\prime} \mathrm{N}, 0^{\circ} 56^{\prime} \mathrm{W}\right)$. The plant material consisted of 264 own rooted 10-year old pomegranate trees (Punica granatum L.) cv. Mollar de Elche, with an average trunk diameter of about $15 \mathrm{~cm}$. Tree spacing followed a $3 \mathrm{~m} \times 6 \mathrm{~m}$ pattern, with an average ground cover of about $59 \%$. The design of the experiment was completely randomized with four replications, each replication consisted of three adjacent tree rows, each with eleven trees. Measurements were taken on the inner tree of the central row of each replicate, which were very similar in appearance (leaf area, trunk cross sectional area, height, ground shaded area, etc.), while the other trees served as border trees.

The soil of the orchard was a weakly saline $\left(2.1 \mathrm{dS} \mathrm{m}^{-1}\right)$ Xeric Torriorthent, with silt loam texture, high lime content ( $46 \%$ calcium carbonate), very low organic matter content ( $0.92 \%)$, low cationic exchange capacity ( 7.93 mequiv $100 \mathrm{~g}^{-1}$ ), and low available potassium and phosphorus levels. The irrigation water had an electrical conductivity of between 1.7 and $2.2 \mathrm{dS} \mathrm{m}^{-1}$ and the $\mathrm{Cl}^{-}$concentration in the irrigation water ranged from 36 to $48 \mathrm{mgl}^{-1}$.

Control plants (treatment T0) were irrigated above crop water requirements (115\% ETo), using six emitters (each delivering $41 \mathrm{~h}^{-1}$ ) per plant. Irrigation in T1 plants was withheld for 34 days (from day of the year (DOY) 209 to 243, second half of rapid fruit growth period). The recovery of plants was ensured by re-irrigation at the levels used in T0 for 6 days (from DOY 244 to 250). Total water amounts applied in the experimental period were 261 and $38 \mathrm{~mm}$ for $\mathrm{T} 0$ and $\mathrm{T} 1$ treatments, respectively.

\subsection{Experiment 2(2010)}

The experiment was performed in 2010 on another farm also located near the city of Murcia(Spain) $\left(37^{\circ} 47^{\prime} \mathrm{N}, 1^{\circ} 25^{\prime} \mathrm{W}\right)$. The plant material ( 156 trees) and tree spacing were similar to those used in experiment 1 . Trees showed an average trunk diameter of about $17 \mathrm{~cm}$ and an average ground cover of about $68 \%$. The experimental design was similar to that described for experiment 1 (2009) but using for each replication three adjacent tree rows, each with thirteen trees.

The soil of the orchard was a Hyposalic Calciorthid moderately saline $\left(5.9 \mathrm{dSm}^{-1}\right)$, with a silt loam texture, moderate lime content ( $20 \%$ calcium carbonate), very low organic matter content $(1.1 \%)$, low cationic exchange capacity (9.32 mequiv $100 \mathrm{~g}^{-1}$ ), 


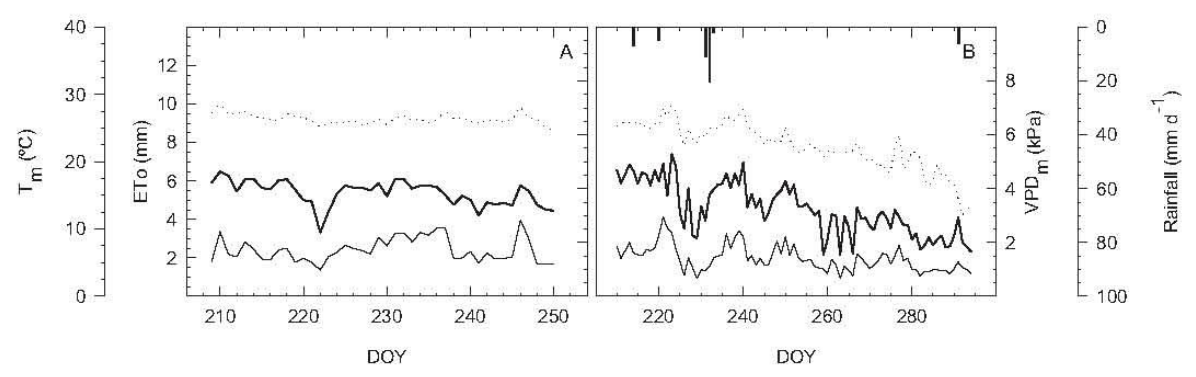

Fig. 1. Daily crop reference evapotranspiration (ETo, solid thick line), daily mean air temperature $\left(T_{\mathrm{m}}\right.$, dotted line), mean daily air vapour pressure deficit (VPD $\mathrm{m}_{\mathrm{m}}$, solid thin line) and daily rainfall (vertical bars) during the 2009 (A) and 2010 (B) experimental periods.

low available potassium and high available phosphorus levels. The irrigation water used had an electrical conductivity of between 0.8 and $1.0 \mathrm{dS} \mathrm{m}^{-1}$. The $\mathrm{Cl}^{-}$concentration in the irrigation water ranged from 62 to $70 \mathrm{mg}^{-1}$ during the experimental period.

Only over irrigated plants (T0) were considered to study the inter-seasonal constancy of the MDS reference equations (2009 vs. 2010). The experimental period was from DOY 210 to 294, that is from the beginning of the second half of rapid fruit growth period to the beginning of leaf fall. In order to guarantee non-limiting soil water conditions, control plants (treatment $\mathrm{T} 0$ ) were irrigated above crop water requirements ( $107 \%$ ETo), using three emitters (each delivering $41 \mathrm{~h}^{-1}$ ) per plant. Total water amount applied during the experimental period to $\mathrm{T} 0$ plants was $414 \mathrm{~mm}$.

During both experiments pest control and fertilization practices were those usually used by local growers, and no weeds were allowed to develop within the orchard. Irrigation was carried out daily and during the night using a drip irrigation system with one lateral pipe per tree row.

\subsection{Measurements}

Meteorological data, namely air temperature, solar radiation, air relative humidity, rainfall and wind speed $2 \mathrm{~m}$ above the soil surface, were collected every 15 min by automatic weather stations located near the experimental sites. Mean daily air vapour pressure deficit $\left(V_{P D}\right)$ and daily crop reference evapotranspiration (ETo) were calculated according to Allen et al. (1998).

Midday ( $12 \mathrm{~h}$ solar time) stem water potential $\left(\Psi_{\text {stem }}\right)$ was measured on the south facing side and the middle third of the trees, in two fully developed leaves per tree of each replicate, enclosing leaves in small black plastic bags covered with aluminium foil for at least $2 \mathrm{~h}$ before measurements in the pressure chamber (model 3005; Soil Moisture Equipment Co., Santa Barbara, CA, USA).

Midday leaf conductance $\left(g_{1}\right)$ in attached leaves was measured with a steady-state porometer (LI-1600; LICOR Inc., Lincoln, USA) on the abaxial surface of the leaves and in a similar number and type of leaves as used for the $\Psi_{\text {stem }}$ measurements.

The micrometric trunk diameter fluctuations (TDF) were measured throughout the experimental periods in four trees per treatment, using a set of linear variable displacement transducers (LVDT) (model DF $\pm 2.5 \mathrm{~mm}$, accuracy $\pm 10 \mu \mathrm{m}$, Solartron Metrology, Bognor Regis, UK) attached to the trunk, with a special bracket made of invar, an alloy of $\mathrm{Ni}$ and Fe with a thermal expansion coefficient close to zero (Katerji et al., 1994), and aluminium. Sensors were placed on the north side and were covered with silver thermoprotected foil to prevent heating and wetting of the device. Measurements were taken every $2 \mathrm{~s}$ and the datalogger (model CR10X with AM25T multiplexer, Campbell Scientific, Logan, UT) was programmed to report 15 min means. Maximum daily trunk shrinkage (MDS) was calculated as the difference between the daily maximum diameter (reached early in the morning) and the minimum diameter (usually reached in the afternoon).

All the above mentioned plant-based indicators were measured in both experiments, except $g_{1}$, which was measured only in experiment 1 (2009) to compare the sensitivity of MDS and discretely measured indicators to water deficit.

It is important to take into account that the absolute values of the plant water status indicators are influenced not only by soil water availability but also by the evaporative demand. So, to compare the sensitivity of the above mentioned plant-based indicators for use as water stress indicators it is more suitable to compare their values relative to those of the control trees (Naor and Cohen, 2003). For this, the signal intensity of both continuous and discrete plant water status measurements was defined as the relative values (T1/T0 (MDS and $\Psi_{\text {stem }}$ ) or T0/T1 $\left(g_{1}\right)$ ), while variability or noise was defined as the coefficient of variation of the mean. Thus, the signal:noise ratio integrates both the indicator strength and its variability, and is important for assessing the usefulness of plant-based water stress indicators for irrigation scheduling (Moreno et al., 2006; Goldhamer et al., 2000; Ortuño et al., 2004).

\subsection{Statistical analysis}

Data were analyzed using SPSS software (SPSS Inc., 2002). Analysis of variance was performed and means values were compared by an $\mathrm{LSD}_{0.05}$ test. Values for each replicate were averaged before the mean and the standard error of each treatment were calculated. Linear and exponential regression analyses were carried out to explore relationships between variables. Comparison between linear or log transformed exponential regression equations were performed using covariance analysis.

\section{Results}

During the 2009 and 2010 experimental periods, average daily maximum and minimum air temperatures were 32.5 and $20.2^{\circ} \mathrm{C}$ and 28.9 and $16.3^{\circ} \mathrm{C}$, respectively (Fig. 1). Mean daily air vapour pressure deficit $\left(\mathrm{VPD}_{\mathrm{m}}\right)$ ranged from 0.98 to $2.84 \mathrm{kPa}$ in 2009 and from 0.67 to $2.96 \mathrm{kPa}$ in 2010 (Fig. 1), and accumulated ETo was 226 and $387 \mathrm{~mm}$ in 2009 and 2010, respectively (Fig. 1). There was no rainfall during the 2009 experimental period, but in the 2010 experimental period total rainfall was $51 \mathrm{~mm}$, which took place mainly on DOY 214 (7 mm), 232 (20 mm) and 291 (6 mm) (Fig. 1).

$\Psi_{\text {stem }}$ values in control (T0) plants were high and quite constant, ranging between -0.73 and $-0.98 \mathrm{MPa}$ and between -0.76 and -0.92 MPa during the 2009 and 2010, respectively (Figs. 2A and 3A). During the 2009 water withholding period, $\Psi_{\text {stem }}$ values in T1 plants gradually declined, the decrease started to be significant from DOY 212 onwards and minimum values were reached at the end of the stress period. When plants were rewatered, $\Psi_{\text {stem }}$ values 

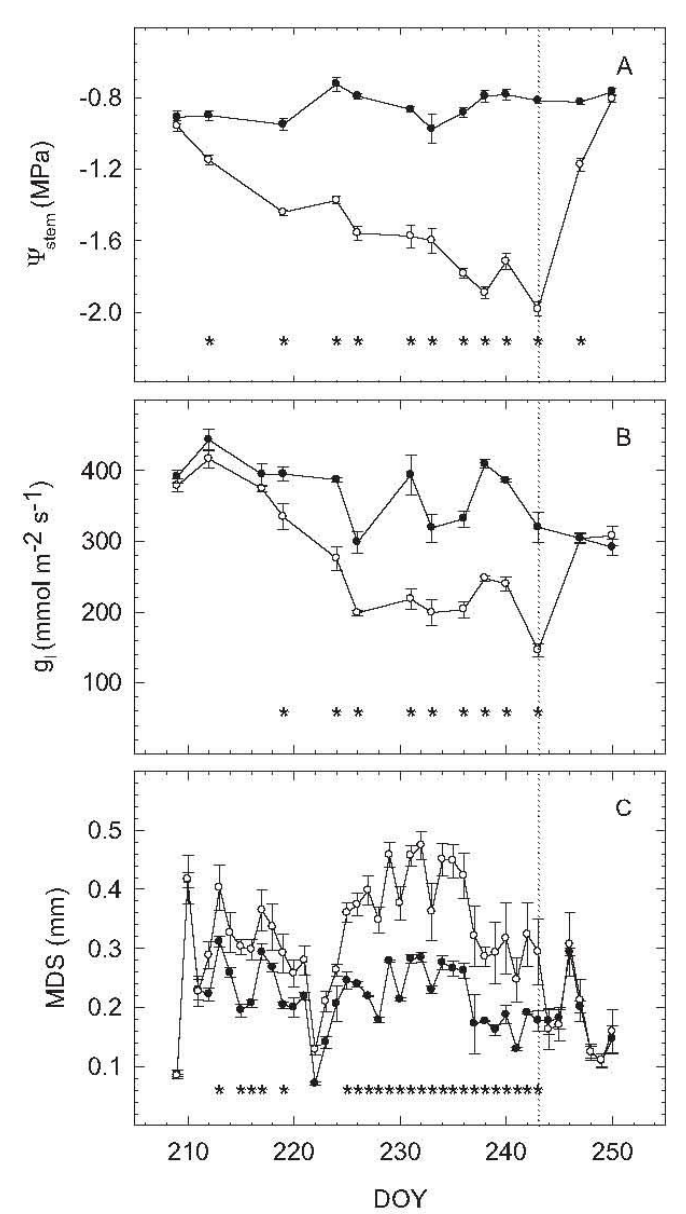

Fig. 2. Midday stem water potential $\left(\Psi_{\text {stemn }}\right)\left(\right.$ A), midday leaf conductance $\left(g_{1}\right)(B)$ and maximum daily trunk shrinkage (MDS) (C) in T0 (closed symbols) and T1 (open symbols) plants during the 2009 experimental period. Bars on data points are \pm S.E. of the mean (not shown when smaller than symbols). Vertical dotted line indicated the time at which irrigation was restored. Asterisks indicate statistically significant differences by least significant difference at $5 \%$ level $\left(\mathrm{LSD}_{0.05}\right)$ range test. Each point is the mean of four values.

gradually increased, reaching similar values to that observed for T0 plants at the end of the measurement period (Fig. 2A).

The $g_{1}$ in T0 plants were high and showed fluctuations, especially during the 2009 experimental period (Figs. 2B and 3A). In T1 plants, water deficit caused a gradual decrease in $g_{1}$, the reduction started to be significant after 10 days and minimum values were reached at the end of the stress period, before recovering when irrigation was initiated (Fig. 2B).

MDS values showed substantial fluctuations during the 2009 experimental period both in T0 and T1 plants (Fig. 2C). Differences between $\mathrm{T} 0$ and $\mathrm{T} 1$ treatments were evident as early as 4 days after the imposition of water stress, due to the MDS increase in T1 plants (Fig. 2C). When T1 plants were rewatered, MDS values fell and were similar in both treatments during the recovery period. MDS values in T0 plants during the 2010 experimental period fluctuated sharply before DOY 280, although from this day onwards, when evaporative demand decreased (Fig. 1B), MDS values were low and quite constant (Fig. 3B).

Taking into consideration the $\Psi_{\text {stem }}$ values obtained during the 2009 experimental period and the MDS values taken at the same

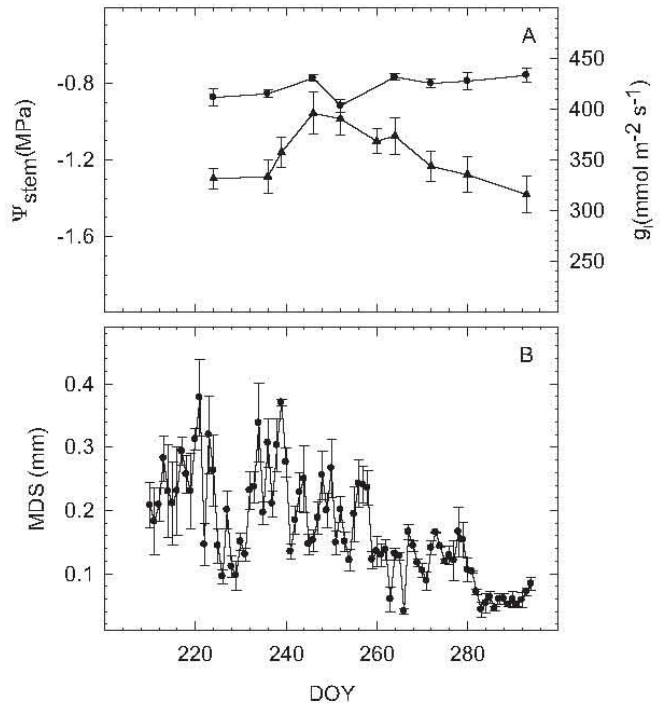

Fig. 3. Midday stem water potential ( $\Psi_{\text {stem }}$, circles) (A), midday leaf conductance Fig. 3. Midday stem water potential ( $\Psi_{\text {stem, }}$, circles) (A), midday leaf conductance (g), triangles) (A) and maximum daily trunk shrinkage (MDS) (B) in T0 plants during
the 2010 experimental period. Bars on data points are \pm S.E. of the mean (not shown when smaller than symbols). Each point is the mean of four values.

times, a polynomial relationship between both parameters (MDS $(\mathrm{mm})=0.419+0.979 \Psi_{\text {stem }}(\mathrm{MPa})+1.118 \Psi_{\text {stem }^{2}}(\mathrm{MPa})+0.331 \Psi_{\text {stem }}$ $\left.{ }^{3}(\mathrm{MPa}), r^{2}=0.685, \mathrm{MSE}=0.003\right)$ was evident in the range of water stress studied ( $\Psi_{\text {stem }}$ values from -0.72 to $-1.98 \mathrm{MPa}$ ) (Fig. 4). This relationship was characterized by two different phases. Above $\Psi_{\text {stem }}$ values of $-1.67 \mathrm{MPa}$, MDS values increased sharply as $\Psi_{\text {stem }}$ decreased, and when $\psi_{\text {stem }}$ values were below this threshold value the relationship changed and any further reduction in $\Psi_{\text {stem }}$ was associated with a decrease in MDS. Alternatively, despite the larger scatter, linear regression $\left(\mathrm{MDS}(\mathrm{mm})=0.056-0.168 \Psi_{\text {stem }}(\mathrm{MPa})\right.$, $r^{2}=0.587$, MSE $=0.004$ ) may be sufficient for modelling the relationship between $\Psi_{\text {stem }}$ and MDS in the water stress range studied (Fig. 4).

For precise irrigation scheduling based on changes in the plant water status, it is necessary to use plant-based water stress indicators able to develop an immediate, consistent and reliable response to water deficit. As a consequence, to compare the sensitivity of the measured indicators we looked at MDS as a continuously

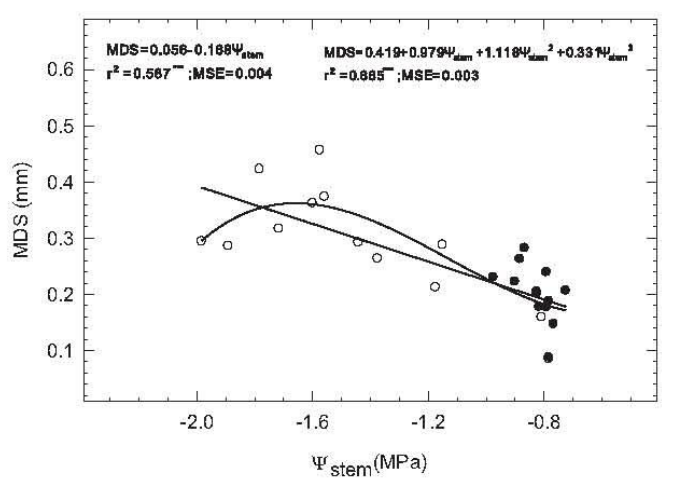

Fig. 4. Relationship between and maximum daily trunk shrinkage (MDS) and stem water potential ( $\Psi_{\text {stem }}$ ) in T0 (closed symbols) and T1 (open symbols) plants during the 2009 water stress period. Each value is the mean of four measurements. 


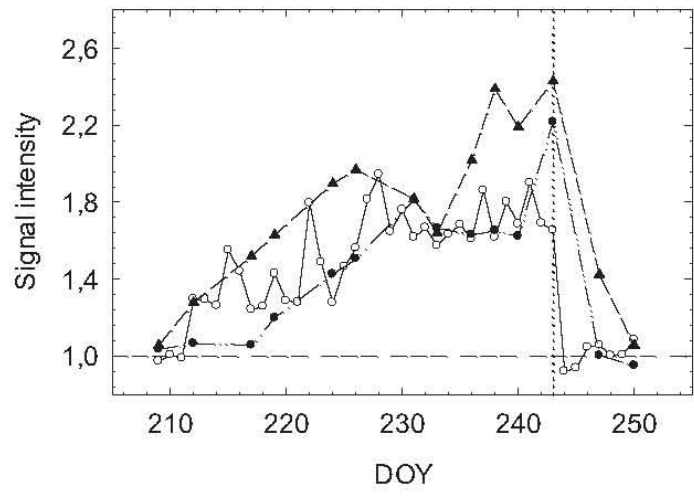

Fig. 5. Maximum daily trunk diameter shrinkage (MDS, open circles), midday stem water potential ( $\Psi_{\text {stem }}$, triangles) and midday leaf conductance ( $g_{1}$, closed circles) signal intensities during the 2009 experimental period. Each value is the mean of four measurements. Vertical dotted line indicated the time at which irrigation was restored.

recorded plant-based indicator and at $\psi_{\text {stem }}$ and $g_{1}$ as discretely measured plant-based indicators. In response to water stress the SI values in the three plant-based water stress indicators considered increased, with the particular characteristic that, at the beginning of the stress period, the MDS and $\Psi_{\text {stem }}$ SI (T1/T0) increased earlier than $g_{1} \mathrm{SI}$ (T0/T1), while MDS SI values during the water stress period showed more pronounced oscillations than the other indicators (Fig. 5). Moreover, when irrigation was restored, the SI values sharply decreased, minimum values of around unity occurring during the last days of the experiment (Fig. 5).

In a complementary manner, we studied the signal intensity, noise, and signal:noise ratio for MDS, $\Psi_{\text {stem }}$ and $g_{1}$ during increasing intervals of time from the beginning to the end of the stress period (Table 1). The data indicated that at the beginning of the water stress period MDS, $\Psi_{\text {stem }}$ and $g_{1}$ (DOY 209-217) presented similar mean SI and mean noise values. However, as the interval of time considered grew (DOY 209-238 and DOY 209-243), the $\Psi_{\text {stem SI }}$ was significantly higher than those for MDS and $g_{1}$, while $\Psi_{\text {stem }}$ and $g_{1}$ average noise values showed a tendency to be similar and higher than those observed in MDS, leading to the fact that the MDS

Table 1

Mean signal intensity (actual value/reference value or reference value/actual value) mean noise (coefficient of variation), and signal:noise ratio of maximum daily trunk shrinkage(MDS), midday stem water potential $\left(\Psi_{\text {stem }}\right)$ and midday leaf conductance (gi) at different intervals of the 2009 water stress period. For each interval, mean signal or mean noise values that do not have a common letter are significantly different according to the $\mathrm{LSD}_{0.05}$ range test.

\begin{tabular}{lllll}
\hline DOY & & Mean signal & Mean noise & Signal:noise \\
\hline \multirow{2}{*}{$209-217$} & MDS & $1.24 \mathrm{a}$ & $0.17 \mathrm{a}$ & 7.31 \\
& $\Psi_{\text {stem }}$ & $1.27 \mathrm{a}$ & $0.21 \mathrm{a}$ & 6.16 \\
& $\mathrm{~g}_{1}$ & $1.04 \mathrm{a}$ & $0.15 \mathrm{a}$ & 6.93 \\
$209-224$ & MDS & $1.31 \mathrm{ab}$ & $0.17 \mathrm{~b}$ & 7.84 \\
& $\Psi_{\text {stem }}$ & $1.46 \mathrm{a}$ & $0.23 \mathrm{a}$ & 6.27 \\
& $g_{1}$ & $1.15 \mathrm{~b}$ & $0.15 \mathrm{~b}$ & 7.73 \\
$209-231$ & MDS & $1.37 \mathrm{ab}$ & $0.17 \mathrm{~b}$ & 7.95 \\
& $\Psi_{\text {stem }}$ & $1.59 \mathrm{a}$ & $0.22 \mathrm{ab}$ & 7.13 \\
& $g_{1}$ & $1.29 \mathrm{~b}$ & $0.24 \mathrm{a}$ & 5.34 \\
$209-238$ & MDS & $1.41 \mathrm{~b}$ & $0.17 \mathrm{~b}$ & 8.24 \\
& $\Psi_{\text {stern }}$ & $1.72 \mathrm{a}$ & $0.23 \mathrm{a}$ & 7.39 \\
& $g_{1}$ & $1.40 \mathrm{~b}$ & $0.23 \mathrm{a}$ & 6.07 \\
$209-243$ & MDS & $1.46 \mathrm{~b}$ & $0.18 \mathrm{~b}$ & 8.31 \\
& $\Psi_{\text {stern }}$ & $1.81 \mathrm{a}$ & $0.24 \mathrm{a}$ & 7.63 \\
& $g_{1}$ & $1.49 \mathrm{~b}$ & $0.26 \mathrm{a}$ & 5.82 \\
\hline
\end{tabular}

Table 2

Intercept ( $a$ ), slope ( $b$ ), coefficient of determination $\left(r^{2}\right)$, number of data points ( $n$ ) and mean square error(MSE) of first-order linear equations $(y=a+b x)$ between max imum daily trunk shrinkage (MDS, mm) and selected environmental variables for 2009 and 2010 seasons.

\begin{tabular}{|c|c|c|c|c|c|}
\hline Season & $a$ & $b$ & $r^{2}$ & $n$ & MSE \\
\hline \multicolumn{6}{|c|}{ MDS vs. ETo (mm) } \\
\hline 2009 & -0.0841 & 0.0557 & $0.7519^{\cdots}$ & 49 & 0.0009 \\
\hline 2010 & -0.0680 & 0.0519 & $0.7482^{\ldots *}$ & 85 & 0.0017 \\
\hline \multicolumn{6}{|c|}{$M D S$ vs $V P D_{m}(k P a)$} \\
\hline 2009 & 0.0329 & 0.1001 & $0.598^{* *}$ & 49 & 0.0015 \\
\hline 2010 & -0.0249 & 0.1370 & $0.6152^{* *}$ & 85 & 0.0025 \\
\hline \multicolumn{6}{|c|}{$\operatorname{MDS} v s T_{m}\left({ }^{\circ} \mathrm{C}\right)$} \\
\hline 2009 & -0.2922 & 0.0192 & $0.4197^{\cdots *}$ & 49 & 0.0021 \\
\hline 2010 & -0.2363 & 0.0181 & $0.5933^{\ldots}$ & 85 & 0.0027 \\
\hline \multicolumn{6}{|c|}{$M D S$ vs $R_{s}\left(W m^{-2}\right)$} \\
\hline 2009 & -0.0615 & 0.001 & $0.665^{\ldots}$ & 49 & 0.0012 \\
\hline 2010 & -0.0739 & 0.001 & $0.6024^{\ldots+}$ & 85 & 0.0025 \\
\hline
\end{tabular}

ETo, daily crop reference evapotranspiration; $T_{\mathrm{m}}$, daily mean air temperature; $\mathrm{VPD}_{\mathrm{m}}$ daily mean air vapour pressure deficit; $R_{s}$, solar radiation.

-* Significant at $P<0.001$.

signal:noise ratio was the highest ratio for all the intervals of time considered (Table 1).

During the 2009 and 2010 experimental periods, the observations of MDS in trees under non-limiting soil water conditions showed significant first-order and exponential correlations with meteorological variables measured on a whole-day basis (ETo, $\mathrm{VPD}_{\mathrm{m}}$, mean daily air temperature $\left(T_{\mathrm{m}}\right)$ and solar radiation $\left.\left(R_{\mathrm{s}}\right)\right)$ (Tables 2 and 3 ). These reference equations in pomegranate trees suggested that the best predictor for MDS reference values was ETo because the relations between both variables showed the highest coefficients of determination (Tables 2 and 3). Moreover, it is important to indicate that most equations in Table 2 predict a negative MDS value under low values of the meteorological variables studied and exponential regressions (Table 3 ) improved the goodness of fit of most first-order reference equations in Table 2.

The covariance analysis of the MDS first-order reference equations using $\mathrm{ETo}, \mathrm{VPD}_{\mathrm{m}}, T_{\mathrm{m}}$ and $R_{\mathrm{s}}$ as independent variables showed that differences in slopes and intercepts between both experimental seasons were not statistically significant. This suggests that it could be possible to evaluate MDS by means of a first-order fit and by pooling data across both experimental seasons (Fig. 6). However, the covariance analysis of the MDS exponential fit showed this was true only when $T_{\mathrm{m}}$ was used as independent variable (Fig. 7) across both experimental seasons.

Table 3

Parameters $(a, b)$, coefficient of determination $\left(r^{2}\right)$, number of data points $(n)$ and mean square error (MSE) of exponential equations $\left(y=a e^{b x}\right.$ ) between maximum daily trunk shrinkage (MDS, $\mathrm{mm}$ ) and selected environmental variables for 2009 and 2010 seasons.

\begin{tabular}{|c|c|c|c|c|c|}
\hline Season & $a$ & $b$ & $r^{2}$ & $n$ & MSE \\
\hline \multicolumn{6}{|c|}{ MDS vs.ETo (mm) } \\
\hline 2009 & 0.0343 & 0.3359 & $0.8054^{-*}$ & 49 & 0.0007 \\
\hline 2010 & 0.0299 & 0.3494 & 0.7424 & 85 & 0.0019 \\
\hline \multicolumn{6}{|c|}{$M D S$ vs $V P D_{m}(k P a)$} \\
\hline 2009 & 0.0731 & 0.5725 & $0.5767^{* * *}$ & 49 & 0.0017 \\
\hline 2010 & 0.0433 & 0.8660 & $0.5384^{* * *}$ & 85 & 0.0030 \\
\hline \multicolumn{6}{|c|}{$M D S$ vs $T_{m}\left({ }^{\circ} \mathrm{C}\right)$} \\
\hline 2009 & 0.0088 & 0.1200 & $0.4825^{\ldots+*}$ & 49 & 0.0020 \\
\hline 2010 & 0.0089 & 0.1253 & $0.6236^{* *}$ & 85 & 0.0024 \\
\hline \multicolumn{6}{|c|}{$M D S$ vs $R_{s}\left(W m^{-2}\right)$} \\
\hline 2009 & 0.0273 & 0.0072 & $0.6344^{-\ldots}$ & 49 & 0.0010 \\
\hline 2010 & 0.0292 & 0.0070 & $0.6620^{\cdots-}$ & 85 & 0.0025 \\
\hline
\end{tabular}

ETo, daily crop reference evapotranspiration; $T_{\mathrm{m}}$, daily mean air temperature, $\mathrm{VPD}_{\mathrm{m}}$. daily mean air vapour pressure deficit; $R_{S}$, solar radiation.

... Significant at $P<0.001$. 

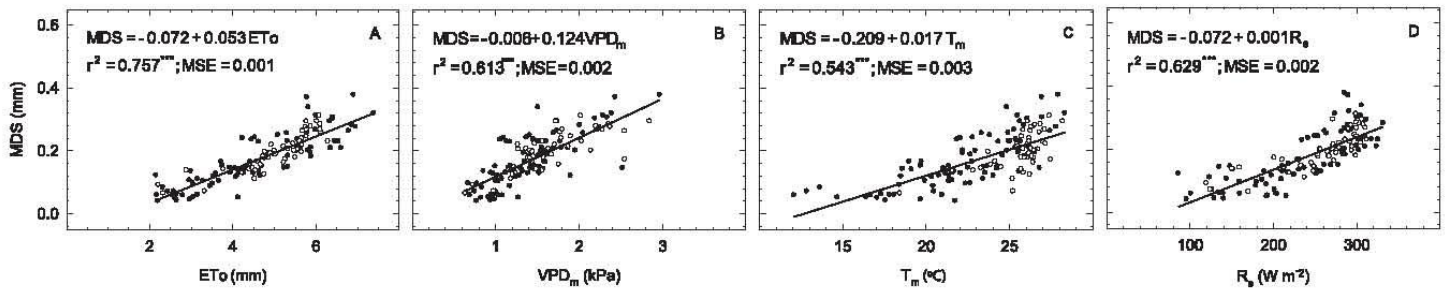

Fig. 6. Relationships for trees under non-limiting soil moisture conditions (T0) between maximum daily trunk shrinkage (MDS) and daily values of reference crop evapotranspiration (ETo) (A), mean daily air vapour pressure deficit $\left(\mathrm{VPD}_{\mathrm{m}}\right)(\mathrm{B})$, mean daily air temperature $\left(T_{\mathrm{m}}\right)(\mathrm{C})$ and solar radiation $\left(R_{\mathrm{s}}\right)(\mathrm{D})$, using all data pooled $(2009$, open circles; 2010, closed circles). Each data point is the mean of four values.

\section{Discussion}

The high $\Psi_{\text {stem }}$ and $g_{1}$ values in T0 plants throughout both experimental periods (Figs. 2A and 3A) suggested that control pomegranate plants were under non-limiting soil water conditions. $\Psi_{\text {stem }}$ values in T1 plants at the end of the water withholding period (Fig. 2A) and the stomatal regulation observed (Fig. 2B) pointed to a relatively strong water stress situation. However, the decrease in $\Psi_{\text {stem }}$ values at a rate of around $0.025 \mathrm{MPa} \mathrm{day}^{-1}$ indicates that the water stress developed quite slowly (Hale and Orcutt, 1987).

The fact that at the longest intervals of time during the water withholding period (DOY 209-238 and 209-243) $\Psi_{\text {stem }}$ and $g_{1}$ variability (mean noise) were higher than that showed by MDS (Table 1) agrees with the idea that plant water status indicators have higher variances under water deficit conditions due to the increase in the variability of soil moisture at the field scale (Russo et al., 1994 Naor et al., 1995; Stern et al., 1998). Moreover, according to Naor and Cohen (2003), the lower and near constant MDS mean noise values could be related to the fact that MDS is not a direct indicator of plant water status, because MDS is actually a length measure and its variability could be attributed to differences in size of the shrinking tissue and to differences of conductance of water between the bark and the xylem vessels.

The fact that MDS signal:noise ratio was higher than that for $\Psi_{\text {stem }}$ and $g_{1}$ for all the intervals of time considered (Table 1 ) suggested that MDS is the most suitable indicator for pomegranate irrigation scheduling. In this sense, Ortuño et al. (2004, 2006) showed that continuously measured plant water status indicators were more immediate and sensitive than discretely measured indicators. Moreover, Remorini and Massai (2003) indicated that trunk diameter fluctuations differed between irrigation treatments even

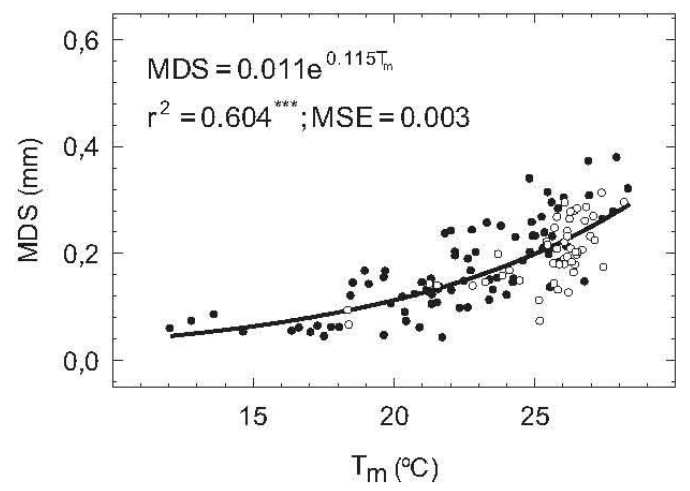

Fig. 7. Relationship for trees under non-limiting soil moisture conditions (T0) between maximum daily trunk shrinkage (MDS) and mean daily air temperature $\left(T_{m}\right)$ using all data pooled (2009, open circles; 2010 , closed circles). Each data point is the mean of four values. in the absence of differences in $\Psi_{\text {stem }}$, and Goldhamer et al. (1999) indicated that MDS responded sooner than $\Psi_{\text {stem }}$ to water stress.

The changes in trunk diameter are closely related to changes in water content in the whole plant (Simonneau et al., 1993). For this, several authors have observed that MDS values are a good indicator of transpiration intensity when the soil water content is not strongly depleted, and increases in MDS have been associated with decreases in water potential (Huguet et al., 1992; Herzog et al., 1995). In accordance with these ideas, our results indicated that the best fit between MDS and $\Psi_{\text {stem }}$ was obtained with a polynomial regression model (Fig. 4), which is the behaviour more frequent in most species and it is characterized by the existence of a $\Psi_{\text {stem }}$ threshold value $(-1.67 \mathrm{MPa})$ below which any further reduction in $\Psi_{\text {stem }}$ is associated with a decrease in MDS values (Ortuño et al., 2010; Moriana et al., 2000). However, Intrigliolo et al. (2011b), suggested that the best fit between MDS and $\Psi_{\text {stem }}$ in pomegranate trees was obtained with a linear regression, and that there was not a single unique relationship between both variables valid for the whole season due to changes in fruit growth pattern and fruit removal. In this sense, our data also revealed the possibility of presenting the relationship between MDS and $\Psi_{\text {stem }}$ by means of a first-order fit but the correlation obtained was worse than for the polynomial regression model (Fig. 4). In our opinion, to clarify the model that defines the relationship between both variables, a higher number of MDS data points corresponding to $\Psi_{\text {stem }}$ values below $-1.67 \mathrm{MPa}$ would have been necessary.

The significant relations between MDS and ETo, VPD $\mathrm{m}, T_{\mathrm{m}}$ and $R_{\mathrm{s}}$ in pomegranate trees growing under non-limiting soil water conditions (Tables 2 and 3 ) indicated that MDS, as well as reflecting tree water status, was clearly influenced by weather conditions (Fernández and Cuevas, 2010; Ortuño et al., 2009b, 2010; Conejero et al., 2011; Moriana et al., 2011). These individual reference equations between MDS and environmental variables have the potential to be used to obtain MDS reference values under non-limiting soil water conditions and normalize MDS actual values, avoiding the use of over irrigated reference trees.

Taking into consideration that MDS reflects the continuous trunk diameter records on a diurnal basis, being an integrative indicator could explain its relation with these climatic variables measured on a whole-day basis (Tables 2 and 3 ). In contrast with that reported by other authors (Fernández and Cuevas, 2010; Ortuño et al., 2010), the fact that most equations in Table 2 showed a negative intercept could suggest that pomegranate trees are different from other species in their response to meteorological variables. As a consequence, it would be well advised not to use MDS reference equations in Fig. 6 under low ETo, VPD,$T_{\mathrm{m}}$ and $R_{\mathrm{s}}$ values because these reference equations can predict negative MDS values, which does not make sense from a physical or physiological point of view. Nevertheless, MDS values could be predicted using reference equations in Fig. 6 only when these meteorological variables values were within the range of values used to determine these reference equations (ETo, 2.1-7.4 mm; $\mathrm{VPD}_{\mathrm{m}}, 0.64-2.96 \mathrm{kPa} ; T_{\mathrm{m}}, 12.1-28.3^{\circ} \mathrm{C} ; R_{\mathrm{s}}$, 
119.4-331.3 Wm ${ }^{-2}$ ). So, using these ETo, $\mathrm{VPD}_{\mathrm{m}}, T_{\mathrm{m}}$ and $R_{\mathrm{s}}$ boundary values negative MDS values are not predicted.

The tighter correlation for the first order equations of MDS versus ETo than those of MDS versus VPD $\mathrm{m}, R_{\mathrm{s}}$ and $T_{\mathrm{m}}$ (Tables 2 and 3 ), could be related to the fact that ETo calculation includes vapour pressure deficit, mean daily air temperature and solar net radiation values. However, it is difficult to explain why the behaviour of MDS under non-limiting soil water conditions can be adequately predicted by changes in $T_{\mathrm{m}}$ (Figs. 6 and 7) because it is known that temperature is not an accurate indicator of the evaporative demand of the atmosphere (Hatfield and Fuchs, 1990). Nevertheless, earlier reports in almond (Fereres and Goldhamer, 2003), plum (Intrigliolo and Castel, 2006) olive (Moreno et al., 2006; Tognetti et al., 2009; Cocozza et al., 2012) and lemon (Ortuño et al., 2009b) showed that air temperature is a good predictor of MDS. In any case, it must be considered that $T_{\mathrm{m}}$ is a climatic variable that is easier and less costly to measure than $\mathrm{ETo}, \mathrm{VPD}_{\mathrm{m}}$ and $R_{\mathrm{s}}$.

The main advantage of using MDS and $\psi_{\text {stem }}$ as a tool for precise irrigation scheduling is that the same signal intensity threshold values can be used in different orchards. In this sense, in spite of some differences in the location of experimental plots and tree size, the inter-seasonal constancy in the pomegranate reference equations to estimate MDS (Figs. 6 and 7) was in agreement with the results showed by other authors in lemon and peach trees (Ortuño et al., 2009b; Conejero et al., 2011). Nevertheless, it is important to indicate that before generalizing the use of MDS reference equations for an adult fruit tree, some key precautions should be taken into account. In this sense, the effects of environmental conditions on daily MDS values can be significantly dependent on crop load (Moriana and Fereres, 2004; Intrigliolo and Castel, 2007), even though other authors suggested that $\Psi_{\text {stem }}$ and MDS values are affected by crop load only when very different crop load levels are compared (Ortuño et al., 2009b; Conejero et al., 2010, 2011). For this, before MDS measurements can be used in irrigation scheduling, we recommend to study the effect of different cropload, within the range of the fruit alternate bearing pattern, on MDS values.

Overall, the results indicated that MDS is a reliable plant-based water stress indicator in adult pomegranate trees. In addition, the fact that LVDT sensors used in the experiment did not have to be repositioned, together with other operational advantages over discretely measured indicators, such as the low labour costs involved and the possibility of connection to remotely operated irrigation controllers, confirm that MDS is a suitable plant-based indicator for precise irrigation scheduling practices. Moreover, MDS exponential reference equations can be obtained by pooling data across several seasons for $T_{\mathrm{m}}$. MDS first-order reference equations can be also obtained by pooling data across several seasons for $\mathrm{ETo}, \mathrm{VPD}, T_{\mathrm{m}}$ and $R_{\mathrm{s}}$, but these reference equations should be used only within a certain range of values (ETo, 2.1-7.4 mm; $\left.\mathrm{VPD}_{\mathrm{m}}, 0.64-2.96 \mathrm{kPa} ; T_{\mathrm{m}}, 12.1-28.3^{\circ} \mathrm{C} ; R_{\mathrm{s}}, 119.4-331.3 \mathrm{Wm}^{-2}\right)$. So, automated MDS measurements can be normalized to non-limiting water conditions by locally derived empirical relationships with meteorological variables.

\section{Acknowledgements}

This research was supported by Ministerio de Ciencia e Innovación (MICINN) (CICYT/FEDER AGL2010-19201-C04-01AGR) and Agencia Española de Cooperaciốn Internacional para el Desarrollo (AECID) (A1/035430/11) grants to the authors.

\section{References}

Allen, R.G., Pereira, R.S., Raes, D., Smith, M., 1998. Crop evapotranspirationguidelines for computing crop water requirements. FAO Irrigation and Drainage Paper No. 56, Rome, Italy, pp. 15-27.
Bhantana, P., Lazarovitch, N., 2010. Evapotranspiration crop coefficient and growth of two young pomegranate (Punica granatum L.) varieties under salt stress. Agric. Water Manage. 97, 715-722.

Blumenfeld, A., Shaya, F., Hillel, R., 2000. Cultivation of pomegranate. In: Options Méditerranées. CIHEAM http://ressources.ciheam.org/om/pdf a42/00600264.pdf

Cocozza, C., Giovannelli, A., Lasserre, B., Cantini, C., Lombardi, F., Tognetti, R., 2012. A novel mathematical procedure to interpret the stem radius variation in olive trees. Agric. For. Meteorol. 161,80-93.

Conejero, W., Alarcón, J.J., García-Orellana, Y., Nicolás, E., Torrecillas, A., 2007. Evaluation of sap flow and trunk diameter sensors used for irrigation scheduling in early maturing peach trees. Tree Physiol. 27, 1753-1759

Conejero, W. Mellisho, C.D. Ortuño, M.F, Galindo, A., Pérez-Sarmiento, F., Torrecillas, A., 2011. Establishing maximum daily trunk shrinkage and midday stem water potential reference equations for irrigation scheduling of early maturing peach trees. Irrig. Sci. 29, 299-309

Conejero, W., Ortuño, M.F., Mellisho, C.D., Torrecillas, A., 2010. Influence of crop load on maximum daily trunk shrinkage reference equations for irrigation scheduling of early maturing peach trees. Agric. Water Manage. 97, 333-338.

Fereres, E., Goldhamer, D.A., 2003. Suitability of stem diameter variations and water potential as indicators for irrigation scheduling of almond trees. J. Hort. Sci. Biotech. 78, 139-144

Fernández,J.E., Cuevas, M.V., 2010. Irrigation scheduling from stem diameter variations: a review. Agric, For. Meteorol. 150, 135-151.

Goldhamer, D.A., Fereres, E., 2001. Irrigation scheduling protocols using continuously recorded trunk diameter measurements. Irrig. Sci. 20, 115-125.

Goldhamer, D.A., Fereres, E., 2004. Irrigation scheduling of almond trees with trunk diameter sensors. Irrig. Sci. 23, 11-19.
diamer, D.A., Ferere, E. 2004. Irrigation

Goldhamer, D.A., Fereres, E., Cohen, M., Girona, J., Mata, M., 2000. Comparis on of continuous and discrete plant-bas ed monitoring for detecting tree water deficits and barriers to grower adoption for irrigation management. Acta Hortic. 537 , $431-445$.

Goldhamer, D.A., Fereres, E., Mata, M., Girona, J., Cohen, M., 1999. Sensitivity of continuous and discrete plant and soil water status monitoring in peach trees subjected to deficit irrigation. J. Am. Soc. Hortic. Sci. 124, 437-444.

Hale, M.G., Orcutt, D.M., 1987. The Physiology of Plants Under Stress. Wiley, New York.

Hatfield, J.L, Fuchs, M.F., 1990. Evapotranspiration models. In: Hoffman, G.J., Howell, T.A., Solomon, K.H. (Eds.), Management of Farm Irrigation Systems. ASAE Monograph, St Joseph, pp. 33-60.

Herzog, K.M., Häsler, R., Thum, R., 1995. Diurnal changes in the radius of a subalpine Norway spruce stem: their relation to the sap flow and their use to estimate Norway spruce stem: their relation
transpiration. Trees 10, 94-101.

Holland, D., Hatib, K., Bar-Yàakov, I., 2009. Pomegranate: botany horticulture, breeding. Hortic. Rev. 35, 127-191.

Huguet, J.G., Li, S.H., Lorendeau, J.Y., Pelloux, G., 1992. Specific micromorphometric reactions of fruit trees to water stress and irrigation scheduling automation. J. Hort. Sci. 67,631-640.

Intrigliolo, D.S., Castel, J.R., 2006. Usefulness of diurnal trunk shrinkage as a water stress indicator in plum trees. Tree Physiol. 26, 303-311.

Intrigliolo, D.S., Castel, J.R., 2007. Crop load affects maximum daily trunk shrinkage of plum trees. Tree Physiol. 27,89-96.

Intrigliolo, D.S., Nicolás, E., Bonet, L., Ferrer, P., Alarcón, J.J., Bartual, J., 2011a. Water relations of field grown Pomegranate trees (Punica granatum) under different drip irrigation regimes. Agric. Water Manage. 98, 691-696.

Intrigliolo, D.S., Puerto, H., Bonet, L., Alarcón, J.J., Nicolás, E., Bartual, J., 2011b. Usefulness of trunk diameter variations as a continuous water stress indicaUsefulness of trunk diameter variations as a continuous water stress indica-
tors of pomegranate (Punica granatum) trees. Agric. Water Manage. 98, 1462tors of
1468 .

Katerji, N., Mastrorilli, M., Rana, G., 2008. Water use efficiency of crops cultivated in the Mediterranean region: review and analysis. Eur. J. Agron. 28, 493-507.

Katerji, N., Tardieu, F., Bethenod, O., Quetin, P., 1994. Behavior of maize stem diameter during drying cycles: comparison of two methods for detecting water stress. Crop Sci. 34, 65-169

Lansky, E.P., Newman, R.A., 2007. Review: Punica granatum (pomegranate) and its potential for prevention and treatment of inflammation and cancer. J. Ethnopharm. 109, 177-206.

Moreno, F., Conejero, W., Martín-Palomo, M.J., Girón, L.F., Torrecillas, A., 2006. Maximum daily trunk shrinkage reference values for irrigation scheduling in olive trees. Agric. Water Manage. 84, 290-294.

Moriana, A., Fereres, E., 2004. Establishing reference values of trunk diameter fluctuations and stem water potential for irrigation scheduling of olive trees. Acta Hortic. 664, 407-412.

Moriana, A., Fereres, E., Orgaz, F., Castro, J., Humanes, M.D., Pastor, M., 2000. The relations between trunk diameter fluctuations and tree water status in olive relations between trunk diameter fluctuations a.
trees (Olea europea L.). Acta Hortic. 537, 293-297.

Moriana, A., Girón, I.F., Martín-Palomo, M.J., Conejero, W., Ortuño, M.F., Torrecillas, A., Moreno, F., 2010. New approach for olive trees irrigation scheduling using trunk diameter sensors. Agric. Water Manage. 97, 1822-1828.

Moriana, A., Moreno, F., Girón, L.F., Conejero, W., Ortuño, M.F., Morales, D., Corell, M., Torrecillas, A., 2011. Seasonal changes of maximum daily shrinkage reference equations for irrigation scheduling in olive trees: influence of fruit load. Agric. Water Manage. 99,121-127.

Naor, A., Cohen, S., 2003. Sensitivity and variability of maximum trunk shrinkage midday stem water potential, and trans piration rate in response to with holding irrigation from field grown apple trees. HortSci. 38, 547-551. 
Naor, A., Klein, I., Doron, I., 1995. Stem water potential and apple fruit size. J. Am. Soc. Hort Sci. 120,577-582

Ortuño, M.F., Alarcón, J.J., Nicolás, E., Torrecillas, A., 2004. Comparison of continuously recorded plant-based waters tress indicators for young lemon trees. Plant Soil 267, 263-270.

Ortuño, M.F., Alarcón, J.J., Nicolás, E., Torrecillas, A., 2005. Sap flow and trunk diameter fluctuations of young lemon trees under water stress and rewatering. Environ. Exp. Bot. 54, 155-162.

Ortuño, M.F., Brito, J.J., Conejero, W., García-Orellana, Y., Torrecillas, A., 2009a. Using continuously recorded trunk diameter fluctuations for estimating water requirements of lemon trees. Irrig. Sci. 27, 271-276

Ortuño, M.F., Brito, J.J., García-Orellana, Y., Conejero, W., Torrecillas, A., 2009b. Maximum daily runk shrinkage and stem water potential reference equations for irrigation scheduling of lemon trees. Irrig. Sci. 27, 121-127.

Ortuño, M.F., Conejero, W., Moreno, F., Moriana, A., Intrigliolo, D.S., Biel, C., Mellisho, C.D., Pérez-Pastor, A., Domingo, R., Ruiz-Sánchez, M.C., Casadesus, J., Bonany, J., Torrecillas, A., 2010. Could trunk diameter sensors be used in woody crops for irrigation scheduling? A review of current knowledge and future perspectives. irrigation scheduling? A review
Agric. Water Manage. 97, 1-11.

Ortuño, M.F., García-Orellana, Y., Conejero, W., Ruiz-Sánchez, M.C., Alarcón, J.J., Torrecillas, A., 2006. Stem and leaf water potentials, gas exchange, sap flow and recillas, A., 2006. Stem and leaf water potentials, gas exchange, sap flow and trunk $1-8$.

Prasad, R.N., Bankar, G.J., Vashishtha, B.B., 2003. Effect of drip irrigation on growth yield and quality of pomegranate in arid region. Indian J. Hortic. 60, 140-142.

Remorini,D., Massai, R., 2003. Comparison of water status indicators for young peach trees. Irrig. Sci. 22, 39-46.

Rodríguez, P., Mellisho, C.D., Conejero, W., Cruz, Z.N., Ortuño, M.F., Galindo, A., Torrecillas, A., 2012. Plant water relations of leaves of pomegranate trees under different irrigation conditions. Environ. Exp. Bot. 77, 19-24.
Russo,D.,Zaidel,J., Laufer, A., 1994. Stochastic analysis of solute trans port in partially saturated heterogeneous soil. I. Numerical experiments. Water Resour. Res. 30 $769-779$

Sarkhosh, A., Zamani, Z., Fatahi, R., Ebadi, A., 2006. RAPD markers reveal polymorphism among some Iranian pomegranate (Punica granatum L) genotypes. Sci Hort. $111,24-29$.

Shaliendra, A., Narendra,A., 2005. The effect of trickle irrigation on growthyield and quality of pomegranate (Punica granatum) cv. Ganesh in Chhattisgarh region Mysore J. Agric. Sci. 39, 175-181.

Simonneau, T., Habib, R., Goutouly, J.P., Huguet, J.G., 1993. Diurnal changes in stem diameter depend upon variations in water content: direct evidence in peach trees. J. Exp. Bot. 44,615-621.

SPSS Inc., 2002. SPSS Professional Statistics. Business Intelligence Division, v.12. SPSS Inc, Chicago.

Stern, R., Meron, M., Naor, A., Gazit, S., Bravdo, B., Wallach, R., 1998. Effect of autumnal irrigation level in 'Mauritius' lychee on soil and plant water status and following year flowering intensity and yield. J. Am. Soc. Hort. Sci. 123, 150-155.

Stover, E., Mercure,E.W., 2007. The pomegranate: a new look at the fruit of paradise. HortSci. 42, 1088-1092.
Her,

Sulochanamma, B.N., Yellamanda Reddy, T., Subbi Reddy, G., 2005. Effect of basin and drip irrigation on growth yield and water use efficiency in pomegranate $\mathrm{cv}$. Gennesh. Acta Hortic. 696, 277-279.

Sumner, M.D., Elliott-Eller, M., Weidner, G., Daubenmier, J.J., Chew, M.H., Marlin, R., Raisin, C.J., Ornish, D., 2005. Effect of pomegranate juice consumption on mycocardial perfusion in patient with coronary heart disease. Am. J. Cardiol. 96 810-814.

Tognetti, R., Giovannelli, A., Lavini, A., Morelli, G., Fragnito, F., d’Andria, R. 2009. Assessing environmental controls over conductances through the soil-plant-atmosphere continuum in an experimental olive tree plantation of southern Italy. Agric. For. Meteorol. 149, 1229-1243. 
Agricultural Water Management 114(2012) 30-36

Contents lists available at SciVerse ScienceDirect

Agricultural Water Management

Pomegranate (Punica granatum L.) fruit response to different deficit irrigation conditions

C.D. Mellisho ${ }^{a}$, I. Egea $^{\mathrm{a}}$, A. Galindo ${ }^{\mathrm{a}}$, P. Rodríguez ${ }^{\mathrm{b}}$, J. Rodríguez $^{\mathrm{b}}$, W. Conejero ${ }^{\mathrm{a}}$, F. Romojaro ${ }^{\mathrm{a}}$, A. Torrecillas ${ }^{a, c,+}$

\section{Methods}

See pages 77 and 78 .

\section{Results}

The decrease in plants under moderate water stress (T1) total marketable yield was due to the lower yield, fruit size and average fruit weight at the second harvest, since, at the first harvest, when only fruits of marketable size and colour were harvested, control plants (T0) and T1 plants presented similar yield and fruit characteristics. The decrease in plants under severe water stress (T2) total yield was due to the presence of fruits showing the lowest size and average weight at both harvests. Peel $L^{*}$ values increased from the first to the second harvest, while $H^{\circ}$ decreased. No significant effect of the irrigation treatment on pomegranate peel or aril colour at the second harvest was observed. In contrast, at the first harvest peel from T1 fruits showed higher $a^{*}$ values and similar $C^{\star}$ values to those in T0 but higher than those in T2, while $H^{\circ}$ values were lower than those in T0 and similar to those in T2. Also, arils from T1 fruits showed the highest $a^{*}$ and the lowest $H^{\circ}$ values, while $C^{*}$ values were similar to those in T0 but higher than those in T2. Arils from T1 fruits showed a significant increase compared with those from T0 fruits in fruit maturity index at the first harvest. However, the arils from T2 fruits at both harvests presented similar values to the arils from TO fruits for all the above fruit constituents and the maturity index. Irrigation treatment and harvest time did not affect the TEAC, sacarose, glucose, fructose, CA or MA contents in pomegranate arils. Arils from T1 and T2 fruits showed the highest TAC at the second harvest, while at the first harvest, the levels of this fruit constituent in T1 arils was higher than in T2 arils and similar to those observed for T0 arils.

\section{Conclusions}

Considerable differences were observed in the response of pomegranate fruits to both deficit irrigation treatments. In this sense, fruits from moderate water deficit plants showed a decrease in fruit growth, leading to a lower final fruit size and lower total yield, and some changes in colour and chemical characteristics, which reflected earlier ripening. In contrast, a more pronounced water stress during the second half of the fruit growth phase was more critical for fruit size than for the chemical characteristics of the fruit, probably because under this situation carbon assimilation should be allocated to the synthesis of primary metabolites, which did not exceeded the amount used for fruit growth to the detriment of the synthesis of carbon-based secondary metabolites. During ripening the peel of pomegranate fruits changes to show higher luminosity and greater red saturation. Also, the colour of the arils changes to a more perceptible red colour as a consequence of the increasing total anthocyanin content. However, neither the intense red colour of the arils nor their total phenolic compounds content was correlated with the juice antioxidant capacity. 


\title{
Pomegranate (Punica granatum L.) fruit response to different deficit irrigation conditions
}

\author{
C.D. Mellisho ${ }^{a}$, I. Egea ${ }^{a}$, A. Galindo ${ }^{a}$, P. Rodríguez ${ }^{b}$, J. Rodríguez ${ }^{b}$, W. Conejero ${ }^{a}$, F. Romojaro $^{\text {a }}$, \\ A. Torrecillas ${ }^{\mathrm{a}, \mathrm{c}, *}$ \\ a Centro de Edafología y Biología Aplicada del Segura (CSIC), P.O. Box 164, E-30100 Espinardo, Murcia, Spain \\ ${ }^{b}$ Dpto. Fisiología y Bioquímica, Instituto Nacional de Ciencias Agrícolas (INCA). Ctra. de Tapaste, km 3.5. San José de Las Lajas, La Habana, Cuba \\ c Unidad Asociada al CSIC de Horticultura Sostenible en Zonas Aridas (UPCT-CEBAS), Paseo Alfonso XIII s/n, E-30203 Cartagena, Murcia, Spain
}

\section{A R T I C L E I N F O}

\section{Article history:}

Available online 6 July 2012

\section{Keywords:}

Antioxidant capacity

Bioelements

Plant water relations

Total anthocyanin content

Total phenolic compounds

Water stress

\begin{abstract}
A B S T R A C T
No information exits on the effects of water stress on pomegranate (Punica granatum L.) fruits. In this paper, the influence of three irrigation treatments on the physical and chemical characteristics of the fruits of adult pomegranate trees was studied. Control (T0) plants were drip irrigated (60\% ETo from the beginning of the season to the end of the first half of linear fruit growth phase, $117 \%$ ETo during the second half of linear fruit growth phase and 99\% ETo during the end of fruit growth and ripening phase) in order to guarantee non-limiting soil water conditions, T1 plants were drip irrigated according to the criteria frequently used by the growers in the area ( $32 \%$ ETo from the beginning of the season to the end of the first half of linear fruit growth phase, 74\% ETo during the second half of linear fruit growth phase and $36 \%$ ETo during the end of fruit growth and ripening phase) and T2 plants were irrigated as T1, except during the second half of linear fruit growth phase, in which irrigation was withheld. To ensure the recovery of T2 plants re-irrigation was performed at the levels used in T0. T1 plants achieved a moderate water stress level, whereas T2 plants achieved a more pronounced water stress level, from which they completely recovered when plants were rewatered. During ripening the peel of pomegranate fruits changes to show higher luminosity and greater red saturation. Also, the colour of the arils changes to a more perceptible red colour as a consequence of the increasing total anthocyanin content. However, neither the intense red colour of the arils nor their total phenolic compounds content was correlated with the juice antioxidant capacity. Considerable differences were observed in the response of pomegranate fruits to both deficit irrigation treatments. In this sense, fruits from T1 plants showed a decrease in fruit growth, leading to a lower final fruit size and lower total yield, and some changes in colour and chemical characteristics, which reflected earlier ripening. In contrast, a more pronounced water stress during the second half of the fruit growth phase (T2) was more critical for fruit size than for the chemical characteristics of the fruit, probably because under this situation carbon assimilation should be allocated to the synthesis of primary metabolites, which did not exceeded the amount used for fruit growth to the detriment of the synthesis of carbon-based secondary metabolites.
\end{abstract}

(c) 2012 Elsevier B.V. All rights reserved.

\section{Introduction}

Pomegranate (Punica granatum L.) belongs to the family Punicaceae and is mainly confined to semi-arid mild-temperate to subtropical climates. Commercial orchards of pomegranate trees are now grown in many regions of the world, particularly in the Mediterranean Basin, where high quality fruits are obtained (Stover and Mercure, 2007; Holland et al., 2009).

\footnotetext{
* Corresponding author. Tel.: +34968 396330; fax: +34968 396213.

E-mail address: atorreci@cebas.csic.es (A. Torrecillas).
}

Despite the fact that pomegranate has frequently been considered a minor crop and is deemed either a small tree or a large shrub, its fruits are large berries with an edible part that has been extensively used in medicine by many traditional cultures due to its health-promoting benefits in the treatment or reduction in the risk of chronic disorders such as cancer, atherosclerosis, diabetes, blood pressure and other diseases (Langley, 2000; Michel et al., 2005; Katz et al., 2007; Lansky and Newman, 2007; Holland et al., 2009). According to Borochov-Neori et al. (2009), consumer satisfaction and producer profitability require that the pomegranate fruit excel in two aspects-health-related quality (antioxidative capacity) and fruit attractiveness (mainly colour and the taste of the arils and their juice). 
In this sense, the level of chemical and antioxidant compounds in pomegranate juice has been studied during fruit development and maturation (Gil et al., 1996; Kulkarni and Aradhya, 2005), in different environmental and cultivation conditions (Gil et al., 1995; Holland et al., 2009), and between cultivars (Melgarejo et al., 2000; Tzulker et al., 2007; Ozgen et al., 2008; Borochov-Neori et al., 2009). However, and in spite of the paramount importance of increasing water shortage in the most suitable regions for pomegranate growth hardly any reports exist on the effect of irrigation management on pomegranate fruit yield and quality. An exception is the work of Sonawane and Desai (1989), who indicated that by applying different irrigation regimes it is possible to control the desired time of fruit yield in pomegranates, while other authors have showed that irrigation has a positive effect on vegetative growth, yield and fruit weight (Prasad et al., 2003; Shaliendra and Narendra, 2005; Sulochanamma et al., 2005).

Fruit trees are highly sensitive to drought stress at particular phenological stages, such as fruit growth (Berman and Dejong, 1997; Xiloyannis et al., 2005), which in pomegranate trees occurs mainly during July and August (Melgarejo et al., 1997; Intrigliolo et al., 2011). In citrus plants, Domingo et al. (1996) showed that deficit irrigation during linear fruit growth induces a reduction in yield due to smaller fruit size at harvest. In contrast, although water deficit during the final stage of rapid fruit growth in stone fruit trees produces a decrease in final fruit size, beneficial aspects include increased total fruit soluble solids levels and earlier fruit ripening (Crisosto et al., 1994; Torrecillas et al., 2000; Besset et al., 2001).

The present study aimed to look at the effect of deficit irrigation on the physical and chemical characteristics of pomegranate fruits. For this, fully irrigated plants were compared with deficit irrigated plants, and others, which were submitted to an irrigation withholding period during the second half of linear fruit growth phase and then rewatered to encourage recovery.

\section{Materials and methods}

\subsection{Experimental conditions, plant material and treatments}

The experiment was carried out in 2009 at a farm located $22 \mathrm{~km}$ southeast of the city of Murcia (Spain) $\left(37^{\circ} 57^{\prime} \mathrm{N}, 0^{\circ} 56^{\prime} \mathrm{W}\right)$. The plant material consisted of own rooted 10 -year old pomegranate trees $(P$. granatum (L.)cv. Mollar de Elche). Tree spacing followed a $3 \mathrm{~m} \times 5 \mathrm{~m}$ pattern.

The soil was a xeric torriorthent with silt loam texture. Analytical data showed a high lime content ( $46 \%$ calcium carbonate), very low organic matter content $(0.92 \%)$, low cationic exchange capacity ( 7.93 mequiv. $100 \mathrm{~g}^{-1}$ ), and low available potassium and phosphorus levels. The irrigation water had an electrical conductivity of between 1.7 and $2.2 \mathrm{dS} \mathrm{m}^{-1}$ and $\mathrm{a} \mathrm{Cl}^{-}$concentration ranging from 36 to $48 \mathrm{mgl}^{-1}$. Pest control and fertilization practices were those usually used by the growers, and no weeds were allowed to develop within the orchard.

Micrometeorological data, namely air temperature, solar radiation, air relative humidity, rainfall and wind speed $2 \mathrm{~m}$ above the soil surface, were collected every $15 \mathrm{~min}$ by an automatic weather station located near the experimental site. Mean daily air vapour pressure deficit $\left(V D_{m}\right)$ was calculated according to Allen et al. (1998). Daily crop reference evapotranspiration (ETo, $927 \mathrm{~mm}$ ) was calculated using the Penman-Monteith equation(Allen et al., 1998).

From 3 April (day of the year (DOY) 93) to after second harvest (DOY 278) pomegranate plants were daily drip-irrigated during the night, using one lateral pipe parallel to the tree row and 3 emitters per tree, each delivering $41 \mathrm{~h}^{-1}$. In-line water meters were used to measure the water supplied to each experimental unit. Three irrigation treatments were considered for measurements. Control plants (treatment T0) were irrigated in order to guarantee nonlimiting soil water conditions $(60 \%$ ETo from the beginning of the season to the end of the first half of linear fruit growth phase, $117 \%$ ETo during the second half of linear fruit growth phase and 99\% ETo during the end of fruit growth and ripening phase). T1 plants were subjected to deficit irrigation throughout the season, according to the criteria frequently used by the growers in the area (32\% ETo from the beginning of the season to the end of the first half of linear fruit growth phase, 74\% ETo during the second half of linear fruit growth phase and 36\% ETo during the end of fruit growth and ripening phase). T2 treatment was irrigated as T1, except during the second half of linear fruit growth phase (DOY 209-243), in which irrigation was withheld. To ensure the recovery of T2 plants re-irrigation was performed at the levels used in T0 from DOY 244 to 278 (end of harvesting period) (see Section 2.3 for statistical design). Total water amounts applied were 711,382 and $319 \mathrm{~mm}$ for T0, T1 and T2 treatments, respectively. Actual precipitation was considered as part of applied water in T1 and T2 plants.

\subsection{Measurements}

Midday ( $12 \mathrm{~h}$ solar time) stem water potential ( $\psi_{\text {stem }}$ ) was measured on the south facing side and the middle third of the trees, in two fully developed leaves per tree of each replicate, enclosing leaves in a small black plastic bag covered with aluminium foil for at least $2 \mathrm{~h}$ before measurements in the pressure chamber (model 3005, Soil Moisture Equipment Co., Santa Barbara, CA, USA).

Midday leaf conductance $\left(g_{\text {lmd }}\right)$ in attached leaves was measured with a steady-state porometer (LI-1600, LICOR Inc., Lincon, USA) on the abaxial surface of the leaves and in a similar number and type of leaves as used for the $\Psi_{\text {stem }}$ measurements.

Marketable pomegranate fruits were harvested on two occasions, on 22 September (DOY 265) and 5 October (DOY 278). Ten fruits per replicate were weighed and measurements of equatorial diameter and maximum width of the fruit were made perpendicular to the polar axis, using a calliper. Then, the fruits were peeled by hand and the arils were weighted, homogenized and squeezed, in two-layered muslin cloth, to extract the complete juice. The juice was centrifuged $(1200 \mathrm{~g})$ at $4{ }^{\circ} \mathrm{C}$ and stored at $-70^{\circ} \mathrm{C}$ until chemi$\mathrm{cal}$ analyses were performed. Total soluble solids (TSS) in the juice were measured using a digital refractometer (ATAGO RX-5000, calibrated using distilled water). Titratable acidity (TA) was measured by titrating an aliquot of juice with $0.1 \mathrm{~N} \mathrm{NaOH}$ and expressed as grams of citric acid per $100 \mathrm{~mL}$ of juice. Aliquots of fruit arils were oven-dried at $105^{\circ} \mathrm{C}$ to constant weight to measure the moisture content.

Peel colour (four different measurements at four equidistant points on the equatorial region of each individual fruit) and aril colour (four measurements were made on opposite sites of the equatorial area of each fruit) were assessed. A Minolta CR 2000 colorimeter (Osaka, Japan) was used and results were expressed in the CIELAB $L^{*}, a^{*}, b^{*}$ system. The mean values for lightness $\left(L^{*}\right)$, redgreenness $a^{*}$ and blue-yellowness $b^{*}$ parameters for each fruit were calculated. The objective colour was calculated as chromaticity or chroma $\left(C^{*}=\left(a^{* 2}+b^{* 2}\right)^{1 / 2}\right)$ and hue angle $\left(H^{\circ}=\arctan \left(b^{*} / a^{*}\right)\right)$

The sugar and organic acid contents were measured in filtered juice passed through Durapore $0.45 \mu \mathrm{m}$ HV (Milipore Corporation). Sugars and organic acids were quantified by a Shimadzu HPLC (Kyoto, Japan) equipped with an ion exchange column (ION 300, Teknochroma) and two detectors: a Shimadzu Refractive Index Detector (Kyoto, Japan), at $30^{\circ} \mathrm{C}$, for the detection of sugars, and, in tandem, a Shimadzu UV-Vis detector (Kyoto, Japan) for the organic acids. The mobile phase was $5 \mathrm{mmol} / \mathrm{L} \mathrm{H}_{2} \mathrm{SO}_{4}$ at a flow rate of $0.4 \mathrm{~mL} / \mathrm{min}$. The detection wavelength was $230 \mathrm{~nm}$ for citric (CA) and malic (MA) acids. The sugar and organic acid concentrations 
in the juice were obtained using calibration curves for each compound.

The ABTS $^{*} \quad$ (2,20-azinobis-(3-ethylbenzothiazoline-6sulfonate) radical anion solution was generated by incubating a

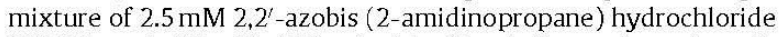
(ABAP) and $20 \mathrm{mM}$ 2,2'-azinobis (3-ethylbenzothyazolyne-6sulfonate) $\left(\mathrm{ABTS}_{2}{ }^{-}\right)$stock solution in $100 \mathrm{~mL}$ of phosphate buffer ( $100 \mathrm{mM}$ phosphate and $150 \mathrm{mM} \mathrm{NaCl}, \mathrm{pH} 7.4$ ) at $60^{\circ} \mathrm{C}$ for $6 \mathrm{~min}$. The absorbance at $734 \mathrm{~nm}$ was measured to check ABTS ${ }^{*}$ formation (Egea et al., 2007). $50 \mu \mathrm{L}$ of diluted (1:20) juice were mixed with $1.95 \mu \mathrm{L}$ of the radical solution to measure the antioxidant activity at $734 \mathrm{~nm}$ for a period of $6 \mathrm{~min}$. The decrease in absorbance at $734 \mathrm{~nm}$ for a period of $6 \mathrm{~min}$ after the addition of each compound was used to calculate the Trolox equivalent antioxidant capacity (TEAC). A calibration curve was prepared with different concentrations of Trolox (water-soluble-analogous to vitamin E). The TEAC activity was calculated according to Egea et al. (2007), and the results were expressed as $\mu \mathrm{M}$ Trolox showing the same antioxidant capacity as the analyzed sample (Trolox equivalent).

Total phenolic compounds (TPC) were determined according to Singleton et al. (1999), using Folin-Ciocalteu reagent. An aliquot of filtered juice was diluted with $0.4 \mathrm{~mL}$ of phosphate buffer $(50 \mathrm{mM}$, $\mathrm{pH}=7.8)$. Folin-Ciocalteu reagent $(2.5 \mathrm{~mL})$ was added and the content of the flask mixed thoroughly. After $8 \mathrm{~min}, \mathrm{~N}_{\mathrm{AA}} \mathrm{CO}$ solution $(10 \mathrm{~mL}, 10 \%, \mathrm{w} / \mathrm{v})$ was added and the samples were incubated in a water bath at $50^{\circ} \mathrm{C}$ for $5 \mathrm{~min}$. The resulting blue colour was measured spectrophotometrically at $760 \mathrm{~nm}$. The concentration of the total phenolic compounds in juice was determined by comparison with the absorbance of analytical grade phenol standard gallic acid at different concentrations. Results were expressed as mg of gallic acid per $100 \mathrm{~mL}$ of juice (Egea et al., 2010).

Total anthocyanin content (TAC) was determined by a $\mathrm{pH}$ differential method with two buffer systems, sodium acetate buffer, $\mathrm{pH} 4.5(0.4 \mathrm{M})$ and potassium chloride buffer $\mathrm{pH} 1.0(0.025 \mathrm{M})$ (Giusti et al., 1999). Pomegranate juice $(0.4 \mathrm{~mL})$ was mixed with $3.6 \mathrm{~mL}$ of corresponding buffers and read against water as blank at $510 \mathrm{~nm}$ and $700 \mathrm{~nm}$. The absorbance $(A)$ was calculated as $A=\left(A_{510}-A_{700}\right) \mathrm{pH}_{1.0}-$ $\left(A_{510}-A_{700}\right) \mathrm{pH}_{4.5}$. The total anthocyanin content was calculated by following the equation $\mathrm{TAC}=(A \times \mathrm{MW} \times \mathrm{DF} \times 100 / \mathrm{MA})$, where $A=$ absorbance; $M W=$ molecular weight (449.2); $D F=$ dilution factor (10); MA=molar absorptivity of cyaniding-3-glucoside (26.900), and the result were expressed as mg cyaniding-3glucoside $/ 100 \mathrm{~mL}$ of pomegranate juice.

Aliquots of fruit arils were oven-dried at $85^{\circ} \mathrm{C}$ to constant weight and finely crushed in an agate mortar. Arils $\mathrm{N}$ concentration was measured using a Thermo-Finnigan 1112 EA elemental analyzer (Thermo-Finnigan, Milan, Italy). Aril powder was subjected to nitroperchloric acid attack ( $5: 3, \mathrm{v} / \mathrm{v})$ in a microwave oven (CEM Mars Xpress, NC, USA) reaching $200^{\circ} \mathrm{C}$ in $20 \mathrm{~min}$ and holding at this temperature for $2 \mathrm{~h}$. The $\mathrm{P}, \mathrm{K}, \mathrm{Ca}, \mathrm{Mg}, \mathrm{S}, \mathrm{Fe}, \mathrm{Mn}, \mathrm{Zn}, \mathrm{Cu}$ and $\mathrm{B}$ concentrations of the arils were quantified by inductively coupled plasma emission optical spectrometry (Iris Intrepid II, Thermo Electron Corporation, Franklin, USA).

\subsection{Statistical design and analysis}

The design of the experiment was completely randomized with four replications, each replication consisting of three adjacent tree rows, each with eleven trees. Measurements were taken on the inner tree of the central row of each replicate, which were very similar in appearance (leaf area, trunk cross sectional area, height, ground shaded area, etc.), while the other trees served as border trees. Data were analyzed using SPSS software (SPPS, 2002). Analysis of variance was performed and mean values were compared by an $\mathrm{LSD}_{0.05}$ test. Values for each replicate were averaged before the mean and the standard error of each treatment were calculated.

\section{Results}

During the experimental period, average daily maximum and minimum air temperatures were 29.1 and $16.3^{\circ} \mathrm{C}$, respectively. $\mathrm{VPD}_{\mathrm{m}}$ ranged from 0.16 to $4.0 \mathrm{kPa}$, and accumulated ETo was $927 \mathrm{~mm}$ (Fig. 1). Total rainfall achieved $125 \mathrm{~mm}$, which took place mainly on DOY 270 and 271 (64.6 mm) (Fig. 1).

$\Psi_{\text {stem }}$ values for T0 plants were high and almost constant during the experimental period, whereas $\Psi_{\text {stem }}$ values for T2 plants gradually decreased from the beginning of the water withholding period, reaching minimum values at the end of the stress period $(-1.98 \mathrm{MPa})$ and recovering to T0 levels when irrigation was resumed (Fig. 2A). The $\Psi_{\text {stem }}$ values of T1 plants were very similar to those of $\mathrm{T} 2$ plants from the beginning of the measurement period (DOY 110) to DOY 183. From DOY 224 to DOY 243, $\Psi_{\text {stem values of }}$ $\mathrm{T} 1$ plants were intermediate between those of $\mathrm{T} 0$ and $\mathrm{T} 2$ plants, and showed lower values than T0 and T2 from DOY 247 onwards, except at the end of the experimental period when $\Psi_{\text {stem }}$ increased due to rainfall (Figs. 1 and $2 \mathrm{~A}$ ).

Prior to DOY 219 no differences between treatments were observed in $g_{\text {Imd }}$ values (Fig. 2B). However, withholding irrigation in T2 plants induced a gradual decrease in $g_{\text {Imd }}$, which reached minimum values at the end of the stress period $\left(146 \mathrm{mmol} \mathrm{m}^{-2} \mathrm{~s}^{-1}\right)$ before recovering through rewatering. The $g_{\text {Imd }}$ values of T1 plants lay between T0 and T2 values from DOY 224 to DOY 243, remaining near constant from that time to DOY 262 and increasing at the end of the measurements period when rainfall occurred (Figs. 1 and 2B).

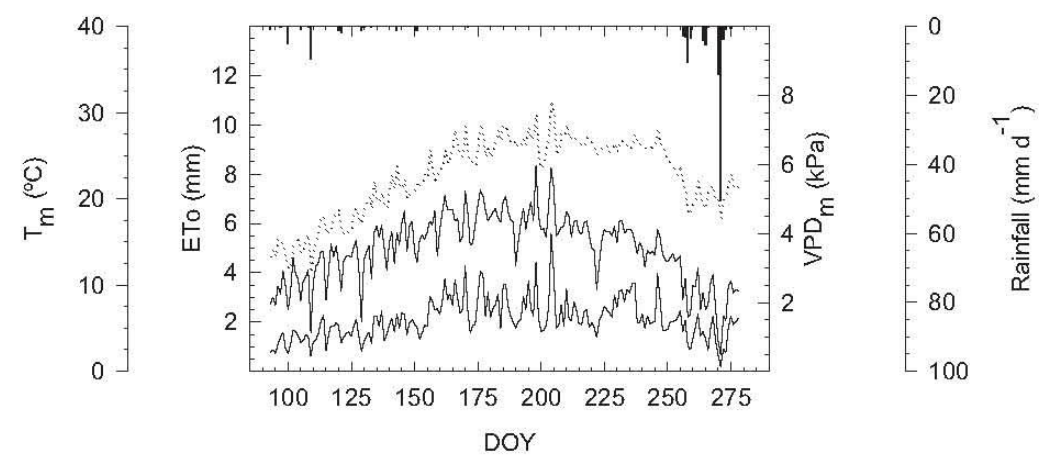

Fig. 1. Daily crop reference evapotranspiration (ETo, thick line), daily mean air temperature ( $T_{\mathrm{m}}$, dotted line), mean daily air vapour pressure deficit (VPD $\mathrm{m}_{\mathrm{m}}$ ) (thin line) and daily rainfall (vertical bars) during the experimental period. 


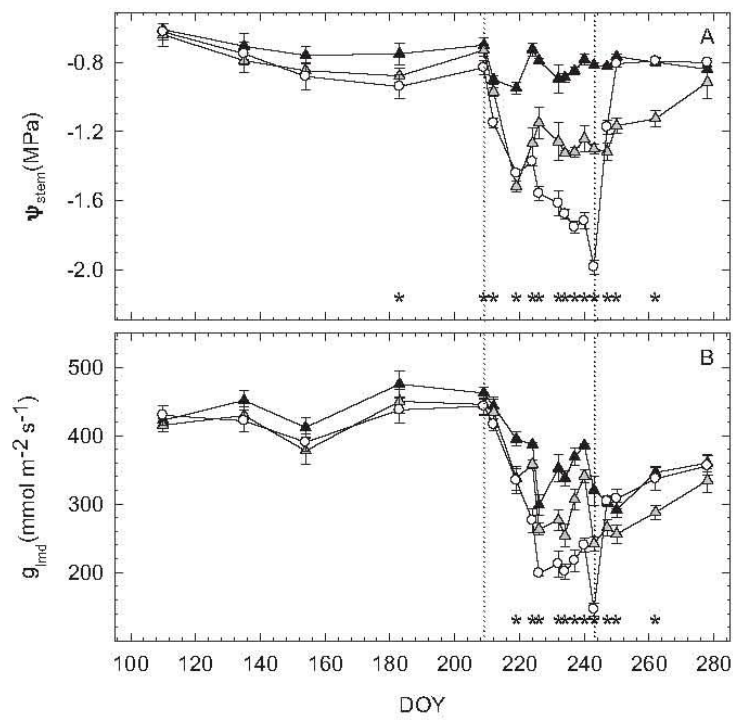

Fig. 2. Midday stem water potential $\left(\Psi_{\text {stem }}, \mathrm{A}\right)$ and midday leaf conductance (gimd, B) values (mean \pm SE, not shown when smaller than symbols) for pomegranate plants in T0 (black triangles), T1 (grey triangles) and T2 (circles) treatments during the experimental period. Asterisks indicate significant differences between treatments $(P \leq 0.05)$. Vertical dotted lines indicate, from left to right, the beginning and the end, respectively, of the water withholding period.

Table 1

Effect of irrigation treatments on pomegranateyield $\left(\mathrm{kg} \mathrm{tree}^{-1}\right)$, average fruitweight (FW, g), equatorial diameter (ED, mm), peel content (PC, \%) and moisture content (MC,\%) at both harvest. Means within a column for each harvest that do not have a common letter are significantly different by $\mathrm{LSD}_{0.05}$ test.

\begin{tabular}{lllllll}
\hline Harvest & Treatment & Yield & FW & ED & PC & MC \\
\hline I & T0 & $49.80 \mathrm{a}^{*}$ & $307.71 \mathrm{a}$ & $83.90 \mathrm{a}$ & $35.94 \mathrm{a}$ & $82.61 \mathrm{a}$ \\
& T1 & $42.46 \mathrm{ab}$ & $299.33 \mathrm{a}$ & $83.51 \mathrm{a}$ & $32.49 \mathrm{a}$ & $82.16 \mathrm{a}$ \\
& T2 & $38.34 \mathrm{~b}$ & $265.20 \mathrm{~b}$ & $80.88 \mathrm{~b}$ & $35.31 \mathrm{a}$ & $82.14 \mathrm{a}$ \\
II & T0 & $15.70 \mathrm{a}$ & $315.56 \mathrm{a}$ & $85.20 \mathrm{a}$ & $38.31 \mathrm{a}$ & $82.23 \mathrm{a}$ \\
& T1 & $3.36 \mathrm{~b}$ & $284.78 \mathrm{~b}$ & $81.89 \mathrm{~b}$ & $33.65 \mathrm{~b}$ & $82.15 \mathrm{a}$ \\
& T2 & $8.79 \mathrm{ab}$ & $251.03 \mathrm{~b}$ & $79.01 \mathrm{c}$ & $35.16 \mathrm{ab}$ & $82.33 \mathrm{a}$ \\
\hline
\end{tabular}

- Statistically significant effect of harvest time.

The total marketable pomegranate yield in T1 plants was similar to that observed in T2 plants and lower than in T0 plants (data not shown). The decrease in T1 total marketable yield was due to the lower yield, fruit size and average fruit weight at the second harvest, since, at the first harvest, when only fruits of marketable size and colour were harvested, $\mathrm{T} 0$ and $\mathrm{T} 1$ plants presented similar yield and fruit characteristics (Table 1). The decrease in T2 total yield was due to the presence of fruits showing the lowest size and average weight at both harvests. In contrast with $\mathrm{T} 2$ treatment, the $\mathrm{T} 1$ treatment induced reduced peel content at the second harvest compared with
Table 3

Effect of irrigation treatments on pomegranate arils total soluble solids (TSS, ${ }^{\circ}$ Brix) titrable acidity (TA, \% citric acid), pH and maturity index (TSS/TA) at both harvest Means within a column for each harvest that do not have a common letter are significantly different by $L_{0.05}$ test. Asterisks indicate a statistically significant effect of harvest time.

\begin{tabular}{llllll}
\hline Harvest & Treatment & TSS & TA & $\mathrm{pH}$ & TSS/TA \\
\hline I & T0 & $15.5 \mathrm{~b}$ & $0.26 \mathrm{a}^{*}$ & $3.6 \mathrm{a}^{*}$ & $60.52 \mathrm{~b}^{*}$ \\
& T1 & $16.9 \mathrm{a}$ & $0.24 \mathrm{a}$ & $3.4 \mathrm{a}$ & $69.35 \mathrm{a}$ \\
& T2 & $15.7 \mathrm{~b}$ & $0.25 \mathrm{a}$ & $3.5 \mathrm{a}$ & $63.84 \mathrm{ab}$ \\
II & T0 & $16.1 \mathrm{a}$ & $0.23 \mathrm{a}$ & $4.0 \mathrm{ab}$ & $69.48 \mathrm{a}$ \\
& T1 & $16.6 \mathrm{a}$ & $0.23 \mathrm{a}$ & $3.8 \mathrm{~b}$ & $72.90 \mathrm{a}$ \\
& T2 & $16.4 \mathrm{a}$ & $0.23 \mathrm{a}$ & $4.2 \mathrm{a}$ & $71.18 \mathrm{a}$ \\
\hline
\end{tabular}

- Statistically significant effect of harvest time.

T0 fruits. The fruit moisture content was not modified by deficit irrigation in $\mathrm{T} 1$ and $\mathrm{T} 2$ plants (Table 1).

Changes in pomegranate peel and aril colour from the first to the second harvest were observed (Table 2 ). In this sense, peel $L^{*}$ values increased from the first to the second harvest, while $\mathrm{H}^{\circ}$ decreased. Also, at the first harvest, fruit arils showed lower $a^{*}$ and $C^{*}$ and higher $H^{\circ}$ values than at the second harvest. No significant effect of the irrigation treatment on pomegranate peel or aril colour at the second harvest was observed. In contrast, at the first harvest peel from T1 fruits showed higher $a^{*}$ values and similar $C^{*}$ values to those in T0 but higher than those in T2, while $H^{\circ}$ values were lower than those in T0 and similar to those in T2 (Table 2). Also, arils from T1 fruits showed the highest $a^{*}$ and the lowest $H^{\circ}$ values, while $C^{*}$ values were similar to those in To but higher than those in T2 (Table 2).

Pomegranate arils showed an increase in $\mathrm{pH}$ and maturity index (TSS/TA) and a decrease in TA values from the first to the second harvest (Table 3 ). Arils from T1 fruits showed a significant increase compared with those from T0 fruits, both in their TSS and TSS/TA values, at the first harvest (Table 3 ). However, the arils from T2 fruits at both harvests presented similar values to the arils from $\mathrm{T} 0$ fruits for all the above fruit constituents and the maturity index (Table 3).

Irrigation treatment and harvest time did not affect the TEAC, sacarose, glucose, fructose, CA or MA contents in pomegranate arils (Table 4). TPC and TAC in pomegranate arils increased form the first to the second harvest (Table 4). Arils from T1 and T2 fruits showed the highest TAC at the second harvest, while at the first harvest, the levels of this fruit constituent in T1 arils was higher than in $\mathrm{T} 2$ arils and similar to those observed for T0 arils (Table 4).

The most abundant bioelements in pomegranate arils were $\mathrm{N}, \mathrm{K}$, $\mathrm{P}, \mathrm{S}$ and $\mathrm{Mg}$, followed, in descending order, by $\mathrm{Ca}, \mathrm{Fe}, \mathrm{Zn}, \mathrm{B}, \mathrm{Cu}$ and $\mathrm{Mn}$ (Table 5). Some changes in the aril nutrient content between the pomegranates harvested at the first and at the second harvest were observed. In this sense, at the second harvest $\mathrm{N}, \mathrm{P}, \mathrm{S}, \mathrm{Fe}, \mathrm{Cu}$ and $\mathrm{B}$ contents were low and the $\mathrm{K}$ content was higher than at the first harvest (Table 5). At the first harvest, while all the considered bioelements presented similar levels in the arils from $\mathrm{T} 0$ and $\mathrm{T} 2$

Table 2

Effect of irrigation treatments on peel and arils pomegranate lightness $\left(L^{*}\right)$, red-greenness $\left(a^{*}\right)$, chroma $\left(C^{*}\right)$ and hue angle $\left(H^{\circ}\right)$ values at both harvest. Means within a column for each harvest that do not have a common letter are significantly different by $L_{S D_{0.05}}$ test. Asterisks indicate a statis tically significant effect of harvest time.

\begin{tabular}{|c|c|c|c|c|c|c|c|c|c|}
\hline \multirow[b]{2}{*}{ Harvest } & \multirow[b]{2}{*}{ Treatment } & \multicolumn{2}{|l|}{$L^{*}$} & \multicolumn{2}{|l|}{$a^{*}$} & \multicolumn{2}{|l|}{$C^{*}$} & \multicolumn{2}{|l|}{$H^{\circ}$} \\
\hline & & Peel & Arils & Peel & Arils & Peel & Arils & Peel & Arils \\
\hline \multirow[t]{3}{*}{ I } & T0 & $71.4 a^{\circ}$ & $41.5 \mathrm{a}$ & $4.7 \mathrm{~b}$ & $15.3 \mathrm{~b}^{*}$ & $41.9 \mathrm{ab}$ & $21.8 \mathrm{ab}^{*}$ & $80.7 a^{*}$ & $43.9 a^{\circ}$ \\
\hline & T1 & $72.0 \mathrm{a}$ & $40.4 a$ & $23.7 \mathrm{a}$ & $21.6 \mathrm{a}$ & $42.5 \mathrm{a}$ & $24.5 \mathrm{a}$ & $72.7 \mathrm{~b}$ & $27.6 \mathrm{~b}$ \\
\hline & T2 & 71.6a & $41.8 \mathrm{a}$ & $7.1 \mathrm{~b}$ & $13.2 \mathrm{c}$ & $40.6 \mathrm{~b}$ & $18.5 b$ & $77.5 \mathrm{ab}$ & 44.3a \\
\hline \multirow[t]{3}{*}{ II } & T0 & $76.2 \mathrm{a}$ & $40.7 a$ & $14.5 \mathrm{a}$ & $22.9 a$ & 41.1a & $24.7 \mathrm{a}$ & $70.9 \mathrm{a}$ & $21.8 \mathrm{a}$ \\
\hline & T1 & 77.1a & $39.4 a$ & $14.6 a$ & $24.5 \mathrm{a}$ & $41.7 \mathrm{a}$ & $26.2 a$ & 72.1a & $19.8 \mathrm{a}$ \\
\hline & $\mathrm{T} 2$ & $75.8 \mathrm{a}$ & $38.8 \mathrm{a}$ & $10.4 a$ & $23.7 \mathrm{a}$ & 41.6a & $25.3 a$ & $73.9 \mathrm{a}$ & $19.7 \mathrm{a}$ \\
\hline
\end{tabular}

- Statistically significant effect of harvest time. 
Table 4

Effect of irrigation treatments on pomegranate arils total phenolic compounds content (TPC, $\mathrm{mg} / 100 \mathrm{~mL}$ ), total anthocyanin content (TAC, mg/100 mL), trolox equivalent antioxidant activity (TEAC, $\mu$ M trolox), sacarose $(g / 100 \mathrm{~mL})$, glucose $(g / 100 \mathrm{~mL})$, fructose $(\mathrm{g} / 100 \mathrm{~mL})$, citric acid $(\mathrm{CA}, \mathrm{g} / 100 \mathrm{~mL})$ and $\mathrm{malic}$ acid $(\mathrm{MA}, \mathrm{g} / 100 \mathrm{~mL})$ at both harvest. Means within a column for each harvest that do not have a common letter are significantly different by LSD $_{0.05}$ test Asterisks indicate a statistically significant effect of harvest time.

\begin{tabular}{|c|c|c|c|c|c|c|c|c|c|}
\hline Harvest & Treatment & TPC & TAC & TEAC & Sacarose & Glucose & Fructose & $\mathrm{CA}$ & MA \\
\hline \multirow[t]{3}{*}{ I } & T0 & $127.9 \mathrm{a}^{*}$ & $3.67 \mathrm{ab}^{*}$ & 109.71a & $0.15 a$ & $5.40 \mathrm{a}$ & $5.92 a$ & $0.042 a$ & $0.164 \mathrm{a}$ \\
\hline & $\mathrm{T} 1$ & $128.9 a$ & $4.91 \mathrm{a}$ & $101.36 \mathrm{a}$ & $0.12 \mathrm{a}$ & $6.05 a$ & $6.63 \mathrm{a}$ & $0.072 \mathrm{a}$ & $0.189 \mathrm{a}$ \\
\hline & $\mathrm{T} 2$ & $146.3 \mathrm{a}$ & $3.06 \mathrm{~b}$ & 114.14a & $0.15 a$ & $5.68 \mathrm{a}$ & $6.20 \mathrm{a}$ & $0.070 \mathrm{a}$ & $0.195 \mathrm{a}$ \\
\hline \multirow[t]{3}{*}{ II } & T0 & $179.2 \mathrm{a}$ & $5.91 \mathrm{~b}$ & $105.21 \mathrm{a}$ & $0.15 a$ & $5.82 \mathrm{a}$ & $6.37 \mathrm{a}$ & $0.035 a$ & $0.167 \mathrm{a}$ \\
\hline & $\mathrm{T} 1$ & $174.4 a$ & $9.38 \mathrm{a}$ & $103.51 \mathrm{a}$ & $0.15 a$ & $5.87 a$ & $6.41 \mathrm{a}$ & $0.065 a$ & $0.210 \mathrm{a}$ \\
\hline & $\mathrm{T} 2$ & $192.0 \mathrm{a}$ & $8.33 \mathrm{a}$ & $115.04 \mathrm{a}$ & $0.13 \mathrm{a}$ & $6.59 \mathrm{a}$ & $7.22 \mathrm{a}$ & $0.068 \mathrm{a}$ & $0.193 a$ \\
\hline
\end{tabular}

- Statistically significant effect of harvest time.

Table 5

Effect of irrigation treatments on some mineral nutrients contents $(\mathrm{mg} / 100 \mathrm{~g} \mathrm{DW})$ in arils of pomegranate at both harvests. Means within a column for each harvest that do not have a common letter are significantly different by $\mathrm{LSD}_{0.05}$ test. As terisks indicate a statistically significant effect of harvest time.

\begin{tabular}{|c|c|c|c|c|c|c|c|c|c|c|c|c|}
\hline Harvest & Treatment & $\mathrm{N}$ & $\mathrm{P}$ & K & $\mathrm{Ca}$ & $\mathrm{Mg}$ & $S$ & $\mathrm{Fe}$ & $\mathrm{Mn}$ & $\mathrm{Zn}$ & $\mathrm{Cu}$ & B \\
\hline \multirow[t]{3}{*}{ I } & T0 & $1171 a^{*}$ & $212 \mathrm{a}^{*}$ & $1038 a^{*}$ & $26 a b$ & $82 a$ & $109 a^{\circ}$ & $2.92 \mathrm{a}^{\circ}$ & $0.50 \mathrm{ab}$ & $1.38 \mathrm{a}$ & $0.81 \mathrm{~b}^{\circ}$ & $1.34 a^{*}$ \\
\hline & $\mathrm{T} 1$ & $957 \mathrm{~b}$ & $190 \mathrm{~b}$ & $893 \mathrm{~b}$ & $22 \mathrm{~b}$ & $63 \mathrm{~b}$ & $94 \mathrm{~b}$ & $2.81 \mathrm{a}$ & $0.44 \mathrm{~b}$ & $1.20 \mathrm{a}$ & $1.07 \mathrm{a}$ & $0.98 \mathrm{~b}$ \\
\hline & $\mathrm{T} 2$ & $1124 a$ & $208 \mathrm{ab}$ & $977 \mathrm{ab}$ & $30 \mathrm{a}$ & $80 \mathrm{a}$ & 106ab & $4.81 \mathrm{a}$ & $0.53 a$ & $1.43 a$ & $0.95 \mathrm{ab}$ & 1.17ab \\
\hline \multirow[t]{3}{*}{ II } & T0 & $1075 a$ & $123 a$ & $1278 a$ & $31 a$ & $80 a$ & $81 a$ & $1.35 \mathrm{a}$ & $0.49 \mathrm{a}$ & $1.48 \mathrm{a}$ & $0.65 \mathrm{a}$ & $0.84 a$ \\
\hline & $\mathrm{T} 1$ & 1034ab & $120 \mathrm{a}$ & $1224 a$ & $30 a$ & $77 a$ & $70 \mathrm{a}$ & $1.47 \mathrm{a}$ & $0.42 \mathrm{a}$ & $1.40 \mathrm{a}$ & $0.62 \mathrm{a}$ & $1.04 a$ \\
\hline & T2 & $977 \mathrm{~b}$ & 115a & $1229 a$ & $29 a$ & $76 a$ & $74 a$ & $1.07 \mathrm{a}$ & $0.45 a$ & $1.26 \mathrm{a}$ & $0.62 \mathrm{a}$ & $1.06 \mathrm{a}$ \\
\hline
\end{tabular}

- Statistically significant effect of harvest time

fruits, the arils from T1 fruits showed lower N, P, K, Mg, S and B contents and higher Cu content than T0 arils. However, at the second harvest, no effect of irrigation treatment on the bioelements contents was found, except in the case of $\mathrm{N}$, which showed the lowest values in $\mathrm{T} 2$ arils (Table 5 ).

\section{Discussion}

The fact that $\mathrm{T} 0$ and $\mathrm{T} 1$ plants showed clear differences in their plant water status (Fig. 2) could be considered evidence that the irrigation criteria frequently used by the growers in the area (T1 treatment) did not satisfy pomegranate water requirements. The rapid recovery of $\Psi_{\text {stem }}$ values in T2 plants recorded when irrigation was resumed (Fig. 2A), has frequently been observed in other woody crops also subjected to severe water stress (Torrecillas et al., 1995, 1996; Ruiz-Sánchez et al., 1997; Ortuño et al., 2006). However, the rapid recovery of $g_{1 m d}$ values observed in T2 plants when irrigation was resumed suggested that, at the level of water stress reached at the end of stress period, stomatal aperture was controlled directly mainly by a hydroactive mechanism (Torrecillas et al., 1995), and a more severe water stress would probably have been necessary to cause a significant delay on the recovery of stomatal opening after rehydration (Ruiz-Sánchez et al., 1997). For these reasons, it can be concluded that T1 plants achieved a moderate water stress level before DOY 270-271, when heavy rainfall occurred (Figs. 1 and 2), whereas T2 plants achieved a more pronounced water stress level, from which they completely recovered when plants were rewatered (Figs. 1 and 2).

Deficit irrigation in T1 plants showed that moderate water deficit during fruit growth affects not only yield and final fruit size (Table 1) but also aril and peel colour and some fruit chemical characteristics, especially in fruits from the first harvest, such as TSS, TSS/TA (earlier maturity), N, P, K, Mg, S, B and Cu contents (Tables 2-5). In addition, at the end of the ripening period ( $\mathrm{sec}$ ond harvest) fruits from $\mathrm{T} 1$ plants showed a significant decrease in peel content (Table 1), which could be related with fruit splitting incidence (Prasad et al., 2003).

To explain the fact that pomegranate arils from $\mathrm{T} 2$ fruits showed very similar overall chemical characteristics to arils from T0 fruits (Tables 2-5), it is important to take into consideration that some authors showed that it is not possible to establish a linear correlation between water stress and secondary metabolite contents (Mattson and Haack, 1987; Gobbo-Neto and Lopes, 2007). In this sense, Horner (1990) proposed a model to predict the concentration of phenolic compounds in function on water status, which was based in a quadratic relationship between both variables. Thus, mild osmotic stress may leads to a reduction in plant growth, increasing concentration of nonnitrogenous secondary metabolites. However, when water stress increases, stomatal regulation takes place and $\mathrm{CO}_{2}$ assimilation is reduced. Under this situation, carbon should be preferentially allocated to the synthesis of primary metabolites, which did not exceeded the amount used for fruit growth to the detriment of the synthesis of carbon-based secondary metabolites.

Also, it is important to emphasize that during water stress most fruits act as strong sinks of photosynthates, which are available when irrigation is restored, promoting higher fruit growth rates (Cohen and Goell, 1984; Mills et al., 1996; Caspari et al., 1994). However, this compensatory fruit growth rate was not observed in the $\mathrm{T} 2$ fruits, because they showed the lowest size and average weight at both harvests (Table 1), indicating that water stress during the second half of linear fruit growth phase was critical for fruit growth.

Although there were only 13 days from the first to the second harvest, some important changes were detected in the fruit characteristics. In this sense, the decrease in TA and increase in $\mathrm{pH}$ and TSS/TA ratio is an inherent process during the ripening of pomegranate, which imparts the characteristic flavour to the juice (Cemeroglu et al., 1992; Al-Maiman and Ahmad, 2002). Changes in fruit peel $L^{*}$ and $H^{\circ}$ values indicated an evolution to higher luminosity and greater red saturation, while the changes in the $a^{*}, C^{*}$ and $H^{\circ}$ values of the arils indicated an evolution towards a more intense red colour, from the first to the second harvest (Table 2). These results reflect the increase in TAC observed in the fruit arils (Table 4) and the results observed by Hernández et al. (1999), who showed an increase in juice pigmentation during pomegranate fruit ripening and identified six anthocyanin pigments responsible for the red colour of pomegranate juice.

The fact that TAC increased through the effect of harvesting, even though similar TEAC levels were found at both harvest times, confirmed that juice antioxidant capacity is not linearly correlated 
with the red colour intensity of the arils and that the anthocyanins in the pomegranate juice are not major contributors to the antioxidant capacity exhibited by the juice (Borochov-Neori et al., 2009). Moreover, the fact that TEAC levels were similar at both harvest times, although TPC increased from the first to the second harvest, does not agree with the linear relationship between soluble phenolic levels and antioxidant capacity indicated by Borochov-Neori et al. (2009) supporting the idea that the phenolic compounds are the main contributors to the antioxidant activity in pomegranate juice.

The overall bioelements levels in pomegranate arils (Table 5) at both harvest times differed substantially with respect to those reported by Chauhan et al. (1991) and Al-Maiman and Ahmad (2002). The clearly higher levels of $\mathrm{P}, \mathrm{K}, \mathrm{Mg}, \mathrm{Fe}, \mathrm{Zn}$ and $\mathrm{Cu}$ in our pomegranate arils, and the fact that the effect of harvest time on $\mathrm{P}$, $\mathrm{Fe}$, and $\mathrm{Cu}$ was the opposite to the change indicated by Al-Maiman and Ahmad (2002), could be ascribed to significant differences in the cultivar's efficiency for nutrient uptake, edaphoclimatic conditions or cultural practices (Fadavi et al., 2005).

\section{Conclusions}

The above mentioned results indicated that during the ripening phase pomegranate fruits change in order to show a peel with higher luminosity and red saturation. Also, aril colour changes to exhibit a more perceptible red colour as a consequence of the increasing total anthocyanin content. However, neither the red colour intensity of the arils nor its total phenolic compounds content was correlated with the juice antioxidant capacity. Considerable differences were observed in the response of pomegranate fruits to both deficit irrigation treatments. Fruits from plants under moderate water stress level (T1) showed a decrease in fruit growth, inducing a lower final fruit size and lower total yield, accompanied by changes in colour and fruit chemical characteristics, which reflected earlier ripening. In contrast, a more pronounced water stress level during the second half of fruit growth phase (T2) was more critical for fruit size than for their chemical characteristics, probably because under this situation carbon assimilation should be allocated to the synthesis of primary metabolites, which did not exceeded the amount used for fruit growth to the detriment of the synthesis of carbon-based secondary metabolites.

\section{Acknowledgments}

To Prof. Dr. Manuel Sánchez-Díaz in recognition of his exemplary qualities as a human being and scientific. We are grateful to Ministerio de Ciencia e Innovaciôn (MICINN) (CICYT/FEDER AGL2010-19201-C04-01AGR) and Agencia Española de Cooperación Internacional para el Desarrollo (AECID) (D/023231/09) for grants to the authors. We thank the Ministerio de Ciencia e Innovaciôn (MICINN) for the FPI research fellowship to C.D. Mellisho and A. Galindo.

\section{References}

Allen, R.G., Pereira, R.S., Raes, D., Smith, M., 1998. Crop EvapotranspirationGuidelines for Computing Crop Water Requirements, v. 56. FAO Irrigation and Drainage 56, Rome

Al-Maiman, S.A., Ahmad, D., 2002. Changes in physical and chemical properties during pomegranate (Punica granatum L.) fruit maturation. Food Chemistry 76 , 437-441.

Berman, M.E., DeJong, T.M., 1997. Crop load and water stress on daily stem growth in peach (Prunus persica). Tree Physiology 17, 467-472.

Besset, J., Génard, M., Girard,T., Serra, V.,Bussi, C., 2001. Effect of waterstress applied during the final stage of rapid growth of peach trees (cv. Big-Top). Scientia Horticulturae 91, 289-303.

Borochov-Neori, H., Judeinstein, S., Tripler, E., Harari, M., Greenberg, A., Shomer, I., Holland, D., 2009. Seasonal and cultivar variations in antioxidant and sensory quality of pomegranate (Punica granatum L.) fruit. Journal of Food Composition and Analysis 22, 189-195

Caspari, H.W., Behboudian, M.H., Chalmers, D.J., 1994. Water use, growth, and fruit yield of 'Hosui' Asian pears under deficit irrigation. Journal of the American Society for Horticultural Science 119, 383-388.

Cemeroglu, B., Artik, N., Erbas, S., 1992. Extraction and composition of pomegranate juice. Fluessiges-0bst 59, 335-340.

Chauhan, K.S., Pundir, J.P.S., Singh, S., 1991. Studies on the mineral composition of certain fruits. Haryana Journal of Horticultural Sciences 20, 210-213.

Cohen, A., Goell, A., 1984. Fruit development as an indicator of the irrigation needs of citrus trees. Proceedings International Society Citriculture 1, 114-118.

Cris osto, C.H., Johnson, R.S., Luza, J.G., Crisosto, S.M., 1994. Irrigation regimes affect fruit soluble solids concentration and rate of water loss of ' 0 'Henry' peaches. HortScience 29, 1169-1171.

Domingo, R., Ruiz-Sánchez, M.C., Sánchez-Blanco, M.J., Torrecillas, A., 1996. Water relations, growth and yield of Fino lemon trees under regulated deficit irrigation. Irrigation Science 16, 115-123.

Egea, I., Sanchez-Bel, P., Romojaro, F., Pretel, M.T., 2010. Six edible wild fruits as potential antioxidant additives or nutritional supplements. Plant Foods for Human Nutrition $65,121-129$

Egea, M.I., Sánchez-Bel, P., Martínez-Madrid, M.C., Flores, F.B., Romojaro, F., 2007 The effect of beta ionization on the antioxidant potential of 'Búlida' apricot and its relationship with quality. Postharvest Biology and Technology 46, 63-70.

Fadavi, A., Barzegar, M., Azizi, M.H., Bayat, M., 2005. Physiochemical composition of ten pomegranate cultivars (Punica granatum L.) grown in Iran. Food Science and Technology International 11, 113-119.

Gil, M.I., Cherif, J.,Ayed, N.,Artés, F., Tomás-Barberán, F.A., 1995. Influence of cultivar maturity stage and geographical location on the juice pigmentation of Tunisian pomegranates. Zeitschrift Fur Lebensmittel-Untersuchung Und-Forschung 201 361-364.

Gil, M.I., Sánchez, R., Marín, J., Artés, F., 1996. Quality changes in pomegranate during ripening and cold storage. Zeitschrift Fur Lebensmittel-Untersuchung Und-Forschung 202, 481-485.

Giusti, M.M., Rodriguez-Saona, LE., Wrolstad, R.E., 1999. Molar absorptivity ans color characterisque of acylated and non-acylated pelargodine-based anthocyanins. Journal of Agricultural and Food Chemistry 47, 4631-4637.

Gobbo-Neto, L, Lopes, N.P., 2007. Plantas medicinais: factores de influencia no conteúdo de metabólitos secundários. Quimica Nova 30,374-381.

teúdo de metabólitos secundários. Quimica Nova 30, 374-381. anthocyanins during ripening of new selected pomegranate (Punica granatum) anthocyanins during ripening of new selected pomegranate (
clones. European Food Research and Technology 210, 39-42.

Holland, D., Hatib, K., Bar-Yàakov, I., 2009. Pomegranate: Botany, horticulture, breeding. Horticultural Reviews 35, 127-191.

Horner, J.D., 1990. Nonlinear effects of water deficits on foliar tannin concentration. Biochemical Systematics and Ecology 18, 211-213.

Intrigliolo, D.S., Nicolás, E., Bonet, L., Ferrer, P., Alarcón, J.J., Bartual, J., 2011. Water relations of field grown Pomegranate trees (Punica granatum) under different drip irrigation regimes. Agricultural Water Management 98, 691-696.

Katz, S.R., Newman, R.A., Lansky, E.P., 2007. Punica granatum: heuristic treatment for diabetes mellitus. Journal of Medicinal Food 10,213-217.

Kulkami, A.P., Aradhya, S.M., 2005. Chemical changes and antioxidant activity in pomegranate arils during fruit development. Food Chemistry 93 319-324.

Langley, P., 2000. Why a pomegranate? British Medical Journal 321, $1153-1154$

Lansky, E.P., Newman, R.A., 2007. Punica granatum (pomegranate) and its potential for prevention and treatment of inflammation and cancer. Journal of Ethnopharmacology 109, 177-206

Mattson, W.J., Haack, R.A., 1987. The role of drought in outbreaks of plant-eating insects. BioScience 37, 110-118.

Melgarejo, P., Martínez-Valero, R., Guillamón, J.M., Miró, M., Amorós, A., 1997. Phenological stages of the pomegranate tree (Punicagranatum L.). Annals of Applied Biology $130,135-140$.

Melgarejo, P., Salazar, D.M., Artés, F., 2000. Organics acids and sugar composition of harvested pomegranate fruits. European Food Research and Technology 211 185-190.

Michel, D.S., Melanie, E.R.N., Gerdi, W., Jennifer, J.D., Mailine, H.C., Ruth, M., Caren, J. Raisin, R.N., Dean, O., 2005. Effect of pomegranate juice consumption on mycocardial perfusion in patient with coronary heart disease. American Journal of Cardiology 96, 810-814

Mills, T.M., Behboudian, M.H., Clothier, B.E., 1996. Water relations, growth, and the composition of 'Braeburn' apple fruit under deficit irrigation. Journal of the American Society for Horticultural Science 21, 286-291.

Ortuño, M.F., García-Orellana, Y., Conejero, W., Ruiz-Sánchez, M.C., Alarcón, J.J., Torrecillas, A., 2006. Stem and leaf water potentials, gas exchange, sap flow and trunk diameter fluctuations for detecting water stress in lemon trees. Trees 20 $1-8$.

Ozgen, M., Durgaç, C., Serçe, S., Kaya, C., 2008. Chemical and antioxidant properties of pomegranate cultivars grown in the Mediterranean region of Turkey. Food Chemistry $111,703-706$.

Prasad, R.N., Bankar, G.J., Vashishtha, B.B., 2003. Effect of drip irrigation on growth, yield and quality of pomegranate in arid region. Indian Journal of Horticulture

Ruiz-Sánchez, M.C., Domingo, R., Savé, R., Biel, C., Torrecillas, A., 1997. Effects of water stress and rewatering on leaf water relations of lemon plants. Biologia Plantarum 39, 623-631. 
Shaliendra, A., Narendra, A., 2005. The effect of trickle irrigation on growth, yield and quality of pomegranate (Punica granatum) cv. Ganesh in Chhattisgarh region. Mysore Journal of Agricultural Sciences 39, 175-181.

Singleton, V.L., Orthorfer, R., Lamuela-Raventos, R.M., 1999. Analysis of total phenols and other antioxidant substrates and antioxidants by means of Folin-Ciocalteu reagent. Methods in Enzymology 299, 152-178.

Sonawane, P.C., Desai, U.T., 1989. Performance of staggered cropping in pomegranate. Journal of Maharashtra Agricultural Universities 14, 341-342. SPPS Inc., 2002. SPSS Professional Statistics, vol. 12. Business Intelligence Division, Chicago.

Stover, E., Mercure, E.W., 2007. The Pomegranate: a new look at the fruit of paradise HortScience 42, 1088-1092.

Sulochanamma, B.N., Yellamanda, Reddy, T., Subbi Reddy, G., 2005. Effect of basin and drip irrigation on growth, yield and water use efficiency in pomegranate $\mathrm{cv}$ Gennesh. Acta Horticulturae 696, 277-279.
Torrecillas, A.,Alarcón, J.J., Domingo, R., Planes, J., Sánchez-Blanco, M.J., 1996. Strategies for drought resistance in leaves of two almond cultivars. Plant Science 118 $135-143$.

Torrecillas, A., Domingo, R., Galego, R., Ruiz-Sánchez, M.C., 2000. Apricot tree response to irrigation withholding at different phenological periods. Scientia Horticulturae $85,201-215$.

Torrecillas, A., Guillaume, C., Alarcón, J.J., Ruiz-Sánchez, M.C., 1995. Water relations of two tomato species under water stress and recovery. Plant Science 105 169-176.

Tzulker, R., Glazer, I., Bar-Ilan, I., Holland, D., Aviram, M., Amir, R., 2007. Antioxidant activity, polyphenol content, and related compounds in different fruit juices and homogenates prepared from 29 different pomegranate accessions. Journal of Agricultural and Food Chemistry 55, 9559-9570.

Xiloyannis, C. Massai, R., Dichio, B., 2005. L'acqua e la tecnica dell'irrigazione. In: Fideghelli, C., Sansavini, S. (Eds.), Il Pesco. Edagricole, Bologna, pp. 145-171. 
Research Article

Sustained deficit irrigation affects the colour
and phytochemical characteristics of
pomegranate juice

Pedro Mena, ${ }^{a}$ Alejandro Galindo, ${ }^{b}$ Jacinta Collado-González, a Sara

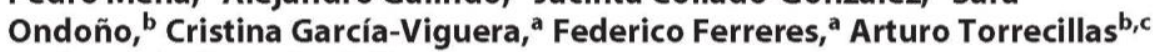
and Angel Gil-Izquierdo ${ }^{\text {a* }}$

\section{Methods}

See pages 85 and 86 .

\section{Results}

No information exists on the consequences of water stress on the pomegranate (Punica granatum L.) tree in terms of the quality and health/nutritional properties of its juice. In this study the influence of two different sustained deficit irrigation treatments on the colour, antioxidant activity and total phenolic compound, total anthocyanin, punicalagin and ellagic acid contents of pomegranate juice was assessed. Control plants were irrigated at 75\% ETo (crop reference vapotranspiration) in order to ensure non-limiting soil water conditions, while others were subjected to sustained deficit irrigation at 43 and $12 \%$ ETo throughout the experimental period. Both moderate (43\%) and severe $(12 \%)$ water stress treatments led to pomegranate juiceswith a more yellowish colour, lower antioxidant activity and lower total phenolic compound, punicalagin and total anthocyanin contents than those from control plants.

\section{Conclusions}

Pomegranate juice from trees under sustained deficit irrigation was of lower quality and less healthful than that from trees without water stress. From a nutritional point of view, this means that a reduction in irrigation provides a dramatic decrease in bioactive phenolic compounds, especially anthocyanins and punicalagin, and consequently a lower visual attraction of the juice owing to the weak red colour of the fruit. 


\title{
Sustained deficit irrigation affects the colour and phytochemical characteristics of pomegranate juice
}

\author{
Pedro Mena, a Alejandro Galindo,b Jacinta Collado-González, a Sara \\ Ondoño, ${ }^{\text {b }}$ Cristina García-Viguera, a Federico Ferreres, ${ }^{\text {a }}$ Arturo Torrecillas ${ }^{\text {b,c }}$ \\ and Angel Gil-Izquierdo ${ }^{\text {a* }}$
}

\begin{abstract}
BACKGROUND: No information exists on the consequences of water stress on the pomegranate (Punica granatum $\mathrm{L}$.) tree in terms of the quality and health/nutritional properties of its juice. In this study the influence of two different sustained deficit irrigation treatments on the colour, antioxidant activity and total phenolic compound, total anthocyanin, punicalagin and ellagic acid contents of pomegranate juice was assessed.

RESULTS: Control plants were irrigated at $75 \% \mathrm{ET}_{0}$ (crop reference evapotranspiration) in order to ensure non-limiting soil water conditions, while others were subjected to sustained deficit irrigation at 43 and $12 \% \mathrm{ET}_{\mathrm{o}}$ throughout the experimental period. Both moderate $(43 \%)$ and severe $(12 \%)$ water stress treatments led to pomegranate juices with a more yellowish colour, lower antioxidant activity and lower total phenolic compound, punicalagin and total anthocyanin contents than those from control plants.

CONCLUSION: Pomegranate juice from trees under sustained deficit irrigation was of lower quality and less healthful than that from trees without water stress. From a nutritional point of view, this means that a reduction in irrigation provides a dramatic decrease in bioactive phenolic compounds, especially anthocyanins and punicalagin, and consequently a lower visual attraction of the juice owing to the weak red colour of the fruit.

(c) 2012 Society of Chemical Industry
\end{abstract}

Keywords: antioxidant capacity; ellagic acid; anthocyanins; phenolic compounds; water stress

\section{INTRODUCTION}

Despite the fact that drought periods have affected $17 \%$ of European territory and $11 \%$ of the population, causing losses of $€ 100$ billion over the last 30 years, ${ }^{1}$ Mediterranean agrosystems must face up to the need to cope with water scarcity, because any policy of continuous expansion of the supply is unsustainable. ${ }^{2}$ As a consequence, an important option for fruit culture in Mediterranean agrosystems could be the use of plant materials characterised as being less water-demanding and more water stress-resistant. Moreover, deficit irrigation must be scheduled in order to allow significant water savings, minimum impact on yield and the profitable production of high-quality fruits.

In this sense, pomegranate (Punica granatum L.) is a very interesting fruit tree, as it possesses drought tolerance characteristics, common in xeromorphic plants, such as high leaf relative apoplastic water content and the ability to confront water stress by developing complementary stress avoidance and stress tolerance mechanisms. ${ }^{3}$ For these reasons, this drought-hardy crop supports heat and thrives well in arid and semiarid areas, even under desert conditions. ${ }^{4,5}$ Additionally, it is known that pomegranate fruits are a source of many valuable compounds such as hydrolysable tannins (punicalagins and punicalins), ${ }_{r}^{6}$ condensed tannins (proanthocyanidins), ${ }^{7}$ anthocyanins ${ }^{8}$ and phenolic acids (gallic acid and ellagic acid). ${ }^{6}$ These compounds, with a major impact on quality parameters and high antioxidant activity, have been linked to a myriad of health promotion features related to oxidative stresses such as cancer, cardiovascular diseases and neurodegeneration. ${ }^{9}$

Regardless of the overriding importance of water shortage in the most suitable regions for pomegranate growth, to the best of our knowledge, the only paper on the effect of deficit irrigation management on yield and fruit characteristics has been that by Mellisho et al, ${ }^{10}$ who established that deficit irrigation induced a decrease in fruit growth, leading to a smaller final fruit

\footnotetext{
* Correspondence to: Angel Gilizquierdo, Food Science and Technology Department, CEBAS-CSIC, PO Box 164, E-30100 Espinardo (Murcia), Spain. E-mail:angelgil@cebas.csic.es

a Research Group on Quality, Safety and Bioactivity of Plant Foods, Food Science and Technology Department, CEBAS-CSIC, PO Box 164, E-30100, Espinardo (Murcia), Spain

b Department ofirigation, CEBAS-CSIC,POBox 164, E-30100, Espinardo (Murcia) Spain

c Unidad Asociada al CSIC de Horticultura Sostenible en Zonas Áridas (UPCTCEBAS), Paseo Alfonso XIII 48, E-30203, Cartagena (Murcia), Spain
} 
size and lower total yield, as well as some changes in colour and chemical characteristics, which reflected earlier ripening. However, no studies have been conducted on the effect of deficit irrigation management on pomegranate juice phenolic compound content. Moreover, according to Horner, ${ }^{11}$ the effect of water stress on phenolic composition is often regarded as inconsistent and very confusing, because it has been reported to cause both increases and decreases in the concentration of various phenolic components.

For these reasons, the present study aimed to look at the effect of different sustained deficit irrigation treatments on the colour, antioxidant activity and phenolic compound, punicalagin and ellagic acid contents of pomegranate juice.

\section{EXPERIMENTAL}

Plant $m$ aterial, experimental conditions and treatments

The experiment was carried out in 2011 on a farm located near the city of Murcia, Spain $\left(37^{\circ} 47^{\prime} \mathrm{N}, 1^{\circ} 25^{\prime} \mathrm{W}\right)$. The plant material consisted of own-rooted adult pomegranate trees ( $P$.granatum $\mathrm{L}$.) $\mathrm{cv}$. Mollar de Elche. Tree spacing followed a $3 \mathrm{~m} \times 5 \mathrm{~m}$ pattern.

The soil of the orchard is Hyposalic Calciorthid moderately saline $\left(5.9 \mathrm{dS} \mathrm{m}^{-1}\right)$ with a silt loam texture, moderate lime content (200 $\mathrm{g} \mathrm{kg}^{-1}$ calcium carbonate), very low organic matter content $\left(11 \mathrm{~g} \mathrm{~kg}^{-1}\right.$ ), low cationic exchange capacity (93.2 meq kg ${ }^{-1}$ ), low available potassium level and high available phosphorus level. The irrigation water used had an electrical conductivity between 0.8 and $1.0 \mathrm{dS} \mathrm{m}^{-1}$. The $\mathrm{Cl}^{-}$concentration in the irrigation water ranged from 59 to $73 \mathrm{mg} \mathrm{L}^{-1}$ during the experimental period. Pest control was that usually used by local growers, and no weeds were allowed to develop within the orchard.

From 11 April (day of the year (DOY) 101) to 14 October (DOY 287), irrigation was carried out daily and during the night by means of a drip irrigation system with one lateral pipe per tree row, using three emitters (each delivering $4 \mathrm{~L} \mathrm{~h}^{-1}$ ) per plant. Three irrigation treatments were considered for measurements. Control plants (treatment T0) were irrigated at 75\% ETo (crop reference evapotranspiration) in order to ensure non-limiting soil water conditions, while T1 and T2 plants were subjected to sustained deficit irrigation at 43 and $12 \%$ ETo respectively throughout the experimental period. In order to apply the same amount of fertilisers to the trees of each treatment, fertigation (fertilisers + water) was applied to the three treatments only during the duration of the irrigation to T2 plants. Before fertigation, TO and T1 plants received only water. Total water amounts applied were 776,448 and $119 \mathrm{~mm}$ for treatments TO, T1 and T2 respectively.

\section{Climate and plant water status}

Micrometeorological data, namely air temperature, solar radiation, air relative humidity, rainfall and wind speed $2 \mathrm{~m}$ above the soil surface, were collected every $15 \mathrm{~min}$ by an automatic weather station located at the farm. Mean daily air vapour pressure deficit $\left(V_{P D}\right)$ was calculated according to Allen et al. ${ }^{12}$ Daily $\mathrm{ET}_{0}$ was calculated using the Penman-Monteith equation. ${ }^{12}$

Midday ( $12 \mathrm{~h}$ solar time) stem water potential $\left(\Psi_{\text {stem }}\right)$ was measured on the south-facing side and the middle third of the trees in two fully developed leaves per tree of each replicate, enclosing the leaves in small black plastic bags covered with aluminium foil for at least $2 \mathrm{~h}$ before measurements in a pressure chamber (Model 3005, Soil Moisture Equipment Co., Santa Barbara, CA, USA), ${ }^{13,14}$

Leaf conductance $\left(g_{1}\right)$ and net photosynthesis $\left(P_{n}\right)$ were measured at midday in two sun-exposed leaves per tree of each replicate using a field portable and closed gas exchange photosynthesis system (LI-6400, LI-COR Inc., Lincoln, NE, USA).

\section{Pomegranate juice samples}

According to market demand, marketable pomegranate fruits from the three irrigation treatments were harvested at fruit ripening phase (14 October, DOY 287). Pomegranate fruits were cut in half and juices of each treatment were obtained by pressure with a laboratory pilot press (Zumonat C-40, Somatic AMD, Valencia, Spain). ${ }^{15}$ Juices were stored frozen $\left(-20^{\circ} \mathrm{C}\right)$ until analysis.

\section{Quality parameters of juices}

$\mathrm{pH}$, titratable acidity (TA) and total soluble solids (TSS) were assessed as quality indices. ${ }^{16}$ Results were expressed as $\mathrm{g}$ anhydrous citric acid $\mathrm{L}^{-1}$ for TA and as ${ }^{\circ}$ Brix for TSS. The ratio TSS/TA, also known as the maturity index (MI), was calculated.

\section{Colour measurement}

Juice colour was determined according to Pérez-Vicente et al. ${ }^{17}$ Samples were measured in glass cells of $2 \mathrm{~mm}$ path length (CTA22) at $520 \mathrm{~nm}$ using a Minolta $C M-508 \mathrm{i}^{\circledR}$ tristimulus colour spectrophotometer (Osaka, Japan) coupled with a CM-A760 transmittance adaptor, illuminant D65 and $10^{\circ}$ observer according to the CIELAB 76 convention. Results were expressed in the CIE $L^{*}, a^{*}, b^{*}$ system, and the mean values of lightness (CIE $\left.L^{*}\right)$, red/greenness (CIE $a^{*}$ ) and blue/yellowness (CIE $b^{*}$ ) parameters for each fruit were calculated. The objective colour was calculated as chromaticity or chroma $\left(C^{*}=\left(a^{* 2}+b^{* 2}\right)^{1 / 2}\right)$ and hue angle $\left(H^{\circ}=\tan ^{-1}\left(b^{*} / a^{*}\right)\right)$.

\section{Identification and quantification of phenolic compounds}

All samples were centrifuged (Model EBA 21, Hettich Zentrifugen, Tuttlingen, Germany) at $10480 \times g$ for 5 min at room temperature. Each supernatant was filtered through a $0.45 \mu \mathrm{m}$ nylon membrane (MS ${ }^{\circledR}$, Membrane Solutions, Plano, TX, USA) before highperformance liquid chromatography (HPLC) analysis on a MerckHitachi liquid chromatograph (Tokyo, Japan), equipped with an L-7455 UV-visible diode array detector, an L-7200 autosampler, an L-7100 pump and a D-7000 interface. Chromatograms were recorded and processed on a Merck-Hitachi D-7000 HSM PC-based chromatography data system. Samples $(20 \mu \mathrm{L})$ were analysed on a Luna $C 18$ column $(25 \mathrm{~cm} \times 0.46 \mathrm{~cm}, 5 \mu \mathrm{m}$ particle size; Phenomenex, Macclesfield, UK) with a security guard (18-ODS $(4 \mathrm{~mm} \times 3 \mathrm{~mm})$ cartridge system (Phenomenex) using a mobile phase of water/formic acid (95:5 v/v) (solvent A) and HPLC-grade methanol (solvent B). Elution was performed at a flow rate of

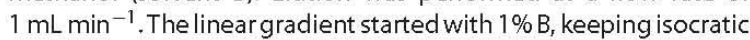
conditions for $5 \mathrm{~min}$, reaching $20 \% \mathrm{~B}$ at $20 \mathrm{~min}, 40 \% \mathrm{~B}$ at $30 \mathrm{~min}$, $95 \% \mathrm{~B}$ at $35 \mathrm{~min}$ and $1 \% \mathrm{~B}$ after $41 \mathrm{~min}$. UV chromatograms were recorded at 360 and $520 \mathrm{~nm}$. Chromatographic comparisons with analytical standards and absorbance spectra were used to identify compounds previously reported, ${ }^{17}$ and they were quantified by the absorbance of their corresponding peaks. Anthocyanins were quantified as cyanidin 3-glucoside (detected at $520 \mathrm{~nm}$ ), and both punicalagin isomers and ellagic acid (free and glucoside) as ellagic acid (at $360 \mathrm{~nm}$ )

Total phenolic compound content (TPC) was determined by the Folin-Ciocalteu method, adapted to microscale by MedinaRemón et al. ${ }^{18}$ with some modifications. Briefly, $15 \mu \mathrm{L}$ aliquots of diluted samples were mixed with $170 \mu \mathrm{L}$ of Milli-Q water 


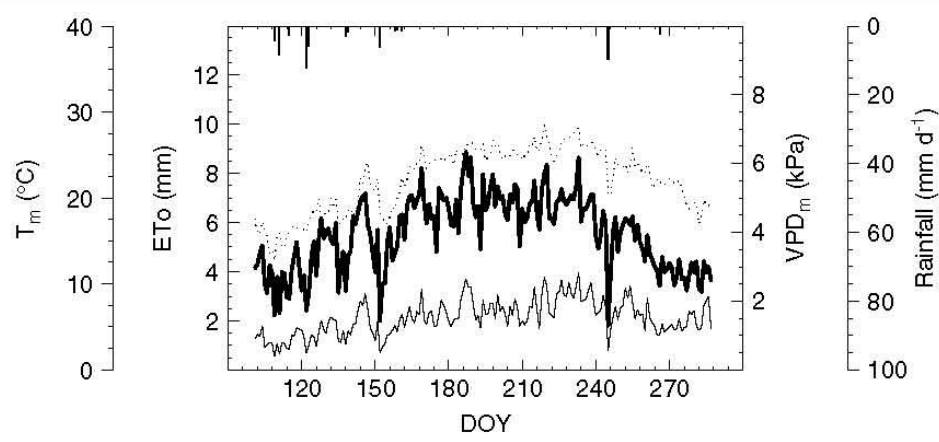

Figure 1. Daily crop reference evapotranspiration (ETo, thick line), mean air temperature $\left(T_{m}\right.$, dotted line), mean air vapour pressure deficit $\left(V P D_{m}\right.$, thin line) and rainfall (vertical bars) during experimental period.

in a 96-well microplate (Nunc, Roskilde, Denmark), then 12 $\mu \mathrm{L}$ of Folin-Ciocalteu reagent and $30 \mu \mathrm{L}$ of sodium carbonate $\left(200 \mathrm{~g} \mathrm{~L}^{-1}\right)$ were added. The mixtures were allowed to stand at room temperature in darkness for $1 \mathrm{~h}$. After the reaction period, 73 $\mu \mathrm{L}$ of Milli-Q water was added and the absorbance at $765 \mathrm{~nm}$ was recorded in an Infinite ${ }^{\circledR}$ M200 microplate reader (Tecan, Grödig, Austria). Samples were quantified using gallic acid as standard and results were expressed as mg gallic acid equivalent (GAE) $L^{-1}$.

\section{ABTS $^{+}$antioxidant capacity}

All samples were centrifuged (Model EBA 21, Hettich Zentrifugen) at $10480 \times g$ for $5 \mathrm{~min}$ at room temperature. The free radicalscavenging activity was determined using the $\mathrm{ABTS}^{+}$free radical method in aqueous media according to Mena et al. ${ }^{15}$ The antioxidant activity was evaluated by measuring the variation in absorbance at $414 \mathrm{~nm}$ after $50 \mathrm{~min}$. Assays were carried out using 96-well microplates (Nunc) and an Infinite ${ }^{\circledR}$ M200 microplate reader (Tecan). All reactions were started by adding $2 \mu \mathrm{L}$ aliquots of the corresponding diluted samples to wells containing $250 \mu \mathrm{L}$ of stock solution. Results were expressed as mmol Trolox $\mathrm{L}^{-1}$.

\section{Statistical design and analysis}

The design of the experiments was completely randomised with four replications, each replication consisting of three adjacent tree rows, each with 13 trees. Measurements were taken on the inner tree of the central row of each replicate, which were very similar in appearance (leaf area, trunk cross-sectional area, height, ground shaded area, etc.), while the other trees served as border trees. Data were analysed using SPSS software (SPPS Inc., Chicago, IL, USA). Analysis of variance was performed and mean values were compared by an $\mathrm{LSD}_{005}$ test. $\Psi_{\text {stem, }} g_{1}$ and $P_{\mathrm{n}}$ values for each replicate were averaged before the mean and standard error (SE) of each treatment were calculated.

\section{RESULTS}

\section{Plant water status}

During the experimental period, average daily maximum and minimum air temperatures were 28.9 and $15.2^{\circ} \mathrm{C}$ respectively, with a mean relative humidity of $60 \%$. VPD $m$ ranged from 0.41 to $2.83 \mathrm{kPa}$, and accumulated $\mathrm{ET}_{\mathrm{o}}$ was $1037 \mathrm{~mm}$ (Fig. 1). Rainfall was very scarce, reaching only $60 \mathrm{~mm}$ and taking place in 13 daily episodes (Fig. 1).

$\Psi_{\text {stem values for plants of the three treatments decreased }}$ gradually from the beginning of the measurement period to
DOY 248 and increased thereafter (Fig. 2A). Minimum $\Psi_{\text {stem }}$ values on DOY 248 were $-1.23,-1.78$ and $-2.62 \mathrm{MPa}$ in T0, T1 and T2 plants respectively. In spite of the observed moderately decreasing tendency of $\Psi_{\text {stem }}$ values in T0 plants, these values were always high, with a mean of $-0.85 \mathrm{MPa}$ during the experimental period. Differences in $\Psi_{\text {stem }}$ values between T0 and T1 plants were lowe than those observed between $\mathrm{T} 0$ and $\mathrm{T} 2$ plants and were significant from DOY 125 and 154 respectively (Fig. 2A).

In TO plants, $g_{1}$ values presented an overall tendency to increase as the season progressed (Fig. 2B). Sustained deficit irrigation caused a reduction in 9 । values in T2 plants from DOY 125 onwards, reflecting an important degree of stomatal regulation during the experimental period. However, deficit irrigation in T1 plants induced $g_{1}$ values very similar to those observed in TO plants, except on DOY 154 and 248 when $g_{1}$ values in T1 plants were significantly lower than those observed in TO plants (Fig. 2B)

$P_{n}$ values in TO plants increased from the beginning of the experiment to DOY 154, varied slightly from then to DOY 248 and decreased from then to the end of the experiment (Fig. $2 \mathrm{C}$ ). T1 plants showed $P_{\mathrm{n}}$ values very similar to those observed in TO plants, except on DOY 248 when $P_{n}$ values in T1 plants were significantly lower than those observed in control plants. In contrast, deficit irrigation in T2 plants induced lower $P_{\mathrm{n}}$ values than those observed in T0 and T1 plants from DOY 125 to the end of the experiment (Fig. 2C).

\section{Quality attributes and colour parameters}

No significant effect of irrigation treatment was observed on TSS, TA and TSS/TA values. In contrast, pomegranate juice from $\mathrm{T} 2$ fruits showed a lower $\mathrm{pH}$ value than the juices from other treatments (Table 1).

A significant effect of water stress on pomegranate juice colour was observed (Table 2 ). Juice from T1 fruits showed similar $L^{*}$ and $a^{*}$ values to T0 juice. However, T2 juice displayed higher $L^{*}$ and lower $a^{*}$ values than T0 juice. Moreover, water stress brought about a progressive increase in $b^{*}$ and $H^{\circ}$ values. Also, the $C^{*}$ value in T1 juice was similar to those in T0 and T2 juices, while the $C^{*}$ value in $\mathrm{T} 2$ juice was higher than that in T0 juice (Table 2)

\section{Phytochemical compounds and antioxidant activity}

Irrigation treatment did not affect the ellagic acid content of pomegranate juice (Table 3 ). However, the anthocyanin contents of TO and T1 juices were similar and higher than that of $\mathrm{T} 2$ juice. Punicalagin content decreased as water stress increased (Table 3 ). 

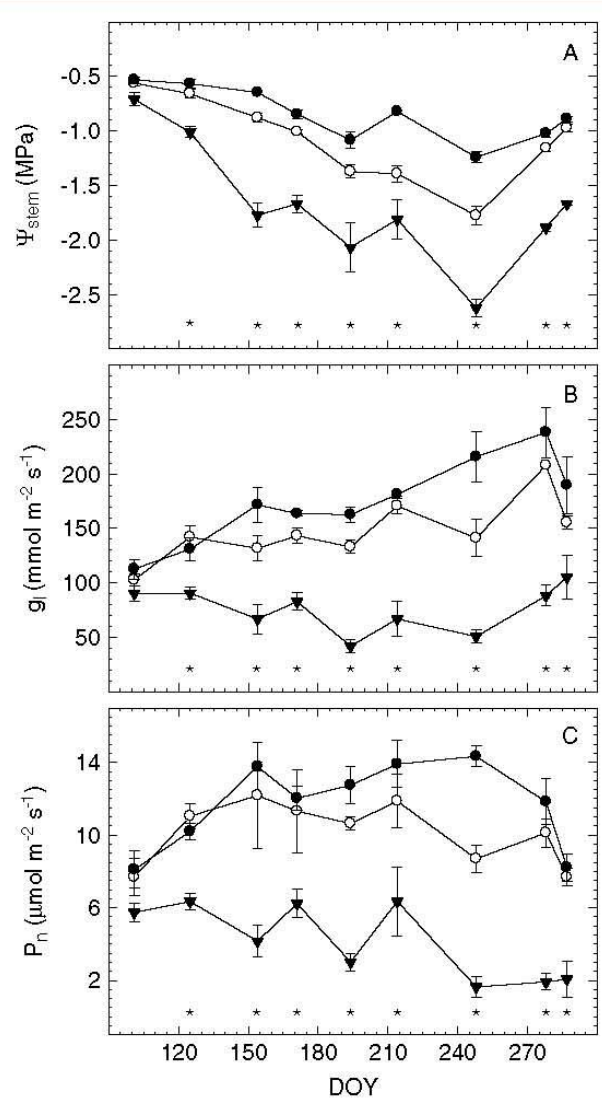

Figure 2. Midday (A) stem water potential ( $\left.\Psi_{\text {stem }}\right)$, (B) leaf conductance $\left(g_{1}\right)$ and $(C)$ net photosynthesis $\left(P_{n}\right)$ values (mean $\pm \mathrm{SE}$, not shown when smaller than symbols) for pomegranate plants in T0 (•), T1 (O) and T2 (v) treatments during experimental period. Asterisks indicate significant differences between treatments $(P \leq 0.05)$.

Table 1. Effect of irrigation treatments on pomegranate juice total soluble solids (TSS, ${ }^{\circ}$ Brix), titrable acidity (TA, $\mathrm{g}$ anhydrous citric acid $\left.\mathrm{L}^{-1}\right), \mathrm{pH}$ and maturity index (TSS/TA)

\begin{tabular}{|lllll|} 
Treatment & TSS & TA & $p H$ & TSS/TA \\
\hline T0 & $16.8 \mathrm{a}$ & $2.5 \mathrm{a}$ & $4.1 \mathrm{a}$ & $6.72 \mathrm{a}$ \\
T1 & $17.5 \mathrm{a}$ & $2.4 \mathrm{a}$ & $4.1 \mathrm{a}$ & $7.29 \mathrm{a}$ \\
T2 & $17.5 \mathrm{a}$ & $2.3 \mathrm{a}$ & $3.8 \mathrm{~b}$ & $7.60 \mathrm{a}$ \\
\hline
\end{tabular}

Means within a column that do not have a common letter are significantly different by $\mathrm{LSD}_{0.05}$ test.

TPC decreased under water stress, with similar contents being found in T1 and T2 juices (Table 3). Water stress also decreased $\mathrm{ABTS}^{+}$values, with $\mathrm{T} 1$ and $\mathrm{T} 2$ juices showing similar values (Table 3 ).

\section{DISCUSSION}

The fact that plant water relations in TO plants were characterised by high $\Psi_{\text {stem }}$ values, which only decreased slightly during the experimental period, and that gas exchange $\left(g_{1}\right.$ and $\left.P_{n}\right)$ progressively increased towards very high values (Fig. 2) suggests

\begin{tabular}{|c|c|c|c|c|c|}
\hline Treatment & $L^{*}$ & $a^{*}$ & $b^{*}$ & $C^{*}$ & $H^{\circ}$ \\
\hline TO & $9.8 \mathrm{~b}$ & $28.4 a$ & $16.7 \mathrm{C}$ & $33.0 \mathrm{~b}$ & $30.3 c$ \\
\hline T1 & $14.1 \mathrm{~b}$ & $27.1 \mathrm{a}$ & $24.2 b$ & $36.5 a b$ & $41.6 \mathrm{~b}$ \\
\hline T2 & 23.3a & $13.9 b$ & $37.6 \mathrm{a}$ & $40.1 \mathrm{a}$ & $69.6 \mathrm{a}$ \\
\hline
\end{tabular}

Means within a column that do not have a common letter are significantly different by $\mathrm{LSD}_{0.05}$ test

\begin{tabular}{|c|c|c|c|c|c|}
\hline Treatment & TAC & Punicalagin & Ellagic acid & TPC & $\mathrm{ABTS}^{+}$ \\
\hline T0 & $70.7 a$ & $241.2 \mathrm{a}$ & $50.0 \mathrm{a}$ & $3554.9 \mathrm{a}$ & $42.14 a$ \\
\hline T1 & $78.0 \mathrm{a}$ & $154.3 b$ & $41.5 \mathrm{a}$ & 1938.7b & $31.07 \mathrm{~b}$ \\
\hline $\mathrm{T} 2$ & $17.6 b$ & $65.2 \mathrm{C}$ & $45.5 a$ & $2140.1 b$ & $32.49 b$ \\
\hline
\end{tabular}

Means within a column that do not have a common letter are significantly different by $\mathrm{LSD}_{0.05}$ test.

that irrigation water requirements in control pomegranate plants were attained. Moreover, the non-appearance of plant symptoms and the fact that water relations under flooding conditions are characterised by a similar behaviour to those observed under water stress, due to chemical signals from roots and an increase in the resistance to water flowing through the plant, ${ }^{19,20}$ confirmed that control plants never became waterlogged.

The rate of development of water stress in T1 and T2 plants was very low, because $\Psi_{\text {stem }}$ values decreased by only around 0.008 and $0.013 \mathrm{MPa}$ day $^{-1}$ respectively (Fig. 2)..$^{21}$ The fact that TO and T1 plants showed minor differences in $\Psi_{\text {stem }}$ values and that differences in gas exchange values were only occasionally significant (Fig. 2) indicated that sustained deficit irrigation in T1 plants induced a moderate water stress level. In contrast, the important differences observed in $\Psi_{\text {stem }}$ values for T0 and T2 plants and the degree of stomatal regulation observed in T2 plants (Fig. 2) showed that sustained deficit irrigation in these plants induced a severe water stress level during the experimental period.

Water stress did not affect the basic quality parameters of the pomegranate juice except for $\mathrm{pH}$, where only a slight but significant reduction was found under severe water stress (T2) (Table 1). Taking into account only these parameters, $T 1$ and $T 2$ pomegranate juices did not reflect earlier ripening by the water stress achieved in the experiment as could be expected owing to the effect of water shortage on the morphological quality of pomegranate fruits. ${ }^{10}$

The changes in $b^{*}$ and $H^{\circ}$ values of T1 juice along with the changes in all colour parameters of T2 juice indicated that pomegranate fruits under moderate water stress ( $T 1$ ) yielded juice with more yellowness, while fruits under severe water stress ( $\mathrm{T} 2)$ produced juice that was completely distinct and far from the effective colour of pomegranate juice. Besides, T2 juice showed not only more yellowish colour than $\mathrm{T} 1$ juice but also less intense red colour and higher luminosity. These results were in agreement with the decrease in anthocyanin content observed in the juice of pomegranate fruits under severe water stress (T2) (Table 3 ). 
In this sense, Schwartz et al.22 reported that pomegranate fruits from desert areas exhibited lower levels of total anthocyanins in both the peel and arils compared with fruits grown under Mediterranean conditions. Gil et al. ${ }^{23}$ showed that fruits oriented directly to the sunlight accumulated more anthocyanins in their peel than fruits located on the inner branches, because UV light is one of the factors affecting the biosynthesis of anthocyanins. For these reasons, and taking into consideration that temperature and sunlight incidence is higher under desert conditions than under Mediterranean conditions, Schwartz et al. ${ }^{22}$ assumed that the decrease in peel and aril anthocyanin contents under desert conditions was due to temperature. Bearing in mind that in our experiment the pomegranate trees from the three irrigation treatments were under identical climatic conditions, as well as the decrease in anthocyanin content in $\mathrm{T} 2$ juice due to deficit irrigation (Table 3), water stress could be suggested as another factor controlling anthocyanin biosynthesis.

The fact that anthocyanin content, TPC and antioxidant activity decreased in T2 juice whereas only TPC and antioxidant activity decreased in $\mathrm{T} 1$ juice (Table 3 ) suggests that phenolics other than anthocyanins may be the major contributors to pomegranate juice antioxidant activity. In agreement with our results, Tzulker et al. ${ }^{24}$ indicated that punicalagin contributed significantly to the antioxidant activity in pomegranate juice. Nevertheless, taking into account that a decrease in punicalagin concentration was observed but no change in ellagic acid (punicalagin hydrolysed compound ${ }^{6}$ ) concentration, this could indicate that moderate (T1) and severe (T2) water stress levels inhibit punicalagin biosynthesis.

It is well known that water stress influences the content of secondary metabolites in plant tissues. However, the effects of water deficit on phenolic composition are not clear. Actually, some authors have suggested that it is not possible to establish a linear correlation between water stress and phenolic contents. ${ }^{25,26}$ For example, Chaves et al. ${ }^{27}$ reported an important accumulation of anthocyanins in grapes under water stress. In contrast, Kennedy et al..$^{28,29}$ showed that osmotic stress had little or no effect on anthocyanin accumulation in grape berries. This confusing relation between water stress and phenolic production could be ascribed to the fact that only a few papers on this topic have reported quantitative measures of water stress, its rate of development and duration, the phenological period of stress imposition and other aspects essential for the characterisation of experimental water stress conditions.

Taking into account that plant growth begins to decrease at a water potential higher than that at which stomatal closure takes place, ${ }^{30}$ Horner ${ }^{11}$ proposed a model to predict the concentration of phenolic compounds as a function of water status. The quadratic relationship between the two variables is based on the hypothesis that, under mild water stress, $\mathrm{CO}_{2}$ assimilation could be maintained and carbon-based secondary metabolites should increase when carbohydrates exceed the amount required for growth. Thus mild osmotic stress may lead to a reduction in plant growth, with increasing concentration of non-nitrogenous secondary metabolites. When water stress increases, stomatal regulation takes place and $\mathrm{CO}_{2}$ assimilation is reduced. In this situation, carbon should be preferentially allocated to the synthesis of primary metabolites to the detriment of the synthesis of secondary metabolites.

\section{CONCLUSIONS}

Pomegranate juices from trees grown under moderate and severe sustained deficit irrigation are of lower quality and less rich in bioactive compounds than those from trees grown without water stress. From a nutritional point of view, this means that a reduction in irrigation provides a dramatic decrease in levels of phenolic compounds, especially anthocyanins and punicalagins, and hence a lower visual attraction of the resulting fruit juice owing to its weak red colour.

\section{ACKNOWLEDGEMENTS}

The authors are grateful to the Projects AGL2010-19201-C0401AGR (CICYT/FEDER), AGL 2011-23690 (CICYT), CSD $007-0063$ (CONSOLIDER-INGENIO 2010'FUN-C-FOOD') and CSIC 201170E041 (Spanish Ministry of Economy and Competitiveness) and to the Fundación Séneca (04486/GERM/06) and the lberoamerican Programme for Science, Technology and Development (CYTED)Action 112RT0460 CORNUCOPIA. P Mena and A Galindo were funded by a grant of the FPU Fellowship Programme from the Spanish Ministry of Education.

\section{REFERENCES}

1 Collins R, Kristensen P and Thyssen N, Water resources across Europe - confronting water scarcity and drought. EEA Report No. 2/2009, European Environment Agency, Copenhagen (2009).

2 Pereira LS, Cordery I and lacovides I, Coping with water scarcity. IHPV/ Technical Documents in Hydrology No. 58, UNESCO, Paris (2002).

3 Rodríguez $\mathrm{P}$, Mellisho $\mathrm{CD}$, Conejero W, Cruz ZN, Ortuño MF, Galindo $A$, et al, Plant water relations of leaves of pomegranate trees unde different irrigation conditions. Environ Exp Bot 77:19-24 (2012).

4 Aseri GK, Jain N, Panwar J, Rao AV and Meghwal PR, Biofertilizers improve plant growth, fruit yield, nutrition, metabolism and rhizosphere enzyme activities of pomegranate (Punica granatum L.) in Indian Thar Desert. Sci Hort 117:130-135 (2008).

5 Sarkhosh A, Zamani Z, Fatahi R and Ebadi A, RAPD markers revea polymorphismamong some Iranian pomegranate(Punicagranatum L) genotypes. Sci Hort 111:24-29 (2006).

6 Gil MI, Tomás-Barberán FA, Hess-Pierce B, Holcroft DM and Kader AA, Antioxidant activity of pomegranate juice and its relationship with phenolic composition and processing. I Agric Food Chem 48:4581-4589(2000)

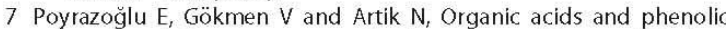
compounds in pomegranates (Punica granatum L.) grown in Turkey. J Food Compos Anal 15:567-575 (2002).

8 Hernández F, Melgarejo P, Tomás-Barberán FA and Artés F, Evolution of juice anthocyanins during ripening of new selected pomegranate (Punica granatum) clones. Eur Food Res Technol 210:39-42 (1999).

9 Mena $P$, Gironés-Vilaplana $A$, Moreno DA and García-Viguera $C$, Pomegranate fruit for health promotion: myths and realities, in Antioxidant Properties of Crops III, ed. by Jiménez A and GarcíaViguera C. Functional Plant Science and Biotechnology 5 (Special Issue 2), pp. 33-42 (2011)

10 Mellisho CD, Egea I, Galindo A, Rodríguez P, Rodríguez J, Conejero W et al, Pomegranate (Punica granatum L.) fruit response to different deficit irrigation conditions. Agric Water Manag 114:30-36 (2012).

11 Horner JD, Nonlinear effects of water deficits on foliar tannin concentration. Biochem Syst Ecol 18:211-213 (1990).

12 Allen RG, Pereira LS, Raes D and Smith $M$, Crop evapotranspiration (guidelines for computing crop water requirements). FAO irrigation and Drainage Paper 56 (1998).

13 Fulton A, Buchner R, Olson B, Schwankl L, Gilles C, Bertagna N et al, Rapid equilibration of leaf and stem water potential under field conditions in almonds, walnuts, and prunes. HortTechnology 11:609-615(2001).

14 Shackel K, A plant-based approach to deficit irrigation in trees and vines. HortScience 46:173-177 (2011).

15 Mena P, García-Viquera C, Navarro-Rico J, Moreno DA, Bartual J, Saura $\mathrm{D}$, et al, Phytochemical characterisation for industrial use of 
pomegranate (Punica granatum L.) cultivars grown in Spain. $j \mathrm{SC}$ FoodAgric 91:1893-1906 (2011).

16 González-Molina E, Moreno DA and García-Viguera C, A new drink rich in healthy bioactives combining lemon and pomegranate juices. Food Chem 115:1364-1372 (2009)

17 Pérez-Vicente A, Serrano P, Abellán P and García-Viguera C, Influence of packaging material on pomegranate juice colour and bioactive compounds, during storage. I Sci Food Agric 84:639-644 (2004).

18 Medina-Remón A, Barrionuevo-González A, Zamora-Ros R, Andres Lacueva C, Estruch R, Martínez-González MA, et al, Rapid Folin-Ciocalteu method using microtiter 96 -well platecartridges for solid phase extraction to assess urinary total phenolic compounds, as a biomarker of total polyphenols intake. Anal Chim Acta 634:54-60 (2009)

19 Ortuño MF, Alarcón JJ, Nicolás E and Torrecillas A, Water status indicators of lemon trees in response to flooding and recovery. Bio Plantanum 51:292-296 (2007).

20 Ruiz-Sánchez MC, Domingo R, Morales D and Torrecillas A, Water relations of Fino lemon plants on two rootstocks under flooded conditions. Plant Sci 120:119-125 (1996)

21 Hale MG and Orcutt DM, The Physiology of Plants under Stress. Wiley, New York, NY (1987).

22 Schwartz E Tzulker R, Glazer I, Bar-Ya'akov I Wlesman Z, Tripler E, et al, Environmental conditions affect the color, taste, and antioxidant capacity of 11 pomegranate accessions' fruits. I Agric Food Chem 57:9197-9209 (2009).

23 Gil MI, Cherif J, Ayed N, Artés F and Tomás-Barberán FA, Influence of cultivar, maturity stage and geographical location on the juice pigmentation of Tunisian pomegranates. Z Lebensm Unters Forsch 201:361-364(1995).

24 Tzulker R, Glazer I, Bar-llan I, Holland D, Aviram M and Amir Antioxidant activity, polyphenol content, and related compounds in different fruit juices and homogenates prepared from 29 different pomegranate accessions. J Agric Food Chem 55:9559-9570 (2007).

25 Gobbo-Neto L and Lopes NP. Medicinal plants: factors of influence on the content of secondary metabolites. Quim Nova 30:374-381 (2007).

26 Mattson WJ and Haack RA, The role of drought stress in provoking outbreaks of phytophagous insects, in Insect Outbreaks, ed. by Barbosa P and Schultz JC. Academic Press, San Diego, CA, pp. 365-407 (1987).

27 Chaves MM, Santos TP, Souza CR, Ortuño MF, Rodrigues ML, Lopes CM, et al, Deficit irrigation in grapevine improves water-use efficiency while controlling vigour and production quality. Ann App/ Bio 150:237-252 (2007)

28 Kennedy JA, Matthew/ MA and Waterhouse AL, Changes in grape seed polyphenols during fruit ripening. Phytochemistry 55:77-85(2000).

29 Kennedy JA, Matthews MA and Waterhouse AL, Effect of maturity and vine water status on grape skin and wine flavonoids. Am J Enol Viti 53:268-274 (2002)

$30 \mathrm{Hsiao}$ TC, Acevedo E, FereresE and Henderson DW Waterstress, growth and osmotic adjustment. Philos Trans R Soc Lond B 273:479-500 (1976) 


\title{
Phytochemical and quality attributes of pomegranate fruits for juice consumption as affected by ripening stage and deficit irrigation
}

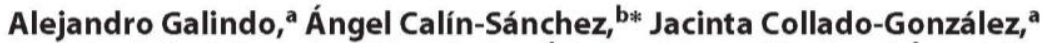 \\ Sara Ondoño, ${ }^{\mathrm{C}}$ Francisca Hernández, ${ }^{\mathrm{d}}$ Arturo Torrecillas ${ }^{\mathrm{a}}$ and Ángel A \\ Carbonell-Barrachinab

\section{Methods}

See pages 92 and 93.

\section{Results}

Pomegranate $(P G)$ is a drought resistant crop, thriving well with scarce water resources. The non-climateric character of $P G$ remarks the importance of determining the optimum harvest time to improve quality and phytochemical properties of PG. The influence of two different irrigation treatments on physicochemical and phytochemical parameters of PG was assessed. Control trees (T0) were over irrigated (105\% ETo). From the beginning of the second half of rapid fruit growth period to the last harvest, T1 plants were subjected to sustained deficit irrigation (33\% ETo). Results indicated that T1 fruits exhibited a darker and more intense garnet colour than T0 fruits, but deficit irrigation led to a significant decrease in total fruit yield and number of total fruits per tree. T1 fruits showed similar bioactive quality than T0 fruits; however, T1 fruits advanced the optimal harvest time by about 7-8 days with respect to T0 fruits.

\section{Conclusions}

Late-pomegranate fruits were rich in phytochemicals and could be of great interest to the juice industry. Knowledge of these trends is important, especially to improve PG juice quality and to contribute to the sustainability of PG culture with respect to water, fertiliser and energy saving. 


\title{
Phytochemical and quality attributes of pomegranate fruits for juice consumption as affected by ripening stage and deficit irrigation
}

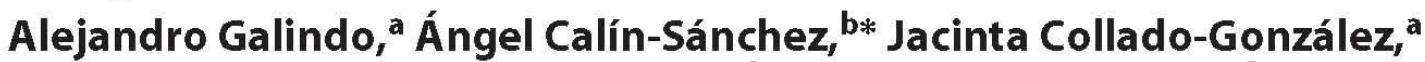 \\ Sara Ondoño, ${ }^{\mathrm{C}}$ Francisca Hernández, ${ }^{\mathrm{d}}$ Arturo Torrecillas ${ }^{\mathrm{a}}$ and Ángel A \\ Carbonell-Barrachina ${ }^{\text {b }}$
}

\begin{abstract}
BACKGROUND: Pomegranate (PG) is a drought resistant crop, thriving well with scarce water resources. The non-climateric character of PG remarks the importance of determining the optimum harvest time to improve quality and phytochemical properties of PG.

RESULTS: The influence of two different irrigation treatments on physico-chemical and phytochemical parameters of PG was assessed. Control trees (T0) were over irrigated (105\% ETo). From the beginning of the second half of rapid fruit growth period to the last harvest, T1 plants were subjected to sustained deficit irrigation (33\% ETo). Results indicated that T1 fruits exhibited a darker and more intense garnet colour than T0 fruits, but deficit irrigation led to a significant decrease in total fruit yield and number of total fruits per tree. T1 fruits showed similar bioactive quality than T0 fruits; however, T1 fruits advanced the optimal harvest time by about $7-8$ days with respect to T0 fruits.
\end{abstract}

CONCLUSIONS: Late-pomegranate fruits were rich in phytochemicals and could be of great interest to the juice industry. Knowledge of these trends is important, especially to improve PG juice quality and to contribute to the sustainability of PG culture with respect to water, fertiliser and energy saving.

(c) 2013 Society of Chemical Industry

Keywords: antioxidant capacity; anthocyanins; harvest time; midday stem water potential; polyphenols; Punica granatum

\section{INTRODUCTION}

Although pomegranate (PG) (Punica granatum L.) has frequently been considered a minor fruit crop, it is regarded as a very interesting fruit tree for farmers in many areas around the world. This is especially true in areas of poor soils where this tree is able to adapt without significantly reducing its yield. ${ }^{1}$ Moreover, its fruits are large berries with an edible portion that has been extensively used in medicine by many traditional cultures, being recommended (1) as a preventive treatment for coronary heart disease, ${ }^{2}(2)$ to improve the chemotherapeutic effects on human prostate cancer, ${ }^{3}(3)$ to significantly reduce blood pressure, ${ }^{4}$ and (4) to improve induced-stress of myocardial ischaemia in patients with coronary artery disease. ${ }^{5}$

Pomegranate farming is mainly confined to semi-arid, mildtemperate to subtropical climates. Commercial orchards of PG trees can now be found in many regions of the world, particularly in the Mediterranean Basin, where high quality fruits are obtained. ${ }^{6,7}$ In this sense, Spain, as a Mediterranean country, is the main European PG producer and its production is mainly more than $90 \%$, located in the province of Alicante, followed by the Murcia Region and Andalucía. ${ }^{8}$

Pomegranate presents drought resistance characteristics, common in xeromorphic plants, such as high leaf relative apoplastic water content, and ability to confront water stress by developing complementary stress avoidance and stress tolerance mechanisms. ${ }^{9}$ For these reasons, this drought-hardy crop supports heat and thrives well in arid and semi-arid areas, even under desert conditions. ${ }^{10,11}$

In spite of the paramount importance of water shortage in the most suitable regions for the PG growth almost not reports exist

* Correspondence to: Ángel Calín-Sánchez, Miguel Hernández University, Department of Agroofood Technology, Food Quality and Safety Research Group, Carretera de Beniel, km 3.2, 03312-Orihuela, Alicante, Spain. E-mail: acalin@umh.es

a Department ofirrigation, CEBAS-CSIC, P.O. Box 164, E-30100 Espinardo, Murcia, Spain

b Miquel Hermández University, Department of Agroofood Technology, Food Quality andSafety Research Group, Carretera de Beniel, $\mathrm{km}$ 3,2.03312-Orihuel a, Alicante, Spain

c Department of Soil andWater Conservation, CEBAS-CSIC, P.O. Box 164, E-30100 Espinardo, Murcia, Spain

d Miguel Hernández University, Department of Plant Sciences andMicrobiology, Carretera de Beniel, km 3,2.03312-Orihuela, Alicante, Spain 
on the effect of irrigation on PG fruit yield and quality. Recently, Mellisho et al. ${ }^{12}$ established that deficit irrigation induces a lower final fruit size and lower total yield, and some changes which reflected earlier fruit ripening. Moreover, Mena et al..$^{13}$ showed that sustained deficit irrigation provides a dramatic decrease in PG bioactive phenolic compounds, especially anthocyanins and punicalagin, and a lower visual attraction of the juice owing to a weaker red colour of the fruit. These results can be considered as key for PG culture in areas with limited water resources because the acceptance of PG products among consumers depends on the health benefits of the fruit ${ }^{14}$ and its organoleptic properties (e.g. attractive appearance and colour). ${ }^{15}$

Pomegranate is a non-climateric fruit, which should be harvested when fully ripe. If it is harvested before full-ripening, fruits will not have full flavour and the red colour of the arils will be of lower intensity; if it is harvested after full-ripening, fruits will be too soft, the flavour will be flat due to inappropriate equilibrium among sugars and organic acids, and cracking of fruits will be intense.

For all the above reasons, the main aim of the current study was to establish whether deficit irrigation will be useful in advancing the ripening of pomegranate fruits. In this way, deficit irrigation would be useful in saving irrigation water and having an early harvest of fruits. To reach this general aim, the main quality and phytochemical attributes of pomegranate fruits and juice were evaluated in order to determine the proper harvest time.

\section{MATERIALS AND METHODS} Samples and experimental design

The experiment was carried out in 2010 in a farm located in Alhama de Murcia (Spain) $\left(37^{\circ} 47^{\prime} \mathrm{N}, 1^{\circ} 25^{\prime} \mathrm{W}\right)$. The plant material consisted of own rooted adult PG trees (Punica granatum L.) cV. Mollar de Elche. Trees were spaced following a $3 \mathrm{~m} \times 5 \mathrm{~m}$ pattern, and showed an average trunk diameter of about $17 \mathrm{~cm}$ and an average ground cover of about $68 \%$.

The soil of the orchard is a hyposalic calciorthid moderately saline $\left(5.9 \mathrm{dS} \mathrm{m}^{-1}\right)$, with a silt loam texture, moderate lime content (20\% calcium carbonate), very low organic matter content $(1.1 \%)$, low cationic exchange capacity $\left(9.32 \mathrm{Meq} 100 \mathrm{~g}^{-1}\right)$, low available potassium and high available phosphorus levels. The irrigation water used had an electrical conductivity between 0.8 and $1.0 \mathrm{dS}$ $\mathrm{m}^{-1}$. The $\mathrm{Cl}^{-}$concentration in the irrigation water ranged from 62 to $70 \mathrm{mg} \mathrm{L}^{-1}$ during the experimental period.

Irrigation was carried out daily and during the night using a drip irrigation system with one lateral pipe per tree row and three emitters (each delivering $4 \mathrm{~L} \mathrm{~h}^{-1}$ ) per plant. Control plants (treatment T0) were over-irrigated (105\% ETo) in order to guarantee non-limiting soil water conditions. From 29 July [day of the year (DOY) 210] to 17 November (DOY 321) - that is, from the beginning of the second half of rapid fruit growth period to the last harvest (beginning of leaf senescence) - T1 plants were subjected to sustained deficit irrigation throughout the experimental period, irrigating at $33 \%$ ETo. In order to apply the same amount of fertilisers to the trees of each treatment, fertigation was applied to both treatments only during the duration of the irrigation to T1 plants. Before fertigation, T0 plants received only water. Total water amounts applied during the measurements period were 474 and $149 \mathrm{~mm}$ for T0 and T1 treatments, respectively. Pest control and fertilisation practices were those usually used by local growers, and no weeds were allowed to develop within the orchard.

\section{Clim ate and plant water status}

Meteorological data, namely air temperature, solar radiation, air relative humidity, rainfall, and wind speed $2 \mathrm{~m}$ above the soil surface, were collected every $15 \mathrm{~min}$ by an automatic weather stations located in the farm. Mean daily air vapour pressure deficit $\left(\mathrm{VPD}_{\mathrm{m}}\right.$ ) was calculated according to Allen et al. ${ }^{16}$ Daily ETo was estimated using the Penman-Monteith Equation. ${ }^{16}$

Midday ( $12 \mathrm{~h}$ solar time) stem water potential $\left(\Psi_{\text {stem }}\right)$ was measured on the south facing side and the middle third of the trees, in two fully developed leaves per tree of each replicate, enclosing leaves in small black plastic bags covered with aluminium foil for at least $2 \mathrm{~h}$ before measurements in the pressure chamber (model 3005; Soil Moisture Equipment Co., Santa Barbara, CA, USA).

Midday leaf conductance and net photosynthesis were measured in two sun-exposed leaves per tree of each replicate, using a field portable and closed gas exchange photosynthesis system (LI-6400; LICOR Inc., Lincoln, NE, USA) in a similar number and type of leaves as used for the $\Psi_{\text {stem }}$ measurements.

\section{Physico-chemical analysis}

Fruit growth and yield

In order to study the changes of PG fruit characteristic from the last part of rapid fruit growth to the beginning of leaf senescence, fruit samples from both irrigation treatments were picked on eight occasions (picking times): 24 August (DOY 236), 8 September (DOY 252), 21 September (DOY 264), 14 October (DOY 287), 22 October (DOY 295), 28 October (DOY 301), 3 November (DOY 307) and 11 November (315).

PG fruit yield was assessed, according to market demand, on three occasions (harvest times): 14 October (DOY 287), 22 October (DOY 295) and 3 November (DOY 307).

Ten fruits per replicate at each harvest time were weighed and sized. Then, the fruits were peeled by hand and the arils were weighed, homogenised and squeezed, in two-layered muslin cloth, to extract the complete juice. The juice was centrifuged $(1200 \times g)$ at $4^{\circ} \mathrm{C}$ and stored at $-70^{\circ} \mathrm{C}$ until chemical analyses were conducted.

\section{Colour detemination}

Pomegranate juice colour was determined and measured in glass cells of $2 \mathrm{~mm}$ path length (CT-A22). A Minolta CR 2000 colorimeter (Minolta, Osaka, Japan) was used and results were expressed in the CIE $L^{*} a^{*} b^{*}$ system, and the mean values of lightness $\left(l^{*}\right)$, red/greenness $\left(a^{*}\right)$ and blue/yellowness $\left(b^{*}\right)$ coordinates for each juice were calculated. The objective colour was calculated as chromaticity or chroma $\left[C^{*}=\left(a^{* 2}+b^{*}\right)^{1 / 2}\right]$ and hue angle $\left[H^{\circ}=\tan ^{-1}\left(b^{*} / a^{*}\right)\right]$

\section{Total soluble solids and titratable acidity}

Total soluble solids (TSS) in the juice were measured using a digital refractometer (ATAGO RX-5000, calibrated using distilled water; Tokyo, Japan). Titratable acidity (TA) was measured by titrating an aliquot of juice with $0.1 \mathrm{~mol} \mathrm{~L}^{-1} \mathrm{NaOH}$ and expressed as $\mathrm{g}$ of citric acid $100 \mathrm{~mL}^{-1}$ of juice. The ratio TSS/TA, also known as the maturity index (MI), was also calculated.

\section{Antioxidant capacity and phytochemical analyses}

Total phenolic compounds and total anthocyanin content

Total phenolic compounds (TPC) were determined according to Singleton et al., ${ }^{17}$ using Folin-Ciocalteu reagent. Briefly, an aliquot of filtered juice was diluted with $0.4 \mathrm{~mL}$ of phosphate 
buffer $\left(50 \mathrm{mmol} \mathrm{L}^{-1}, \mathrm{pH}=7.8\right)$. Folin-Ciocalteu reagent $(2.5 \mathrm{~mL})$ was added and the content of the flask mixed thoroughly. After $8 \mathrm{~min}, \mathrm{Na}_{2} \mathrm{CO}_{3}$ solution $(10 \mathrm{~mL}, 10 \%$, w/ $/ \mathrm{v})$ was added and the samples were incubated in a water bath at $50^{\circ} \mathrm{C}$ for $5 \mathrm{~min}$. The resulting blue colour was measured spectrophotometrically at $760 \mathrm{~nm}$. The concentration of the total phenolic compounds in juice was determined by comparison with the absorbance of gallic acid at different concentrations. Results were expressed as $\mathrm{mg}$ of gallic acid (GA) $100 \mathrm{~mL}^{-1}$ of juice.

Total anthocyanin content (TAC) was determined by a $\mathrm{pH}$ differential method with two buffer systems, sodium acetate buffer, $\mathrm{pH} 4.5\left(0.4 \mathrm{~mol} \mathrm{~L}^{-1}\right)$ and potassium chloride buffer $\mathrm{pH}$ $\left.1.0\left(0.025 \mathrm{~mol} \mathrm{~L}^{-1}\right)\right)^{18}$ Pomegranate juice $(0.4 \mathrm{~mL})$ was mixed with $3.6 \mathrm{~mL}$ of corresponding buffers and read against water as blank at $510 \mathrm{~nm}$ and $700 \mathrm{~nm}$. The absorbance (A) was calculated as $A=\left(A_{510}-A_{700}\right)_{\mathrm{pH} 1.0}-\left(A_{510}-A_{700}\right)_{\mathrm{pH} 4.5}$. The total anthocyanin content was calculated by following the equation: $T A C=(A \times M W \times D F \times 100 / M A)$, where $A$ is the absorbance, $M W$ is the molecular weight (449.2), DF is the dilution factor (10), and MA is the molar absorptivity of cyaniding-3-glucoside (26.900). The result was expressed as mg cyaniding-3-glucoside (C3G) 100 $\mathrm{mL}^{-1}$ of pomegranate juice.

Measurement of antioxidant capacity

The ABTS - (2,2'-azino-bis(3-ethylbenzothiazoline-6-sulfonate) radical anion solution was generated as previously described by Egea et al..$^{19}$ Fifty microlitres of diluted $(1: 20)$ juice were mixed with $1.95 \mu \mathrm{L}$ of the radical solution to measure the antioxidant activity at $734 \mathrm{~nm}$ for a period of $6 \mathrm{~min}$. The decrease in absorbance at $734 \mathrm{~nm}$ for a period of $6 \mathrm{~min}$ after the addition of each compound was used to calculate the Trolox equivalent antioxidant capacity (TEAC). A calibration curve was prepared with different concentrations of Trolox (water-soluble analogous to vitamin E). The TEAC activity was calculated according to Egea et al., ${ }^{19}$ and the results were expressed as $\mathrm{mmol} \mathrm{L}^{-1}$ Trolox.

\section{Statistical analyses}

The design of the experiment was completely randomised with four replications, each replication consisting of three adjacent tree rows, each with 13 trees, which were very similar in appearance (leaf area, trunk cross-sectional area, height, ground shaded area, etc.). Plant water status, yield and marketable fruit quality measurements were taken on the inner tree of the central row of each replicate. Changes of PG fruit characteristics with time were studied in trees of the central row of each replicate adjacent to those for plant water status measurements. The other trees of each replication served as border trees. Data were analysed using Statgraphics Centurion XVI.I (Statpoint Technologies, Inc., Warrenton, VA, USA). Analyses of variance were performed and mean values were compared by an $\mathrm{LSD}_{0.05}$ test. Values for each replicate were averaged before the mean and the standard error of each treatment were calculated.

\section{RESULTS AND DISCUSSION}

\section{Plant water status}

During the experimental period, average daily maximum and minimum air temperatures were 27 and $14^{\circ} \mathrm{C}$, respectively. $\mathrm{VPD}_{\mathrm{m}}$ ranged from 0.24 to $2.59 \mathrm{kPa}$, and accumulated ETo was $451 \mathrm{~mm}$ Rainfall was very scarce, reaching only $51 \mathrm{~mm}$, which occured
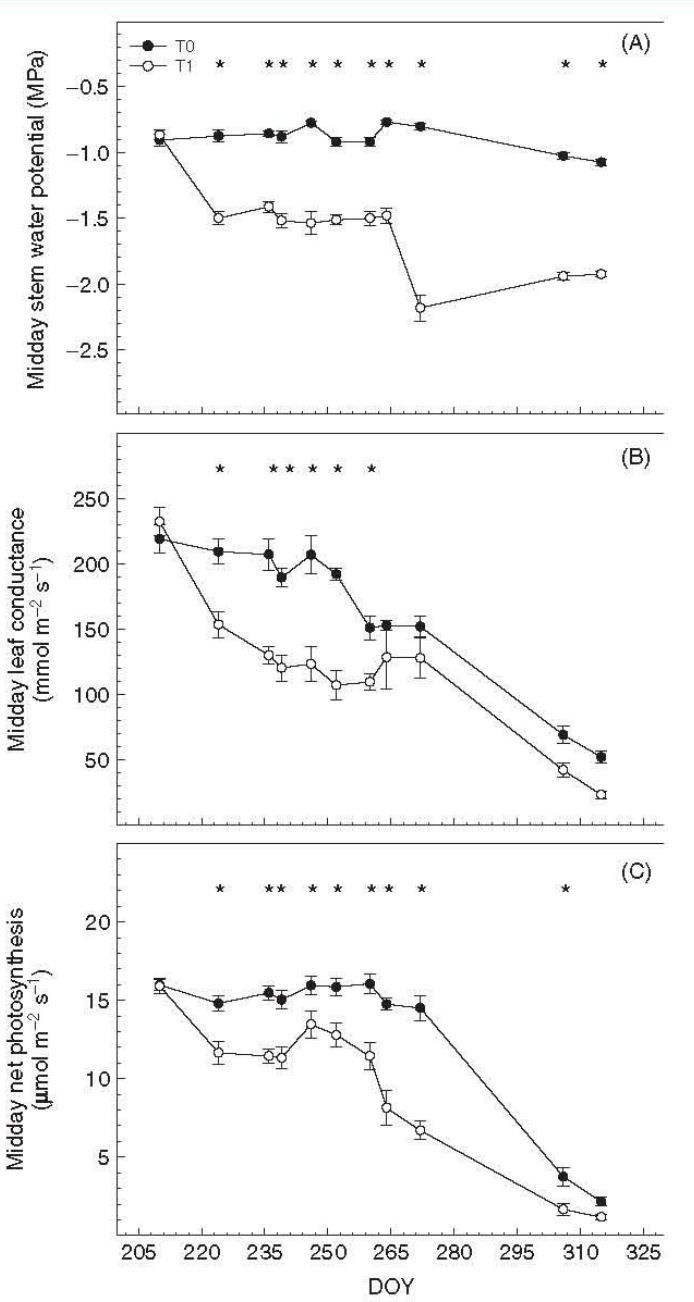

Figure 1. Midday stem water potential, $\Psi_{\text {stem }}$ (A), midday leaf conductance (B), and midday net photosynthesis (C) in TO (filled symbols) and T1 (unfilled (B), and midday net photosynthesis (C) in T0 (filled symbols) and T 1 (unfilled
symbols) plants during the experimental period. Bars on data points are \pm $\mathrm{SE}$ of the mean (not shown when smaller than symbols). Asterisks indicate statistically significant differences by least significant difference at the $5 \%$ level $\left(\mathrm{LSD}_{0.05}\right)$ range test. Each point is the mean of four values.

mainly in three daily episodes on DOY $214(7 \mathrm{~mm}), 232(20 \mathrm{~mm})$ and 291 (6 mm).

$\Psi_{\text {stem }}$ values in TO plants were high and near constant, ranging between -1.02 and $-0.76 \mathrm{MPa}$ (Fig. 1A). From DOY 224 onwards $T 1$ plants showed $\Psi_{\text {stem }}$ values lower than those of TO plants and minimum values were reached on DOY 272 $(-2.18 \mathrm{MPa}$ ) (Fig. 1A). In T0 and T1 plants, values of the midday leaf conductance presented an overall tendency to decrease as the season progressed (Fig. 1B). This behaviour was similar for values of midday net photosynthesis in T1 plants, whereas in TO plants the values were near constant from the beginning of the measurements period to DOY 272 (Fig. 1C). Significant differences between treatments were obtained in values for the midday leaf conductance and net photosynthesis from DOY 224 to 272 and from DOY 224 to 306 , respectively, reflecting an important degree of stomatal regulation in deficit irrigated (T1) plants (Fig. 1B and C). 
Table 1. Effect of irrigation treatments on total pomegranate fruit yield (TF) and number of harvested pomegranate fruits per tree (NF) at the three harvest times

\begin{tabular}{lccc} 
Harvest & Treatment & TF $\left(\mathrm{kg} \mathrm{tree}^{-1}\right)$ & NF \\
\hline I & T0 & $10.8^{\mathrm{a}}$ & $32.7^{\mathrm{a}}$ \\
& T1 & $8.81^{\mathrm{a}}$ & $37.0^{\mathrm{a}}$ \\
II & T0 & $38.4^{\mathrm{a}}$ & $138^{\mathrm{b}}$ \\
III & T1 & $39.3^{\mathrm{a}}$ & $167^{\mathrm{a}}$ \\
& T0 & 16.0 & 60.0 \\
I+ II+ III & T1 & - & - \\
& T0 & $65.2^{\mathrm{a}}$ & $231^{\mathrm{a}}$ \\
ANOVA & T1 & $48.1^{\mathrm{b}}$ & $204^{\mathrm{b}}$ \\
\hline
\end{tabular}

Means within a column for each harvest that do not have a common letter are significantly different by the $\mathrm{LSD}_{0.05}$ test

Asterisks indicate a statistically significant effect of harvest time.

The fact that plant water relations in TO plants were characterised by high $\Psi_{\text {stem }}$ and gas exchange (midday leaf conductance and net photosynthesis) values (Fig. 1) suggests that irrigation water requirements in control PG plants were attained. The rate of development of maximum water stress in T1 plants was very low because the $\Psi_{\text {stem }}$ values decreased by only around $0.005 \mathrm{MPa}$ $\mathrm{d}^{-1}$ (Fig. 1A) ${ }^{20}$ The fact that T0 and T1 plants showed important differences in $\Psi_{\text {stem }}$ values and the degree of stomatal regulation observed in T1 plants during the experimental period (Fig. 1B and C) showed that sustained deficit irrigation in these plants induced a severe water stress level.

\section{Yield, quality attributes and colour parameters}

Deficit irrigation led to a significant decrease in total fruit yield, a decrease in the number of total fruits per tree (Table 1) and mean fruit weight (TO fruits: $282.3 \mathrm{~g} \mathrm{fruit}^{-1}$ while T1 fruits: 235.8 $\mathrm{g}$ fruit $^{-1}$ ). Moreover, all T1 fruits were picked only at the first and second harvests, indicating that water deficit affects PG fruit ripening. At the first harvest, when only the first fruits in reaching marketable size were harvested, differences between treatments in these parameters were not significant. At the second harvest, deficit irrigated T1 plants increased the number of fruits harvested but the total yield was not statistically affected.

Results from total soluble solids (TSS), titratable acidity (TA) and the maturity index (MI) of the pomegranate juices from TO and T1 trees in their different ripening stages are shown in Table 2. TSS of $P G$ juices increased with the ripening stage, as expected, and were significantly $(P<0.05)$ higher in T1 fruits compared to T0. Values of TO ranged between 12.3 and $16.4^{\circ} \mathrm{Brix}$, while in the case of $\mathrm{T} 1$ the values oscillated between 13.6 and $18.3^{\circ}$ Brix (Table 2 ). In the case of TA, values ranged from 0.19 to $0.26 \mathrm{~g}$ citric acid $100 \mathrm{~g}^{-1}$; neither ripening stage nor irrigation treatment had significant effects on TA (Table 2). Similar behaviours were previously described by Mellisho et al. ${ }^{12}$ in fruits from the same PG cultivar. The MI has an evident influence on pomegranate taste and flavour. ${ }^{21}$ The MI values were significantly $(P<0.05)$ affected by both ripening stage and deficit irrigation. T0 showed values ranging from 47.8 to 80.9 , while values for $T 1$ fruits fluctuated between 68.6 and 81.3 . These values agreed quite well with those previously reported for sweet PG cultivars by Calín-Sánchez et al. ${ }^{15}$

The increment of the TSS and consequently the MI during the maturation of PG has been widely demonstrated ${ }^{22-24}$ and it is mainly attributed to the hydrolysis of starch, which increases as the ripening progresses. MI has been pointed out as a reliable indicator of the proper harvesting time of $\mathrm{PG}$ fruits, ${ }_{i}^{25}$ although there are differences among the cultivars and climatic conditions. ${ }^{22-24}$ Regarding deficit irrigation, the experimental finding that ' $\mathrm{MI}$ was significantly increased in deficit irrigation pomegranate fruits' has not been fully proved in previous studies. For instance, Mellisho et al..$^{12}$ and Mena et al..$^{13}$ reported similar trends, but differences were not high enough to be statistically significant.

Therefore, considering quality parameters studied above, it is worth mentioning that the proper maturation stage was achieved at DOY 287 for T1 (deficit irrigated) and DOY 295 for TO (control fruits); consequently an 8-day advance in the ripening of pomegranate fruits was achieved by using deficit irrigation, under the experimental conditions assayed in this study.

The effect of the irrigation treatment on the colour of pomegranate juice was statistically significant $(P<0.05)$. In general, T1 fruits had darker (lower values of $L^{*}$ ), more reddish (higher values of $a^{*}$ ), more bluish (lower values of $b^{*}$ ), and more intense garnet, combination of red and blue tones, colour than TO fruits (Table 2).

Similar results were previously reported by Mellisho et al. $!^{12}$ and Laribi et al. ${ }^{26}$ in data from arils and skin colour of 'Mollar de Elche' pomegranates, respectively. The last authors indicated that sustained deficit irrigation had low values of $L^{*}, b^{*}$ and Hue but high values of $a^{*}$; they concluded that as the pigment (anthocyanins) content increases, more light is absorbed and lower values of luminosity are recorded. ${ }^{27}$

On the other hand, the effects of ripening on the colour were clear and statistically significant, as expected (Table 2). The lightness, $L^{*}$, initially increased from DOY 236 until DOY 264 , and decreased hereafter. The green-red coordinate, $a^{*}$, continuously increased from the beginning until DOYs 307 and 301 in TO and T1 fruits, respectively. In contrast, the blue-yellow coordinate, $b^{*}$, continuously decreased from the first samplings until the end of the study. These temporal patters agreed very well with those found for TAC (Fig. 2B), in which a continuous increase was found, especially in the time interval from DOY 264 to DOY 287. This experimental finding fully agrees with the increase of juice pigmentation already described by Hernández et al. ${ }^{28}$ during pomegranate fruit ripening.

\section{Bioactive compounds and antioxidant capacity}

Results from total phenolic compounds (TPC), total anthocyanin content (TAC), and total antioxidant activity are shown in Fig. 2.

The TPC was significantly $(P<0.05)$ affected by the maturation stage but not by the deficit irrigation treatments. T0 showed values from 176 to $255 \mathrm{mg}$ of $\mathrm{GA} 100 \mathrm{~mL}^{-1}$, whereas $\mathrm{T} 1$ ranged between 184 and $260 \mathrm{mg}$ of $\mathrm{GA} 100 \mathrm{~mL}^{-1}$. As can be seen in Fig. 2A, there was only a slight increment in TPC until the ripening of the PGs reached DOY 295 for both treatments but from this moment until the last harvest time the increment showed a sharper slope. In general, an increase of the TPC is initially expected but it is not always found. Several authors have experimentally found decreases in the TPC as ripeness progresses and the decrease has been explained by the oxidation of polyphenols due to the presence of the enzyme polyphenol oxidase: ${ }_{i}^{23-25}$ all these authors studied different pomegranate cultivars. However, Mellisho et al..$^{12}$ also reported an increment of $25 \%$ in 'Mollar de Elche' fruits. Consequently, the different behaviours of the TPC could be explained, at least in part, by genetic factors. 


\begin{tabular}{|c|c|c|c|c|c|c|c|c|c|}
\hline \multirow[b]{2}{*}{ Parameter } & \multirow[b]{2}{*}{ Treatment } & \multicolumn{8}{|c|}{ Day of the year (DOY) } \\
\hline & & 236 & 252 & 264 & 287 , harvest I & 295 , harvest II & 301 & 307 , harvest III & 315 \\
\hline \multirow[t]{2}{*}{$\operatorname{TSS}\left({ }^{\circ}\right.$ Brix $)$} & TO & $12.3^{\mathrm{a}}$ & $14.3^{b}$ & $14.8^{\mathrm{b}}$ & $16.4^{\mathrm{a}}$ & $16.2^{\mathrm{b}}$ & $16.1^{\mathrm{b}}$ & $16.2^{b}$ & $16.4^{b}$ \\
\hline & $\mathrm{T} 1$ & $13.6^{\mathrm{a}}$ & $15.7^{\mathrm{a}}$ & $16.3^{\mathrm{a}}$ & $17.2^{\mathrm{a}}$ & $17.6^{\mathrm{a}}$ & $17.6^{\mathrm{a}}$ & $17.9^{\mathrm{a}}$ & $18.3^{\mathrm{a}}$ \\
\hline \multirow[t]{2}{*}{ MI (TSS/TA) } & T0 & $47.8^{\mathrm{a}}$ & $75.9^{\mathrm{a}}$ & $74.8^{b}$ & $62.9^{b}$ & $80.9^{\mathrm{a}}$ & $70.1^{\mathrm{a}}$ & $65.1^{\mathrm{b}}$ & $64.2^{\mathrm{b}}$ \\
\hline & $\mathrm{T} 1$ & $68.6^{\mathrm{a}}$ & $77.0^{\mathrm{a}}$ & $82.4^{\mathrm{a}}$ & $81.3^{\mathrm{a}}$ & $76.7^{\mathrm{a}}$ & $71.3^{\mathrm{a}}$ & $72.0^{\mathrm{a}}$ & $69.9^{\mathrm{a}}$ \\
\hline \multirow[t]{2}{*}{$L^{*}$} & TO & $67.2^{\mathrm{a}}$ & $72.3^{a}$ & $73.9^{\mathrm{a}}$ & $70.5^{\mathrm{a}}$ & $72.3^{\mathrm{a}}$ & $68.8^{\mathrm{a}}$ & $63.8^{\mathrm{a}}$ & $65.3^{a}$ \\
\hline & $\mathrm{T} 1$ & $67.7^{a}$ & $70.3^{b}$ & $74.2^{\mathrm{a}}$ & $60.8^{b}$ & $59.9^{b}$ & $54.3^{b}$ & $52.7^{b}$ & $48.0^{b}$ \\
\hline$a^{*}$ & TO & $-6.2^{\mathrm{a}}$ & $-2.9^{\mathrm{a}}$ & $6.1^{\mathrm{b}}$ & $29.8^{b}$ & $26.9^{b}$ & $27.8^{\mathrm{b}}$ & $35.1^{\mathrm{b}}$ & $28.0^{b}$ \\
\hline$C^{*}$ & $\mathrm{~T} 1$ & $45.5^{\mathrm{a}}$ & $42.8^{b}$ & $44.9^{\mathrm{a}}$ & $51.1^{\mathrm{a}}$ & $52.0^{\mathrm{a}}$ & $50.9^{\mathrm{a}}$ & $49.5^{\mathrm{a}}$ & $45.9^{\mathrm{a}}$ \\
\hline \multirow[t]{2}{*}{$H^{\circ}$} & T0 & $98.1^{\mathrm{a}}$ & $93.6^{a}$ & $82.1^{\mathrm{a}}$ & $50.9^{\mathrm{a}}$ & $53.0^{\mathrm{a}}$ & $50.7^{a}$ & $38.0^{\mathrm{a}}$ & $43.9^{\mathrm{a}}$ \\
\hline & $\mathrm{T} 1$ & $102^{\mathrm{a}}$ & $87.1^{\mathrm{a}}$ & $73.9^{b}$ & $37.6^{\mathrm{a}}$ & $32.7^{b}$ & $27.2^{b}$ & $25.6^{\mathrm{b}}$ & $24.0^{b}$ \\
\hline
\end{tabular}

Regarding the irrigation treatment effect, no significant differences were observed (Fig. 2A) between T0 and T1 fruits, as previously stated for similar deficit irrigation treatments by Mellisho et al..$^{12}$ Only the picking time of DOY 307 showed differences, due to the fact that the increase in TPC was already advanced 1 week in T1 compared to To fruits.

TAC increased considerably for both irrigation treatments along the ripening process and its values ranged from 0.40 to $12.6 \mathrm{mg}$ C3G $100 \mathrm{~mL}^{-1}$ in T0 fruits, while for T1 fruits TAC ranged from 0.4 to $12.5 \mathrm{mg} \mathrm{C} 3 G 100 \mathrm{~mL}^{-1}$ (Fig. 2B). The highest content of anthocyanins was reached at DOYs 307 and 315 . These final values agreed quite well with those previously reported by Mellisho et al., ${ }^{12}$ Mena et al. ${ }^{13}$ and Laribi et al. ${ }^{26}$ Other researchers also have described the same pattern of TAC but in different pomegranate cultivars. ${ }^{25}$ PG fruits showed a low increment in the first stage of fruit ripening (up to DOY 264), followed by a very rapid increment at the middle stages (up to DOY 295); however, no increment in juice pigmentation was detected in the late stages of fruit maturation. ${ }^{22,29}$ The red colour of pomegranate juice is due to the presence of anthocyanins, ${ }^{30}$ mainly cyanidin 3-glucoside, cyanidin 3,5-diglucoside, delphinidin 3-glucoside and delphinidin 3,5-diglucoside. ${ }^{26,31}$ A positive correlation between TAC and the values of the green-red coordinate, $a^{*}$, was found $\left(R^{2}=0.7719\right)$, proving similar trends in both parameters and the high relationship between them.

Regarding TAC and deficit irrigation, not significant difference $(P<0.05)$ were observed among the treatments (TO and T1). Mena et al. ${ }^{13}$ reported similar trend for control fruits and trees with moderate deficit irrigation.

TEAC was highly influenced by the ripening stage and only slightly by the deficit irrigation treatment. At the first harvest time (DOY 236), the TEAC values for TO and T1 were 30.8 and 22.9 mmol $\mathrm{L}^{-1}$ Trolox, respectively. In the next two harvests, there was an important decrease of TEAC down to 17.9 and $16.6 \mathrm{mmol}$ $\mathrm{L}^{-1}$ Trolox for T0 at DOY 252 and for T1 at DOY 264 , respectively
(Fig. 2C). This experimental trend was in concordancewith previous researches indicating that a decrease in the antioxidant capacity was associated with a decrease of TPC. ${ }^{32}$ However, when the fruits reached DOY 264, the TEAC values of the PG juices started to drastically increase until the DOY 295; from this stage TEAC remained constant, with no significant differences being found between TO and T1 PG juices. The highest values for TO and T1 were around 31 and $34 \mathrm{mmol} \mathrm{L}^{-1}$ Trolox. These values agreed with those previously reported by Mena et al. ${ }^{13}$ The increment of the TEAC from immature PG fruits until commercial mature fruits could be related to the simultaneous increases of both the TPC and TAC. In the current experiment and despite the fact that anthocyanins are not always considered as major contributors to the antioxidant capacity of PG juices, ${ }^{12,13,33}$ it seems that both anthocyanins and phenolic compounds had a clear contribution to the antioxidant capacity of PG fruits.

With regard to the irrigation treatment effect on TEAC values, no significant differences were found except at some of the initial fruit samplings; however, when the pomegranate fruits reach their marketable conditions, no effect was seen, as previously reported. ${ }^{12,13}$ Thus, it can be confirmed that, regarding bioactive compositions of PGs, deficit irrigation provides PG fruits with similar bioactive quality to control fruits. It can be stated that pomegranate responds to deficit irrigation in a different way to other fruits (e.g. jujube fruits), which clearly increase their content of bioactive compounds. ${ }^{34}$

However, and from an industrial point of view, perhaps the most important conclusion that can be reached is that if a pomegranate juice or other pomegranate-based products are to be manufactured it is crucial to wait for fruits to be at the end of the harvesting period. The use of late-flowering fruits will ensure simultaneous high contents of TPC and TAC, as well as high TEAC values. Again the use of deficit irrigation strategies will advance the availability of these fruits by approximately 1 week. The exact 

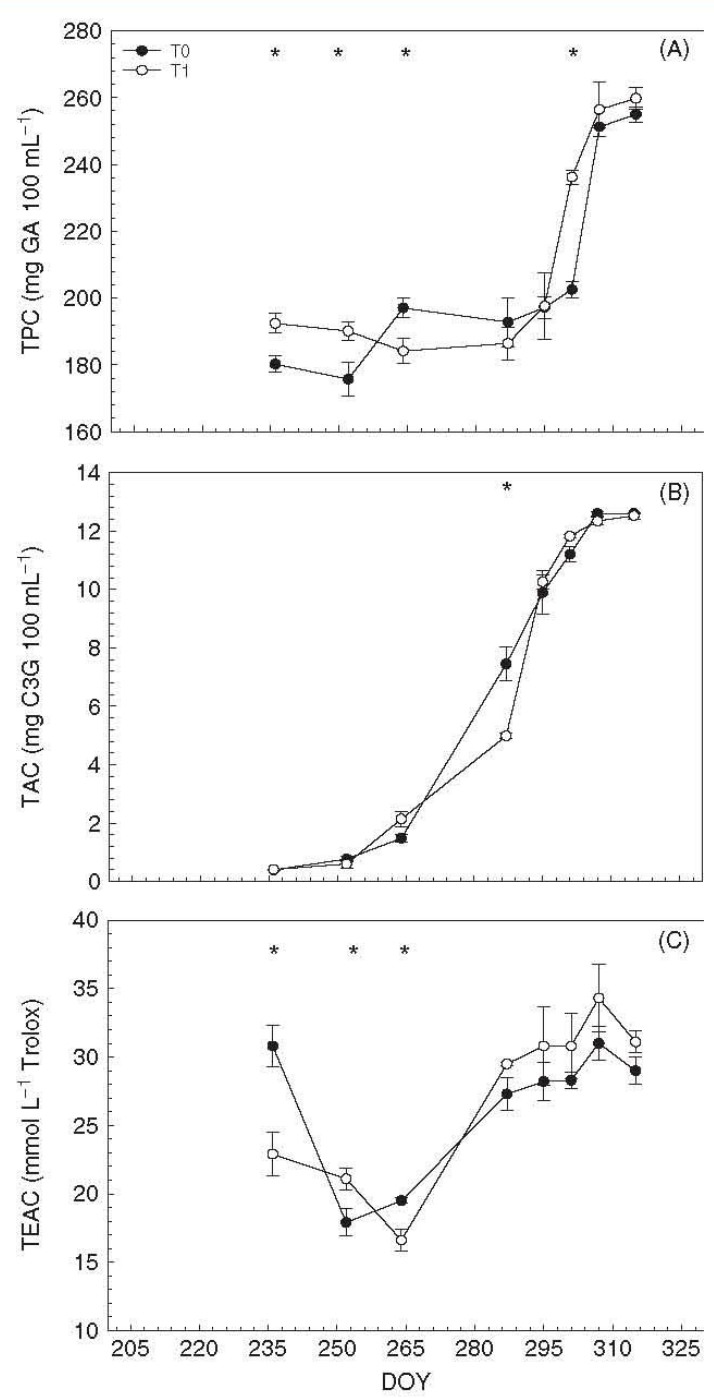

Figure 2. Total phenolic compounds, TPC (A), total anthocyanin content, TAC (B) and Trolox equivalent antioxidant capacity, TEAC (C) in TO (filled symbols) and T1 (unfilled symbols) plants during the experimental period. Bars on data points are \pm SE of the mean (not shown when smaller than symbols). Asterisks indicate statistically significant differences by least significant difference at the $5 \%$ level $\left(\mathrm{LSD}_{0.05}\right)$ range test. Each point is the mean of four values.

dates should be assayed locally, because environmental, plant material and cultural practices will have important effects.

\section{CONCLUSIONS}

In the particular case of pomegranate, deficit irrigation significantly reduced the total yield per tree, the number of fruits per tree and the size of the fruits. However, deficit irrigation had an interesting effect in that it advanced the optimal harvest time by about 7-8 days. Additionally, it is obvious that deficit irrigation will save a significant amount of water, a key aspect in regions worldwide that have limited water resources. This is important because high quality fruits will be available sooner for national and international markets, as normal cultivar are transformed into early ones. Another important finding is that deficit irrigation did not result in fruits with a higher content of bioactive compounds compared to control fruits. The optimal harvest time for fruits intended for the manufacture of juices rich in bioactive compounds (phenolic compounds and anthocyanins) should not be the same as that for products intended for fresh consumption. A delay of approximately 14 days between the harvest times for the fresh fruit and the fruit intended for juice is recommended. This recommendation is based on the fact that fruits harvested for juice manufacture were from late flowerings, which were smaller in size but have very high contents of bioactive compounds. In some cases, farmers do not harvest these fruits because of the high labour costs involved in picking; however, and after knowing the high functional quality of these fruits, it will be worth harvesting them because of their high additional value. Therefore, a waste material could be transformed to a product of high value and of interest for the juice industry.

\section{REFERENCES}

1 Melgarejo P, Salazar DM and Artés F, Organic acids and sugars composition of harvested pomegranate fruits. Eur Food Res Technol 211:185-190(2000).

2 Basu $A$ and Penugonda $K$, Pomegranate juice: $A$ heart-healthy fruit juice. Nutr Rev 67:49-56 (2009).

3 Malik A, Afaq F, Sarfaraz S, Adhami V, Syed D and Mukhtar $H_{\text {, }}$ Pomegranate fruit juice for chemoprevention and chemotherapy of prostate cancer. Proc Nat/Acad SCi USA 102:14813-14818(2005).

4 Aviram $M$ and Dornfeld $L$, Pomegranate juice consumption inhibits serum angiotensin converting enzyme activity and reduces systolic blood pressure. Atherosclerosis 158:195-198(2001).

5 Sumner MD, Elliott-Eller M, Weidner G, Daubenmier JJ, Chew MH and Marlin R, Effects of pomegranate juice consumption on myocardial perfusion in patients with coronary heart disease. Am J Cardiof 96:810-814(2005).

6 Stover E and Mercure EW, The pomegranate: A new look at the fruit of paradise. HortScience 42:1088-1092 (2007).

7 Holland D, Hatib K and Bar-Yàakov I, Pomegranate: botany, horticulture, breeding. Hort Rev 35:127-191 (2009).

8 MAGRAMA, Ministerio de Agricultura, Alimentación y Medio Ambiente. Anuario de Estadística Agraria 2012 Available: http://Www. magrama.gob.es/estadistica/pags/anuario/2012/AE_2012_Completo.pdf [30 September 2013]

9 Rodríguez $\mathrm{P}$, Mellisho $\mathrm{CD}$, Conejero W, Ortuño MF, Cruz ZN, Galindo $A$, et al., Plant water relations of leaves of pomegranate trees under different irrigation conditions. Environ Exp Bot 77:19-24 (2012).

10 Aseri GK, Jain N, Panwar J, Rao AV and Meghwal PR, Biofertilizers improve plant growth, fruit yield, nutrition, metabolism and rhizosphere enzyme activities of pomegranate (Punica granatum L.) in Indian Thar Desert. Sci Hort 117:130-135 (2008).

11 Sarkhosh A, Zamani Z, Fatahi R and Ebadi A, RAPD markers reveal polymorphismamong some Iranian pomegranate (Punicagranatum L.) genotypes. Sci Hort 111:24-29 (2006).

12 Mellisho CD, Egea I, Galindo A, Conejero W, Rodríguez P, Rodríguez J, et al., Pomegranate (Punica granatum L) fruit response to different deficit irrigation conditions. Agric WaterManage 114:30-36 (2012).

13 Mena P, Galindo A, Collado-González J, Ondoño S, García-Viguera C, Ferreres F, et al., Sustained deficit irrigation affects the colour and phytochemical characteristics of pomegranate juice.J SciFoodAgric 93:1922-1927 (2013).

14 Koppel K, Chambers IV E, Vázquez-Araújo L, Timberg L, CarbonellBarrachina AA and Suwonsichon S, Cross-country comparison of pomegranate juice acceptance in Estonia, Spain, Thailand, and United States. Food Qual Prefer 31:116-123 (2014).

15 Calín-Sánchez A, Martínez JJ, Vázquez-Araújo L, Burló F, Melgarejo $\mathrm{P}$ and Carbonell-Barrachina AA, Volatile composition and sensory quality of Spanish pomegranates (Punica granatum L.). I Sci food Agric 91:586-592 (2011). 
16 Allen RG, Pereira RS, Raes D and Smith $M_{1}$ Crop Evapotranspiration - Guidelines for Computing Crop Water Requirements, v. 56, FAO Irrigation and Drainage 56. Food and Agriculture Organization Rome (1998).

17 Singleton VL, Orthofer R and Lamuela-Raventos RM, Analysis of total phenols and other oxidation substrates and antioxidants by mean of Folin-Ciocalteu reagent. Methods Enzymol 299:152-178 (1999).

18 Giusti MM, Rodriguez-Saona LE and Wrolstad RE, Molar absorptivity and color characterisque of acylated and non-acylated pelargodinebased anthocyanins. J Agric Food Chem 47:4631-4637 (1999).

19 Egea MI, Sánchez-Bel P, Marínez-Madrid MC, Flores FB and Romojaro F The effect of beta ionization on the antioxidant potential of 'Búlida' apricot and its relationship with quality. Post Biol Technol 46:63-70 (2007).

20 Hale MG and Orcutt DM, The Physiology of Plants Under Stress. Wiley, New York (1987).

21 Tehranifara A, Zareia M, Nematia Z, Esfandiyaria B and Vazifeshenas $M R$, Investigation of physico-chemical properties and antioxidant activity of twenty Iranian pomegranate (Punica granatum L) cultivars. Sci Hort 126:180-185 (2010).

22 Shwartz E, Glazer I, Bar-Ya'akov I, Matityahu I, Bar-llan I, Holland D, et al., Changes in chemical constituents during the maturation and ripening of two commercially important pomegranate accessions. Food Chem 115:965-973 (2009).

23 Kulkarni AP and Aradhya SM, Chemical changes and antioxidan activity in pomegranate arils during fruit development. Food Chem 93:319-324 (2005).

24 Al-Maiman SA and Ahmad D, Changes in physical and chemical properties during pomegranate (Punica granatum L.) fruit maturation. Food Chem 76:437-441 (2002).

25 Fawole OA and Opara UL, Changes in physical properties, chemical and elemental composition and antioxidant capacity of pomegranate (cv. Ruby) fruit at five maturity stages. Sci Hort 150:37-46 (2013).
26 Laribi Al, Palou L, Intrigliolo DS, Nortes PA, Rojas-Argudo C, Taberne $\checkmark$, et al. Effect of sustained and regulated deficit irrigation on fruit quality of pomegranate cv. 'Mollar de Elche' at havest and during cold storage. Agric Water Manage 125:61-70 (2013).

27 Dixon J, Temperature and atmosphere composition influence on colour change of apples. MS thesis, Massey University, Palmerston North, New Zealand (1993).

28 Hernández F. Melgarejo P. Tomás-Barberán FA and Artés F, Evolution of juice anthocyanins during ripening of new selected pomegranate (Punica granatum) clones. Eur Food Res Technol 210:39-42 (1999).

29 Zarei $M$, Azizi $M$ and Bashir-Sadr Z, Evaluation of physicochemical characteristics of pomegranate (Punica granatum L.) fruit during ripening. Fruits 66:121-129(2011).

30 Shulman $\mathrm{Y}$, Fainberstein $\mathrm{L}$ and Lavee $\mathrm{S}$, Pomegranate fruit development and maturation. $j$ Hort SCi Biotechnol 59:265-274 (1984).

31 Mena P, Garcia-Viguera C, Navarro-Rico J, Moreno DA, Bartual J, Saura D, et al., Phytochemical characterization for industrial use of pomegranate (Punica granatum L.) cultivars grown in Spain. J SC Food Agric 91:1893-1906.

32 Fischer UA, Carle R and Kammerer DR, Identification and quantification of phenolic compounds from pomegranate (Punica granatum $\mathrm{L}$. peel, mesocarp, aril and differently produced juices by HPLC DAD-ESI/MSn. Food Chem 127:807-821 (2011).

33 Borochov-Neori H, Judeinstein S, Tripler E, Harari M, Greenberg A Shomer I, et al, Seasonal and cultivar variations in antioxidant and sensory quality of pomegranate (Punica granatum L.) fruit. $J$ Foo Comp Anal 22:189-195 (2009).

34 Collado-González J, Cruz ZN, Rodríguez P, Galindo A, Díaz-Baños FG, García de la Torre J, et al., Effect of water deficit and domestic storage on the procyanidin profile, size, and aggregation process in pear-jujube (Z. jujube) fruits. j Agric Food Chem 61:6187-6197 (2013). 
7. Conclusions 
1. Pomegranate plants confront water stress by developing stress avoidance and stress tolerance mechanisms. These mechanisms were complementary and took place gradually.

2. Stress avoidance mechanisms were mainly based in a leaf conductance decrease in order to control water loss via transpiration and avoid leaf turgor loss.

3. When maximum water deficit levels were developed, stress tolerance mechanisms were developed as active osmotic adjustment, which could have contributed to the maintenance of leaf turgor. Furthermore, other drought tolerance characteristics were observed in pomegranate including high relative apoplastic water content.

4. During the end of fruit growth and ripening period, water could enter the pomegranate fruits via the phloem rather than via the xylem and fruits were sensitive to water deficit. In this sense, during very severe water stress leaves were able to maintain leaf turgor but fruit turgor was lost, inducing the reduced expansion of fruits.

5. When rainfall affected previously water stressed pomegranate plants an asymmetric increase in fruit turgor pressure took place, because aril turgor increased to a much greater extent than peel turgor. This increase in aril pressure would put pressure on the peel and make it susceptible to cracking.

6. Maximum daily trunk shrinkage (MDS) was a reliable plant-based water stress indicator in adult pomegranate trees. In addition, the fact that trunk diameter sensors used in the experiments did not have to be repositioned, together with other operational advantages over discretely measured indicators, such as the low labour costs involved and the possibility of connection to remotely operated 
irrigation controllers, confirm that MDS is a suitable plant-based indicator for precise irrigation scheduling practices.

7. MDS exponential reference equations can be obtained by pooling data across several seasons for mean daily air temperature. MDS first-order reference equations can be also obtained by pooling data across several seasons for crop reference evapotranspiration, mean daily air vapour pressure deficit, mean daily air temperature and solar radiation, but these reference equations should be used only within a certain range of values. So, automated MDS measurements can be normalized to non-limiting water conditions by locally derived empirical relationships with meteorological variables.

8. Fruits from late flowerings, which traditionally are considered a waste material for being smaller than those for fresh consumption, are ideal for pomegranate juice industry due to their very high contents of bioactive compounds (phenolic compounds and anthocyanins).

9. During the ripening phase pomegranate fruits change in order to show a peel with higher luminosity and red saturation. Also, aril colour changes to exhibit a more perceptible red colour as a consequence of the increasing total anthocyanin content. However, neither the red colour intensity of the arils nor its total phenolic compounds content was correlated with the juice antioxidant capacity.

10. Fruits from plants under sustained moderate water stress level showed a decrease in fruit growth, inducing a lower final fruit size and lower total yield, accompanied by changes in colour and fruit chemical characteristics, which reflected earlier ripening. In contrast, a more pronounced water stress level only during the second half of fruit growth phase was more critical for fruit size than for their 
chemical characteristics, probably because under this situation carbon assimilation should be allocated to the synthesis of primary metabolites, which did not exceeded the amount used for fruit growth to the detriment of the synthesis of carbon-based secondary metabolites.

11. Pomegranate juice from trees under moderate or severe sustained deficit irrigation was of lower quality and less healthful than that from fruits without water stress, because of a reduction in irrigation provides a dramatic decrease in levels of phenolic compounds, especially anthocyanins and punicalagins, and hence a lower visual attraction of the resulting fruit juice owing to its weak red colour. 
8. Appendix 


\section{Quality indexes of each publication}

Data from the 2013 edition of Journal Citation Reports ${ }^{\circledR}$

Information updated on 11 February 2015

Rodríguez, P., Mellisho, C.D., Conejero, W., Ortuño, M.F., Cruz, Z.N., Galindo, A., Torrecillas, A. 2012. Plant water relations of leaves of pomegranate trees under different irrigation conditions. Environmental and Experimental Botany 77: 19-24.

Publisher: Pergamon-Elsevier Science Ltd, The Boulevard, Langford Lane, Kidlington, Oxford OX5 1GB, England

ISSN: 0098-8472

Research Domain: Plant Sciences, Environmental Sciences \& Ecology

$\begin{array}{ccccc}\begin{array}{c}\mathrm{JCR}^{\circledR} \\ \text { Category }\end{array} & \begin{array}{c}\text { Quartile in } \\ \text { Category }\end{array} & \text { Rank } & \begin{array}{c}\text { Impact } \\ \text { factor }\end{array} & \begin{array}{c}\text { 5-year impact } \\ \text { factor }\end{array} \\ \begin{array}{c}\text { Plant } \\ \text { Sciences }\end{array} & \text { Q1 } & 36 / 199 & 3.003 & 3.529\end{array}$

Galindo, A., Rodríguez, P., Collado-González, J., Cruz, Z.N., Torrecillas, E., Ondoño, S., Corell, M., Moriana, A., Torrecillas, A. 2014. Rainfall intensifies fruit peel cracking in water stressed pomegranate trees. Agricultural and Forest Meteorology 194: 29-35

Publisher: Elsevier Science BV, PO Box 211, 1000 AE Amsterdam, Netherlands

ISSN: 0168-1923

Research Domain: Agriculture, Forestry, Meteorology \& Atmospheric Sciences

$\begin{array}{ccccc}\begin{array}{c}\mathrm{JCR}^{\circledR} \\ \text { Category }\end{array} & \begin{array}{c}\text { Quartile in } \\ \text { Category }\end{array} & \text { Rank } & \begin{array}{c}\text { Impact } \\ \text { factor }\end{array} & \begin{array}{c}\text { 5-year impact } \\ \text { factor }\end{array} \\ \text { Forestry } & \mathbf{Q 1} & 1 / 64 & 3.894 & 4.214\end{array}$


Galindo, A., Rodríguez, P., Mellisho, C.D., Torrecillas, E., Moriana, A., Cruz, Z.N., Conejero, W., Moreno, F., Torrecillas, A. 2013. Assessment of discretely measured indicators and maximum daily trunk shrinkage for detecting water stress in pomegranate trees. Agricultural and Forest Meteorology 180: 58-65.

Publisher: Elsevier Science BV, PO Box 211, 1000 AE Amsterdam, Netherlands

ISSN: 0168-1923

Research Domain: Agriculture, Forestry, Meteorology \& Atmospheric Sciences

$\begin{array}{ccccc}\begin{array}{c}\mathrm{JCR}^{\circledR} \\ \text { Category }\end{array} & \begin{array}{c}\text { Quartile in } \\ \text { Category }\end{array} & \text { Rank } & \begin{array}{c}\text { Impact } \\ \text { factor }\end{array} & \begin{array}{c}\text { 5-year impact } \\ \text { factor }\end{array} \\ \text { Forestry } & \mathbf{Q 1} & 1 / 64 & 3.894 & 4.214\end{array}$

Mellisho, C.D., Egea, I., Galindo, A., Conejero, W., Rodríguez, P., Rodríguez, J., Romojaro, F., Torrecillas, A. 2012. Pomegranate (Punica granatum L.) fruit response to different deficit irrigation conditions. Agricultural Water Management 114: 30-36.

Publisher: Elsevier Science BV, PO BOX 211, 1000 AE Amsterdam, Netherland

ISSN: $0378-3774$

Research Domain: Agriculture, Water Resources

$\begin{array}{ccccc}\begin{array}{c}\mathrm{JCR}^{\circledR} \\ \text { Category }\end{array} & \begin{array}{c}\text { Quartile in } \\ \text { Category }\end{array} & \text { Rank } & \begin{array}{c}\text { Impact } \\ \text { factor }\end{array} & \begin{array}{c}\text { 5-year impact } \\ \text { factor }\end{array} \\ \begin{array}{c}\text { Water } \\ \text { Resources }\end{array} & \mathbf{Q 1} & 18 / 81 & 2.333 & 2.822\end{array}$


Mena, P., Galindo, A., Collado-González, J., Ondoño, S., GarcíaViguera, C., Ferreres, F., Torrecillas, A., Gil-Izquierdo, A. 2013. Sustained deficit irrigation affects the colour and phytochemical characteristics of pomegranate juice. Journal of the Science of Food and Agriculture 93: 1922-1927.

Publisher: WILEY-BLACKWELL, 111 RIVER ST, HOBOKEN 07030 5774, NJ USA

ISSN: $0022-5142$

Research Domain: Agriculture, Chemistry, Food Science \& Technology

$\begin{array}{ccccc}\mathrm{JCR}^{\circledR} \text { Category } & \begin{array}{c}\text { Quartile in } \\ \text { Category }\end{array} & \text { Rank } & \begin{array}{c}\text { Impact } \\ \text { factor }\end{array} & \begin{array}{c}\text { 5-year impact } \\ \text { factor }\end{array} \\ \begin{array}{c}\text { Agriculture, } \\ \text { Multidisciplinary }\end{array} & \mathbf{Q 1} & 7 / 56 & 1.879 & 1.983\end{array}$

Galindo, A., Calín-Sánchez, A., Collado-González, J., Ondoño, S., Hernández, F., Torrecillas, A., Carbonell-Barrachina, A. 2014. Phytochemical and quality attributes of pomegranate fruits for juice consumption as affected by ripening stage and deficit irrigation. Journal of the Science of Food and Agriculture 94: 2259-2265.

Publisher: WILEY-BLACKWELL, 111 RIVER ST, HOBOKEN 07030-

$$
5774 \text {, NJ USA }
$$

ISSN: $0022-5142$

Research Domain: Agriculture, Chemistry, Food Science \& Technology

$\begin{array}{ccccc}\text { JCR }^{\circledR} \text { Category } & \begin{array}{c}\text { Quartile in } \\ \text { Category }\end{array} & \text { Rank } & \begin{array}{c}\text { Impact } \\ \text { factor }\end{array} & \begin{array}{c}\text { 5-year impact } \\ \text { factor }\end{array} \\ \begin{array}{c}\text { Agriculture, } \\ \text { Multidisciplinary }\end{array} & \mathbf{Q 1} & 7 / 56 & 1.879 & 1.983\end{array}$

